Prepared in cooperation with the U.S. Environmental Protection Agency as part of the Great Lakes Restoration Initiative

\title{
Geology, Hydrology, Water Quality, and Potential for Interbasin Invasive-Species Spread by Way of the Groundwater Pathway Near Lemont, Illinois
}

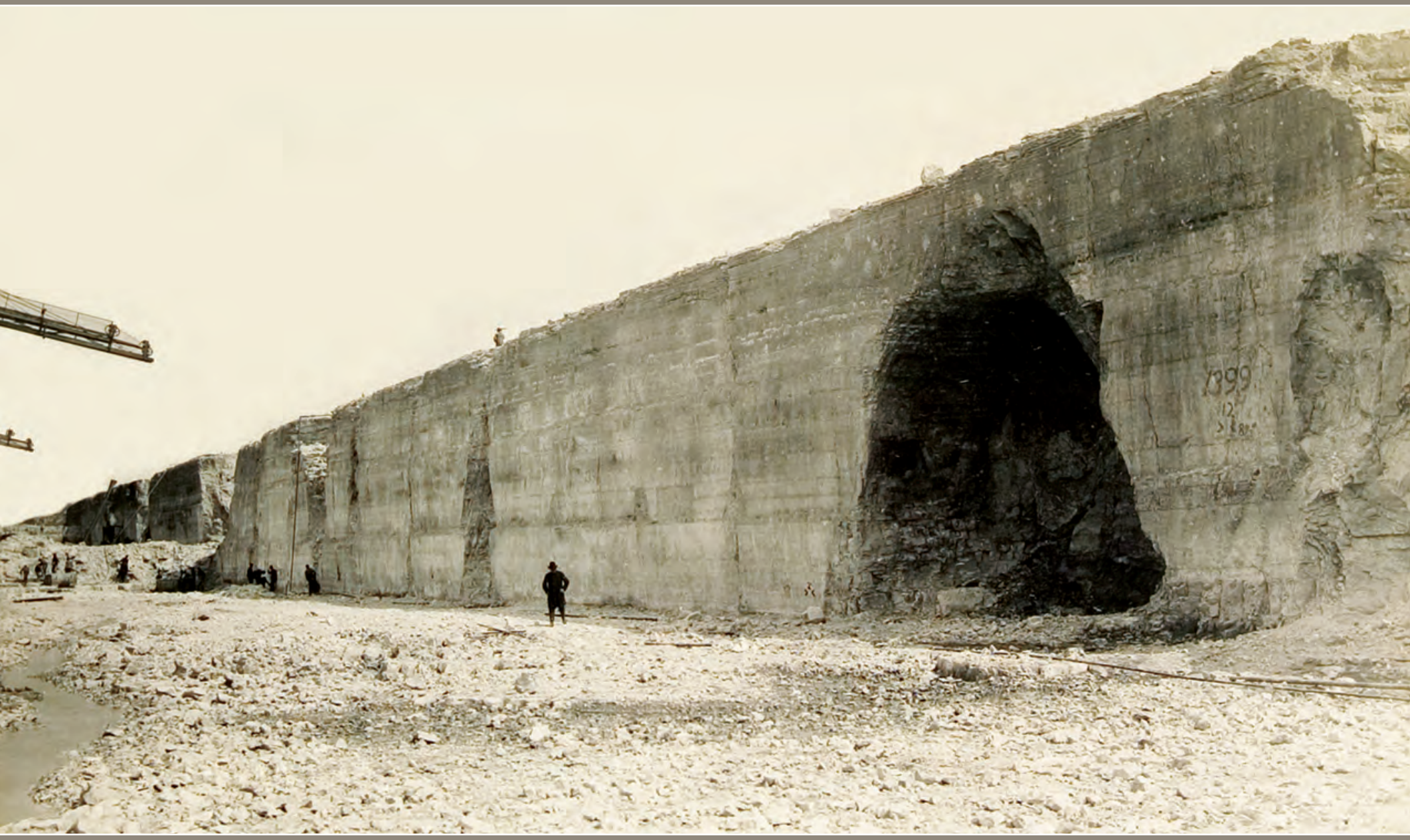

Scientific Investigations Report 2016-5095

U.S. Department of the Interior U.S. Geological Survey 
Cover. View of construction along wall of Chicago Sanitary and Ship Canal south of Romeo Road, 1892-1900; note clay-filled karst feature in foreground. (Print ICHi-65121, photograph by Chicago Sanitary, courtesy of Chicago History Museum.) 


\section{Geology, Hydrology, Water Quality, and Potential for Interbasin Invasive-Species Spread by Way of the Groundwater Pathway Near Lemont, Illinois}

By Robert T. Kay, Patrick C. Mills, and P. Ryan Jackson

Prepared in cooperation with the U.S. Environmental Protection Agency as part of the Great Lakes Restoration Initiative

Scientific Investigations Report 2016-5095 


\title{
U.S. Department of the Interior SALLY JEWELL, Secretary
}

\section{U.S. Geological Survey Suzette M. Kimball, Director}

\author{
U.S. Geological Survey, Reston, Virginia: 2016
}

For more information on the USGS - the Federal source for science about the Earth, its natural and living resources, natural hazards, and the environment, visit http://www.usgs.gov or call 1-888-ASK-USGS

For an overview of USGS information products, including maps, imagery, and publications, visit http://store.usgs.gov

To order this and other USGS information products, visit http://store.usgs.gov

Any use of trade, product, or firm names is for descriptive purposes only and does not imply endorsement by the U.S. Government.

Although this report is in the public domain, permission must be secured from the individual copyright owners to reproduce any copyrighted materials contained within this report.

Suggested citation:

Kay, R.T., Mills, P.C., and Jackson, P.R., 2016, Geology, hydrology, water quality, and potential for interbasin invasive-species spread by way of the groundwater pathway near Lemont, Illinois: U.S. Geological Survey Scientific Investigations Report 2016-5095, 91 p., http://dx.doi.org/10.3133/sir20165095.

ISSN 2328-0328 (online) 


\section{Acknowledgments}

The authors thank Andrew Teeple of the Texas Water Science Center of the U.S. Geological Survey for performing the surface geophysical surveys. The authors thank Donald Mikulic of the Illinois State Geological Survey for his guidance in the characterization of the dolomite deposits. The authors thank Jim Ursic of the U.S. Environmental Protection Agency for performing borehole and surface geophysical surveys. Finally, the authors thank the Metropolitan Water Reclamation District of Greater Chicago for providing site access and for the use of their data. 



\section{Contents}

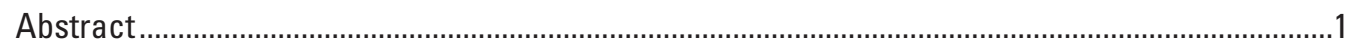

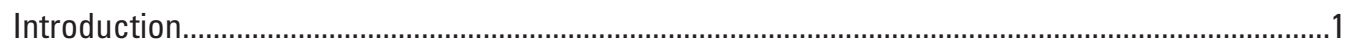

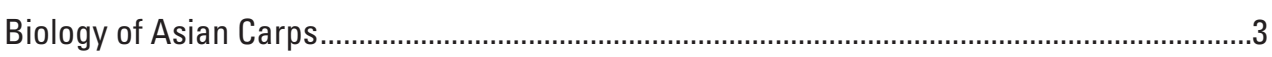

Surface-Water and Groundwater Hydrology ....................................................................

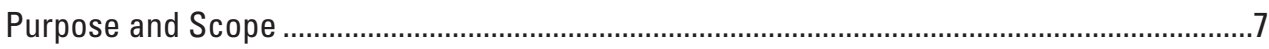

Methods of Investigation..................................................................................................

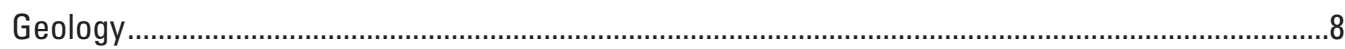

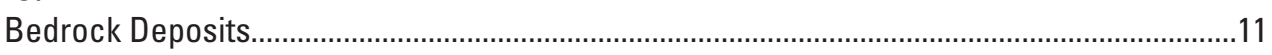

Unconsolidated Deposits ...................................................................................................

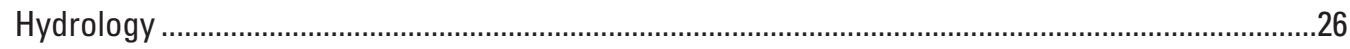

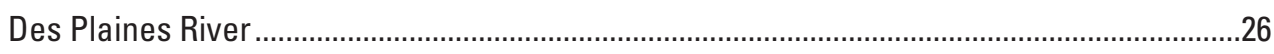

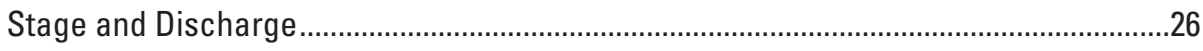

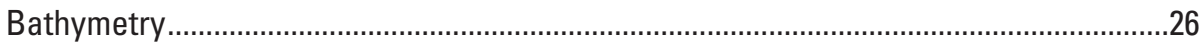

Composition of Bed Material .....................................................................................

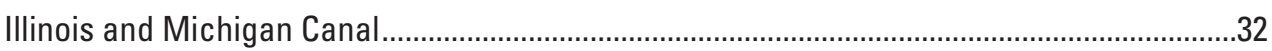

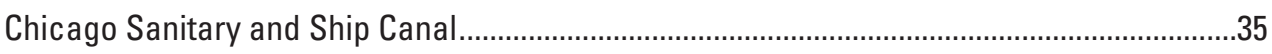

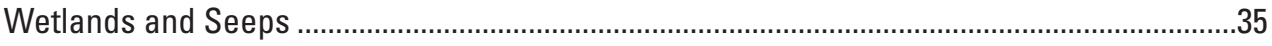

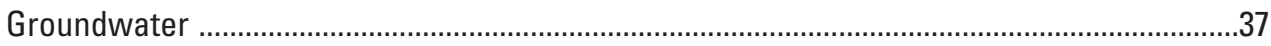

Implications of Water-Level Data Regarding the Potential for Interbasin Spread of Asian Carps by Way of the Groundwater Pathway..............................40

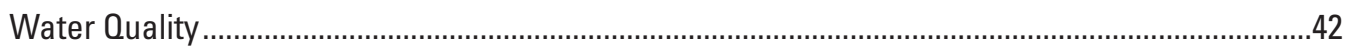

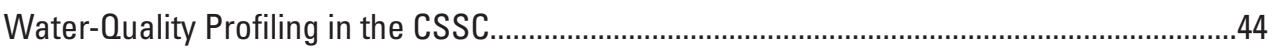

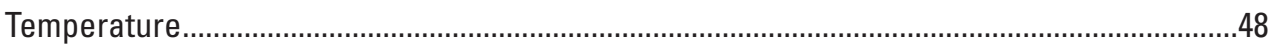

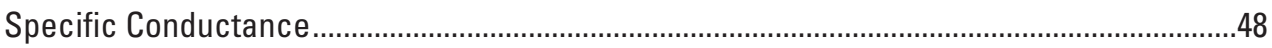

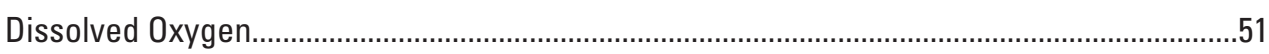

Implications of Water-Quality Data Regarding the Potential for Interbasin

Spread of Asian Carps by Way of the Groundwater Pathway..............................51

Potential for Interbasin Spread of Asian Carps by Way of the Groundwater Pathway....................53

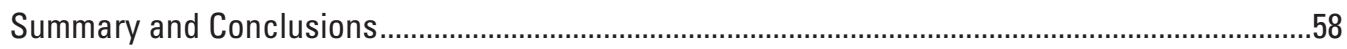

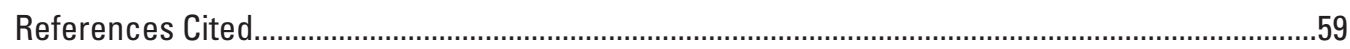

Appendix 1. Asian Carps in the United States .....................................................................62

Appendix 2. Map, Profiles, and Cross Sections of the Main Drainage Channel of the Chicago Sanitary and Ship Canal, from Chicago to Joliet, Illinois .................................79

Appendix 3. Methods of Data Collection and Analysis .................................................................8

Appendix 4. Detailed Geologic Assessment of the Bedrock Deposits...........................................86 


\section{Figures}

1. Map showing location of area of interest and selected features in the vicinity of the Des Plaines River, Chicago Sanitary and Ship Canal, and Illinois and Michigan Canal in northeastern Illinois

2. Map showing location of study area, focus area, and selected features in the vicinity of the Des Plaines River, Chicago Sanitary and Ship Canal, and Illinois and Michigan Canal between Stickney and Lockport, Illinois ...

3. Map showing location of direct-current resistivity surveys near Lemont, Illinois.

4. Aerial photograph showing location of selected wells, resistivity profiles, and line of geologic section near Lemont, Illinois.

5. Map showing location of data-collection points during the dye tracer test in the Des Plaines River near Lemont, Illinois, November 14-29, 2011 . .10

6. Chart showing stratigraphy, lithology, and secondary-permeability features in selected deposits of Silurian age near Lemont, Illinois .....

7. Photographs showing fractures and joints in the Silurian dolomite near Lemont, Illinois. $A$, Orthogonal joint pattern in Sugar Run Formation at Great Lakes Quarry between Chicago Sanitary and Ship Canal and Illinois and Michigan Canal, $B$, horizontal and vertical fractures in the Joliet and Sugar Run Formations, north wall of Chicago Sanitary and Ship Canal, 0.25 mile upstream of Lemont Road, $C$, vertical joints in Joliet Formation, north wall of Chicago Sanitary and Ship Canal, 0.1 mile downstream of Lemont Road, and $D$, vertical joints in Joliet Formation south wall of Chicago Sanitary and Ship Canal, 0.1 mile downstream of Lemont Road.

8. Map showing elevation of bedrock surface and thickness of unconsolidated deposits near the Des Plaines River and the Chicago Sanitary and Ship Canal near Lemont, Illinois

9. Graphs showing interpretation of direct-current resistivity survey data, site 4, survey profiles A-A' and B-B' near Lemont, Illinois, July 2010.

10. Map showing location of secondary-permeability features in the Silurian dolomite, seeps and points of inflow near the Chicago Sanitary and Ship Canal, and observed changes in water quality in the Chicago Sanitary and Ship Canal near Lemont, Illinois. $A$, Index map, $B$, from Romeo Road to southern part of the Vulcan Materials Romeoville Quarry, $C$, from Vulcan Materials Romeoville Quarry to boat slips east of $\mathrm{I}-355, D$, near Lemont Road, $E$, near boat slips east of Lemont Road, $F$, near confluence of Cal-Sag Channel and Chicago Sanitary and Ship Canal, G, near Red Gate Woods, and $H$, near Gilbert Avenue .....

11. Aerial maps showing possible paleokarst features in the Silurian dolomite near Lemont, Illinois. $A$, Joliet Formation, north wall of the Chicago Sanitary and Ship Canal, about 1.1 miles downstream of $\mathrm{I}-355$, $B$, Joliet Formation with chert horizon, north wall of the Chicago Sanitary and Ship Canal, 1.5 miles upstream of Romeo Road, $C$, Joliet Formation, north wall of the Chicago Sanitary and Ship Canal, about 1 mile downstream of I-355, $D$, Joliet Formation with apparent solution cavity terminated at water surface, north wall of the Chicago Sanitary and Ship Canal, about 2 miles upstream of Romeo Road, and $E$, solution cavity in Silurian dolomite infilled with Pennsylvanian clastics near Lemont, Illinois

12. Graph showing stage of the Des Plaines River at U.S. Geological Survey gage 05533600 and precipitation measured at U.S. Geological Survey gage 05533400 near Lemont, Illinois, April 1-November 30, 2011

13. Graph showing discharge of the Des Plaines River at U.S. Geological Survey gage 05533600 near Lemont, Illinois, April 1-November 30, 2011 
14. Photographs showing flood flow from the Des Plaines River to the Chicago Sanitary and Ship Canal near Willow Springs Avenue,

September 15, 2008.

15. Graph showing elevation of the lowest point of the bed of the Des Plaines

River along lines of transect, Riverside to Lockport, Illinois

16. Map showing composition of streambed in the Des Plaines River and degree of infilling of the Illinois and Michigan Canal near Lemont, Illinois

17. Photographs showing barriers to Asian carp spread along the Illinois and Michigan Canal near Lockport, Illinois. $A$, Texaco dam, 2.7 miles downstream of Romeo Road, March 30, 2010, B, Texaco dam, July 31, 2010, $C$, Deep Run Creek weir, 2.0 miles downstream of Romeo Road, March 30, 2010, D, Deep Run Creek weir, July 31, 2010, E, rock dam 2, 1.3 miles downstream of Romeo Road, March 30, 2010, and F, rock dam 2, July 31, 2010.

18. Photographs showing sediment and vegetation infilling of the Illinois and

Michigan Canal near Lemont, Illinois. $A$, Aerial view, about 1.8 miles upstream of Romeo Road, June 30, 2010, and B, Canal-level view, March 30, 2010.

19. Graph showing stage of the Chicago Sanitary and Ship Canal at U.S. Geological Survey gage 05536890, and precipitation measured at U.S. Geological Survey gage 05533400 near Lemont, Illinois, April 1-November 30, 2011

20. Photographs showing bathymetry and side-wall view of the Chicago Sanitary and Ship Canal. $A$, Examples of fractures and slab failure in the north wall of the canal approximately 1 mile downstream of I-355, $B$, examples of sediment mounds along the south wall of the canal approximately 0.7 mile upstream of Kingery Highway, $C$, two vehicles in the canal approximately 1 mile upstream of Lemont Road, and $D$, uncharted shipwreck along the south wall of the canal approximately 0.5 mile upstream of Lemont Road

21. Photographs showing discharge from wetlands along bedrock surface to the north wall of the Chicago Sanitary and Ship Canal near Lemont, Illinois, March 17, 2010. A, 1.5 miles upstream of Romeo Road (note karst-like feature in foreground), $B$, immediately downstream of I-355, $C$, near pipe arch about 0.1 mile upstream of Romeo Road, and $D, 1.5$ miles downstream of $\mathrm{I}-355$.

22. Photographs showing seeps along north wall of the Chicago Sanitary and Ship Canal near Lemont, Illinois. $A$, In the Joliet Formation, about midway between Romeo Road and I-355, May 4, 2010, and $B$, in the Sugar Run Formation, about 1.4 miles upstream of Lemont Road, March 17, 2010.

23. Graph showing geologic section $\mathrm{C}-\mathrm{C}^{\prime}$ and inferred groundwater level near Lemont, Illinois

24. Aerial photograph showing near-bed depth-averaged velocities measured near the north wall of the ACL slip in the Chicago Sanitary and Ship Canal on December 7, 2010, using an acoustic Doppler current profiler (ADCP)...

25. Graph showing groundwater levels at U.S. Geological Survey wells ACL-1, WP10-85, WS4-W1 and WS4-W2; stage in the Des Plaines River at U.S. Geological Survey gage 05533600; and stage in the Chicago Sanitary and Ship Canal at U.S. Geological Survey gage 05536890 near Lemont, Illinois, April 1-November 30, 2011

26. Aerial photograph showing water levels in wells and stage of surfacewater bodies in focus area near Lemont, Illinois, May 9-13, 2011. 
27. Graphs showing temperature and specific conductance data, and ratio of specific conductance and temperature of the Des Plaines River and the Chicago Sanitary and Ship Canal near Lemont, Illinois, February 19-March 6, 2010.

28. Graph showing temperature of the Des Plaines River at U.S. Geological Survey gage 05533600; the Chicago Sanitary and Ship Canal at U.S. Geological Survey gage 05536890; and of groundwater at U.S. Geological Survey wells ACL-1, WP10-85, WS4-W1, and WS4-W2; with precipitation at U.S. Geological Survey gage 05533400 , near Lemont, Illinois, April 1-November 30, 2011

29. Graph showing specific conductance of the Des Plaines River at U.S. Geological Survey gage 05533600; the Chicago Sanitary and Ship Canal at U.S. Geological Survey gage 05536890; and groundwater at U.S. Geological Survey wells ACL-1, WP10-85, WS4-W1, and WS4-W2; with precipitation at U.S. Geological Survey gage 05533400 , near Lemont, Illinois, April 1-November 30, 2011

30. Graph showing concentration of dissolved oxygen in the Des Plaines River at U.S. Geological Survey gage 05533600; in the Chicago Sanitary and Ship Canal at U.S. Geological Survey gage 05536890; and in groundwater in U.S. Geological Survey wells WP10-85, WS4-W1, and WS4-W2; with precipitation at U.S. Geological Survey gage 05533400 , near Lemont, Illinois, April 1-November 30, 2011.

31. Graphs showing concentration of dye tracer measured at selected locations and dates. $A$, The Des Plaines River at DP-1 (gage 05533500), DP-2 (gage 05533600), and DP-3 (Lockport lock and dam) near Lemont, Illinois, November 14-22, 2011, and B, groundwater at U.S. Geological Survey wells WP9-275, ACL-1, and WP10-85; in the Chicago Sanitary and Ship Canal at U.S. Geological Survey gage 05536890 (SC-1); and in the Chicago Sanitary and Ship Canal at the boat slip near well ACL-1 (SC-2) near Lemont, Illinois, November 14-29, 2011

32. Graph showing correlation of turbidity and reported concentration of rhodamine WT dye from the fluorometer mounted to a boat during repeated transects along the north bank of the Chicago Sanitary and Ship Canal from Romeo Road to 0.75 mile east of Kingery Highway near Lemont, Illinois, November 16, 2011

\section{Tables}

1. Summary of investigative activities near Lemont, Illinois

2. Summary of data collection during the tracer test on the Des Plaines River near Lemont, Illinois, November 14-28, 2011

3. Construction information for wells near Lemont, Illinois

4. Horizontal hydraulic conductivity values estimated from slug tests in wells and test intervals isolated by use of a packer assembly near Lemont, Illinois.

5. Groundwater levels near Lemont, Illinois, February 14-November 14, 2011.

6. Water levels in test intervals isolated by use of a packer assembly near Lemont, Illinois, February 15-23, 2011.

7. Concentration of selected constituents in groundwater at well WP10-85 near Lemont, Illinois, December 2, 2012

8. Summary of dye transport observations on the Des Plaines River near Lemont, Illinois, November 14-28, 2011 


\section{Conversion Factors and Datums}

\begin{tabular}{|c|c|c|}
\hline Multiply & By & To obtain \\
\hline \multicolumn{3}{|c|}{ Length } \\
\hline inch (in.) & 2.54 & centimeter $(\mathrm{cm})$ \\
\hline inch (in.) & 25.4 & millimeter (mm) \\
\hline foot $(\mathrm{ft})$ & 0.3048 & meter $(\mathrm{m})$ \\
\hline mile (mi) & 1.609 & kilometer $(\mathrm{km})$ \\
\hline \multicolumn{3}{|c|}{ Area } \\
\hline square mile $\left(\mathrm{mi}^{2}\right)$ & 2.590 & square kilometer $\left(\mathrm{km}^{2}\right)$ \\
\hline \multicolumn{3}{|c|}{ Volume } \\
\hline gallon (gal) & 3.785 & liter $(\mathrm{L})$ \\
\hline \multicolumn{3}{|c|}{ Flow rate } \\
\hline foot per second (ft/s) & 0.3048 & meter per second $(\mathrm{m} / \mathrm{s})$ \\
\hline cubic foot per second $\left(\mathrm{ft}^{3} / \mathrm{s}\right)$ & 0.02832 & cubic meter per second $\left(\mathrm{m}^{3} / \mathrm{s}\right)$ \\
\hline gallon per minute (gal/min) & 0.06309 & liter per second $(\mathrm{L} / \mathrm{s})$ \\
\hline gallon per day (gal/d) & 0.003785 & cubic meter per day $\left(\mathrm{m}^{3} / \mathrm{d}\right)$ \\
\hline million gallons per day (Mgal/d) & 0.04381 & cubic meter per second $\left(\mathrm{m}^{3} / \mathrm{s}\right)$ \\
\hline \multicolumn{3}{|c|}{ Mass } \\
\hline pound, avoirdupois (lb) & 0.4536 & kilogram (kg) \\
\hline \multicolumn{3}{|c|}{ Pressure } \\
\hline pound per square inch $\left(\mathrm{lb} / \mathrm{in}^{2}\right)$ & 6.895 & kilopascal $(\mathrm{kPa})$ \\
\hline \multicolumn{3}{|c|}{ Hydraulic conductivity } \\
\hline foot per day (ft/d) & 0.3048 & meter per day $(\mathrm{m} / \mathrm{d})$ \\
\hline \multicolumn{3}{|c|}{ Hydraulic gradient and slope } \\
\hline foot per mile (ft/mi) & 0.1894 & meter per kilometer $(\mathrm{m} / \mathrm{km})$ \\
\hline \multicolumn{3}{|c|}{ Transmissivity* } \\
\hline foot squared per day $\left(\mathrm{ft}^{2} / \mathrm{d}\right)$ & 0.09290 & meter squared per day $\left(\mathrm{m}^{2} / \mathrm{d}\right)$ \\
\hline
\end{tabular}

Temperature in degrees Celsius $\left({ }^{\circ} \mathrm{C}\right)$ may be converted to degrees Fahrenheit $\left({ }^{\circ} \mathrm{F}\right)$ as follows:

$$
{ }^{\circ} \mathrm{F}=\left(1.8 \times{ }^{\circ} \mathrm{C}\right)+32
$$

Temperature in degrees Fahrenheit $\left({ }^{\circ} \mathrm{F}\right)$ may be converted to degrees Celsius $\left({ }^{\circ} \mathrm{C}\right)$ as follows:

$$
{ }^{\circ} \mathrm{C}=\left({ }^{\circ} \mathrm{F}-32\right) / 1.8
$$

Vertical coordinate information is referenced to the North American Vertical Datum of 1988 (NAVD 88).

Horizontal coordinate information is referenced to the North American Datum of 1983 (NAD 83).

Elevation, as used in this report, refers to distance above the vertical datum.

*Transmissivity: The standard unit for transmissivity is cubic foot per day per square foot times foot of aquifer thickness [( $\left.\left.\mathrm{ft}^{3} / \mathrm{d}\right) / \mathrm{ft}^{2}\right] \mathrm{ft}$. In this report, the mathematically reduced form, foot squared per day $\left(\mathrm{ft}^{2} / \mathrm{d}\right)$, is used for convenience.

Specific conductance is given in microsiemens per centimeter at 25 degrees Celsius $(\mu \mathrm{S} / \mathrm{cm}$ at $\left.25^{\circ} \mathrm{C}\right)$.

Frequencies are given in hertz $(\mathrm{Hz})$ and kilohertz $(\mathrm{kHz}$ is equal to $1,000 \mathrm{~Hz})$. 



\title{
Geology, Hydrology, Water Quality, and Potential for Interbasin Invasive-Species Spread by Way of the Groundwater Pathway Near Lemont, Illinois
}

\author{
By Robert T. Kay, Patrick C. Mills, and P. Ryan Jackson
}

\begin{abstract}
Invasive species such as Asian carps have the potential to travel in the egg, larval, or fry stages from the Des Plaines River (DPR) to the Chicago Sanitary and Ship Canal (CSSC) by way of the network of secondary-permeability features in the dolomite aquifer between these water bodies. Such movement would circumvent the electric fish barrier on the canal and allow Asian carps to travel unimpeded into Lake Michigan. This potential pathway for the spread of Asian carps and other invasive species was evaluated by the U.S. Geological Survey.
\end{abstract}

The bed of the DPR appears to be in at least partial contact with the exposed bedrock in most of the area from about 1 mile west of Kingery Highway to Romeo Road (the study area). Areas of exposed bedrock are the most likely places for Asian carps to enter the groundwater system from the DPR. Water levels in the DPR typically are about 7-16 feet higher than those in the CSSC in most of the study area. This difference in water level provides the driving force for the potential spread of Asian carps from the DPR to the CSSC by way of groundwater.

Groundwater flow (and potentially invasive-species movement) is through an interconnected network of permeable vertical and horizontal fractures within the Silurian dolomite bedrock. At least some of the fractures are associated with paleo-karst features. Several investigative techniques identified horizontal permeable fractures at about 546-552 feet above the North American Vertical Datum of 1988 within about 55 feet of the CSSC in the focus area between Lemont Road and Interstate 355 . The elevation of the bottom of the CSSC in this area is about 551 feet, indicating that a direct conduit for flow of groundwater to the CSSC may be present. Wells further away from the CSSC in this area do not intercept fractures, so the fracture network may not be continuous between the DPR and the CSSC. These data are consistent with field observations of the secondary-permeability network along the CSSC walls, which indicate that the secondarypermeability features are completely filled with Pennsylvanian sediments within a few feet of the canal wall.
Water-level data indicate the potential for flow from the DPR into the Silurian aquifer in the focus area, then from the aquifer to the CSSC. Water-level data also indicate that the fractures within the aquifer in the focus area are hydraulically well connected to the CSSC but not to the DPR, indicating that flow from the DPR to the groundwater system may not be substantial or rapid.

Water-quality data in the CSSC and the DPR show similar values and trends and are affected by diel and longer term variations in climate and precipitation. However, the values and trends in water quality in the groundwater system tended to be substantially different from those in the DPR and the CSSC, indicating that the DPR and the CSSC do not appreciably recharge the groundwater system. Water-quality and flow data do indicate that groundwater discharges to the CSSC in part of the focus area. The absence of substantial hydraulic interaction between the groundwater and the DPR is supported by the absence of detectable concentrations of the dye tracer added to the DPR in groundwater in the focus area, which indicates that water from the DPR requires more than 2 weeks to move into the monitored parts of the groundwater system under approximately typical hydraulic conditions. The totality of the data indicates that there is minimal potential for the inter-basin spread of Asian carps by way of the groundwater pathway between Romeo Road and Stickney, Illinois.

\section{Introduction}

The Great Lakes and Mississippi River watersheds have several interconnections that could allow the inadvertent transfer of invasive species between the watersheds. The most direct interconnection is through the Chicago Area Waterway System along the Chicago Sanitary and Ship Canal (CSSC) in Cook, DuPage, and Will Counties, Illinois (Ill.) (fig. 1). The invasive species of most immediate concern for interbasin transfer are bighead carp (Hypophthalmichthys nobilis) and silver carp (H. molitrix). These invasive species have spread through much of the Mississippi River Basin, including the 


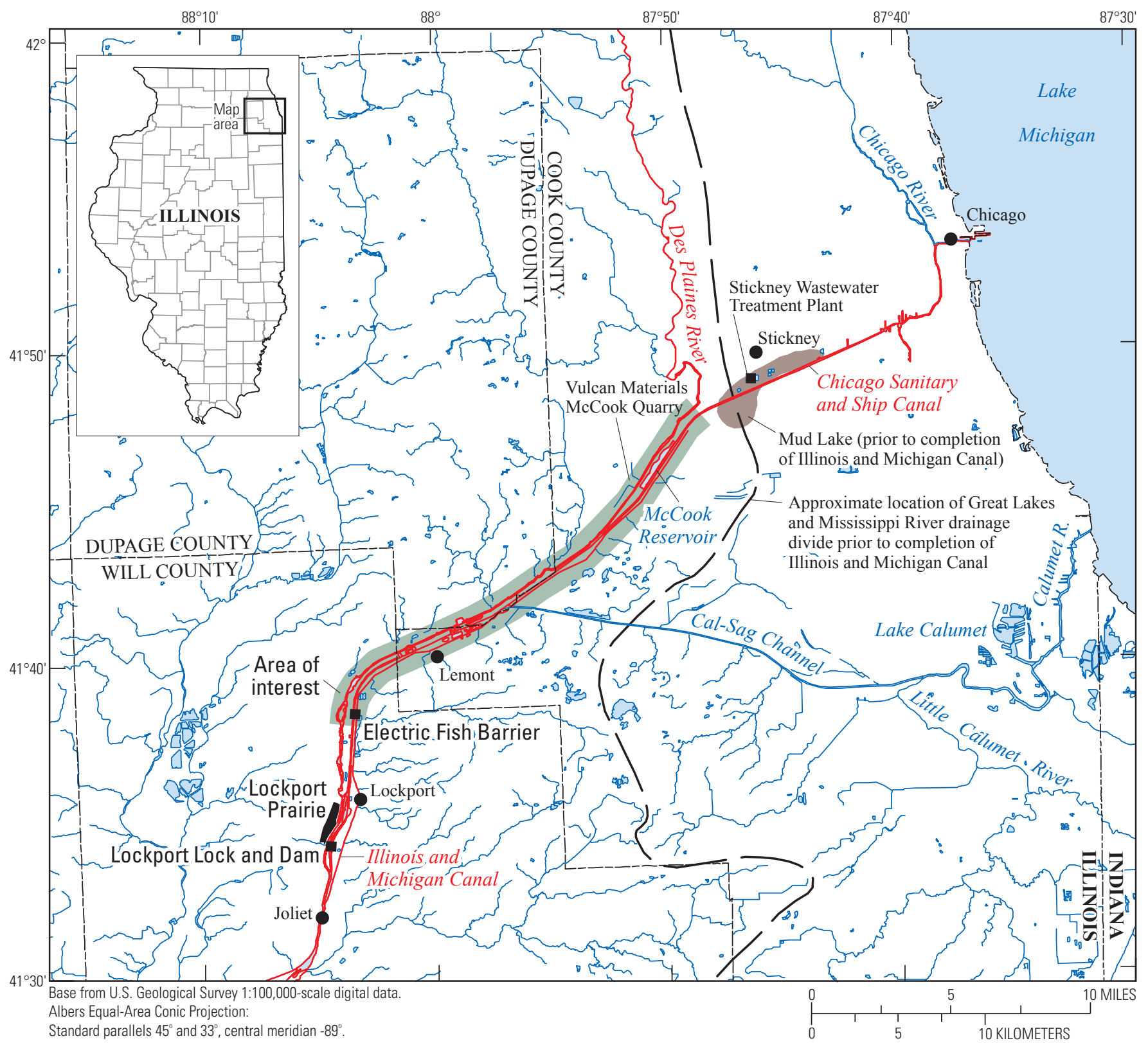

Figure 1. Location of area of interest and selected features in the vicinity of the Des Plaines River, Chicago Sanitary and Ship Canal, and Illinois and Michigan Canal in northeastern Illinois.

Illinois River, and have the potential to cause substantial ecological and economic damage to the Great Lakes (Appendix 1).

For the purposes of this report, bighead and silver carps are referred to collectively as "Asian carps." Black and grass carp, although of Asian origin, are either already present in the Great Lakes (grass carp) (Nico and others, 2012) or have not been identified in the upper reaches of the Illinois River system (black carp) (Nico, 2010) and are not included in this discussion. Although the investigation discussed herein focused on the potential for interbasin transfer of Asian carps, primarily in the egg and larval developmental stages, the findings may be applicable to other invasive species.

To prevent the spread of Asian carps between the Mississippi River and Lake Michigan watersheds, a pilot electric dispersal barrier has been in operation across the CSSC near Lemont, Ill., beginning in 2002 (fig. 1). Additional barriers (IIA and IIB) were added at the site to provide redundancy 
during periods of required maintenance or in case of failure of one or more barriers. The most recent barrier (I) is scheduled to begin operation in 2017. The barriers (hereafter referred to collectively as the "electric fish barrier") were constructed and are maintained by the U.S. Army Corps of Engineers (USACE). The electric fish barrier is not intended to prevent the spread of Asian carps into the Des Plaines River (DPR) or the historic Illinois and Michigan Canal (IMC). However, the spread of Asian carps into the IMC may be prevented by the Texaco dam on the IMC south of the electric fish barrier and by Rock Dam 2 south of the fish barrier (fig. 2).

The CSSC receives water from Lake Michigan by way of lakefront control structures on the Chicago and Calumet River systems northeast of the electric fish barrier (fig. 1). The CSSC flows into the DPR south of the electric fish barrier near Lockport and is then joined by the remnants of the IMC further downstream near Joliet (figs. 1, 2). This water eventually flows into the Illinois and then the Mississippi River.

The DPR, IMC, and CSSC are separated by an aquifer composed of fractured dolomite of Silurian age in much of the area upstream of the electric fish barrier. The degree of interconnection between the DPR, IMC, and CSSC through the secondary-permeability features (joints, fractures, faults, solution openings) in the dolomite aquifer has not been studied. However, there are concerns that carp eggs, larvae, and fry may be able to move through these secondary-permeability features from the DPR or IMC into the CSSC upstream of the electric fish barrier, thereby circumventing the electric fish barrier and allowing Asian carps to spread into Lake Michigan.

To assess the potential for Asian carps to circumvent the electric fish barrier by movement through secondary-permeability features in the dolomite aquifer, an investigation was done by the U.S. Geological Survey (USGS) in cooperation with the U.S. Environmental Protection Agency as part of the Great Lakes Restoration Initiative. The investigation identified the geologic, hydraulic, bathymetric, and sedimentary conditions that could influence the potential spread of Asian carp eggs, larvae, and fry from the DPR, through the dolomite aquifer, and into the CSSC. As the science bureau of the U.S. Department of Interior, the mission of the USGS includes conducting the scientific investigations to manage our Nation's resources. USGS investigations such as this one aid in the control of invasive species, preventing ecological and economic damage to the United States.

In this report the term "area of interest" refers to the area from the DPR, through the CSSC, to the IMC (where the IMC is present), extending from the electric fish barrier to where the DPR diverts to the north near Stickney (fig. 1). The term "study area" refers to that part of the area of interest from the fish barrier to about 1 mile (mi) northeast of Kingery Highway (fig. 2). The term "focus area" refers to that part of the area of interest from Lemont Road to Interstate 355 (I-355) (fig. 2).

\section{Biology of Asian Carps}

Asian carps feed on zooplankton and phytoplankton and were originally imported into the southern United States during the 1970s for control of algal blooms in aquaculture facilities, for human consumption, and for sewage treatment. The Asian carps escaped the aquaculture facilities and have since become established in the Mississippi River watershed, including the Illinois River. A bighead carp was captured on the CSSC less than 2 mi downstream of the electric fish barrier during a rotenone-application event in December 2009 (Patel and others, 2010), and a bighead carp was sighted on the DPR by an Illinois Department of Natural Resources biologist about $9.3 \mathrm{mi}$ south of the electric fish barrier in 2011. The environmental DNA (eDNA) of Asian carps, almost exclusively that of silver carps, has been detected in the CSSC, Chicago River, and Calumet River system upstream of the electric fish barrier (Appendix 1), and a bighead carp of uncertain origin was caught in Lake Calumet (fig. 1) in 2010 (Asian Carp Regional Coordinating Committee, 2012). However, no other Asian carps have been observed upstream of the electric fish barrier in spite of intensive monitoring, indicating that the eDNA detections may be due to vectors other than live carps.

Asian carps have a high fecundity, producing hundreds of thousands to more than a million eggs per spawn (Kolar and others, 2007). Asian carps typically spawn during periods of rising water levels in moderately warm (18-30 degrees Celsius) $\left({ }^{\circ} \mathrm{C}\right)$, turbid, rapidly flowing water (Kolar and others, 2007). The eggs absorb water for approximately 4 hours after they are spawned until they are almost neutrally buoyant in the surface water in which they are being transported (a process called water hardening). Water-hardened eggs can range in size from about 0.14 to 0.28 inches (in.) for bighead carp and 0.13 to 0.25 in. for silver carp (George and Chapman, 2013). The larvae of both species can be as large as about 0.33 in. Once fertilized, silver carp eggs have been documented to hatch in $21-33$ hours at a temperature of $22.5^{\circ} \mathrm{C}$ (Chapman and George, 2011), but development time varies with temperature and other factors. For example, George and Chapman (2013) recorded a 15-17 hour difference in hatching time for a temperature difference of less than $3{ }^{\circ} \mathrm{C}$.

Bighead carp can consume up to 20 percent of their body weight daily, can grow to nearly 5 feet (ft) in length, and can weigh up to 90 pounds (lbs). Silver carp can weigh up to $60 \mathrm{lbs}$ and can grow to more than $3 \mathrm{ft}$ in length. Mature Asian carps have no natural predator in the United States. As a consequence of their great numbers and ability to consume up to 20 percent of their body weight daily, Asian carps have the potential to cause substantial ecological damage to the Great Lakes by competing for food and habitat with native fish and affecting water quality as a result of their consumption of plankton (Kolar and others, 2007). A more complete summary of the biology of Asian carps and the threats and invasion risks posed by these fish is presented in Appendix 1 of this report. 


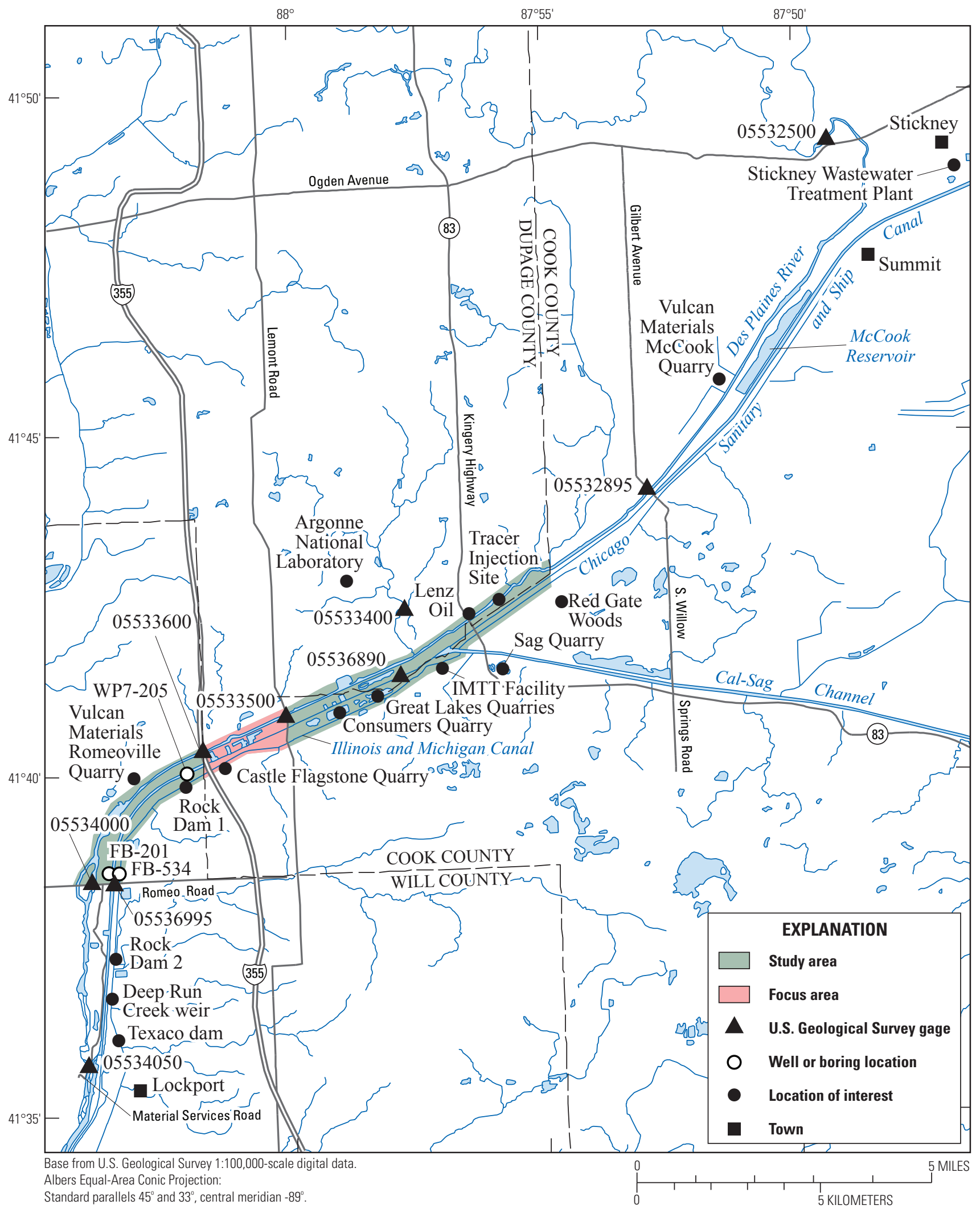

Figure 2. Location of study area, focus area, and selected features in the vicinity of the Des Plaines River, Chicago Sanitary and Ship Canal, and Illinois and Michigan Canal between Stickney and Lockport, Illinois. 


\section{Surface-Water and Groundwater Hydrology}

Under natural conditions, the Great Lakes and Mississippi River Basins in the Chicago area were separated by a drainage divide associated with a series of glacial moraines east of the DPR and extending south of the Little Calumet River into Indiana (Solzman, 2006) (fig. 1). In prehistorical times these moraines were breached by a glacial outwash channel that drained what is now Lake Michigan (Wilman, 1971). Erosion along the drainage channel created a topographic low point through the moraines from approximately Stickney to beyond the western end of the area of interest. Erosion associated with the drainage channel also resulted in the exposure of the surface of the dolomite bedrock in much of the area near Lemont. This topographic low point was (and remains) occupied by the DPR where its flow is to the southwest (fig. 1). East of the area where the flow in the DPR changes direction from south to southwest (near the village of Stickney), the low point was occupied by a wetland known as Mud Lake. Under natural conditions, the Mississippi River/ Lake Michigan drainage divide typically straddled Mud Lake (Solzman, 2006). However, during high-stage conditions, water from the DPR would flow into Mud Lake, overtop the drainage divide, and contribute flow to Lake Michigan.

As the Chicago area urbanized, the desire for a commercial transportation corridor between the Mississippi and Great Lakes Basins resulted in the construction of the IMC, which was completed in 1848 . The IMC connected Lake Michigan, by way of the south branch of the Chicago River, to the Illinois River at the town of Peru (Hill, 2000), approximately $85 \mathrm{mi}$ downstream of Lemont. The IMC is within the topographic low created by the glacial outwash drainage channel within the area of interest. While the IMC was operational, its width in the study area was about $60 \mathrm{ft}$, and its depth was about $8-15 \mathrm{ft}$. In much of the Lemont area, the IMC was excavated into the dolomite bedrock, which constitutes the walls of the IMC in most of the study area. The IMC ceased transportation operations in 1933, having been replaced by the adjacent and larger CSSC (fig. 2). As of 2013 the IMC was used only to receive stormwater discharge within the study area.

Construction of the CSSC was completed in 1900 (Solzman, 2006). The CSSC serves as a commercial shipping corridor between the Great Lakes and the Mississippi River and is the primary outlet for the Chicago Area Waterway System. Water in the CSSC is derived from flow from area streams, including the Cal-Sag Channel and the North Branch of the Chicago River (fig. 1), controlled flow from Lake Michigan, and secondary effluent from three water reclamation plants in the Chicago area. The CSSC follows a nearly identical path to the IMC from Chicago to its confluence with the DPR near Lockport (Appendix 2), being separated from the IMC by as little at $150 \mathrm{ft}$ within the study area.

The CSSC is about $160 \mathrm{ft}$ wide in the study area, with a typical water column of about $25 \mathrm{ft}$ (Appendix 2). The bottom of the CSSC has a constructed slope of about $1 \mathrm{ft}$ of decrease for every 20,000 to 40,000 lateral feet (Hill, 1896) and decreases in elevation from about $554 \mathrm{ft}$ North American
Vertical Datum of 1988 (NAVD 88) near Summit (fig. 2) to about $551 \mathrm{ft}$ at Romeo Road. Construction of the CSSC in much of the study area involved excavation into as much as $40 \mathrm{ft}$ of Silurian bedrock, which constitutes part or all of the canal walls in most of the study area (Appendix 2). Near the barge slips east of Lemont Road (fig. 3) and continuing at generally increasing depths eastward throughout the area of interest, the walls of the CSSC are lined with cut stone set block, which are designed to hold back the unconsolidated deposits that are present in generally increasing thickness along the walls of the CSSC upstream of about Kingery Highway (Appendix 2).

The natural channel of the DPR was straightened and diverted to the north in much of the study area to accommodate construction of the CSSC. The DPR and CSSC typically are about $800-900 \mathrm{ft}$ apart in the study area but are as little as 150-250 ft apart along the boat slips near Lemont Road (fig. 3).

Stage of the CSSC is primarily controlled by operations at the Lockport Lock and Dam, about 5 mi downstream of Romeo Road (fig. 1) (Jackson and others, 2012). The stage of the CSSC typically is maintained at about $576.7 \mathrm{ft}$ NAVD 88 within the study area to facilitate barge navigation. This stage is several feet lower than the lowest stage of the DPR in the study area. The stage of the CSSC often is lowered several feet for short periods during and in advance of precipitation events to accommodate stormwater discharge.

Continuous, large-scale horizontal fractures (Nicholas and Healy, 1988) and secondary-permeability features (in the form of vertical and horizontal fractures and solution openings) up to $2 \mathrm{ft}$ in height (Environmental Resources Management, 1990) have been observed in the Silurian dolomite aquifer that separates the DPR, CSSC, and IMC. Because the walls of the IMC and CSSC consist of dolomite bedrock in much of the study area, and the bed of the DPR also consists of dolomite bedrock in parts of the study area, secondarypermeability features in the aquifer may be in direct hydraulic communication with these surface-water bodies. These secondary-permeability features may be of sufficient size and interconnectedness to allow for carp eggs, larvae, or fry moving in the water or bed sediment of the DPR or IMC to rapidly move through the groundwater into the CSSC upstream of the electric fish barrier.

This potential for movement from the DPR through the aquifer into the CSSC is exacerbated by the propensity for Asian carps to spawn during flood periods. Flood periods typically are times of maximum head difference between the DPR and the CSSC because the stage of the CSSC is lowered prior to precipitation events and the stage of the DPR rises in response to runoff of precipitation. Conceptually, the large difference between the stage of the DPR and the CSSC would facilitate the movement of carp eggs, which have near neutral buoyancy, into fractures in the bottom and sides of the DPR. The large difference in stage also would result in the quickest travel time through the groundwater into the CSSC, which would increase the chances for the eggs' survival. 


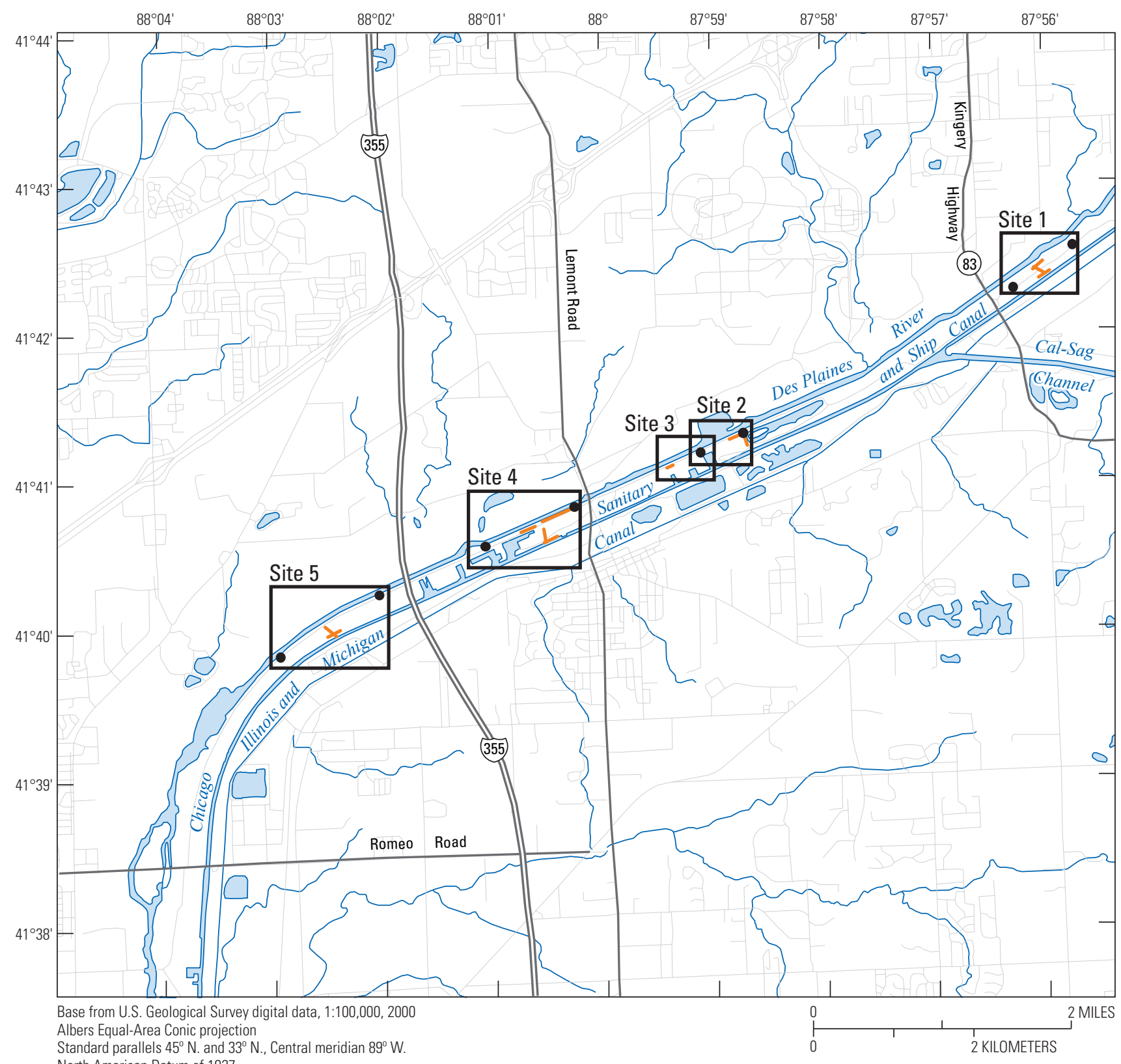

Standard parallels $45^{\circ} \mathrm{N}$. and $33^{\circ} \mathrm{N}$, Central meridian $89^{\circ} \mathrm{W}$.

EXPLANATION

- Direct-current resistivity profile location

- U.S. Army Corps of Engineers soil boring

Figure 3. Location of direct-current resistivity surveys near Lemont, Illinois. 


\section{Purpose and Scope}

This report summarizes the results of a series of investigative activities designed to assess the geologic and hydraulic factors that would affect the movement of the eggs and fry of Asian carp from the DPR or IMC to the CSSC by way of the Silurian dolomite bedrock within the area of interest. Although parts of this investigation were done throughout the entire 19-mi area of interest (fig. 1), the most intensive data collection occurred within the 9-mi-long study area and especially within the focus area (fig. 2). Data were collected from February 2010 through November 2011. This report describes the materials at the streambed, bathymetry, hydrology, and water quality on the DPR and CSSC and, to a lesser extent, the IMC. The report also describes the geology of the unconsolidated deposits and the hydrogeology and water quality of the Silurian dolomite aquifer between these surface-water bodies. Areas where there is the potential for water flow and egg movement from the DPR to the groundwater and to the CSSC, and the specific locations of possible pathways, are identified. The potential for successful spread of Asian carps and, by extension, other potential invasive species from the DPR to the CSSC by way of the groundwater pathway is discussed.

\section{Methods of Investigation}

Several investigative techniques were used to characterize the geology, hydrology, sediment, and water quality of the DPR, IMC, and CSSC, and the aquifer between these surfacewater bodies, within the area of interest. In combination, these techniques allowed for an assessment of the potential for interbasin spread of Asian carps by way of the groundwater pathway. The methods were sequenced so that the information gathered from a given investigative technique could be used to guide subsequent aspects of the investigation. Detailed discussion of the data collection and evaluation associated with the methods of investigation is presented in Appendix 3. The timing of the investigative activities is shown in table 1 .

Background information on the geology and the surfacewater and groundwater hydrology within the area of interest was compiled and evaluated. Of particular interest was background information identifying the areas where the stage of the DPR was higher than that of the CSSC, where the bed material in the DPR was bedrock, and where the walls of the CSSC and IMC consist of bedrock. This evaluation determined that the study area was the part of the area of interest where conditions were most likely to be favorable for interbasin spread of Asian carps by way of groundwater.

Once the study area was identified, a multi-beam echo sounder (MBES) survey of the CSSC was done. In addition, field geologic surveys of the bedrock stratigraphy and assessment of the secondary-permeability features along the IMC, DPR, and CSSC were made. These surveys identified the geometry of the walls and bottom of the CSSC as well as the location, type, and orientation of secondary-permeability features in the bedrock at and between the surface-water bodies. The background data and field geologic surveys also were used to guide the location of a field sediment survey to assess the composition of the materials at the bottom of the DPR. Water-quality and water-velocity profiling of the CSSC contemporaneous with the MBES survey identified potential anomalies in water velocity or water quality (temperature and specific conductance) along the walls of the CSSC that could indicate groundwater inflow from the DPR to the canal.

Surface direct-current (DC) resistivity surveys were made at five sites within the study area (fig. 3). The resulting data were used to identify areas where fractures capable of transmitting substantial amounts of water to the CSSC may be present. Selection of the specific locations of the DC-resistivity surveys was based on insights gained from evaluation of background information; geologic, sediment, and MBES surveys; and water-quality and flow profiling. These evaluations indicated that the focus area was the part of the study area where conditions were most likely to be favorable for interbasin spread of Asian carps by way of groundwater.

Wells ACL-1, WS4-W1, WS4-W2, WP9-275, and WP10-85 (fig. 4) were installed in the focus area, and well WP7-205 was installed west of I-355 (fig. 2). The location of these wells was based on the results of the DC-resistivity surveys. These wells provided direct access to the groundwater system to further characterize the secondary-permeability network and its ability to serve as a pathway for spread of Asian carps. All of these wells (in addition to USACE wells FB-201 and FB-534 shown on figure 2) were geophysically logged; the logs included caliper, natural gamma, fluid temperature, and a variety of normal conductivity logs. Selected wells in the focus area were logged with video camera and colloidal borescope. Selected wells in the focus area were subjected to slug testing and water-level measurements by use of a packer assembly to identify the type, location, and orientation of secondary-permeability features (or their absence) in the bedrock at these wells, in addition to the velocity and direction of groundwater flow through these features.

Continuous measurements of water levels and water quality were collected from USGS gages on the DPR and CSSC in and near the focus area and from selected wells in the focus area for various periods from April 1 through November 31,2011 . These data were used to assess flow directions and hydraulic interaction between the DPR and groundwater, and between groundwater and the CSSC, over a range of hydraulic conditions. This information also was collected to provide a rough estimate of the time required for water to move from the DPR, through the groundwater system in the focus area, to 
Table 1. Summary of investigative activities near Lemont, Illinois.

[CSSC, Chicago Sanitary and Ship Canal; DPR, Des Plaines River; IMC, Illinois and Michigan Canal]

\begin{tabular}{|c|c|c|c|}
\hline Activity & Location & Date & $\begin{array}{l}\text { Figure showing } \\
\text { location }\end{array}$ \\
\hline Bathymetric survey & CSSC in the area of interest & February and March, 2010 & Figure 1 \\
\hline $\begin{array}{l}\text { Measurement of secondary- } \\
\text { permeability features }\end{array}$ & $\begin{array}{l}\text { Outcrops on DPR, CSSC, and IMC and } \\
\text { quarries within the study area }\end{array}$ & March and May 2010 & Figures $2,9 \mathrm{~A}-\mathrm{H}$ \\
\hline $\begin{array}{l}\text { Direct-current resistivity } \\
\text { surveys }\end{array}$ & Between DPR and CSSC in study area & July 2010 & Figure 3 \\
\hline Water-velocity monitoring & CSSC in study area & December 2010 & Figures 2, 9A-9H, 24 \\
\hline Well drilling & Between DPR and CSSC in study area & December 2010 & Figures 2, 4 \\
\hline Borehole geophysical logging & Between DPR and CSSC in study area & $\begin{array}{l}\text { October and November } 2010 \text { and } \\
\text { January } 2011\end{array}$ & Figures 2,4 \\
\hline Water-quality monitoring & CSSC, DPR, and select wells in study area & $\begin{array}{l}\text { Various periods from April } 1 \\
\text { through November 31, } 2012\end{array}$ & Figures 2, 4 \\
\hline Dye tracer test & CSSC, DPR, and select wells in study area & November 14-19, 2011 & Figure 5 \\
\hline
\end{tabular}

the CSSC over a range of hydraulic conditions. Additionally, a water sample was collected from well WP10-85 to assess the major-ion chemistry of the aquifer in the focus area.

Finally, a dye tracer study was done. The movement (or absence of movement) of the rhodamine dye tracer from the DPR, through the groundwater system, and into the CSSC was observed to obtain a preliminary indication of whether or not Asian carp eggs also could move through this pathway, where within the study area that movement could occur, and whether the time of travel was likely to be small enough for the eggs to remain viable if and when they entered the CSSC. Monitoring for the presence and concentration of tracer was done primarily on the DPR, CSSC, and groundwater in the focus area, but also included monitoring of the DPR and CSSC throughout the study area (fig. 5, table 2). The monitoring was done with stationary field fluorometers deployed at fixed locations; portable field fluorometers deployed in a boat that made numerous traverses of the CSSC; and portable field fluorometers used to take measurements at selected locations in the DPR, CSSC, and wetlands near the DPR. Grab samples of water at various monitoring locations were collected and analyzed with a laboratory fluorometer to verify the measurements obtained by the field fluorometers.

\section{Geology}

The geologic units of concern to this investigation are the surficial bedrock and unconsolidated deposits. The unconsolidated deposits likely have interconnected pore spaces that are too small to allow water-hardened Asian carps eggs with a minimum diameter of 0.13 in. to pass through these deposits. Therefore, assessment of the type and location of the unconsolidated deposits was done primarily to identify where within the area of interest interbasin spread of Asian carps by way of the groundwater pathway was unlikely to occur, so as to reduce the area of investigation. Assessment of the bedrock geology primarily focused on characterizing the secondarypermeability network.

The geologic deposits in the area of interest, and especially the bedrock in the study area and focus area, were subjected to detailed characterization as part of this investigation. The most important features for assessing the potential for interbasin spread of Asian carps by way of the groundwater pathway are summarized here. More detailed evaluation of the geologic deposits based on the information obtained from this investigation is presented in Appendix 4. 


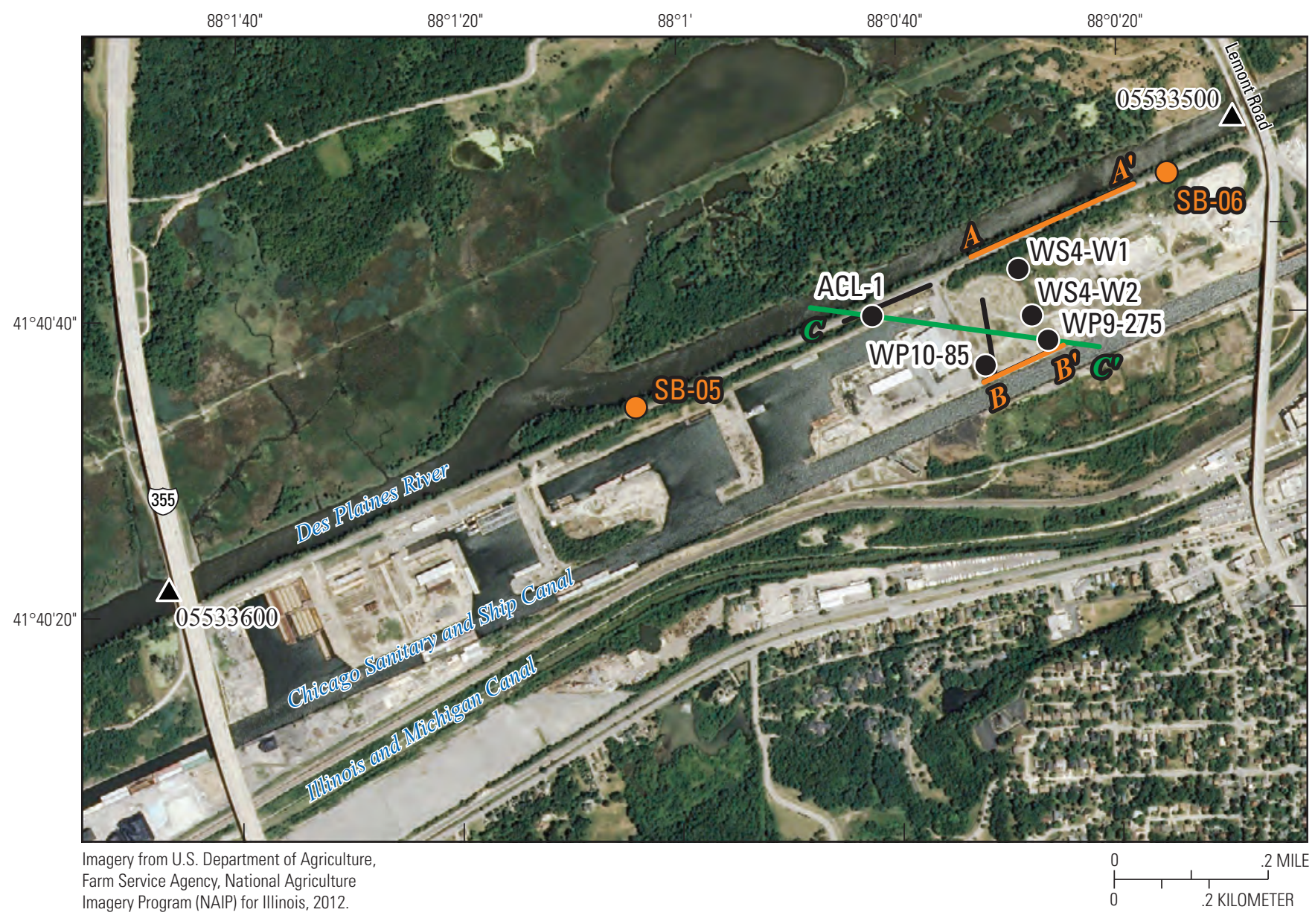

EXPLANATION

$\begin{array}{ll} & \text { Direct-current resistivity profile location } \\ & \text { Direct-current resistivity profiles } A-A^{\prime} \text { and } B-B^{\prime} \text { at } D C \text {-resistivity survey site } 4 \\ \text { ACL-1 } & \text { U.S. Geological Survey well location with identifier } \\ \mathrm{SB}=05 & \text { U.S. Army Corps of Engineers soil boring location with identifier }\end{array}$

Figure 4. Location of selected wells, resistivity profiles, and line of geologic section near Lemont, Illinois. 


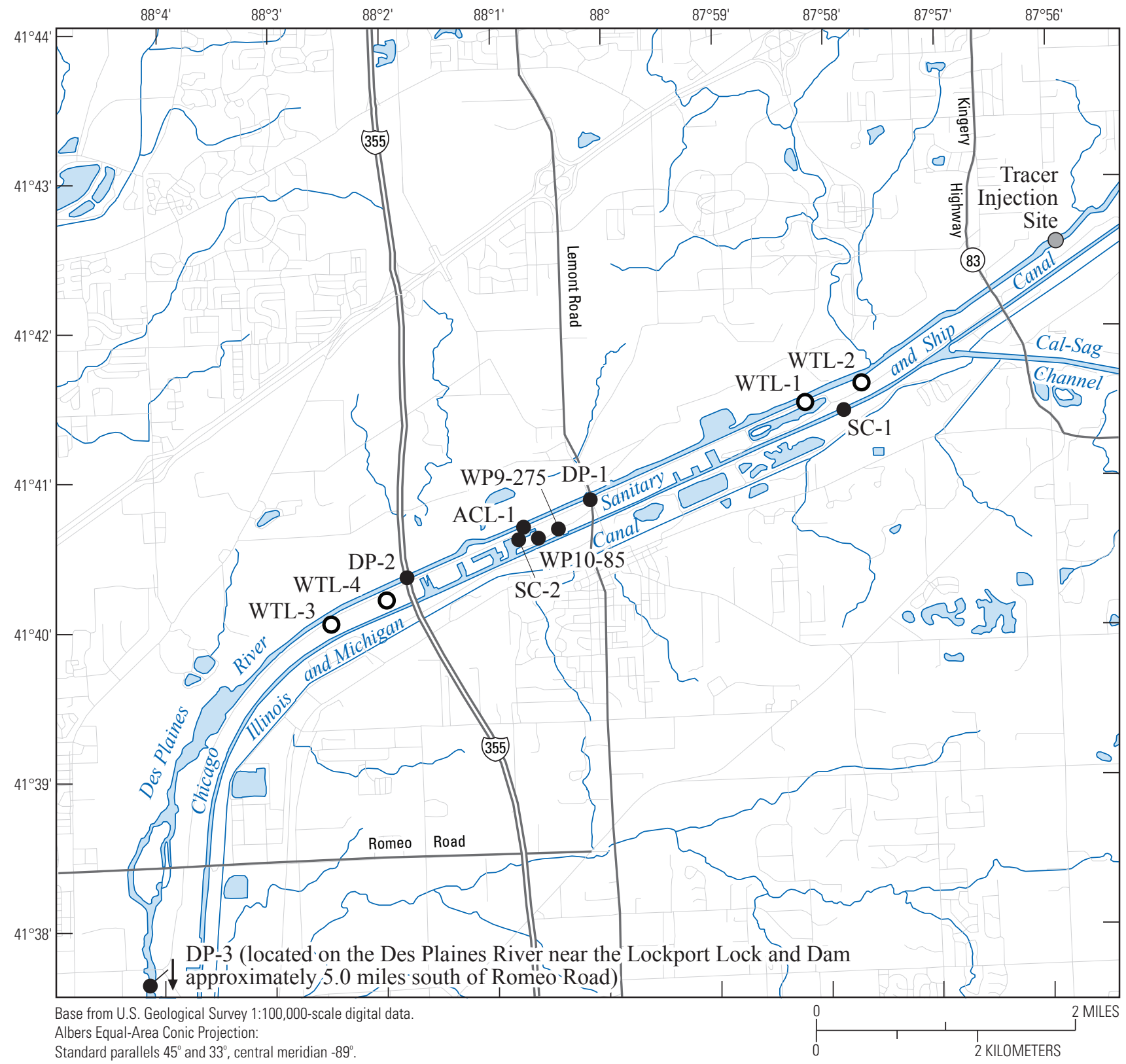

EXPLANATION

\section{ACL-1 Continuous tracer monitoring location and identifier \\ OWTL-1 Periodic tracer monitoring location and identifier}

Figure 5. Location of data-collection points during the dye tracer test in the Des Plaines River near Lemont, Illinois, November 14-29, 2011. 


\section{Bedrock Deposits}

The bedrock deposits of concern to this investigation consist of dolomite of Silurian age. These deposits are as much as $300 \mathrm{ft}$ thick within the area of interest. This investigation focused on the bedrock deposits within $70 \mathrm{ft}$ of land surface (elevation above about $520 \mathrm{ft}$ NAVD 88 in much of the focus area). This interval encompasses the elevation of the bottom of the CSSC and extends to about $30 \mathrm{ft}$ beneath the elevation of the bottom of the CSSC. This is the interval likely to contain secondary-permeability features capable of moving water - and Asian carps - from the DPR or IMC into the CSSC. Bedrock deposits have been incised and exposed in many places by construction of the CSSC and the IMC, past quarrying operations, and natural erosion (including erosion caused by flow of the DPR), facilitating characterization of these shallow deposits.

The stratigraphic units of concern to this investigation are the Joliet, Sugar Run, and Racine Formations. A detailed description of these formations is presented in figure 6 .
This investigation focused on characterization of the secondary-permeability network in the dolomite deposits within the area of interest. The secondary-permeability network within the area of interest includes vertical and inclined fractures (referred to as "vertical fractures" in this report) (fig. 7) as well as sub-horizontal fractures (referred to as "horizontal fractures" in this report), joints, solution openings, and perhaps a vertical fault. Singly or in combination, these secondary-permeability features are potential conduits for movement of Asian carps, so their location, orientation, and extent within the study area were characterized.

Previous investigators (Nicholas and Healy, 1988; KPRG and Associates Inc., 2004) identified several "sub-regional to regional" horizontal fractures at elevations of about 525, 550, 565, and $577 \mathrm{ft}$ NAVD 88 at the Red Gate Woods site and at about 561, 570, and $575 \mathrm{ft}$ near the International Matex Tank Terminals (IMTT) facility (fig. 2). These fractures are located along bedding planes within the Racine and (possibly) the upper part of the Sugar Run Formations, an indication that the presence and elevation of these fractures is affected by

Table 2. Summary of data collection during the tracer test on the Des Plaines River near Lemont, Illinois, November 14-28, 2011.

[CSSC, Chicago Sanitary and Ship Canal; DPR, Des Plaines River; mi, mile; mm, month; dd, day; yyyy, year; hhhh, hour]

\begin{tabular}{|c|c|c|c|c|c|}
\hline $\begin{array}{c}\text { Gage/ } \\
\text { well } \\
\text { name }\end{array}$ & $\begin{array}{l}\text { Location } \\
\text { (shown in figure 5) }\end{array}$ & Fluorometer type & $\begin{array}{l}\text { Beginning of data } \\
\text { collection } \\
\text { (mm/dd/yyyy hhhh) }\end{array}$ & $\begin{array}{c}\text { End of data } \\
\text { collection } \\
\text { (mm/dd/yyyy hhhh) }\end{array}$ & $\begin{array}{l}\text { Frequency of data } \\
\text { collection }\end{array}$ \\
\hline WP9-275 & Well WP9-275 & Turner Systems C-3 & $11 / 15 / 20110800$ & $11 / 29 / 20110950$ & 10 minutes \\
\hline WP10-85 & Well WP10-80 & Turner Systems C-3 & $11 / 14 / 20111545$ & $11 / 29 / 20111000$ & 10 minutes \\
\hline ACL-1 & Well ACL-1 & Turner Systems C-3 & $11 / 14 / 20111515$ & $11 / 29 / 20110930$ & 10 minutes \\
\hline $\mathrm{SC}-1$ & CSSC at USGS gage 05536890 & Turner Systems C-6 & 11/14/2011 1030 & $11 / 29 / 20110957$ & 3 minutes \\
\hline $\mathrm{SC}-2$ & CSSC boat slip near well ACL-1 & YSI-6920 & $11 / 14 / 2011$ & $11 / 17 / 2011$ & twice daily \\
\hline DP-1 & DPR at Lemont Road & Turner Systems C-3 & $11 / 14 / 20111300$ & $11 / 18 / 20110750$ & 15 minutes \\
\hline DP-2 & DPR at I-355 & Turner Systems C-3 & 11/14/2011 1300 & 11/18/2011 0803 & 15 minutes \\
\hline DP-3 & $\begin{array}{l}\text { DPR at Lockport lock and dam } \\
\text { (location shown in figure 1) }\end{array}$ & Turner Systems C-3 & $11 / 14 / 20111300$ & $11 / 29 / 20111328$ & 15 minutes \\
\hline WTL-1 & $\begin{array}{l}\text { Wetland along access road } 0.8 \\
\text { mi east of bike trail gate }\end{array}$ & YSI-6920 & $11 / 17 / 20110950$ & $11 / 17 / 20110950$ & Single event \\
\hline WTL-2 & $\begin{array}{l}\text { Wetland along access road } 1.3 \\
\text { mi east of bike trail gate }\end{array}$ & YSI-6920 & 11/17/2011 1000 & $11 / 17 / 20111000$ & Single event \\
\hline WTL-3 & Wetland north of well WP7-205 & YSI-6920 & $11 / 17 / 20111530$ & $11 / 17 / 20111530$ & Single event \\
\hline WTL-4 & $\begin{array}{l}\text { Wetland near storm grates at } \\
\text { gage } 05533600\end{array}$ & YSI-6920 & 11/17/2011 1700 & 11/17/2011 1700 & Single event \\
\hline
\end{tabular}




\begin{tabular}{|c|c|c|c|c|c|}
\hline System & Series & Formation & Member & Lithology & Secondary Permeability Features \\
\hline \multirow{9}{*}{ 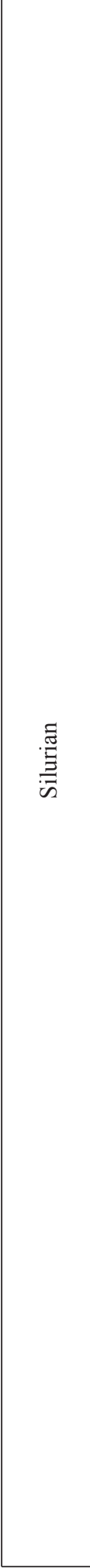 } & \multirow{9}{*}{ 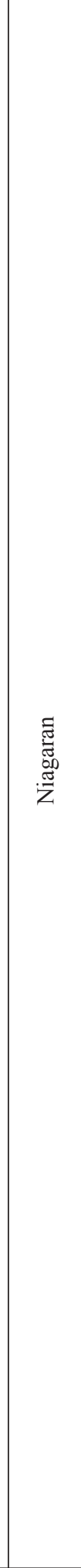 } & 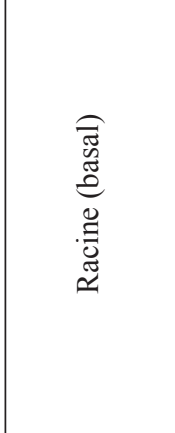 & & $\begin{array}{l}\text { Inter-reef strata, highly cherty, argillaceous } \\
\text { dolomite, overlain by massive, porous, crystalline, } \\
\text { pure dolomite. These lithologies recur in higher } \\
\text { strata. Other lithologies include bedded, porous, } \\
\text { crystalline, pure dolomite; non-cherty argillaceous } \\
\text { dolomite; thin dolomitic shales; and nodular } \\
\text { dolomite. May become more argillaceous in upper } \\
\text { strata, generally east of the study area. Typically } \\
\text { about } 80 \text { feet thick in northern part of area of } \\
\text { interest; thins to fully eroded in southern part. } \\
\text { Generally under-represented by fossils; dominated } \\
\text { by annelid worms. }\end{array}$ & $\begin{array}{l}\text { Prone to dissolution along bedding } \\
\text { planes, particularly above clay-rich } \\
\text { beds and less porous, well-bedded } \\
\text { Sugar Run Formation. North of Kingery } \\
\text { Highway, permeable "regional" } \\
\text { bedding-plane fractures at elevations of } \\
\text { about } 5 \text { to } 17 \text { feet below the bed of the } \\
\text { Des Plaines River (Environmental } \\
\text { Resources Management-North Central, } \\
\text { Inc.,1992a; Nicholas and Healy, 1988). } \\
\text { Karstic features identified at the Red } \\
\text { Gates Woods site (fig. 2). }\end{array}$ \\
\hline & & \multirow{3}{*}{ 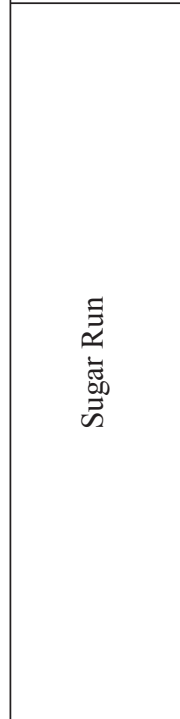 } & & $\begin{array}{l}\text { Well-bedded, even-textured, dense, nonporous, } \\
\text { argillaceous, gray dolomite, } 10 \text { to } 30 \text { feet thick. } \\
\text { Strata generally flat lying. Prominent, thin, } \\
\text { greenish-gray argillaceous partings cause the well- } \\
\text { bedded appearance. }\end{array}$ & \multirow[t]{3}{*}{$\begin{array}{l}\text { Generally not prone to dissolution } \\
\text { along bedding planes. Common near- } \\
\text { vertical joints generally sealed. }\end{array}$} \\
\hline & & & & $\begin{array}{l}\text { Fossils can be common and diverse. Thin, sinuous } \\
\text { trails, up to } 1 \text { foot long often found on bedding } \\
\text { surfaces, commonly filled with greenish-gray } \\
\text { argillaceous material. Trilobite } S \text {. celebra } \\
\text { characteristic of the unit; common to lower strata. } \\
\text { Other trilobites, crinoids, brachiopods debris } \\
\text { common, as is pelmatozoan debris. Orthoconic } \\
\text { nautiloids up to } 3 \text { feet in length distributed } \\
\text { throughout much of the formation. Sporadic } \\
\text { occurrence of large, dendritic root systems. }\end{array}$ & \\
\hline & & & & $\begin{array}{l}\text { Upper contact at the first appearance of rough- } \\
\text { textured, abundantly cherty, brown dolomite. }\end{array}$ & \\
\hline & & \multirow{5}{*}{$\stackrel{\stackrel{0}{\circ}}{\stackrel{\Xi}{\circ}}$} & \multirow{3}{*}{ 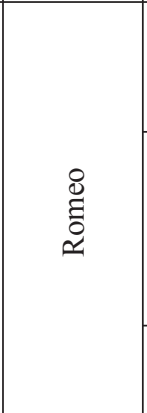 } & $\begin{array}{l}\text { Thick-bedded to massive, pure, porous to vuggy } \\
\text { dolomite, } 18 \text { to } 34 \text { feet thick. Nodular chert near } \\
\text { mid-unit; styolites common throughout. }\end{array}$ & \multirow{3}{*}{$\begin{array}{l}\text { Not prone to substantial dissolution } \\
\text { along near-vertical joints or bedding } \\
\text { planes. Local paleokarstic sinkholes } \\
\text { infilled with younger clastics, may be } \\
\text { eroded resulting as reentrants up to } 10 \\
\text { feet deep along Canal walls west of I- } \\
\text { 355. Common near-vertical joints } \\
\text { generally sealed. }\end{array}$} \\
\hline & & & & $\begin{array}{l}\text { In places a grainstone composed primarily of } \\
\text { pelmatozoan debris; locally very fossiliferous, } \\
\text { containing cystoids, various crinoids, trilobites, } \\
\text { gastropods, rugose corals, orthoconic nautiloids, } \\
\text { and diverse brachiopods. }\end{array}$ & \\
\hline & & & & $\begin{array}{l}\text { Upper contact gradational transition to the more } \\
\text { argillaceous dolomite of the Sugar Run. }\end{array}$ & \\
\hline & & & 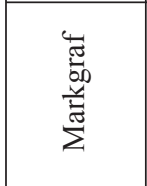 & $\begin{array}{l}\text { Medium-bedded dolomite, light gray, } \\
\text { approximately } 20 \text { feet thick. Basal unit silty. } \\
\text { Middle unit moderately argillaceous and silty with } \\
\text { bands of chert. Upper unit slightly argillaceous } \\
\text { with chert bands. }\end{array}$ & \multirow[t]{2}{*}{$\begin{array}{l}\text { Potentially prone to dissolution along } \\
\text { clay-rich bedding planes. }\end{array}$} \\
\hline & & & 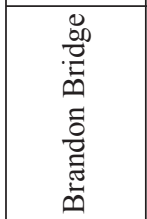 & $\begin{array}{l}\text { Lower part red crinoidal dolomite with interbedded } \\
\text { argillaceous red to grey dolomite becoming less } \\
\text { argillaceous, grey with red mottles in upper part. } \\
\text { Top of unit is uppermost strong shaley parting. } \\
\text { Approximately } 30 \text { feet thick. }\end{array}$ & \\
\hline
\end{tabular}

Figure 6. Stratigraphy, lithology, and secondary-permeability features in selected deposits of Silurian age near Lemont, Illinois (stratigraphy from Willman, 1971). 

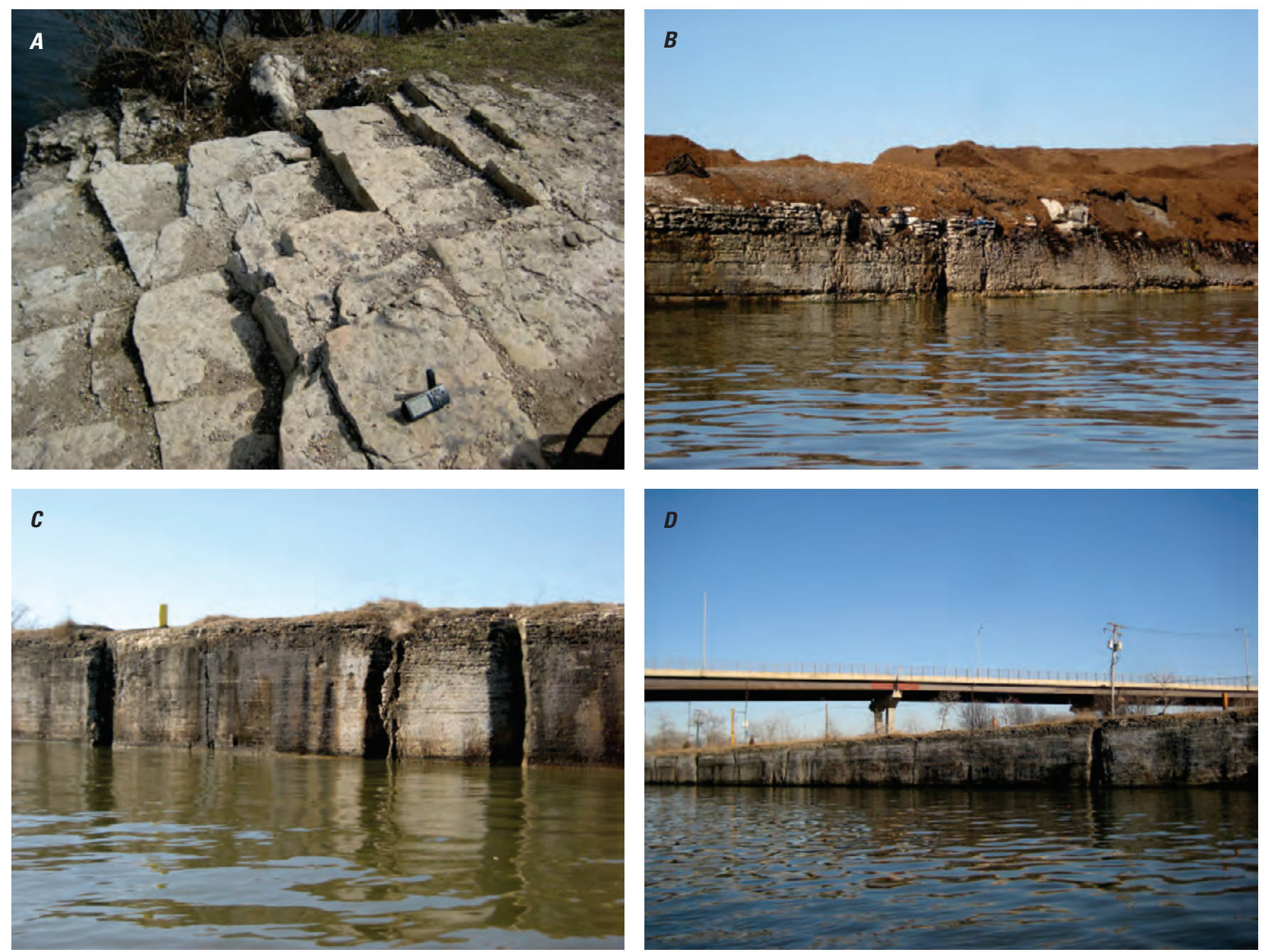

Figure 7. Fractures and joints in the Silurian dolomite near Lemont, Illinois. $A$, Orthogonal joint pattern in Sugar Run Formation at Great Lakes Quarry between Chicago Sanitary and Ship Canal and Illinois and Michigan Canal, $B$, horizontal and vertical fractures in the Joliet and Sugar Run Formations, north wall of Chicago Sanitary and Ship Canal, 0.25 mile upstream of Lemont Road, $C$, vertical joints in Joliet Formation, north wall of Chicago Sanitary and Ship Canal, 0.1 mile downstream of Lemont Road, and $D$, vertical joints in Joliet Formation south wall of Chicago Sanitary and Ship Canal, 0.1 mile downstream of Lemont Road.

the lithology and stratigraphy of these formations (which is variable within the study area) rather than being present at a constant elevation. These fractures can extend hundreds of feet in outcrops along the northern side of the DPR valley and may be continuous for more than a quarter mile. The aperture of the fracture at $550 \mathrm{ft}$ was estimated to be less than $0.14 \mathrm{in}$. (Shapiro and Nicholas, 1989).

Because the elevation of the bottom of the CSSC in the area of interest is about 551 to $554 \mathrm{ft}$ NAVD 88 , the horizontal fractures in the Racine Formation between about 550 and $577 \mathrm{ft}$ are of special concern to assessing the potential for interbasin spread of Asian carps by way of the groundwater pathway. These fractures are at the proper elevation to intersect the walls of the CSSC and could be extensive enough to also intercept the DPR, or to intercept vertical fractures or solution openings that intercept the DPR. However, the preponderance of the data collected for this investigation indicate that these fractures are absent from part or all of the area between the DPR and CSSC within the study area.

- The MBES surveys do not indicate a horizontal fracture (at the approximately 1.2-in. resolution limit employed during the surveys) near the bottom of the CSSC (near $550 \mathrm{ft}$ ) or at $565 \mathrm{ft}$ along the CSSC in the area near Red Gate Woods or elsewhere within the study area. Moored barges prevented MBES surveys from full access to the canal walls, but the obstructed areas were small (approximately 7.5 percent) relative to the extent of the MBES survey. Barges moored in the slips along the right bank of the canal constituted 5 
percent of the obstructed area, whereas barges moored in the main channel constituted another 2.5 percent. This limit of resolution is greater than the size of the carps' eggs and larvae (0.13-0.33 in.), so this finding is not a certain indicator of the absence of an important fracture. However, even small fractures in the dolomite are expected to have a larger expression at the CSSC because of weathering and the effects of construction, so an MBES survey with a 1.2-in. resolution is considered to be a useful indicator of the presence or absence of fractures along the wall of the CSSC as well as within the dolomite away from the CSSC.

- DC-resistivity surveys, field geologic surveys, and lithologic and geophysical logging of wells do not indicate the presence of substantial horizontal fractures within the dolomite between the DPR and CSSC in the area of interest, with the exception of the focus area.

- The elevation of the bedrock surface between the DPR and the CSSC indicates that the dolomite that would have contained these fractures has been removed by erosion within much the area of concern east of Kingery Highway, where data from well borings and the DC-resistivity survey at site 1 indicate the elevation of the top of the bedrock surface near the DPR is less than $541 \mathrm{ft}$ NAVD 88 (fig. 8).

DC-resistivity data indicate that substantial horizontal secondary-permeability features are absent from the bedrock between the CSSC and the DPR, except in the focus area at DC-resistivity survey site 4 (figs. 3, 8). At site 4, potential horizontal fractures are indicated near the DPR in the southwestern part of cross section A-A' (figs. 4, 9) below about $550 \mathrm{ft}$, potentially extending to the CSSC at about $563-571 \mathrm{ft}$ (figs. 3, 9). Site 4 also is near the area where field surveys identified a possible horizontal fracture (or possibly and erosional feature) along the wall of the CSSC at $578 \mathrm{ft}$ NAVD 88 (fig. 7B). However, lithologic and geophysical logging from the wells near site 4 indicates that the only fracture in this area is the thin (aperture less than $0.20 \mathrm{in}$.) horizontal fracture present between about 545 and $552 \mathrm{ft}$ NAVD 88 at wells ACL-1, WP9-275, and WP10-85 (fig. 4; table 3). This fracture at $545-552 \mathrm{ft}$ is within the Joliet Formation and does not have an obvious relation to a lithologic change in the dolomite. No fractures were identified in nearby wells WS4-W1 and WS4-W2. Because the fracture at 545-552 ft NAVD 88 has a similar elevation to the bottom of the CSSC (about $551 \mathrm{ft}$ NAVD 88), and because the fracture is present only in the wells within about $55 \mathrm{ft}$ of the CSSC, the fracture may have resulted from construction of the CSSC. Regardless of its origin, the 545- to 552-ft fracture does not appear to extend continuously from the CSSC to the DPR. For Asian carps to spread from the DPR to the CSSC through this fracture, one or more vertically oriented secondary-permeability features that intersect both the DPR and the fracture would have to be present.
The field geologic and MBES surveys performed for this investigation indicate that approximately 150 observed and potential vertical fractures are located along the walls of the CSSC (fig. 10A-H). These fractures are present from about the Red Gate Woods site to Romeo Road but are most numerous between about Romeo and Lemont Roads. The field geologic surveys indicate that the bedrock exposed at the land surface between the IMC, CSSC, and DPR and the bedrock exposed in outcrops along the DPR (bedrock was about $2 \mathrm{ft}$ above the water line at the time of the field survey) contained vertical fractures with no measureable aperture. Most of the vertical fractures identified at bedrock exposures along the walls of the CSSC and IMC also have no measureable aperture.

Five vertical secondary-permeability features (fractures and possible solution openings) with apertures of a few inches to about $10 \mathrm{ft}$ were observed along the walls of the CSSC and IMC near Romeo Road (figs. 10B, 11) where the CSSC and IMC are excavated into the Joliet Formation, Romeo Member. However, observation of these features during the field geologic surveys indicates they have no visible aperture within a few feet of the walls of the IMC and CSSC, indicating they might be related to canal construction.

The absence of an extensive network of large vertical secondary-permeability features in the study area is supported by the results of the DC-resistivity surveys and geophysical logging in the monitoring wells. Vertical secondary-permeability features were not indicated at DC-resistivity survey sites 1 , 2 , and 3 . The DC-resistivity surveys identified potential small vertical fractures at survey site 5 and two potential small to large vertical fractures or fracture clusters near the CSSC at survey site 4 (figs. 3, 4, 9) (Andrew Teeple, U.S. Geological Survey, written commun., 2010). The DC-resistivity data indicate these vertical fractures may have penetrated to depths of as much as $100 \mathrm{ft}$ and have a spacing between fractures in excess of $100 \mathrm{ft}$. However, fractures (vertical or horizontal) were not indicated during drilling or geophysical logging in wells WP7-205 (shown in figure 2), WS4-W1, and WS4-W2, which were drilled at locations where vertical fractures were indicated to be present by the DC-resistivity surveys. Vertical fractures also were not indicated (although horizontal fractures were) during geophysical logging in wells ACL-1, WP10-85, and WP9-275, which are near the CSSC at survey site 4 (locations shown in fig. 4). It is noted that intercepting a vertical fracture with a vertically oriented well can be difficult, even with DC-resistivity data indicating the location of a potential fracture, and it is possible these features are present but not intercepted.

\section{Unconsolidated Deposits}

Unconsolidated deposits overlie the dolomite bedrock and vary in type and thickness within the study area. Unconsolidated deposits are relatively thin or absent where the elevation of the bedrock surface is high west of DC-resistivity survey site 2 and thicker where the elevation of the bedrock 


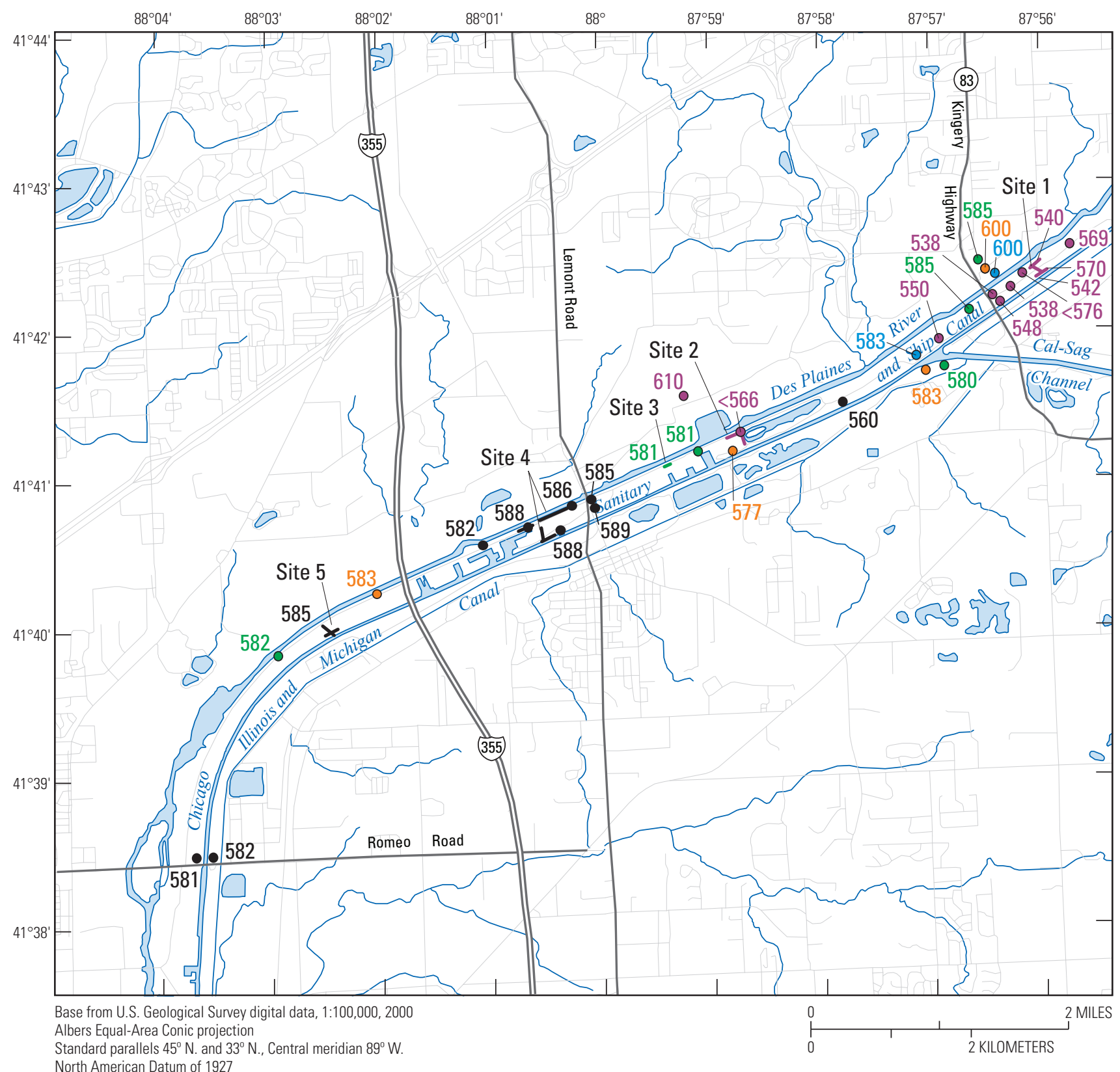

EXPLANATION

585 Direct-current resistivity profile location and bedrock-surface elevation

582 Soil boring and bedrock-surface elevation

Thickness of unconsolidated deposits at data point

- $x \quad$ Less than 1 foot

$\circ \times 1$ to 5 feet

$\circ \times 6$ to 10 feet

- $x \quad 11$ to 20 feet

$\circ \quad$ Greater than 20 feet

Figure 8. Elevation of bedrock surface and thickness of unconsolidated deposits near the Des Plaines River and the Chicago Sanitary and Ship Canal near Lemont, Illinois. 


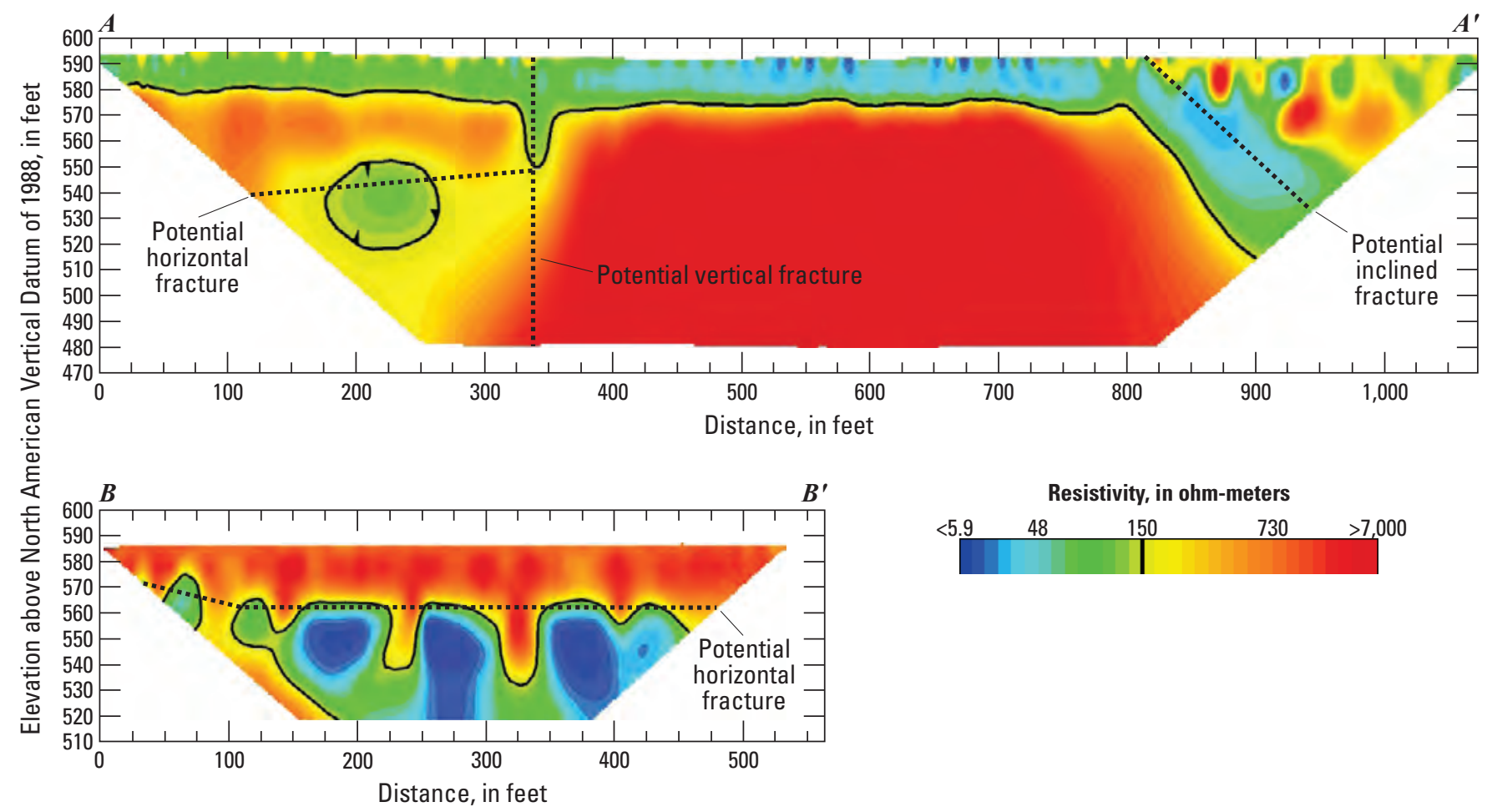

Figure 9. Interpretation of direct-current resistivity survey data, site 4, survey profiles A-A' and B-B' near Lemont, Illinois, July 2010 (profile location shown in figure 4).

Table 3. Construction information for wells near Lemont, Illinois.

[USGS, U.S. Geological Survey]

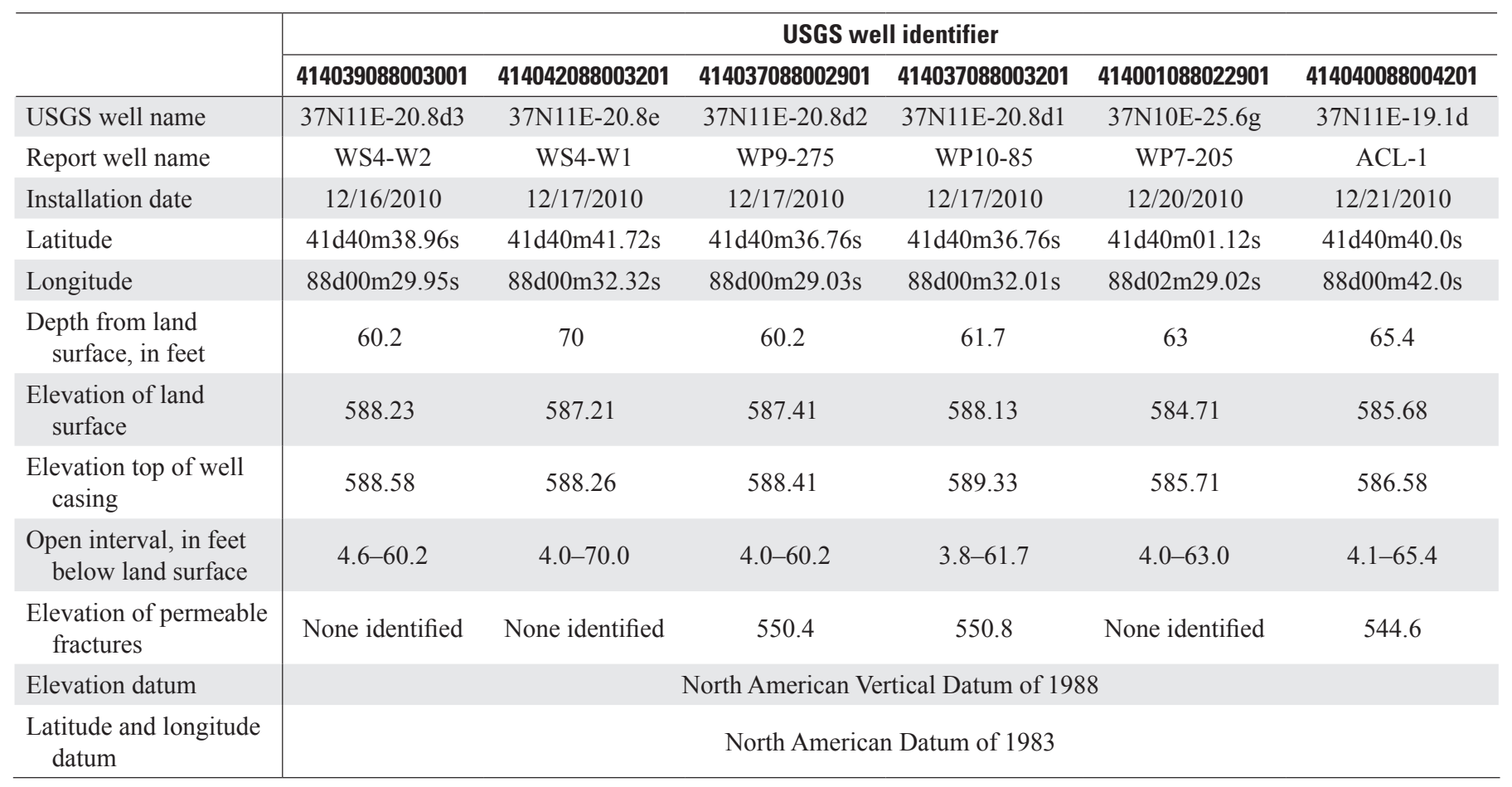


$\boldsymbol{A}$

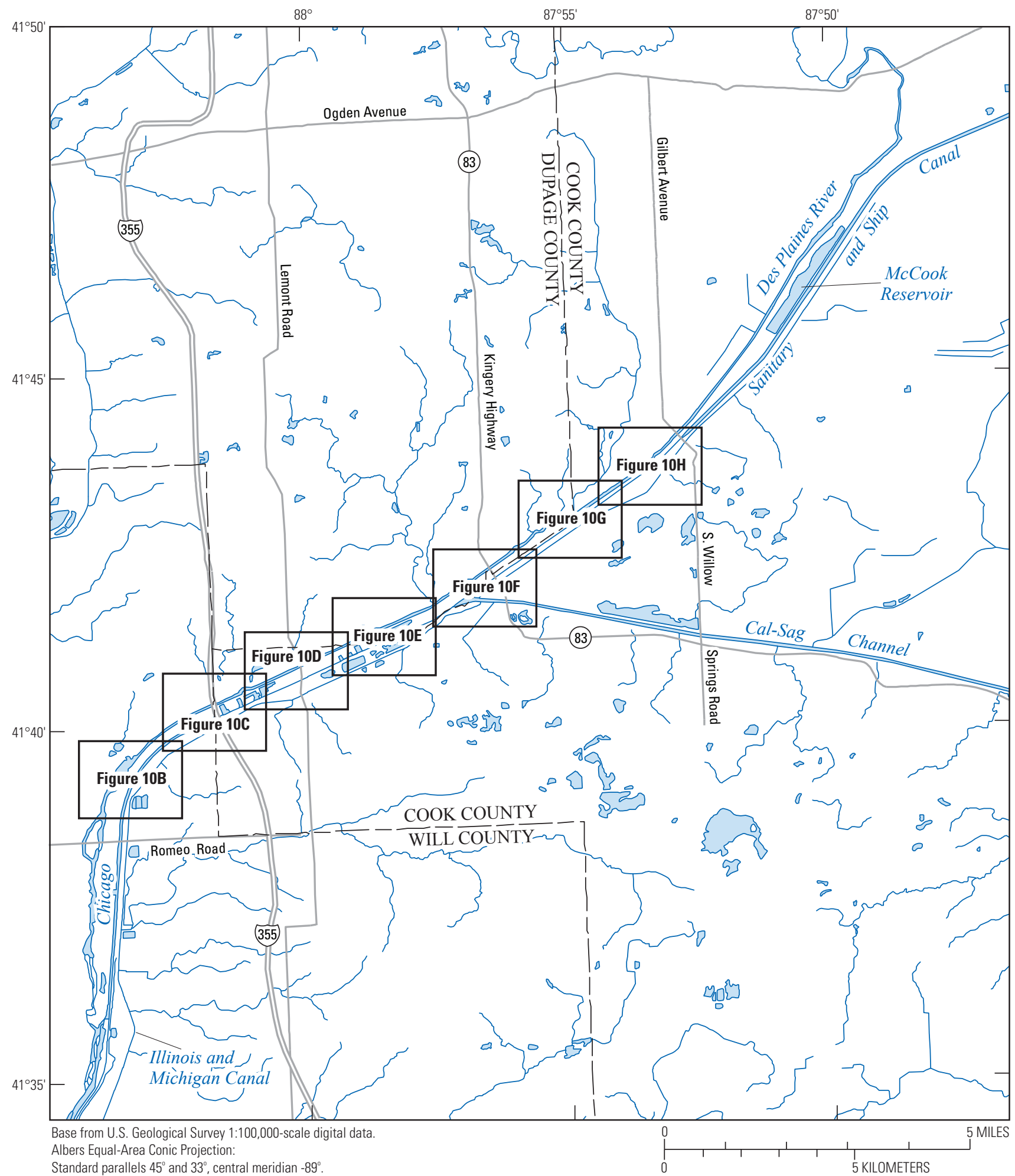

Figure 10. Location of secondary-permeability features in the Silurian dolomite, seeps and points of inflow near the Chicago Sanitary and Ship Canal, and observed changes in water quality in the Chicago Sanitary and Ship Canal near Lemont, Illinois. $A$, Index map, $B$, from Romeo Road to southern part of the Vulcan Materials Romeoville Quarry, $C$, from Vulcan Materials Romeoville Quarry to boat slips east of I-355, $D$, near Lemont Road, $E$, near boat slips east of Lemont Road, $F$, near confluence of Cal-Sag Channel and Chicago Sanitary and Ship Canal, G, near Red Gate Woods, and $H$, near Gilbert Avenue. 


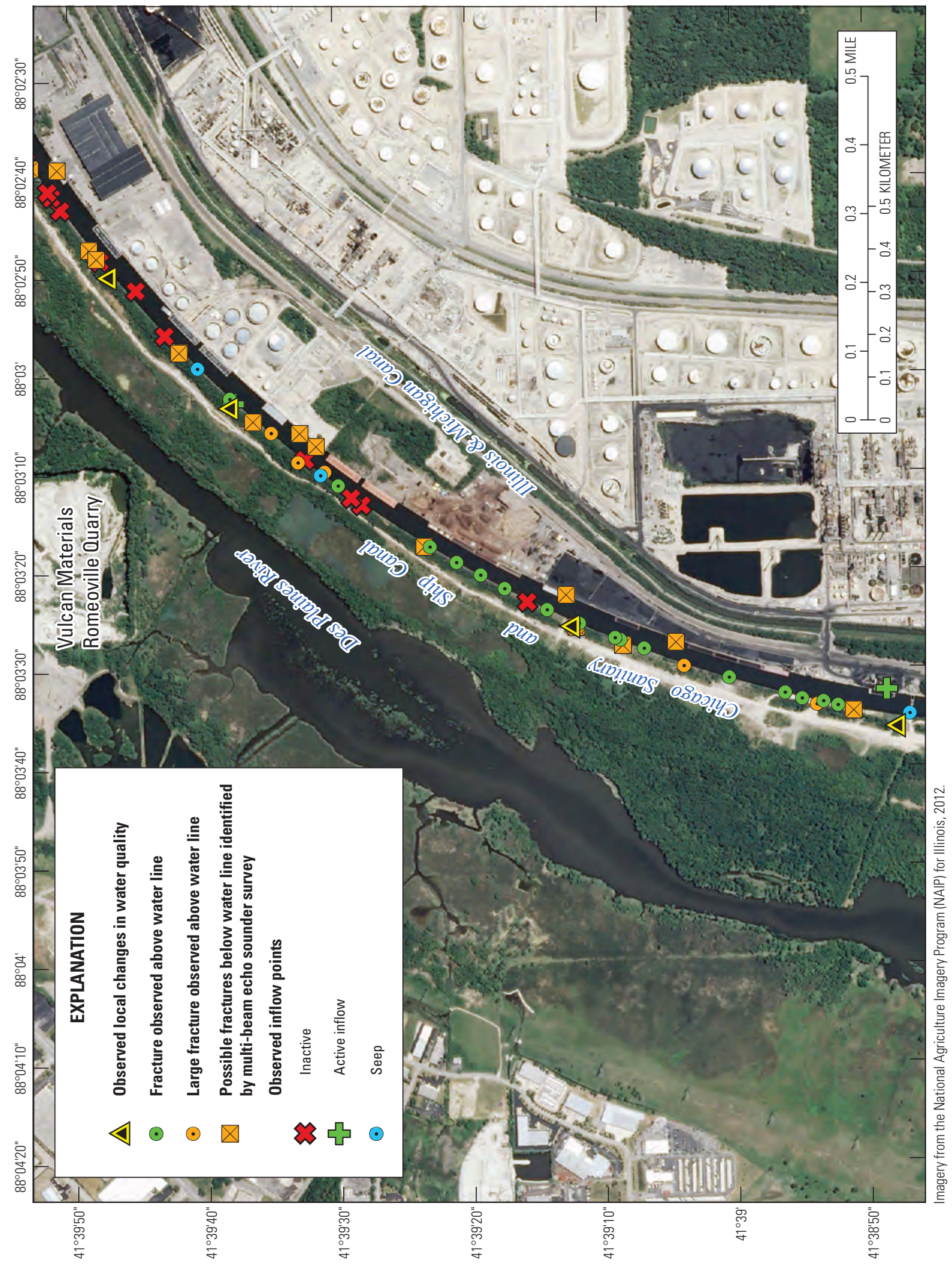

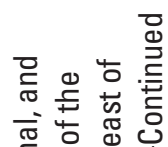

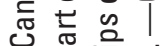

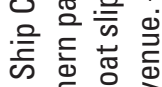

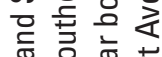

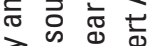

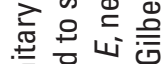

需

눙 욷

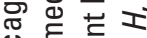

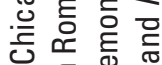

든

离航

这分

ว

잉ㅁㅇㅇ

드 뚱

帝范若

흥

完竎鱼向

政苋

ఖ

ब 3 क

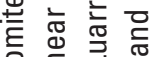

응 등 음

뜬

产鱼焉

욤

吉完此

$\subseteq \geq$

क त

空 $\Sigma$

क ळ

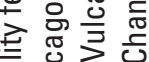

흘

ब

结导心赔

․․

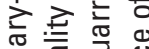

즌 可

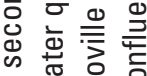

¿

ธᄃ $\subseteq$ 흐

을

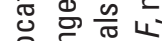

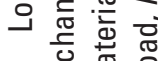

웡 $\sum^{\pi}$

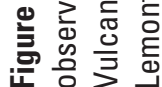




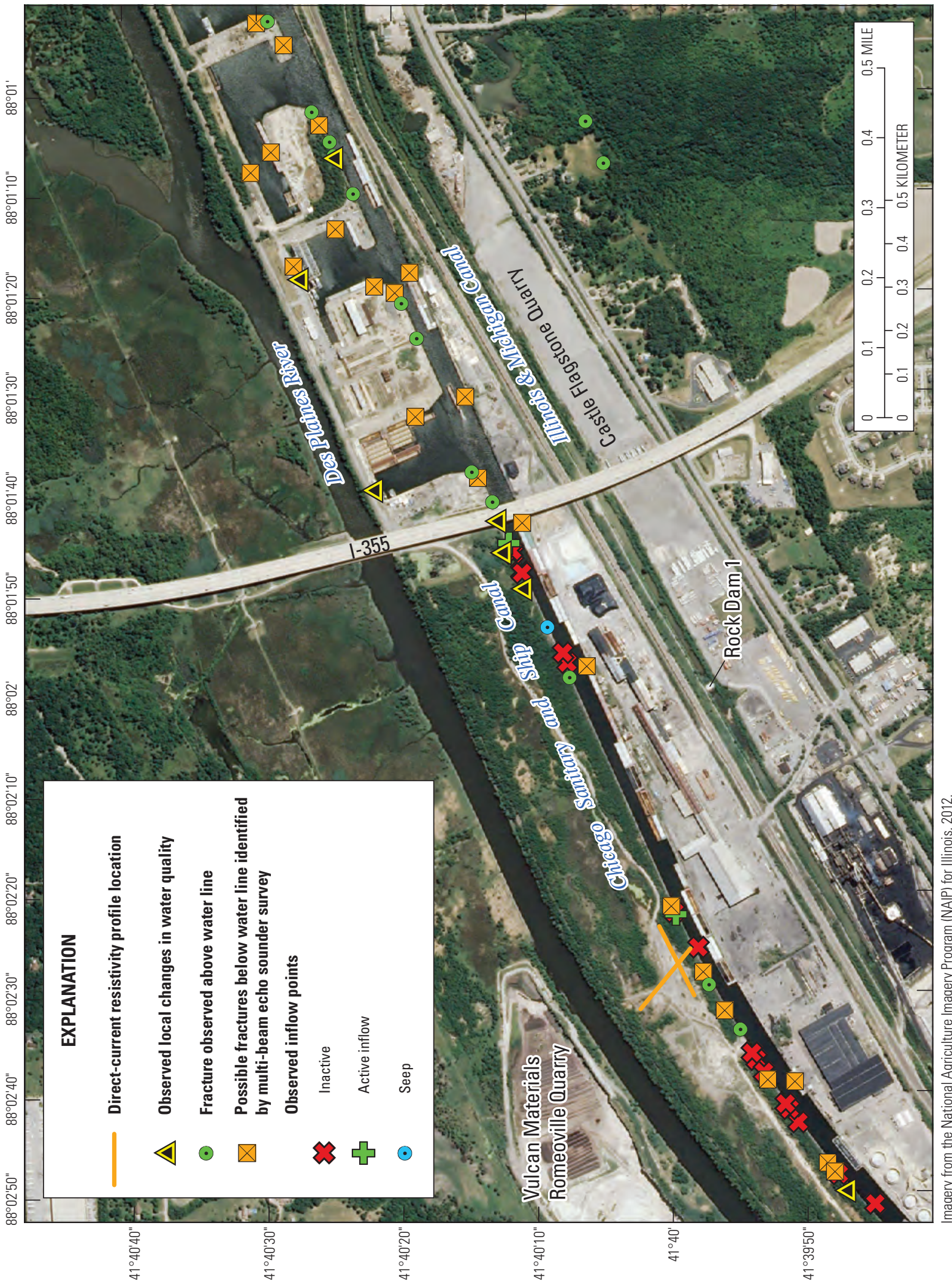

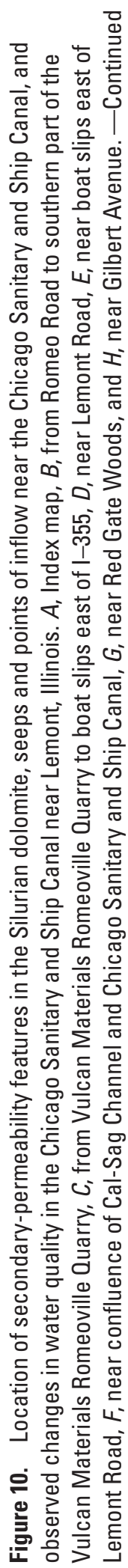




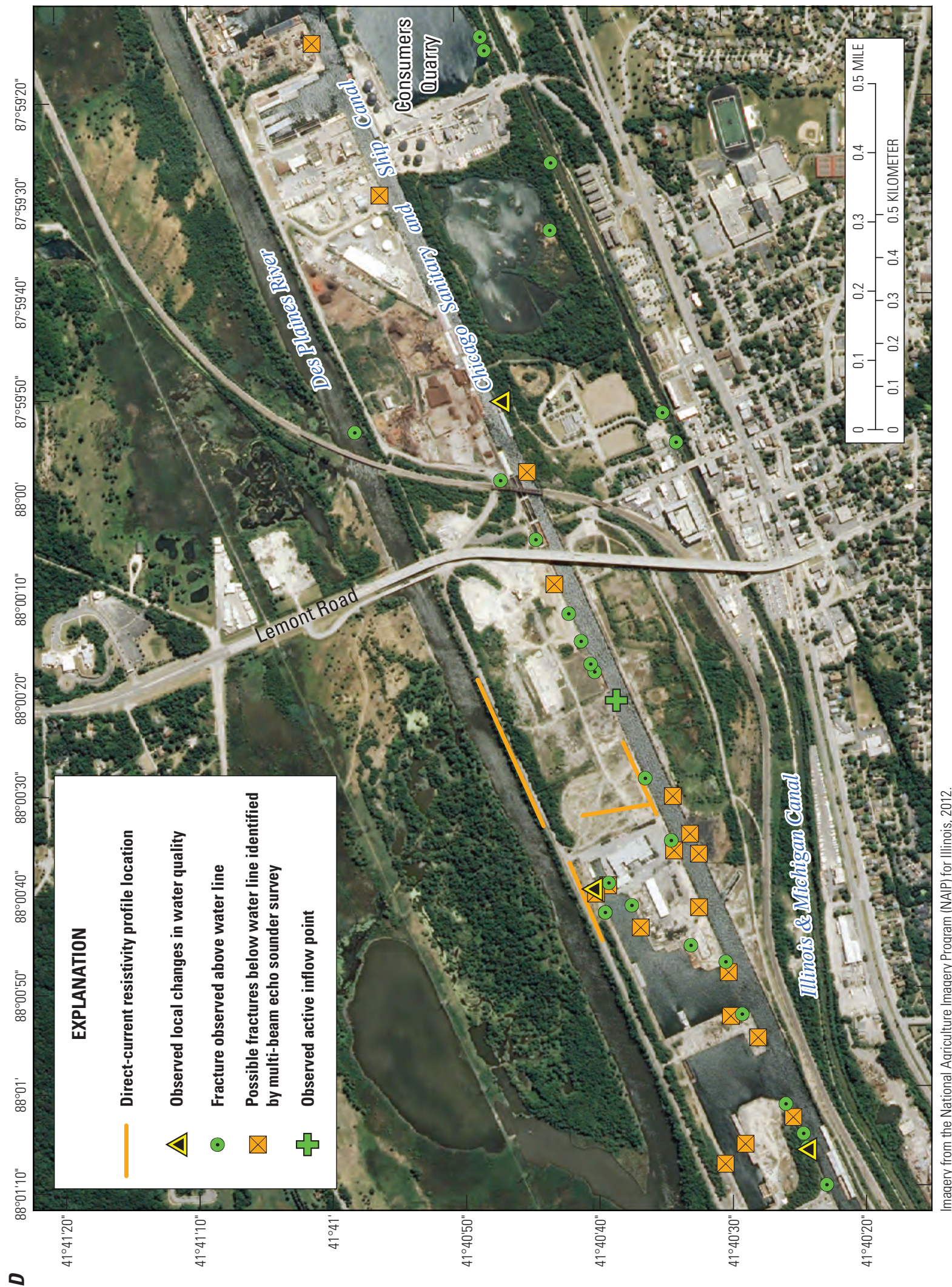

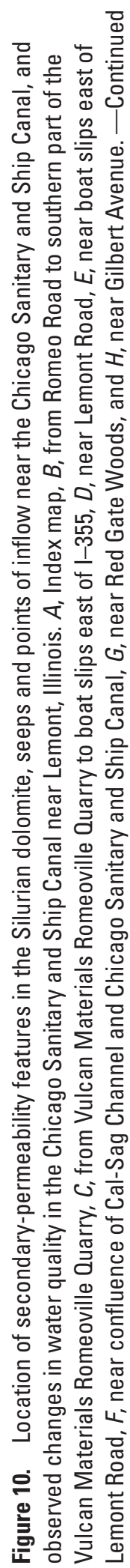




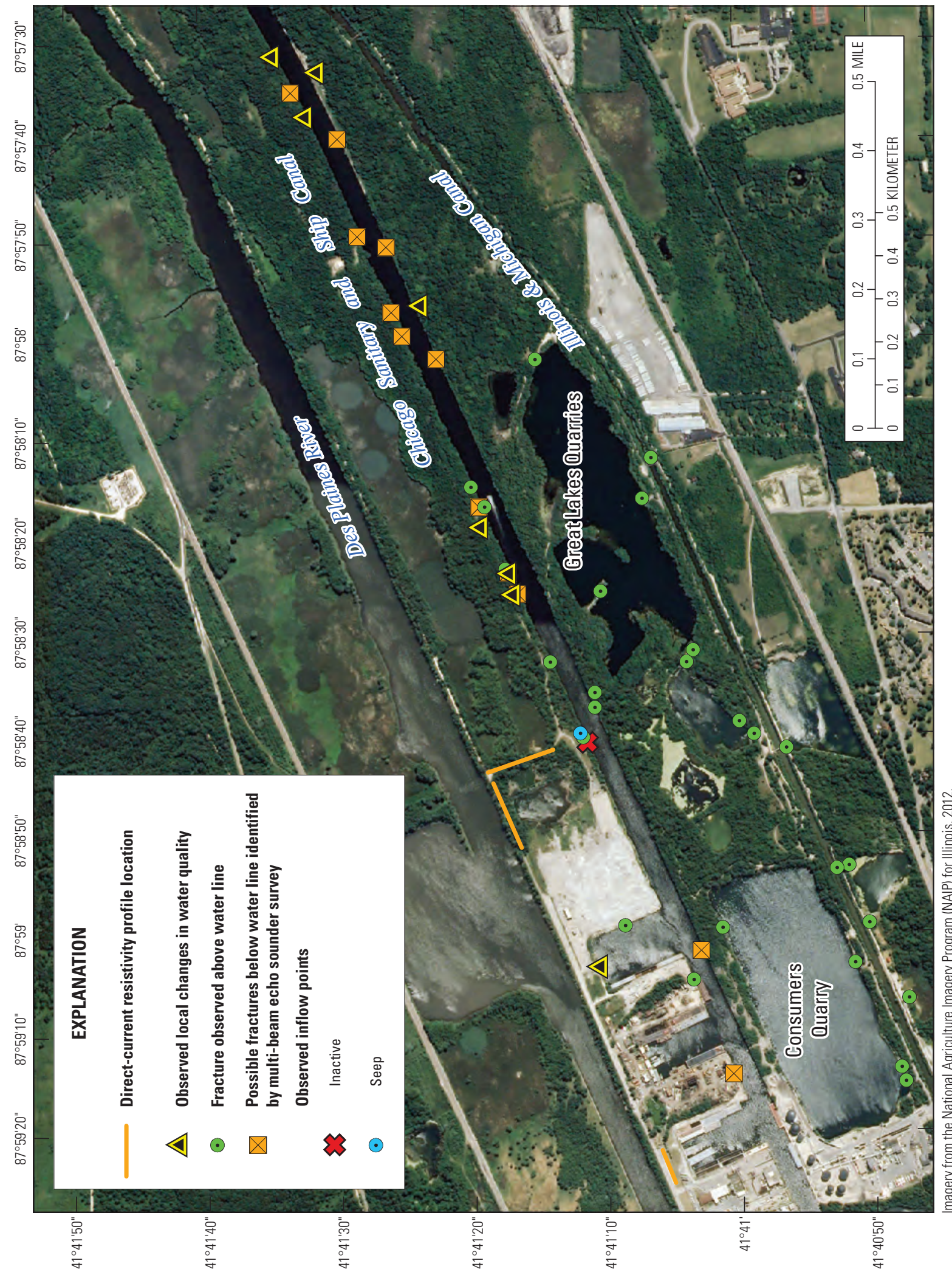

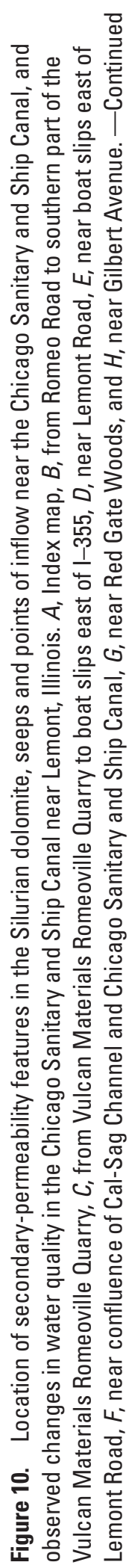




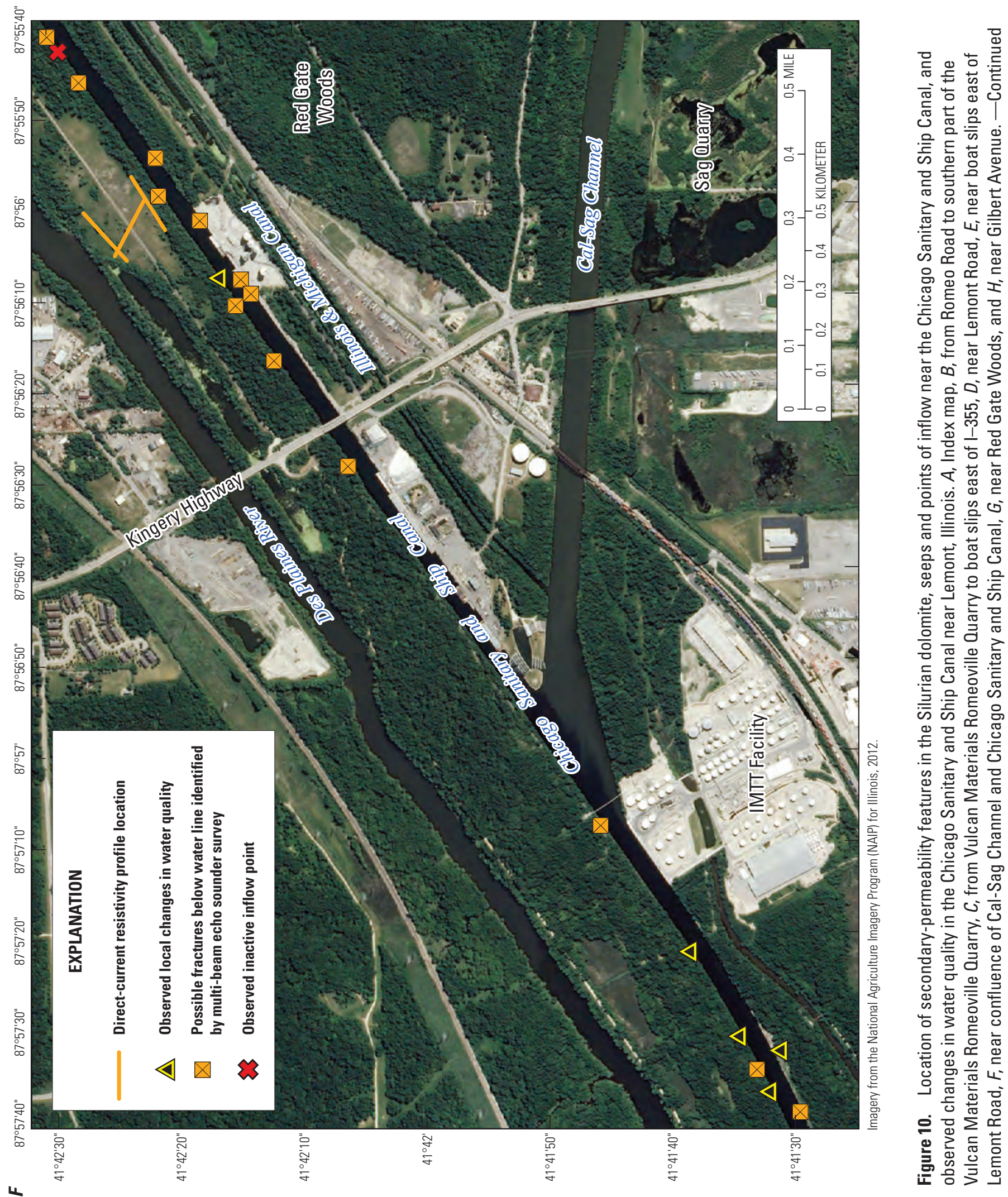




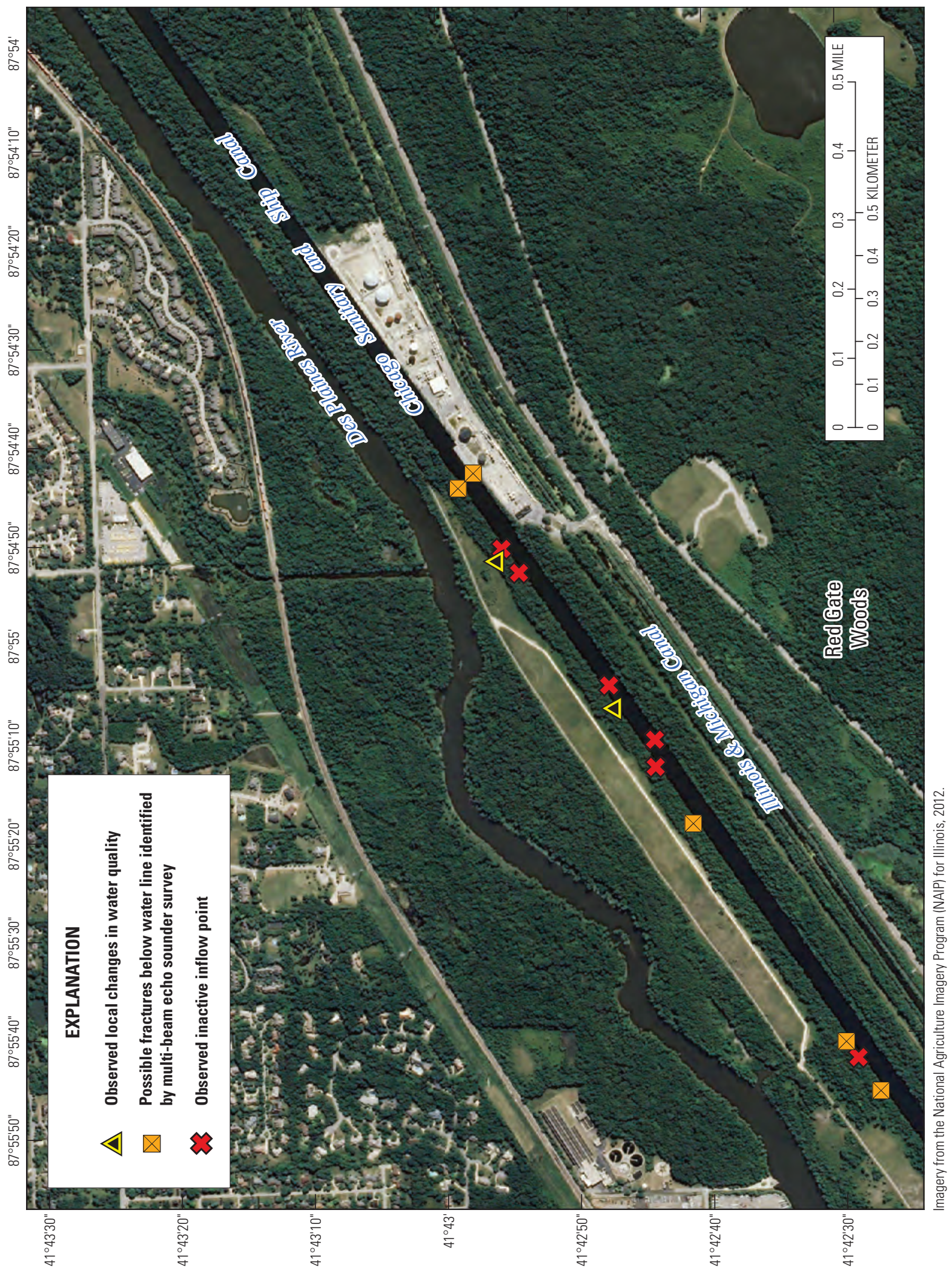

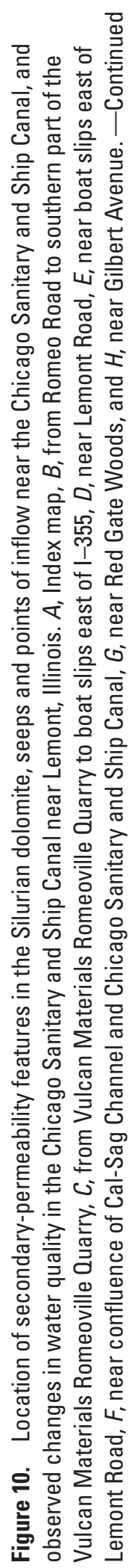

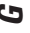




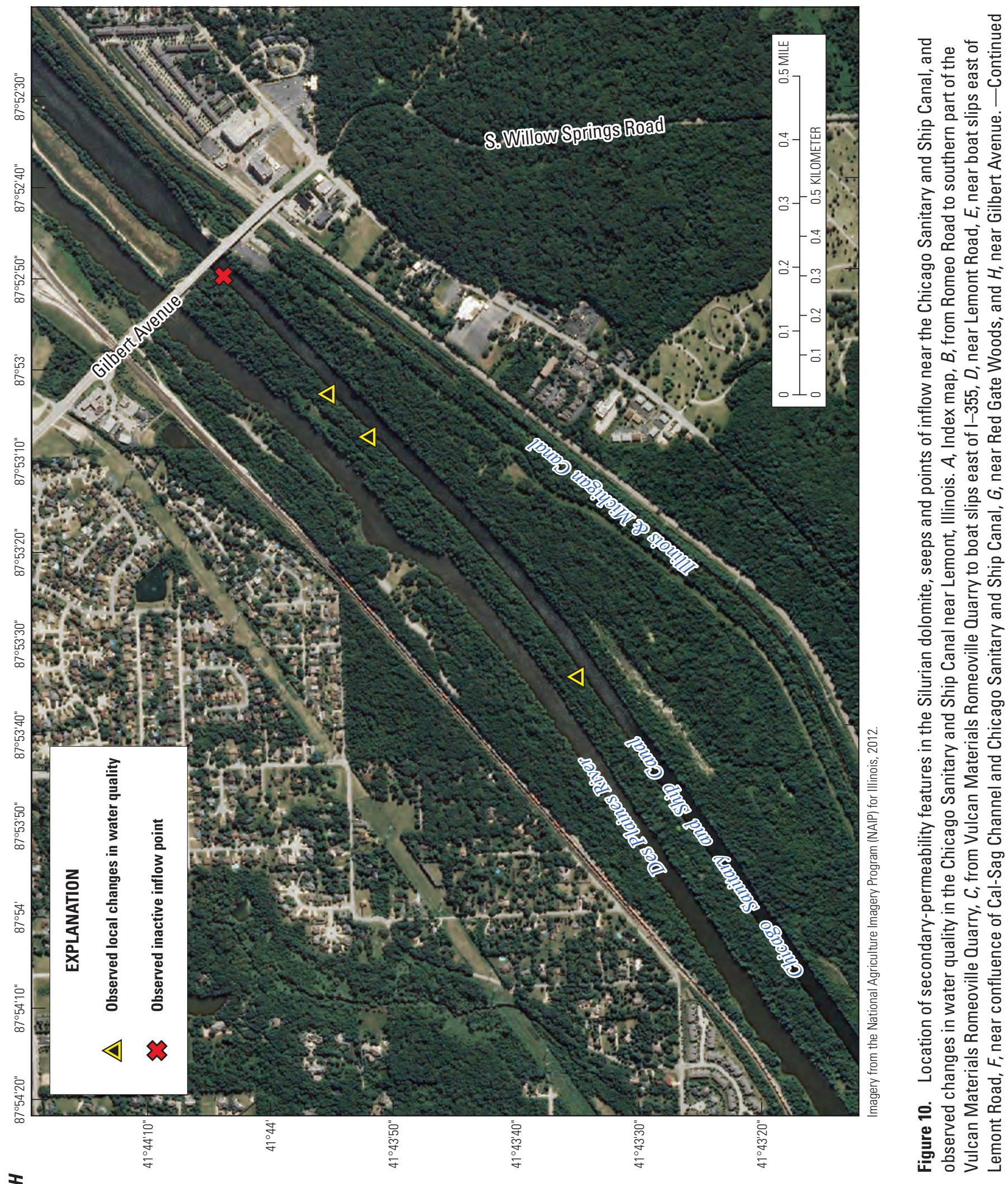



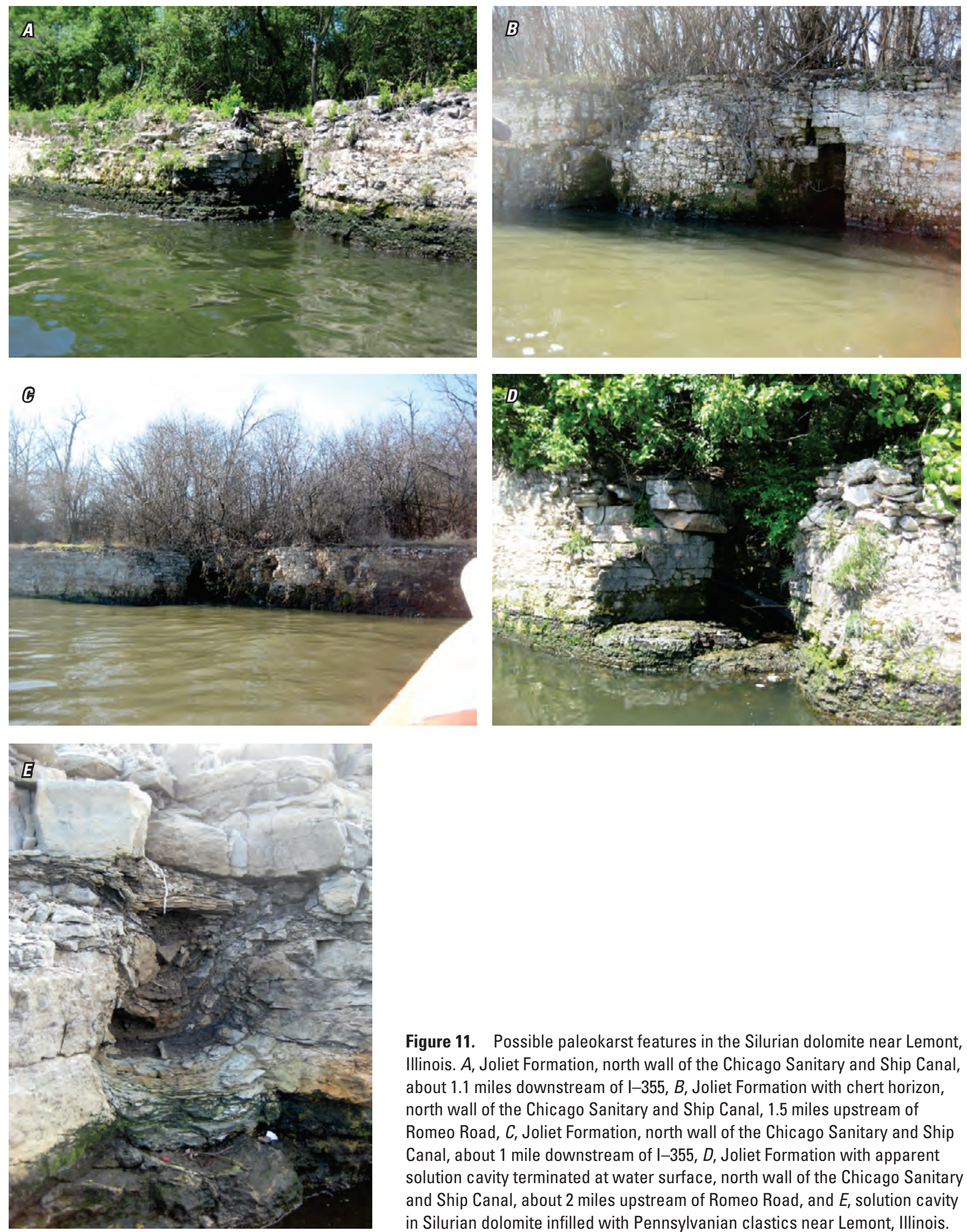

Figure 11. Possible paleokarst features in the Silurian dolomite near Lemont, Illinois. $A$, Joliet Formation, north wall of the Chicago Sanitary and Ship Canal, about 1.1 miles downstream of I-355, $B$, Joliet Formation with chert horizon, north wall of the Chicago Sanitary and Ship Canal, 1.5 miles upstream of Romeo Road, $C$, Joliet Formation, north wall of the Chicago Sanitary and Ship Canal, about 1 mile downstream of I-355, $D$, Joliet Formation with apparent solution cavity terminated at water surface, north wall of the Chicago Sanitary and Ship Canal, about 2 miles upstream of Romeo Road, and E, solution cavity in Silurian dolomite infilled with Pennsylvanian clastics near Lemont, Illinois. 
surface is low in most of the area from site 2 to beyond the eastern edge of the study area (fig. 8) (Hill, 1896; U.S. Army Corps of Engineers, 1978, 2010; STS Consultants, Ltd., 2002; V3 Companies, Ltd., 2008; William Morrow, U.S. Geological Survey, written commun., 2011). Unconsolidated deposits also tend to be thicker near the DPR than near the CSSC in much of the study area.

In most of the study area between Romeo Road and DC-resistivity survey site 2 , the elevation of the bedrock surface exceeds $580 \mathrm{ft}$ NAVD 88, and the unconsolidated deposits typically consist of fill, including silty clay, sand, and dolomite boulders up to $3 \mathrm{ft}$ in diameter. From about DC-resistivity survey site 2 to the eastern edge of the study area, the elevation of the bedrock surface is more variable and typically is less than $580 \mathrm{ft}$. Fill deposits up to about $15 \mathrm{ft}$ thick also are present in this area. Fill materials are derived primarily from excavation of the CSSC and IMC. The fill deposits are present at sporadic locations between the DPR, CSSC, and IMC in much of the study area, but long, continuous deposits up to about $15 \mathrm{ft}$ above grade were emplaced as a levee near the southern bank of the DPR in much of the study area. Fill for the levee along the south bank of the DPR is one of the reasons the unconsolidated deposits tend to be thicker near the DPR than near the CSSC.

In most of the study area from DC-resistivity survey site 2 to the area east of DC-resistivity survey site 1, the bedrock surface is lower near the DPR than it is near the CSSC (see the area near sites 2 and 1 and next to Kingery Highway in figure 8). Erosion of the bedrock surface along the current and historical path of the DPR has resulted in the natural deposition of sand, silt, and clay along the DPR, which is a second reason unconsolidated deposits tend to be thicker near the DPR than near the CSSC.

From DC-resistivity survey site 2 to beyond the eastern edge of the study area, the thickness of the natural (not fill) unconsolidated deposits shows an overall increase. In this area the natural unconsolidated deposits consist of thick (typically in excess of $30 \mathrm{ft}$ ), omnipresent, fine-grained glacial and fineto-coarse-grained alluvial deposits, with the exception of a small area near Kingery Highway where the unconsolidated deposits are thin (less than $5 \mathrm{ft}$ ) or absent at the DPR (fig. 8). Owing to this increase in the thickness of the unconsolidated deposits, the walls of the CSSC are completely incised into unconsolidated deposits east of about Willow Springs (Appendix 2).

On the basis of these observations, the potential for Asian carp eggs and (or) larvae to travel from the DPR to the CSSC within the area of interest east of about DC-resistivity survey site 1 is considered to be very low because the unconsolidated deposits would likely filter out eggs discharged from the DPR before they entered the CSSC. As a consequence, the bulk of the remainder of this investigation concentrated on hydraulic characterization within the study area (fig. 2) located from direct current resistivity survey site 1 (fig. 3) about 1 mi northeast of Kingery Highway west to the electric fish barrier.

\section{Hydrology}

Understanding the hydrology of the surface-water bodies within the study area, and the interaction between these bodies and the intervening groundwater system, is essential to assessing the potential for the interbasin transfer of Asian carps by the groundwater pathway.

\section{Des Plaines River}

\section{Stage and Discharge}

Monitoring of stage and discharge of the DPR at gage 05533600 began in 2010 and continued beyond the end of data collection for this investigation (November 30, 2011) (fig. 2). Stage measurements on the DPR at gage 05533600 during the investigation typically trended toward a base level of $584 \mathrm{ft}$ NAVD 88 but increased by as much as about $6 \mathrm{ft}$ in response to snowmelt and precipitation events, particularly the rainfall events of more than 1 in. that occurred in late May, early June, and late July 2011 (fig. 12).

Discharge on the DPR at gage 05533600 during the investigation trended toward a base level of about 225 cubic feet per second $\left(\mathrm{ft}^{3} / \mathrm{s}\right)$ but increased to more than $3,000 \mathrm{ft}^{3} / \mathrm{s}$ in response to a number of snowmelt and precipitation events (fig. 13). Periodically, the stage of the DPR rises high enough to result in the flow of water from the DPR to the CSSC in parts of the area of interest (fig. 14). This flow occurs principally as overland flow in topographically low areas, but it also occurs as subsurface flow through small thicknesses (less than about $3 \mathrm{ft}$ ) of boulder-sized fill material and weathered bedrock overlying more competent bedrock. These pathways are collectively referred to as "near-surface flow pathways" in this report. The potential for interbasin spread of Asian carps by way of overland flow has been reduced by the installation of a fence in 2010 by the USACE along the south bank of the DPR.

\section{Bathymetry}

Bathymetric surveys of the bed of the DPR were done by the USACE along 200 cross sections from about $3.5 \mathrm{mi}$ downstream of Romeo Road to gage 05532500 (fig. 2) (David Waterman, University of Illinois, written commun., 2011). The survey interval was variable but averaged about 1 cross section every 0.2 river mile. The raw bathymetric data were processed by the USGS to determine the elevation of the lowest point of the bed of the DPR along each transect, which was extrapolated throughout the survey area (fig. 15).

The lowest point on the bed of the DPR decreased from about $595 \mathrm{ft}$ NAVD 88 in the eastern part of the survey area at gage 05532500 to about $583 \mathrm{ft}$ where the DPR and the CSSC begin to flow parallel to each other approximately at river mile 24.3 (fig. 15) just west of Stickney (fig. 2). From river mile 24.3 to about river mile 9 west of I-355, the lowest point of 


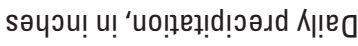

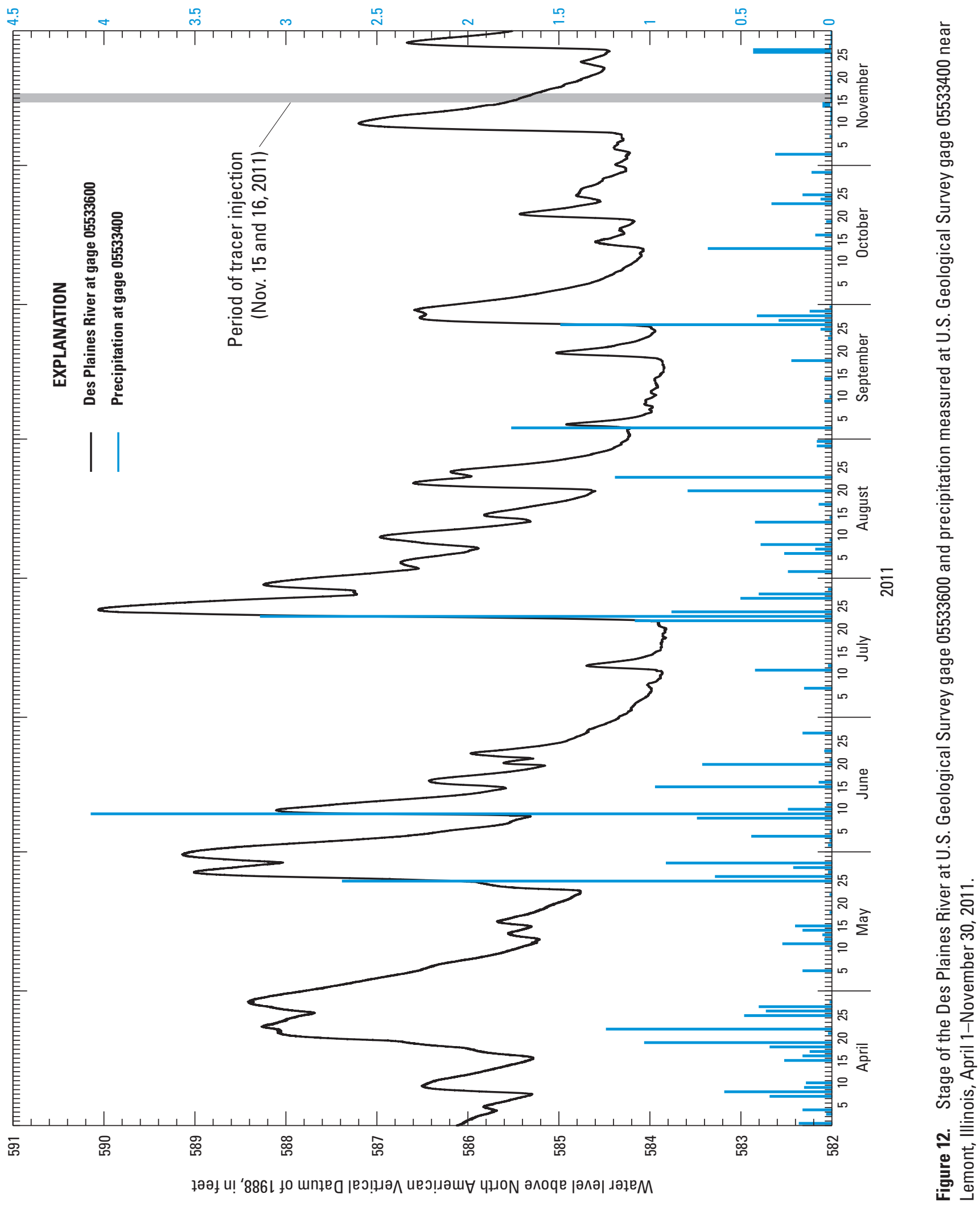




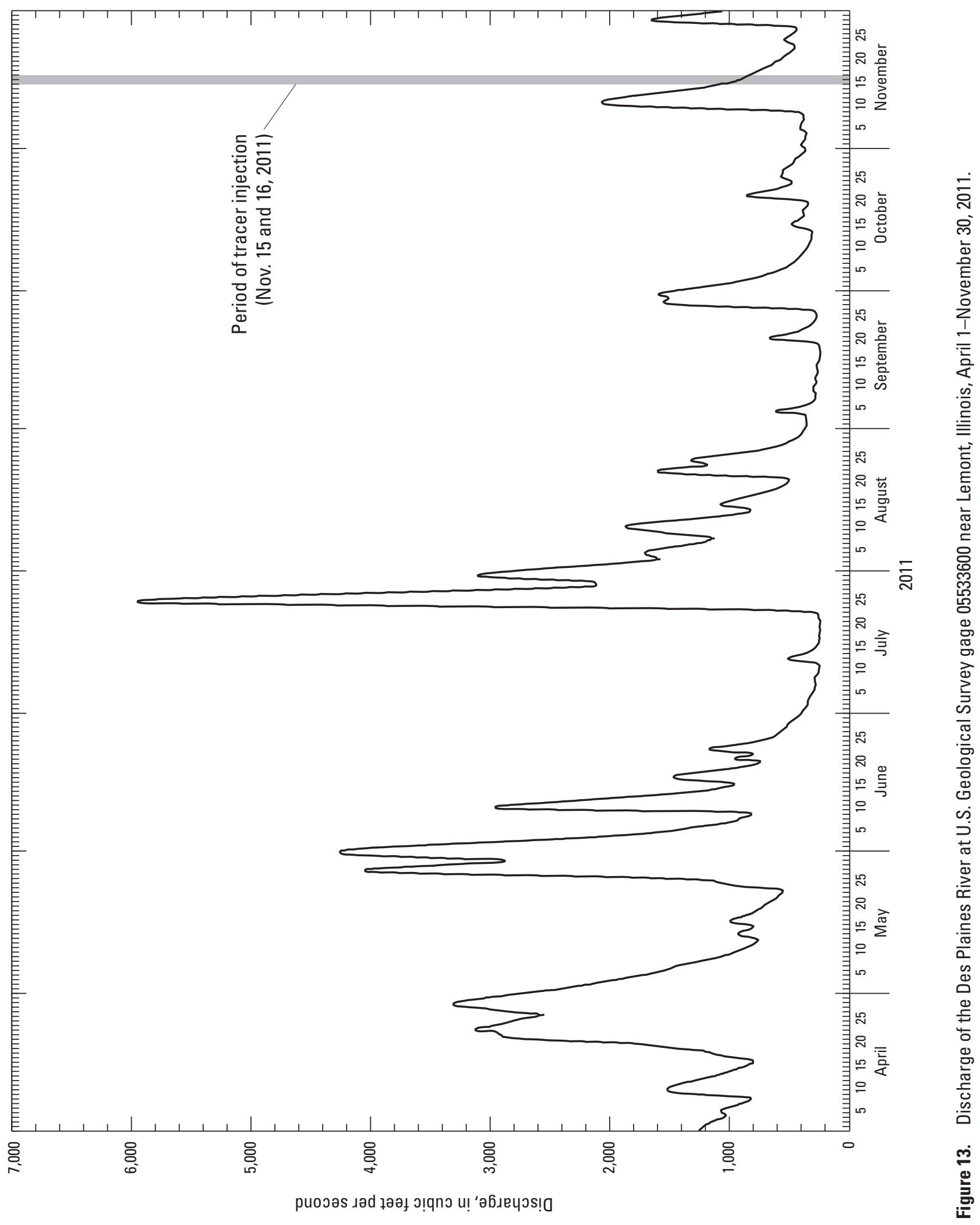



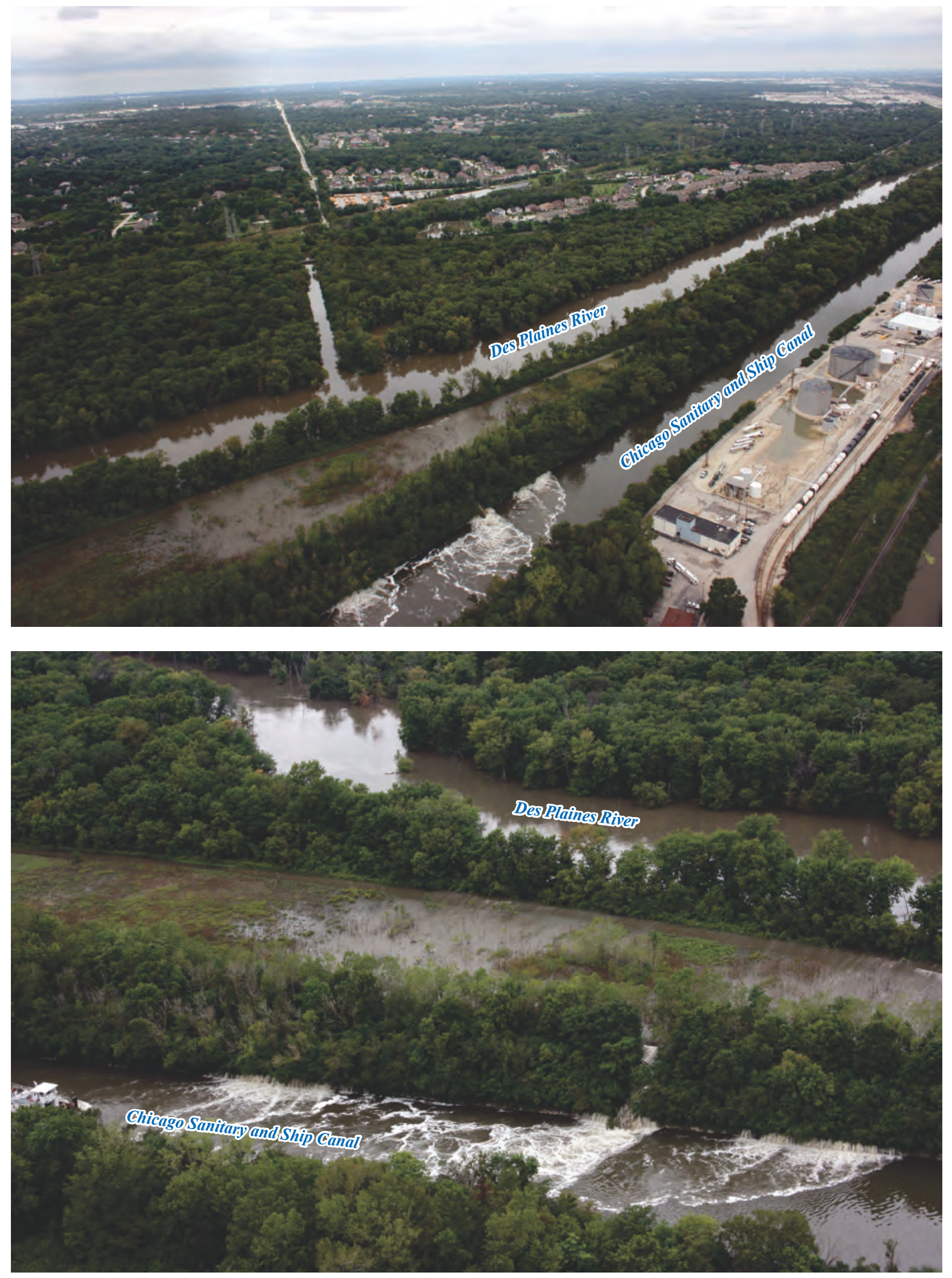

Figure 14. Flood flow from the Des Plaines River to the Chicago Sanitary and Ship Canal near Willow Springs Avenue, September 15, 2008 (photographs by Thomas Minarik, Metropolitan Water Reclamation District of Greater Chicago, copyright Metropolitan Water Reclamation District of Greater Chicago 2012-02, reproduced with permission). 


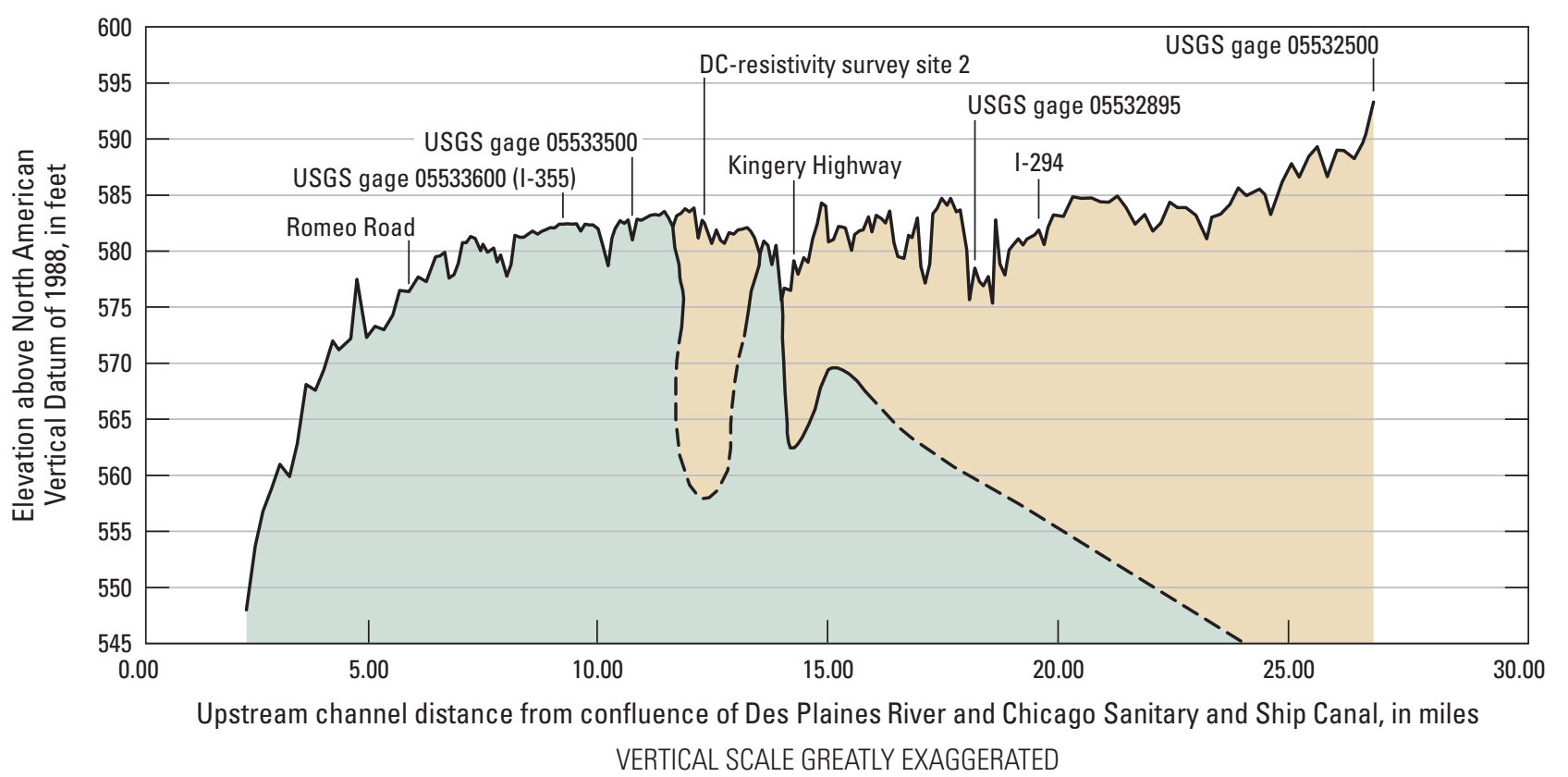

EXPLANATION

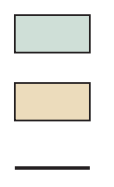

Dolomite

Unconsolidated

Contact—Dashed where approximately located

Figure 15. Elevation of the lowest point of the bed of the Des Plaines River along lines of transect, Riverside to Lockport, Illinois.

the bed of the DPR typically has an elevation between about 585 and $581 \mathrm{ft}$. Within this reach, however, are areas near Kingery Highway and gage 05532895 where the elevation of the lowest point on the riverbed decreases to about $575 \mathrm{ft}$. West of I-355, the elevation of the lowest point on the bed of the DPR begins to decrease to about $576 \mathrm{ft}$ near Romeo Road then continues to decrease to about $550 \mathrm{ft}$ at the end of the survey near Lockport.

The elevation of the lowest point of the bed of the DPR is above $575 \mathrm{ft}$ NAVD 88 within the area of interest (that part of figure 15 upstream of Romeo Road). Comparison of the elevation of the bottom of the DPR (fig. 15) with the elevation of the bedrock surface (fig. 8) indicates that the elevation of the bed of the DPR is approximately equal to the elevation of the bedrock surface east (downstream) of DC-resistivity survey site 2 and perhaps the area about $0.25 \mathrm{mi}$ west of Kingery Highway. In most of the area from DC-resistivity survey site 2 to the eastern edge of the area of interest, there are at least $5 \mathrm{ft}$ of unconsolidated deposits between the base of the DPR and the top of the bedrock. These data provide some preliminary indication of where the bottom and sides of the DPR are likely to be in direct contact with the bedrock.

\section{Composition of Bed Material}

Field surveying of the composition of the DPR bed material was not conducted more than about 1 mi northeast of Kingery Highway because the unconsolidated geologic materials east (and in places west) of this area have interconnected pore spaces that are too small to allow carp eggs with a diameter greater than 0.13 in. to move out of the DPR. The bed of the DPR northeast of the survey area is composed of sequences of fine-grained materials such as the $11.5-22.5 \mathrm{ft}$ of silt, sand, organic materials, and silty clay identified in the immediate vicinity of the McCook Reservoir (STS Consultants, Ltd., 2002) and the fine-grained alluvium identified in the DPR bed in the eastern part of the area surveyed for this investigation (fig. 16).

From a few hundred feet west of Kingery Highway to the Red Gate Woods area, the bed material in the DPR primarily consists of a weathered bedrock or alluvial sand and gravel (fig. 16). Weathered bedrock constitutes the bed material of the DPR in a small (few hundred feet) area near Kingery Highway (Environmental Resources Management-North Central, Inc., 1992a, b). Sand and gravel is the predominate bed material east of Kingery Highway. 


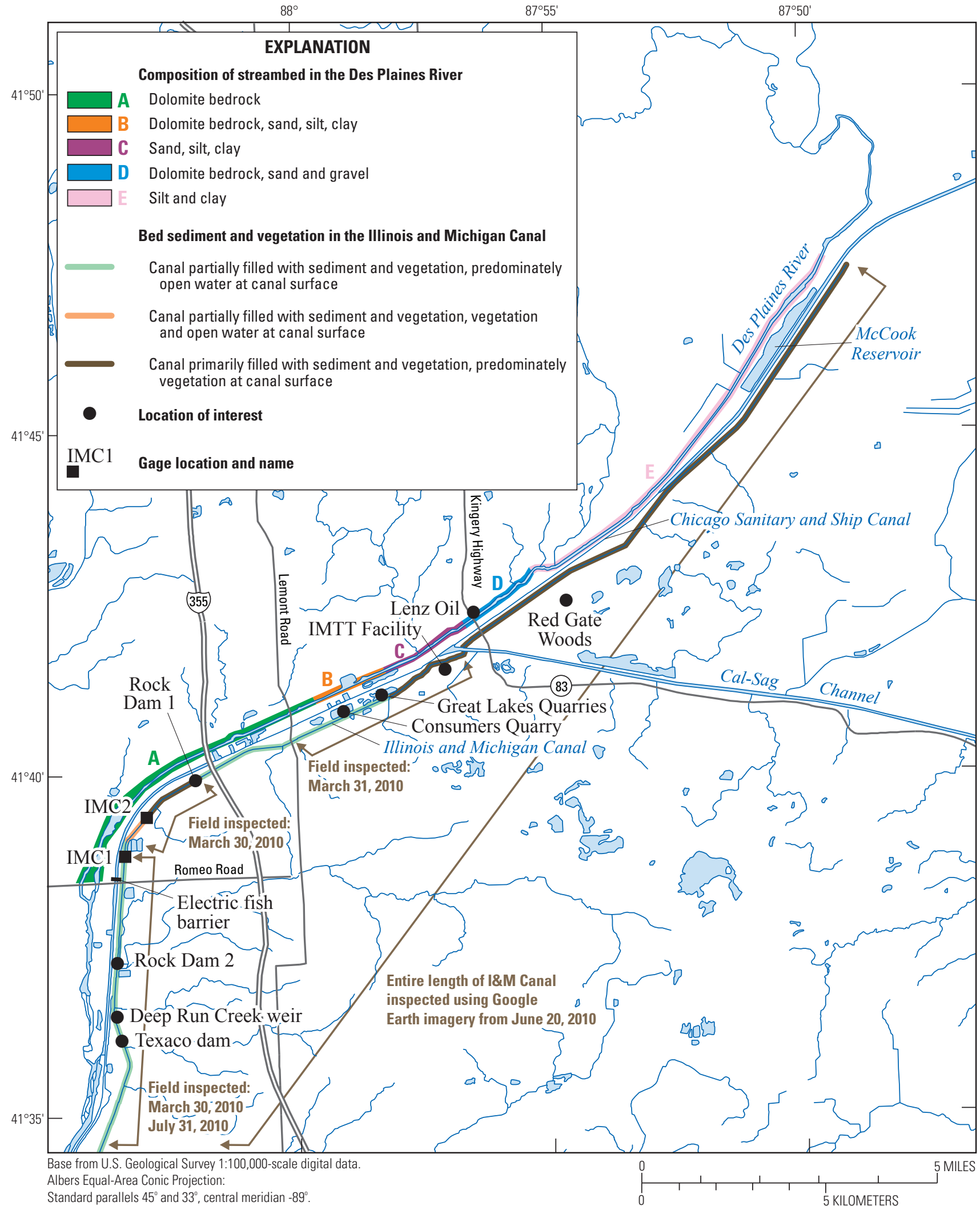

Figure 16. Composition of streambed in the Des Plaines River and degree of infilling of the Illinois and Michigan Canal near Lemont, Illinois. 
From a few hundred feet west of Kingery Highway to the approximate midpoint between Kingery Highway and Lemont Road, the bed material consists of a foot or more of fine-grained alluvium (fig. 16). The riverbed and riverbank are increasingly composed of dolomite west of this reach and consist largely or entirely of dolomite bedrock from about 0.6 mi east of Lemont Road to Romeo Road (figs. 15, 16).

Although the spatial distribution of the sediment composition is expected to vary somewhat in response to the continual changes in the river hydraulics, the sediment data and field surveys at the DPR support the conclusions drawn from evaluation of the geology. There is minimal potential for Asian carp eggs, larvae, and fry to spread from the DPR to the CSSC outside of the study area because of filtration by bed sediments in the DPR and the geologic material between the DPR and the CSSC. These data further indicate that the area of greatest potential for interbasin spread of Asian carps from the DPR to the CSSC by way of groundwater is in the western part of the study area where the bottom of the DPR is in direct contact with the dolomite bedrock.

\section{Illinois and Michigan Canal}

The stage of the IMC was monitored from October 2007 through July 2012 (typically semiannually in April and October) by a consulting firm at gages IMC1 and IMC2 located about 0.5 and $1.75 \mathrm{mi}$, respectively, north of Romeo Road (Tom Nissen, Trihydro Corporation, written commun., 2012; fig. 16). Stage measurements on the IMC at these gages ranged from 577.9 to $579.2 \mathrm{ft}$ NAVD 88. The geometric mean value of the stage at both gages was $578.7 \mathrm{ft}$, indicating a low hydraulic gradient in this area.

The low hydraulic gradient on the IMC is partly due to the presence of two water-flow control structures located 2-3 mi downstream of Romeo Road (Demissie and Xia, 1990) and a control structure about 2.4 mi upstream of Romeo Road. These structures are the rock dam 1, the Texaco dam, and the Deep Run Creek weir (figs. 2, 17A-D). Rock dam 1 was installed by the USACE in 2010 as a barrier to carp movement on the IMC. Rock dam 1 has a top elevation of about $588 \mathrm{ft}$ NAVD 88, which is the approximate elevation of the surrounding land surface. The Texaco dam has a top elevation of $578.06 \mathrm{ft}$ NAVD 88. Texaco dam has been closed and non-operational since possibly the late 1980s. The weir has a top elevation of $577.50 \mathrm{ft}$ NAVD 88 and permits floodwaters transmitted down the IMC to overflow into Deep Run Creek, which is between the IMC and the CSSC south of the weir.

The typical 2-3 ft (approximate) difference in stage in the IMC above and below the Texaco dam, along with the dam structure and its overlying catwalk, is likely to prevent the upstream movement of Asian carps in the IMC under most conditions. A 2-3 ft high rock dam 2 (figs. 2, 17E, F) across the IMC about 0.75 mi upstream of the Deep Run Creek weir should further impede the upstream movement of carp under low-stage conditions. However, hydraulic modeling by Demissie and others (1994) indicates that the stage of the
IMC near Lockport could exceed the height of the Texaco dam under conditions of a 50-year, 24-hour storm. ${ }^{1}$ Under such circumstances, it might be possible for Asian carps to move upstream of the dam.

To evaluate the possibility of flood-stage waters being high enough to overtop the Texaco dam from 1994 - the earliest possible date for Asian carps to be in this area (Kolar and others, 2007) - to November 2011, the hydraulic simulation results of Demissie and others (1994) were further considered. The equivalent precipitation depth under the simulated storm condition (50-year, 24-hour) was 6.46 in. A review of data from precipitation gages in the CSSC drainage basin indicates that from 1994 to November 2011, the 24-hour precipitation totals in the Lemont area never exceeded 6 in. Field inspection of the IMC canal on July 31, 2010, during a period in which more than 5 in. of rainfall fell in the 10 days preceding the survey, indicated that the water level in the IMC upstream of the Texaco dam was about $3 \mathrm{ft}$ higher than below the dam and that the dam was not submerged. However, rock dam 2 was submerged on this date (figs. 17B, D, F). Conditions at rock dam 1 were not observed on this date; however, modeling indicates that the stage of a 100-year flood ${ }^{2}$ at this dam would be about $3 \mathrm{ft}$ below the top of the dam (Richard Ackerson, U.S. Army Corp of Engineers, written commun., 2012), so even if Asian carps were to circumvent the Texaco dam, rock dam 1 would likely define their maximum extent of travel in the IMC.

Since cessation of transportation operations in 1933 the IMC has been infilling with sand, silt, and clay-sized sediment and vegetation (fig. 18). Bathymetric surveys were not made on the IMC because of accessibility and safety concerns, but the depth of the water in the IMC is likely to be less than $4 \mathrm{ft}$, and typically less than $2 \mathrm{ft}$, within the study area.

Field surveys done in March and July 2010 and evaluation of aerial photographs taken on June 20, 2010, indicate the continuous or near-continuous presence of open water on the IMC from the Texaco dam to about $1.1 \mathrm{mi}$ north-northeast of the electric fish barrier and from about 0.25 mi west of I-355 to the western part of the Great Lakes Quarries (figs. 16, 18). The IMC is dammed to form impoundments to collect stormwater runoff at the IMTT facility (KPRG and Associates Inc., 2004), and there are a number of culverts between the IMC and the CSSC within a few hundred feet south of IMTT (Rick Ackerman, U.S. Army Corps of Engineers, written commun., 2012). Dense accumulations of sediment and cattails, with little to no standing water, filled the IMC in much of the middle third of the reach between Romeo Road and I-355 and from the eastern part of the Great Lakes Quarries to the Cal-Sag Channel. However, field inspections after heavy precipitation events in late July 2010 indicated that the typically dry areas of the IMC between Romeo Road and I-355 were water filled.

\footnotetext{
${ }^{1}$ Total rainfall over 24 hours with a recurrence interval of 50 years (that is, a 2-percent probability of being equaled or exceeded in any given year).

${ }^{2}$ Peak flood discharge with a recurrence interval of 100 years (that is, a 1 -percent probability of being equaled or exceeded in any given year).
} 

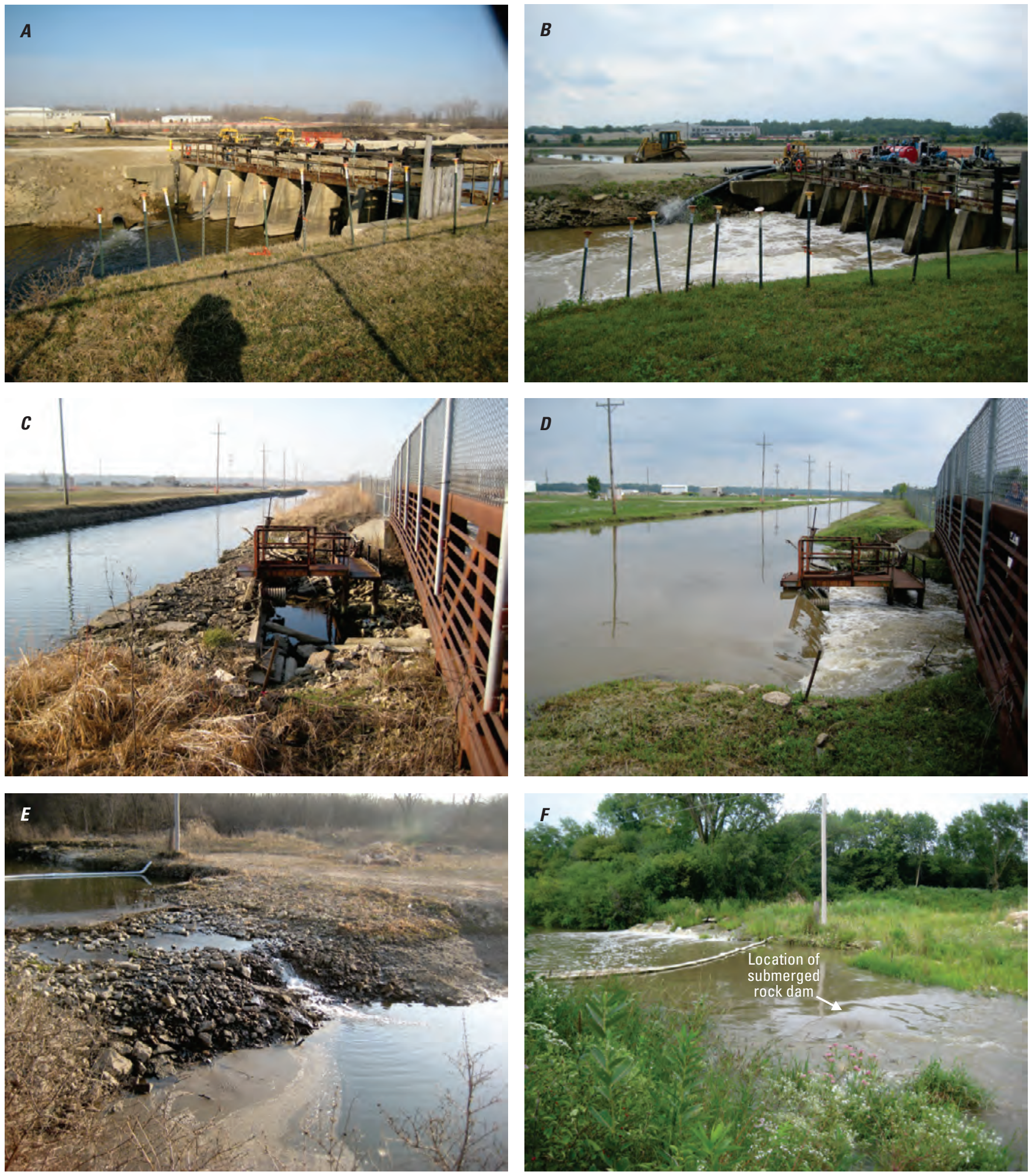

Figure 17. Barriers to Asian carp spread along the Illinois and Michigan Canal near Lockport, Illinois. $A$, Texaco dam, 2.7 miles downstream of Romeo Road, March 30, 2010, B, Texaco dam, July 31, 2010, C, Deep Run Creek weir, 2.0 miles downstream of Romeo Road, March 30, 2010, D, Deep Run Creek weir, July 31, 2010, E, rock dam 2, 1.3 miles downstream of Romeo Road, March 30, 2010, and $F$, rock dam 2, July 31, 2010. 

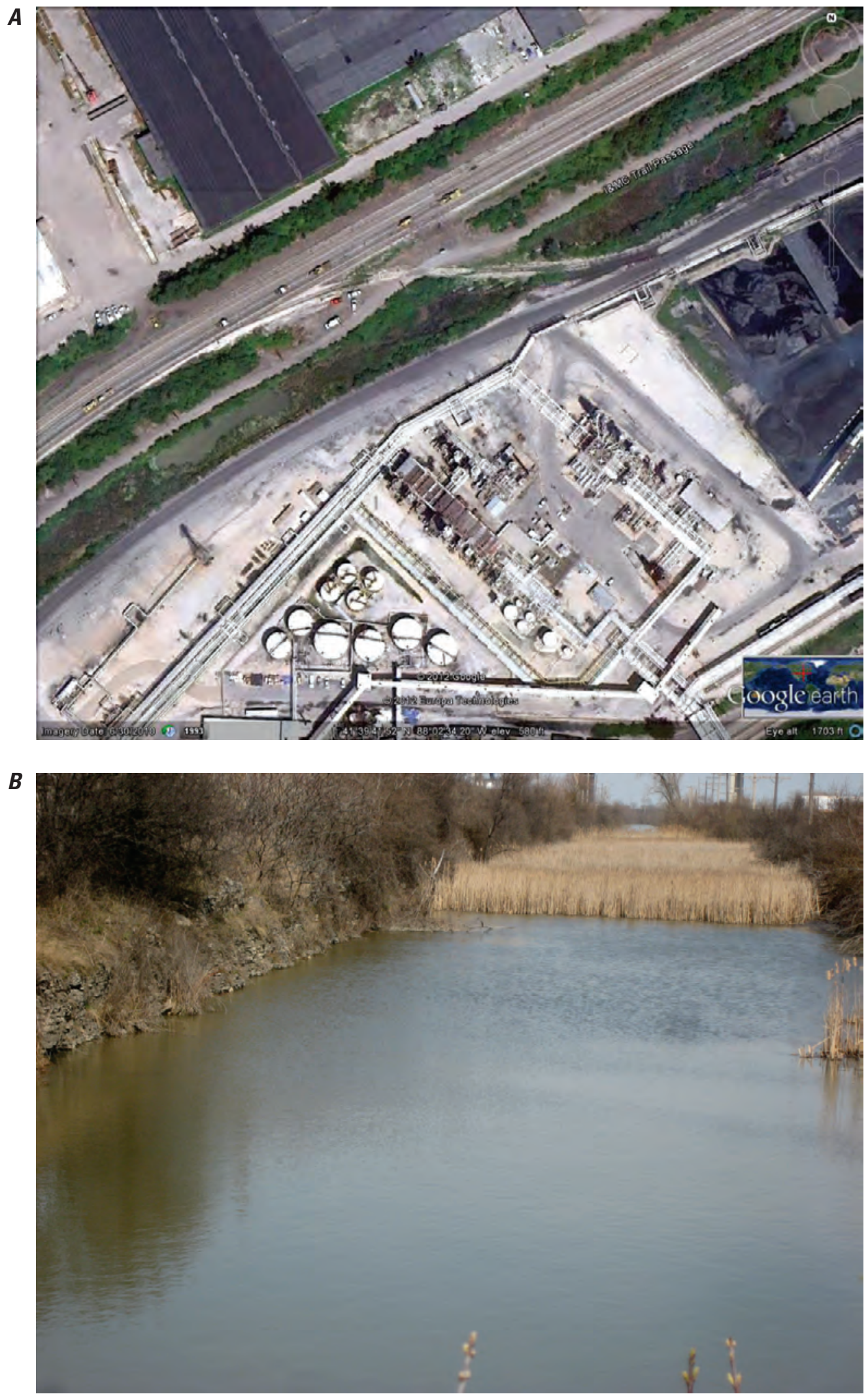

Figure 18. Sediment and vegetation infilling of the Illinois and Michigan Canal near Lemont, Illinois. $A$, Aerial view, about 1.8 miles upstream of Romeo Road, June 30, 2010, and B, Canal-level view, March 30, 2010. 
Because the Texaco dam forms a substantial barrier to the potential spread of Asian carps into the IMC during even the most extreme precipitation events, the potential for Asian carps to spread into the IMC north of the dam is considered minimal. However, because silver carp are capable of jumping several feet out of the water, the potential for at least silver carp to circumvent the dam (although small) cannot be discounted. If the carp were able to breach the Texaco dam they would likely be able to spread north of rock dam 2 during high-water events, but their spread would likely be blocked by rock dam 1. Rock dam 1 is northeast (upstream) of the electric fish barrier, indicating the potential for spread from the IMC to the CSSC upstream of the fish barrier by way of the groundwater pathway. Even if the carp were able to spread to rock dam 1, the small amount of bedrock in contact with the water column above the top of the sediment in the IMC, the apparent absence of large, areally extensive fractures between the IMC and the CSSC, and the absence of a consistently substantial hydraulic gradient capable of driving rapid water movement from the IMC to the CSSC indicates that movement from the IMC to the CSSC by the groundwater pathway is unlikely.

\section{Chicago Sanitary and Ship Canal}

The stage of the CSSC within the study area shows some variation, but it typically was maintained at about $576.7 \mathrm{ft}$ NAVD 88 during the investigation (fig. 19) to facilitate navigation. The stage of the CSSC was often lowered by 2-4 ft for short periods of time during and in advance of precipitation events to accommodate stormwater discharge.

As expected from a constructed feature, the CSSC typically has a rectangular cross section with nearly vertical walls. Numerous small areas where material from the walls of the canal has sloughed into the CSSC (fig. 20A) or sediment was deposited from overland and near surface flow (fig. 20B) were identified from evaluation of the data collected during the MBES survey, but the walls of most of the CSSC have no sediment which could impede invasive-species movement through secondary-permeability features in contact with the canal wall. Evaluation of the MBES data also resulted in the identification of a number of hazards to navigation and the safety of the electric fish barrier, including more than 100 abandoned vehicles and 6 uncharted shipwrecks (fig. 20C, D). The locations of all submerged vehicles and wrecks were provided to the local authorities, the USACE, and the Metropolitan Water Reclamation District of Greater Chicago.

\section{Wetlands and Seeps}

Wetlands are present between the DPR and the CSSC in much of the area of interest southwest of I-355 and from DC-resistivity survey site 2 (fig. 3) to about the western part of the Vulcan Materials McCook Quarry (fig. 2). The wetlands occupy shallow topographic depressions between the DPR and the CSSC or deeper depressions impounded by fill deposits.
The source of water to these wetlands consists primarily of precipitation and smaller amounts of water seeping from the DPR (including seepage of bank storage) through the levee on the CSSC-adjacent bank of the DPR. Direct overland flow of water from the DPR to the wetlands was not observed except during the infrequent extreme flooding events mentioned earlier in the report. Seepage from the DPR being a source of water to these wetlands is supported by observations that (1) the stage of the DPR is higher than that of the wetlands in parts of the study area and (2) seeps through the levee are present on the south (or east) bank of the DPR at a number of locations within the focus area. The persistence of water in these wetlands indicates that they are underlain by lowpermeability dolomite containing few or no near-surface secondary-permeability fractures in most of the area between the DPR and CSSC. Because this water passes through the geologic material at the levee, carp eggs, larvae, and fry are not expected to be able to move from the DPR to the wetlands (except during extreme flooding events). The USACE constructed a barrier fence between the DPR and the CSSC to reduce the potential for overland transfer of Asian carps to the CSSC during flood events.

Field inspections indicate that water from the wetlands discharges along the north or west (DPR adjacent) wall of the CSSC by way of seeps, overland flow, and near-surface flow (figs. 10A-H, 21). This discharge (particularly the seeps and near-surface flow) is continuous or frequently occurring, and it is a separate phenomenon from the occasional discharge to the CSSC caused by flooding of the DPR discussed previously. The flow volume from, and location of, the discharge points was observed to vary with hydraulic conditions in the wetlands, being higher and more numerous, respectively, when water levels in the wetlands are high and the wetlands are spatially extensive.

Seeps and near-surface flow features typically are located in areas where standing water in the wetlands drains to subsurface secondary-permeability permeable features within a few feet of land surface and within several feet of the wall of the CSSC. These secondary-permeability features tend to be small fractures likely created by near-surface erosion from water movement and freeze-thaw cycles. They do not appear to be part of a larger or deeper network of secondary-permeability features in the dolomite.

The seepage location with the highest rate of flow was on top of apparently competent bedrock near the arched pipeline about 0.4 mi upstream of the electric fish barrier (figs. 10B, 21C). The rock above the seep was fractured as a result of construction of a trench for the buried part of the pipeline. Water drainage appears to be through the permeable pathway of rubble excavated into the competent bedrock and does not reflect natural conditions. Smaller amounts of seepage also were observed approximately midway between Romeo Road and I-355 (fig. 22A), in the vicinity of I-355, about $0.25 \mathrm{mi}$ west of Lemont Road, and about 1.4 mi east of Lemont Road (fig. 22B). 
Daily precipitation, in inches

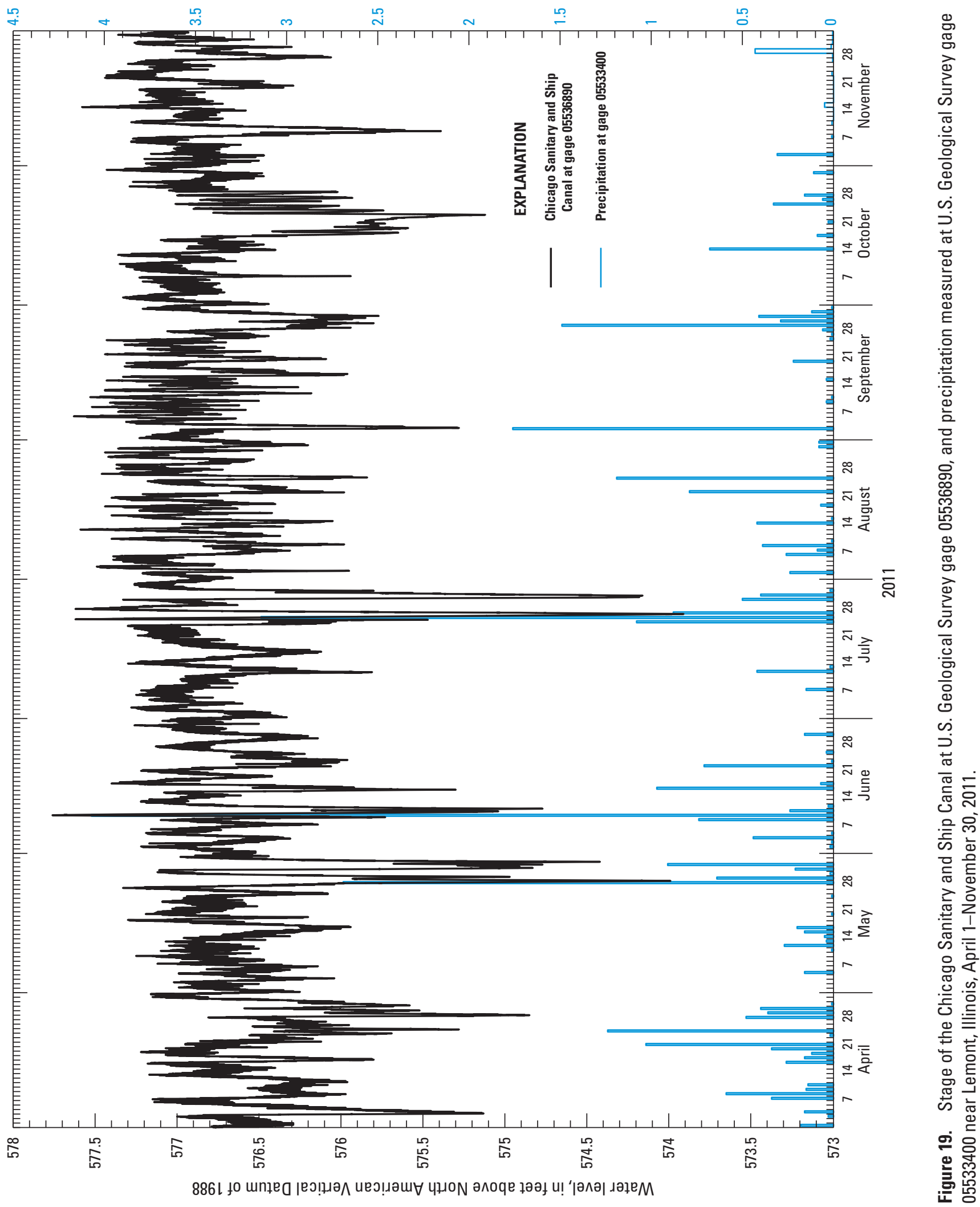




\section{Groundwater}

The hydrogeologic unit of concern to this investigation is the uppermost 60-70 $\mathrm{ft}$ of the Silurian dolomite aquifer. This part of the aquifer is of concern because its elevation encompasses the elevation of the CSSC and extends approximately 20-30 ft lower than the bottom of the CSSC. This elevation is within the maximum probable interval from which particulates (and carp eggs) in the groundwater system could enter the CSSC. Saturated unconsolidated deposits are present within the area of interest, as well as in parts of the study area. However, the unconsolidated deposits do not have sufficiently large pore space to transmit carp eggs and are not discussed further.

Groundwater flow in the Silurian dolomite aquifer is through a massive, low-permeability dolomite matrix that is hydraulically interconnected to networks of transmissive secondary-permeability features embedded within this matrix. The secondary-permeability features identified in this aquifer are primarily vertical and horizontal fractures. Movement of particulates (including eggs, larvae, or small fry) through the aquifer would occur within the fracture network, so any
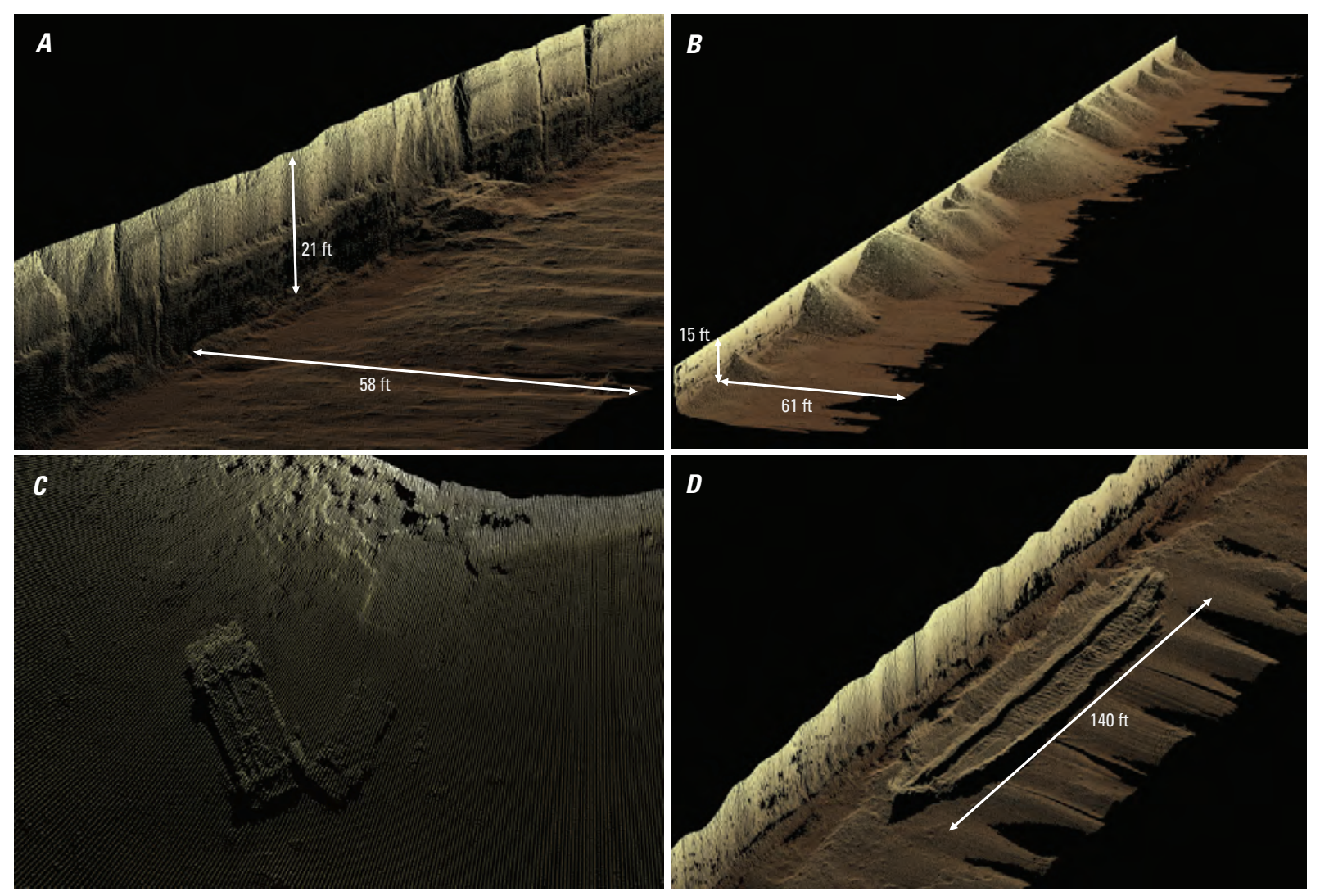

Figure 20. Bathymetry and side-wall view of the Chicago Sanitary and Ship Canal. $A$, Examples of fractures and slab failure in the north wall of the canal approximately 1 mile downstream of I-355, $B$, examples of sediment mounds along the south wall of the canal approximately 0.7 mile upstream of Kingery Highway, $C$, two vehicles in the canal approximately 1 mile upstream of Lemont Road, and $D$, uncharted shipwreck along the south wall of the canal approximately 0.5 mile upstream of Lemont Road. 

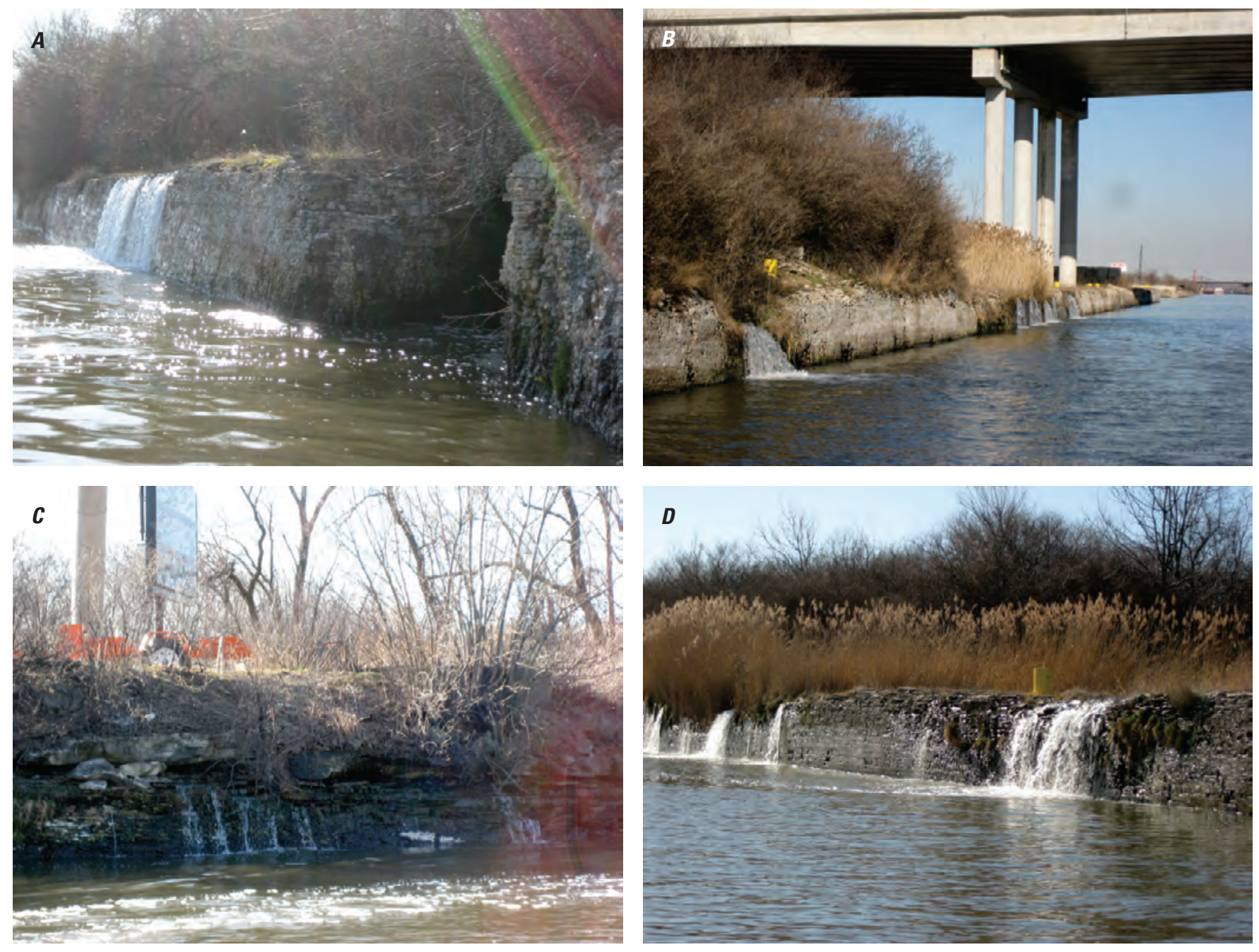

Figure 21. Discharge from wetlands along bedrock surface to the north wall of the Chicago Sanitary and Ship Canal near Lemont, Illinois, March 17, 2010. $A, 1.5$ miles upstream of Romeo Road (note karst-like feature in foreground), $B$, immediately downstream of $\mathrm{I}-355, C$, near pipe arch about 0.1 mile upstream of Romeo Road, and $D, 1.5$ miles downstream of I-355. 
$\boldsymbol{A}$

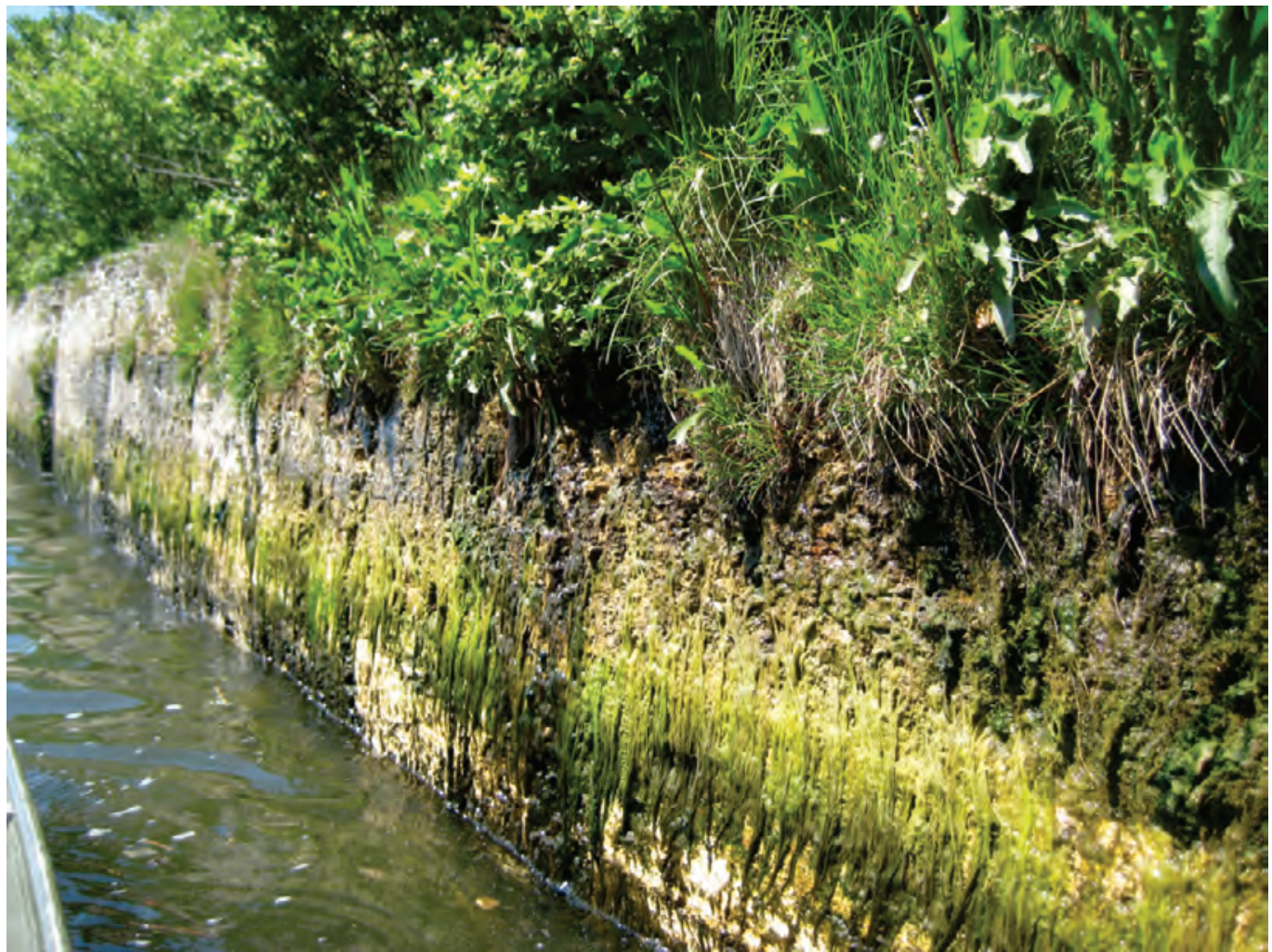

B

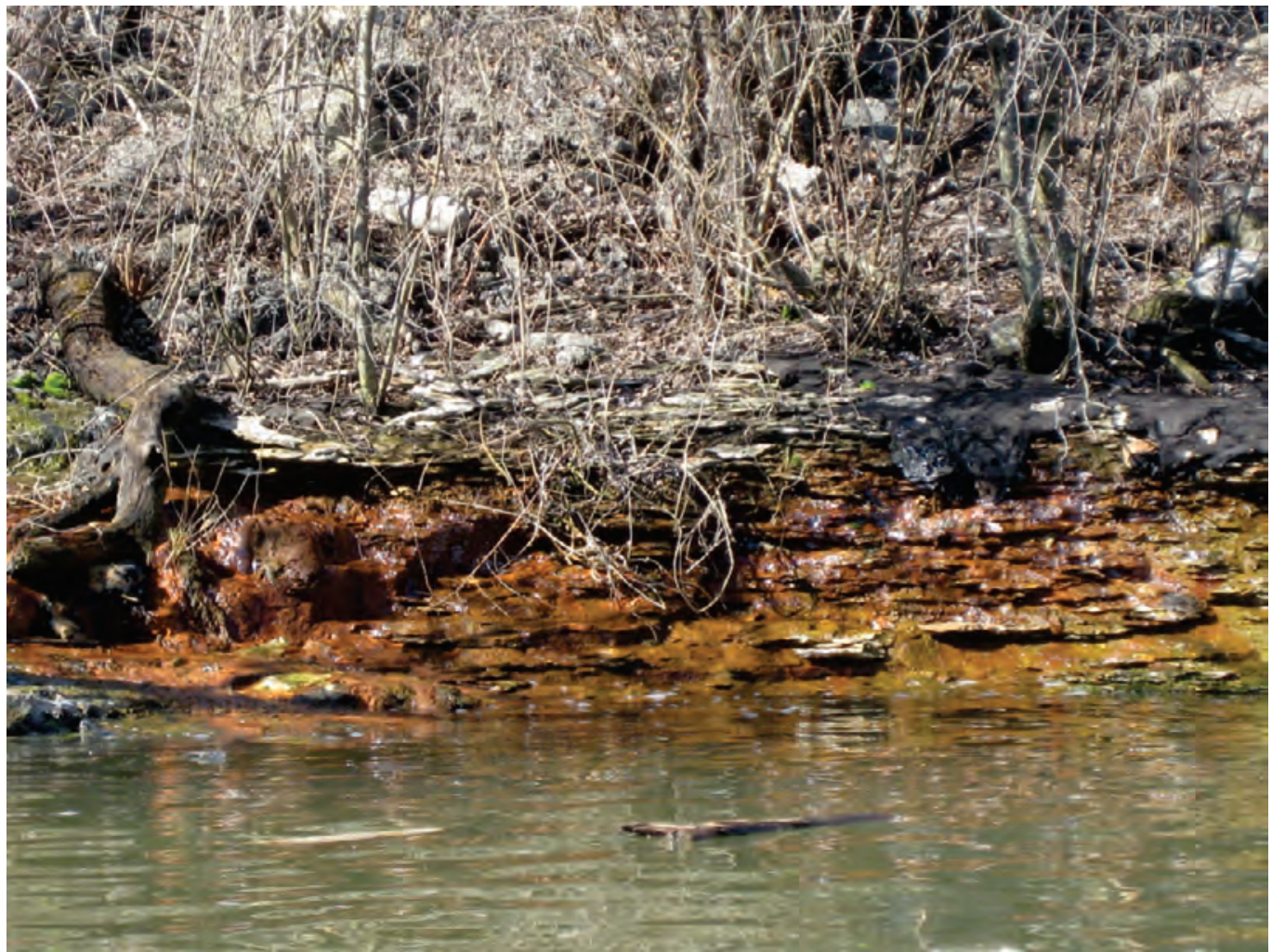

Figure 22. Seeps along north wall of the Chicago Sanitary and Ship Canal near Lemont, Illinois. $A$, In the Joliet Formation, about midway between Romeo Road and I-355, May 4, 2010, and B, in the Sugar Run Formation, about 1.4 miles upstream of Lemont Road, March 17, 2010. 


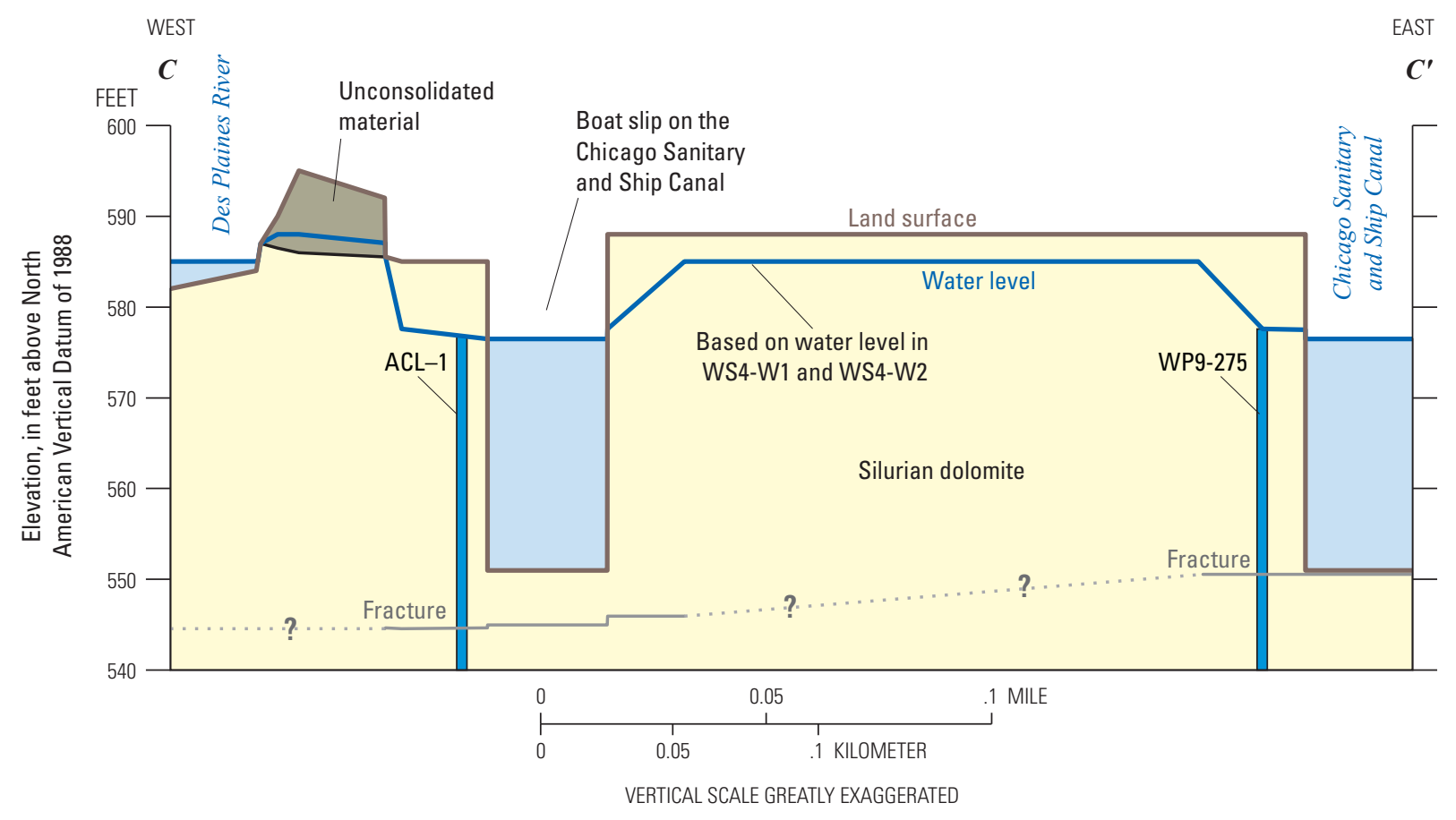

Figure 23. Geologic section $\mathrm{C}-\mathrm{C}^{\prime}$ and inferred groundwater level near Lemont, Illinois (line of section shown in figure 4).

Horizontal hydraulic conductivity $\left(K_{h}\right)$ values obtained from slug tests in wells and test intervals isolated by use of a packer assembly (table 4) in the focus area demonstrate the large differences between the permeability of the unfractured, less permeable parts of the aquifer $\left(2.8 \times 10^{-3}\right.$ to $2.7 \times 10^{-1}$ feet per day) (ft/d) and the fractured, more permeable parts of the aquifer (about 150 to $620 \mathrm{ft} / \mathrm{d}$ ). These values indicate that water movement through the aquifer matrix is likely to be slow but that movement through the fracture at wells WP10-85, WP9-275, and ACL-1 has the potential to be rapid.

Colloidal borescope measurements in wells WP10-85 and WP9-275 confirm that water movement through the horizontal fracture at 546-552 $\mathrm{ft}$ NAVD 88 is rapid. The measurements of flow direction and velocity in the fracture were variable because of responses to water-level fluctuations in the CSSC, including periods of flow reversal. The measurement made during the most stable (optimal) conditions indicates that groundwater velocity was about 10 feet per day (ft/d) at well WP9-275 and that the direction of flow was about 217 degrees from magnetic north (Randall Bayless, U.S. Geological Survey, written commun., 2011), which is from northeast to southwest. This direction is consistent with water flow from the DPR into the groundwater system and from the groundwater system into the CSSC, but it is also consistent with flow from the wetlands near wells WS4-W1 and WS4-W2 to the $\mathrm{CSSC}$ or with regional flow in the Silurian dolomite aquifer into the CSSC.

\section{Implications of Water-Level Data Regarding the Potential for Interbasin Spread of Asian Carps by Way of the Groundwater Pathway}

Continuous and synoptic water-level data at the wells and surface-water gages in the focus area were collected from most or all of the period from April 1 through November 31, 2011 (figs. 25, 26; table 5). These data show nearly identical water levels, and trends in water levels, in wells ACL-1 and WP10-85 and in the CSSC at gage 05536890, which is east (about 2.5 mi upstream) of the focus area (fig. 2). These data indicate a high degree of hydraulic interconnection between the CSSC and the fracture penetrated by these wells (and well WP9-275). Groundwater elevations in wells ACL-1 and WP10-85 were lower than the stage of the CSSC at gage 05536890 , which would indicate that water typically flows from the CSSC to the groundwater system in this area. However, there are multiple lines of evidence (including the presence of seeps on the wall of the CSSC, the typical flow direction provided by the borescope readings, flow profiling in the CSSC near well ACL-1, and the elevated stage of the DPR) indicating that groundwater typically discharges to the CSSC in the study area.

Groundwater elevations in wells ACL-1, WP10-85, and WP9-275 and the stage of the CSSC typically are about $7 \mathrm{ft}$ lower than the minimum stage of the DPR within the study 


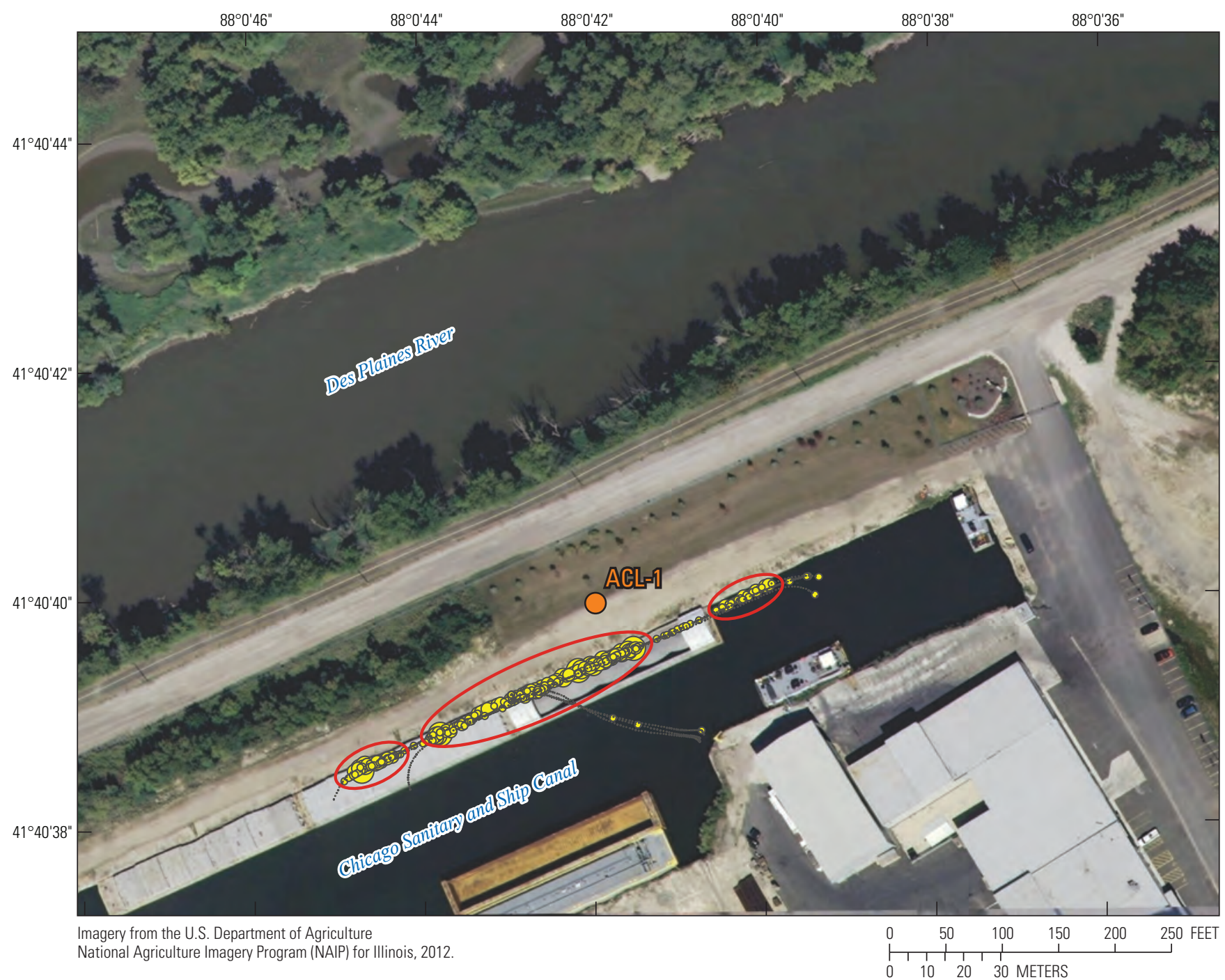

\section{EXPLANATION}

Depth-averaged velocity, 0 to 13 feet above bottom, in feet per second

0 to 0.3

0.3 to 0.6

O $\quad 0.6$ to 0.9

( $\quad 0.9$ to 1.2

1.2 to 1.5

\section{ACLII}

\section{U.S. Geological Survey well location with identifier}

Figure 24. Near-bed depth-averaged velocities measured near the north wall of the ACL slip in the Chicago Sanitary and Ship Canal on December 7, 2010, using an acoustic Doppler current profiler (ADCP). Velocities were averaged over the interval 0 to 13 feet above the bed to capture the depth range of the observed anomalies. Observed velocity magnitudes are likely biased high because of inhomogeneity of the flow and violation of the homogeneous flow assumption by ADCPs. 
Table 4. Horizontal hydraulic conductivity values estimated from slug tests in wells and test intervals isolated by use of a packer assembly near Lemont, Illinois.

[Bold font denotes test done in well; regular font denotes test done in test interval of well isolated by use of a packer assembly; WT, water table]

\begin{tabular}{|ccc|}
\hline Well name & $\begin{array}{c}\text { Tested interval } \\
\text { (feet below land } \\
\text { surface) }\end{array}$ & $\begin{array}{c}\text { Average value of } \\
\text { horizontal hydraulic } \\
\text { conductivity } \\
\text { (feet per day) }\end{array}$ \\
\hline WS4-W2 & $\mathbf{4 . 6 - 6 0 . 2}$ & $\mathbf{0 . 0 0 8}$ \\
\hline WS4-W1 & $\mathbf{3 . 9 - 7 0 . 2}$ & $\mathbf{0 . 0 2 3}$ \\
\hline WP9-275 & $14-24$ & 0.026 \\
\hline WP9-275 & $24-34$ & 0.012 \\
\hline WP9-275 & $34-44$ & 620 \\
\hline WP9-275 & $44-60.2$ & 0.0028 \\
\hline WP10-85 & WT-19 & 0.27 \\
\hline WP10-85 & $19-29$ & 0.0042 \\
\hline WP10-85 & $34-44$ & 330 \\
\hline WP10-85 & $44-61.7$ & 0.004 \\
\hline ACL-1 & $14-24$ & 0.13 \\
\hline ACL-1 & $24-34$ & 0.024 \\
\hline ACL-1 & $39-49$ & 150 \\
\hline ACL-1 & $49-65.4$ & 0.028 \\
\hline
\end{tabular}

area (fig. 25). During high-water events, the stage of the DPR can be as much as about $16 \mathrm{ft}$ higher than the water level in these wells and the stage of the CSSC. These data indicate the continuous potential for water (and particulates entrained in this water) to flow from the DPR to groundwater and from groundwater into the CSSC, with the potential for the fastest, most voluminous flow occurring during high-water events, which are typically when Asian carps spawn (Kolar and others, 2007). However, the absence of correlation between the stage of the DPR and the water levels in wells ACL-1 and WP10-85, even during three distinct high-water events in the DPR during April through mid-June, indicates that-in spite of the hydraulic potential - there is no direct hydraulic communication between the DPR and the fracture at these wells and that the rate of groundwater flow between these features is not rapid.

Both continuous and synoptic water-level measurements indicate the groundwater elevation in wells WS4-W1 and WS4-W2 typically is similar to the stage of the DPR and is always several feet higher than the stage of the CSSC and the groundwater elevation in wells ACL-1 and WP10-85

(figs. 25, 26). These data indicate that the water level in wells WS4-W1 and WS4-W2 is affected primarily by recharge from water in the wetlands surrounding these wells. This recharge may be enhanced in response to precipitation events such as occurred near the end of May 2011. The large difference in water levels between wells WS4-W1 and WS4-W2 and wells ACL-1, WP10-85, and WP9-275 is further indication that wells WS4-W1 and WS4-W2 do not intercept permeable fractures and likely are not close to permeable fractures.

Vertical hydraulic gradients determined from measurements in test intervals isolated by use of a packer assembly in wells ACL-1, WP10-85, and WP9-275 (fig. 4; table 6) indicate complex, fracture-dominated flow within the aquifer. Water levels in the test intervals generally showed an upward gradient between adjacent test intervals if neither test interval intercepted the fracture at about 546-552 ft NAVD 88 in these wells. If a test interval intercepted the fracture, the water level in that test interval almost always had the greatest depth to water. Water-level data indicate that vertical flow in that part of the aquifer above the fracture was down toward the fracture, whereas vertical flow in that part of the aquifer below the fracture was up toward the fracture.

Water-level data from the focus area (table 6; figs. 23, 26) indicate the potential for surface water from the wetlands and perhaps the DPR to recharge the massive, less permeable matrix of the Silurian dolomite aquifer that is present near the DPR in the focus area. Where the aquifer is competent and less permeable, groundwater levels are high, and water flows vertically from the aquifer matrix to the permeable horizontal fracture near the CSSC. Water in this fracture is rapidly transported into the lower part of the CSSC in the focus area. Water-level data provide no indication that water from the DPR recharges the permeable horizontal fracture intercepted by the wells near the CSSC or that it recharges fractures that are in good hydraulic connection with this fracture.

\section{Water Quality}

Water temperature and specific conductance data, in addition to other parameters, were collected during water-quality profiling in the CSSC throughout most of the area of interest in early 2010 (table 1). These data were used to identify areas where groundwater may have been entering the CSSC within the area of interest so as to refine the area of investigation.

Continuous measurements of field parameters (temperature, specific conductance, dissolved oxygen) were made at gage 05536890 on the CSSC, at gage 05533600 on the DPR (fig. 2), and in wells ACL-1, WP9-275, WP10-85, WS4-W1, and WS4-W2 (fig. 4) during at least part of the period from April 1 through November 30, 2011. These data were used to assess the hydraulic interaction between surface water and groundwater in the focus area. 


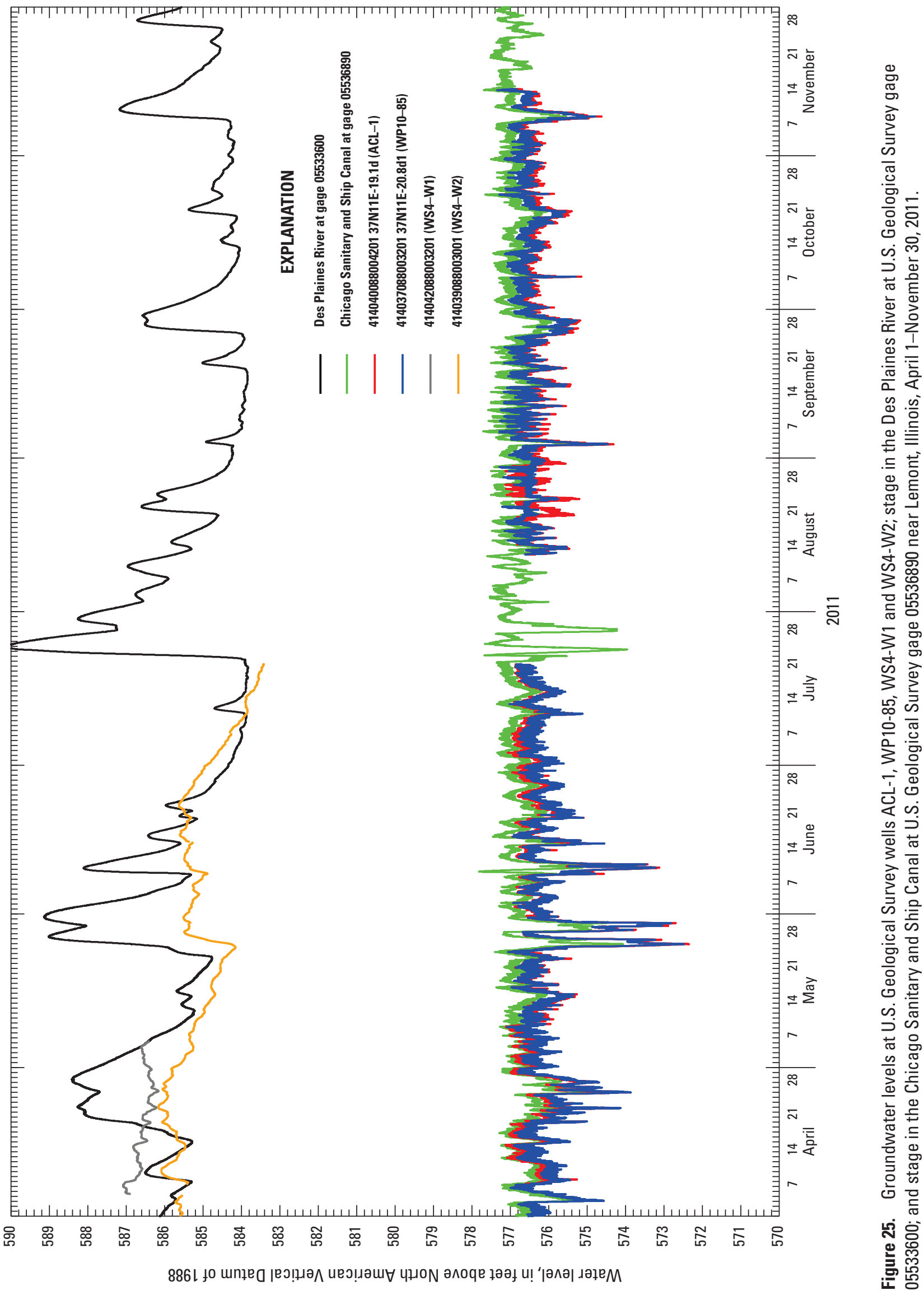




\section{Water-Quality Profiling in the CSSC}

Temperature, specific conductance, dissolved oxygen, $\mathrm{pH}$, turbidity, and depth were measured in the CSSC

from about Romeo Road to Gilbert Avenue/South Willow Springs Road (fig. 2) during the water-quality profiling for this investigation (Appendix 3). These data were collected during February 25-26 and March 2-3, 2010. Temperature and specific conductance data collected by the MWRDGC from the DPR at Ogden Avenue and Material Services Road (fig. 2) also were evaluated to characterize the water quality of the DPR on and near these dates (fig. 27). USGS data collected from the CSSC at Lemont (gage 05536890) at about $10 \mathrm{ft}$ below the water surface also were evaluated. To ensure compatibility of data, temperature, and specific conductance readings taken by the USGS during the water-quality profiling were compared to the values measured at gage 05536890 at the times when the boat passed the gage (fig. 27). The gage and water-quality profiling data are comparable.

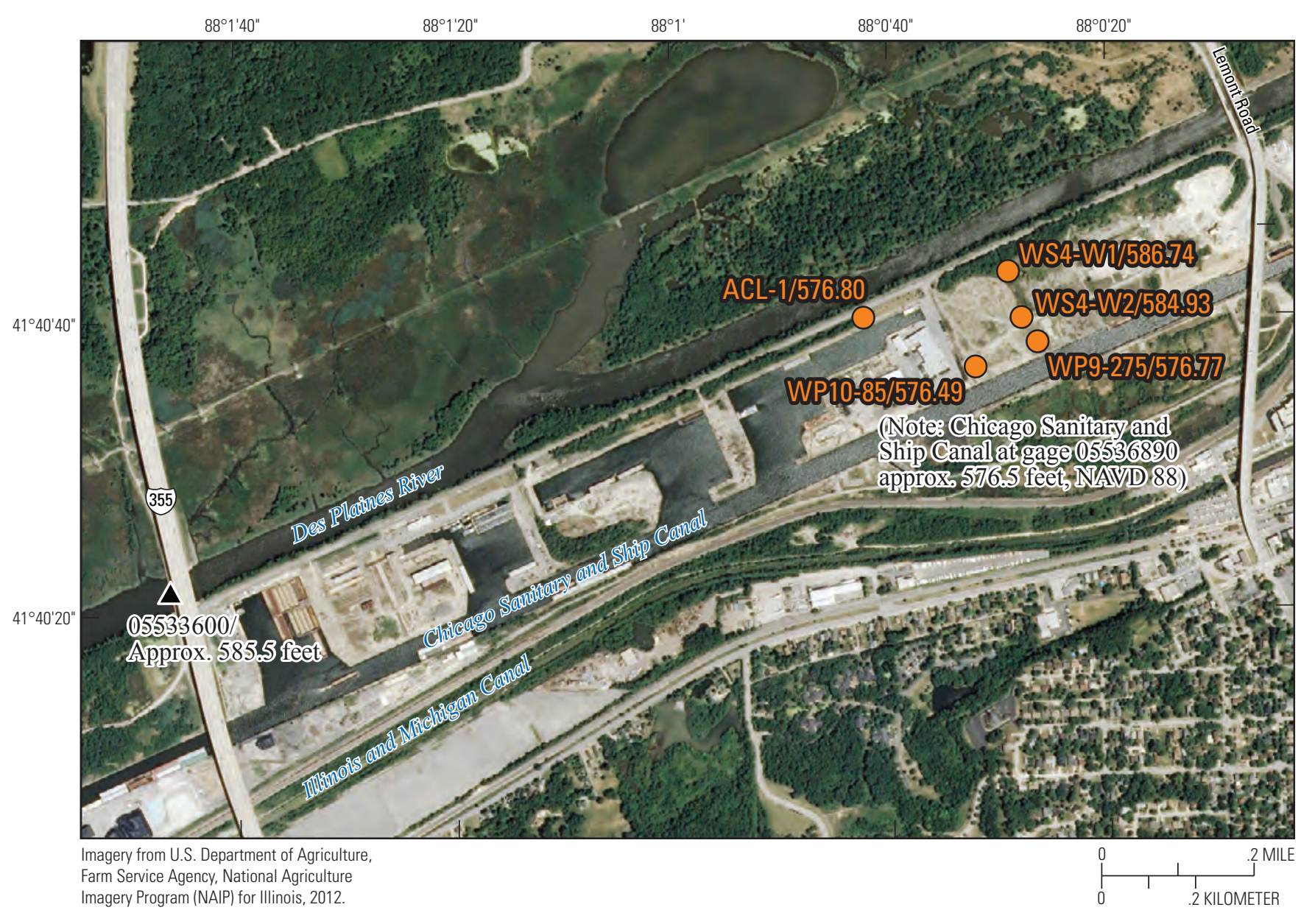

EXPLANATION

ACLON/576:80

$05533600 /$

Approx. 585.5 feet
U.S. Geological Survey well location with identifier and water level above North American Vertical Datum of 1988 (NAVD 88), in feet

U.S. Geological Survey gage with identifier and water level above North American Vertical Datum of 1988 (NAVD 88), in feet

Figure 26. Water levels in wells and stage of surface-water bodies in focus area near Lemont, Illinois, May 9-13, 2011. 
The temperature and specific conductance data showed substantial differences between the CSSC and the DPR during late February and early March 2010 (fig. 27), indicating that these parameters might be suitable indicators of the presence of DPR-influenced water within the CSSC. The DPR was always lower in temperature and typically higher in specific conductance (particularly at Material Services Road) than the CSSC during the survey. Therefore, evaluation of the waterquality data focused on identifying locations of high specific conductance and low temperature in the CSSC within the survey area. Complicating this evaluation was the similarity of the water temperature in the Cal-Sag Channel and DPR. During the survey at the end of February 2010 the Cal-Sag water had a lower specific conductance than the CSSC, but during the survey in early March 2010 the specific conductance of the Cal-Sag water was higher than the CSSC and similar to the DPR.
The ratio of the values of specific conductance and temperature for the water was calculated throughout the survey area (fig. 27) to obtain a more robust indication of areas where groundwater potentially affected by recharge from the DPR was discharging to the CSSC than could be done using the temperature and specific conductance data separately. Areas of the CSSC with a screening ratio above approximately 0.4 were used to identify possible areas of groundwater recharge to the CSSC. The screening ratio was computed for every waterquality profile and plotted, along with temperature and specific conductance, to identify anomalies in the parameters during any profile. Anomalies that occurred in the same location during multiple profiles were given more weight than anomalies that occurred in only a single profile. The depth at which the temperature and specific conductance values were obtained during the profiles also were evaluated to ensure that identified anomalies were not solely due to changes in instrument depth.

Table 5. Groundwater levels near Lemont, Illinois, February 14-November 14, 2011.

[USGS, U.S. Geological Survey; --, no data; NAVD 88, North American Vertical Datum of 1988]

\begin{tabular}{|c|c|c|c|c|c|c|c|c|c|c|c|}
\hline \multirow{3}{*}{$\begin{array}{l}\text { Station } \\
\text { name }\end{array}$} & \multirow{3}{*}{$\begin{array}{c}\text { USGS } \\
\text { site } \\
\text { identifier }\end{array}$} & \multirow{3}{*}{$\begin{array}{c}\text { Measuring- } \\
\text { point } \\
\text { elevation } \\
\text { (feet NAVD 88) }\end{array}$} & \multicolumn{9}{|c|}{$\begin{array}{c}\text { Water-level elevation } \\
\text { (feet above North American Vertical Datum of 1988) }\end{array}$} \\
\hline & & & \multicolumn{9}{|c|}{$\begin{array}{l}\text { Date of measurement } \\
\text { in } 2011\end{array}$} \\
\hline & & & $2 / 14$ & $2 / 18$ & $2 / 24$ & $3 / 23$ & $3 / 30$ & $4 / 5-6$ & $4 / 13$ & $5 / 9$ & $5 / 13$ \\
\hline WS4-W1 & 414042088003201 & 588.26 & -- & 586.71 & 586.85 & 587.01 & -- & 586.88 & 586.67 & 586.74 & -- \\
\hline WP10-85 & 414037088003201 & 589.33 & -- & -- & 576.48 & 575.89 & 576.54 & -- & 576.57 & 576.49 & -- \\
\hline WP7-205 & 414001088022901 & 585.71 & 584.51 & 584.68 & 584.71 & 584.63 & -- & -- & -- & - & -- \\
\hline \multirow[t]{2}{*}{ ACL-1 } & 414040088004201 & 586.58 & 576.39 & -- & -- & -- & -- & -- & -- & 576.80 & 576.17 \\
\hline & & & $6 / 15$ & $6 / 17$ & $6 / 24$ & $7 / 7-8$ & $7 / 21$ & $8 / 12$ & $9 / 8$ & $10 / 14$ & $11 / 14$ \\
\hline WP10-85 & 414037088003201 & 589.33 & -- & 576.53 & -- & 576.43 & 576.93 & 576.52 & -- & 576.37 & 575.68 \\
\hline WP7-205 & 414001088022901 & 585.71 & -- & -- & -- & -- & -- & -- & -- & -- & -- \\
\hline ACL-1 & 414040088004201 & 586.58 & 575.48 & -- & -- & 576.79 & 576.88 & 576.36 & 577.00 & 576.39 & 576.03 \\
\hline
\end{tabular}


Table 6. Water levels in test intervals isolated by use of a packer assembly near Lemont, Illinois, February 15-23, 2011.

[underline denotes interval with fracture; >, greater than]

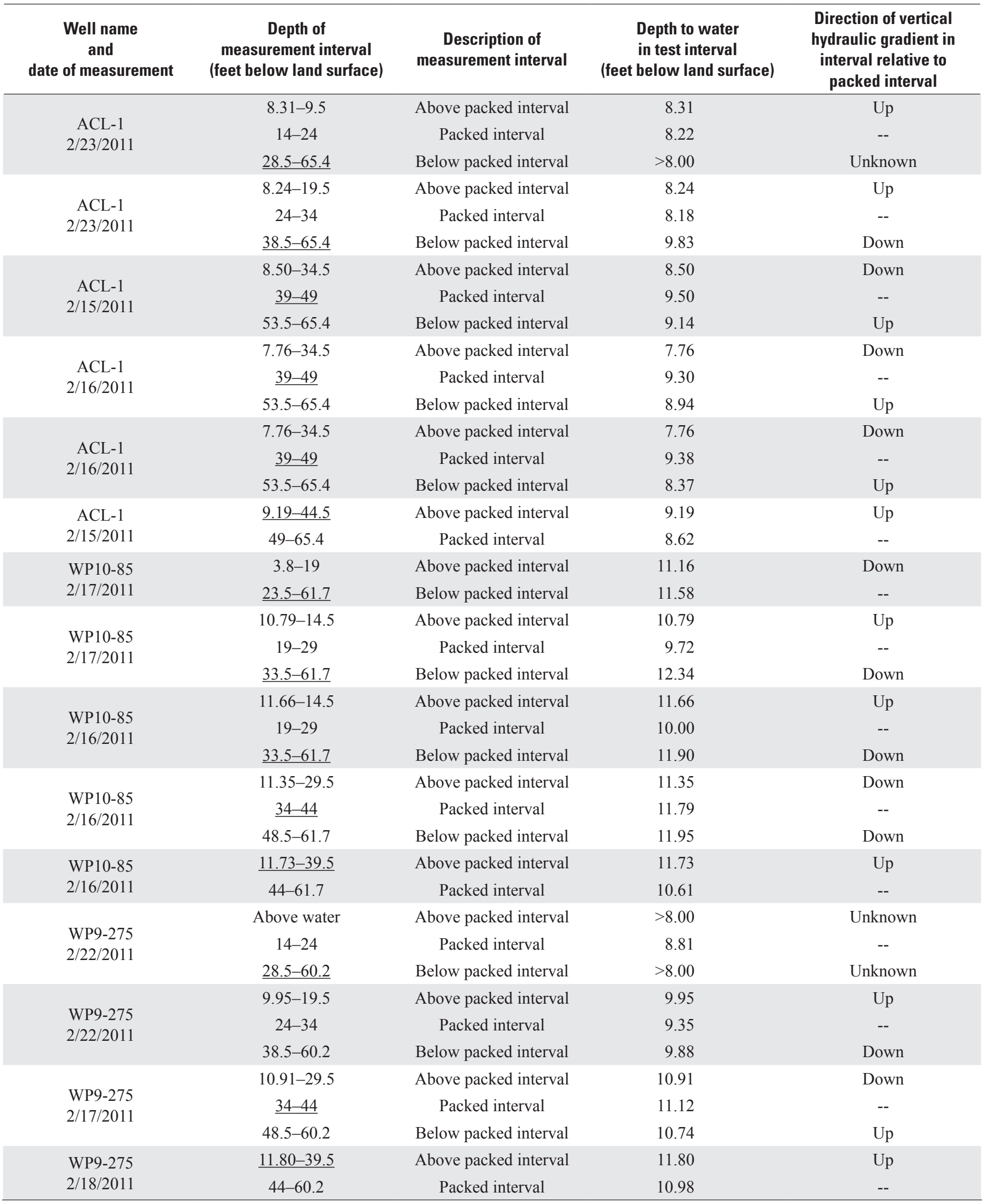



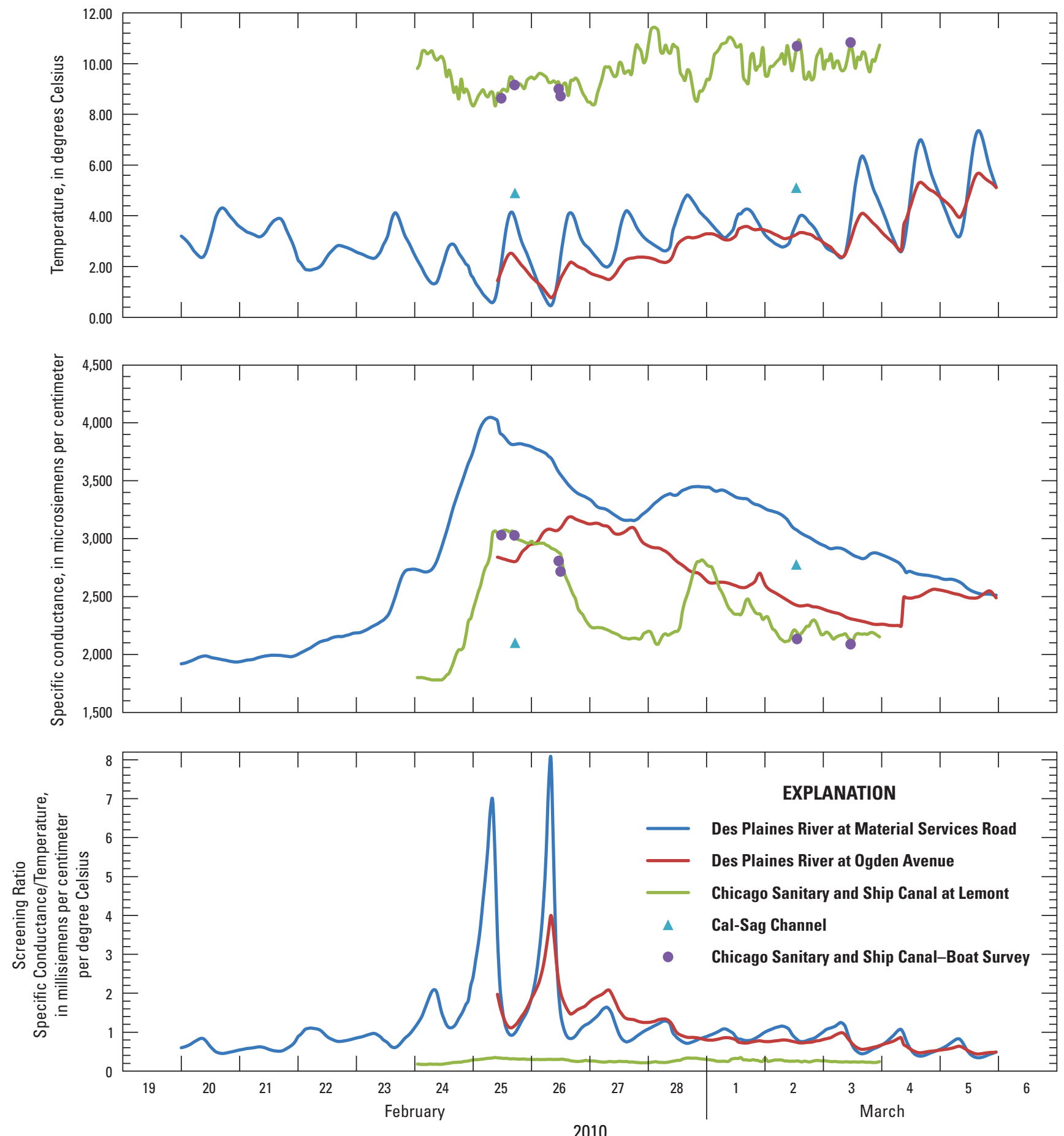

Figure 27. Temperature and specific conductance data, and ratio of specific conductance and temperature of the Des Plaines River and the Chicago Sanitary and Ship Canal near Lemont, Illinois, February 19-March 6, 2010. 
This evaluation yielded a total of 27 stationary anomalies in water quality (higher specific conductance, lower temperature, or higher screening ratio) along the north or west (DPR adjacent) wall of the CSSC (fig. 10B-H), which is the most probable pathway for interbasin spread of Asian carps. Several of these anomalies are near seeps or areas of overland or nearsubsurface flow to the CSSC from the wetlands, such as near the pipe arch (fig. 10B) and I-355 (fig. 10C). Additionally, several anomalies are at boat slips (fig. 10C, D, E) and could be present due to anthropogenic activities such as bilge discharge, local application of deicing salts, or the effects of slow mixing of water from the CSSC channel and the boat slips.

One of the locations where comparatively low temperature and high specific conductance was identified was the boat slip near well ACL-1 (fig. 10D), indicating that comparatively saline groundwater may be discharging to the CSSC in this area. This interpretation is consistent with multiple lines of geologic and hydraulic evidence discussed earlier in this report.

Groundwater quality was not assessed during the profiles, and it is possible that the anomalies could reflect groundwater inputs that are not necessarily reflective of water that has been highly influenced by the chemistry of the DPR. Therefore, the presence and causes of these anomalies is interpreted with some caution.

\section{Temperature}

Temperature trends of the CSSC and DPR were similar during continuous monitoring from May through November 2011 (fig. 28). Surface-water temperatures increased from about $15{ }^{\circ} \mathrm{C}$ in May to about $30^{\circ} \mathrm{C}$ in July, remained comparatively stable at about $25^{\circ} \mathrm{C}$ through early September, then decreased through the end of the monitoring period to about $5-12{ }^{\circ} \mathrm{C}$ in November 2011. Surface-water temperatures are affected by diel and longer term variations in atmospheric temperatures, increasing and decreasing as atmospheric temperatures change. Water temperatures also decreased in response to precipitation events. The temperature of the DPR and CSSC were similar from May through about mid-September, but the temperature of the DPR was several degrees lower by November.

Groundwater temperatures in wells ACL-1, WS4-W1, and WP10-85 showed similar values and trends during the period of monitoring (fig. 28), increasing overall from about $12{ }^{\circ} \mathrm{C}$ in early April to about $15^{\circ} \mathrm{C}$ in mid-November. Groundwater temperatures were substantially lower than temperatures of the DPR and CSSC during most of the monitoring period. Trends in groundwater temperatures appear to be independent of trends in temperature of the DPR or CSSC. For example, groundwater temperatures increased about $4{ }^{\circ} \mathrm{C}$ overall during the period of monitoring, whereas surface-water temperatures rose and fell more than $20^{\circ} \mathrm{C}$ over the same period. In addition, the large, abrupt decreases in temperature in the surface-water bodies associated with numerous precipitation events (including the events associated with near peak of investigation water levels on the DPR in late May and early June) resulted in no change to the groundwater temperatures. An abrupt increase in temperature at well ACL-1 in early May is attributed to removal of the packer assembly in the well on this date and a lowering of the temperature probe to the elevation of the fracture in the well.

\section{Specific Conductance}

The specific conductance of the CSSC and DPR ranged from about 400 microsiemens per centimeter $(\mu \mathrm{S} / \mathrm{cm})$ to about 1,200 $\mu \mathrm{S} / \mathrm{cm}$ during the monitoring period (fig. 29). Specific conductance values in the CSSC showed numerous short-term decreases of about $200-300 \mu \mathrm{S} / \mathrm{cm}$ in response to some of the precipitation events, decreased overall from about $1,000 \mu \mathrm{S} / \mathrm{cm}$ in May to about $650 \mu \mathrm{S} / \mathrm{cm}$ in early September, then increased to about $900 \mu \mathrm{S} / \mathrm{cm}$ by late November 2011 . Specific conductance values in the DPR decreased by as much as $800 \mu \mathrm{S} / \mathrm{cm}$ in response to some precipitation events but tended to return to values between about 1,000 and $1,200 \mu \mathrm{S} / \mathrm{cm}$.

The specific conductance of groundwater at wells ACL-1, WP10-85, WS4-W1, and WS4-W2 exceeded 17,500 $\mu \mathrm{S} / \mathrm{cm}$ (fig. 29). These values are substantially higher than in the DPR and the CSSC and are atypically high for near-surface groundwater in Illinois. However, the accuracy of these values is corroborated by the high concentrations of major ions (particularly sodium and chloride) detected in the groundwater sample collected at well WP10-85 (table 7) and specific conductance readings obtained from combination water level and specific conductance probes. The cause of this elevated specific conductance appears to be dissolution of road salt that may have been stored in the vicinity of well WS4-W1 several years prior to this investigation. These conditions are not representative of water quality in the Silurian dolomite aquifer in the study area as a whole.

Specific conductance showed an overall decrease during the period of monitoring at wells ACL-1 and WS4-W2. These patterns are consistent with salt dilution due to slow, diffuse recharge of lower conductivity water from the wetlands, the DPR, or (periodically) the CSSC through the aquifer matrix.

Specific conductance at well WP10-85 showed periods of increase and decrease during the monitoring period but no clear overall trend. Periods of stable, high specific conductance in well WP10-85 were followed by decreases in late April through early May and mid-June through mid-July that correspond to periods with minimal precipitation. 


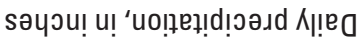

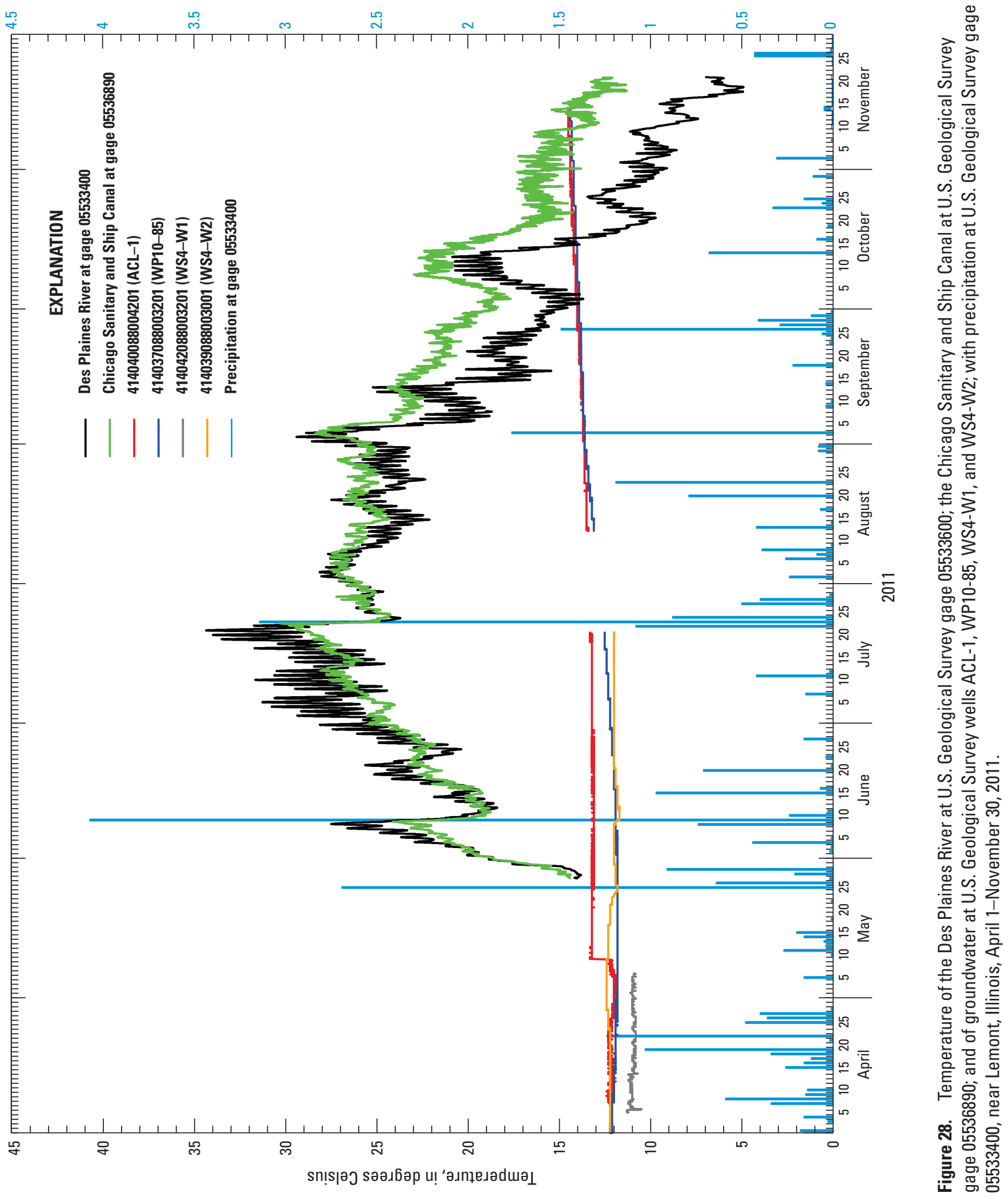




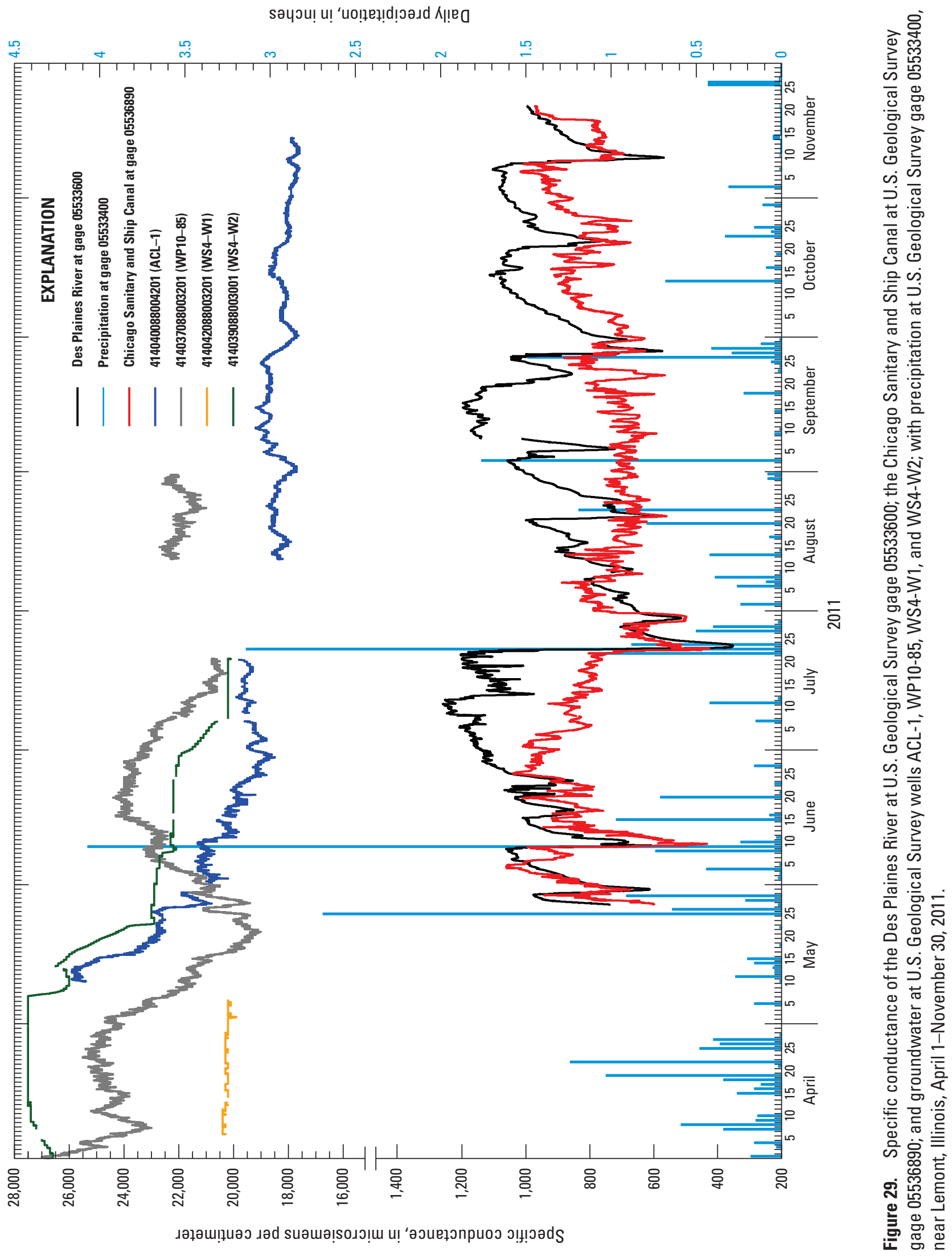


Table 7. Concentration of selected constituents in groundwater at well WP10-85 near Lemont, Illinois, December 2, 2012.

\begin{tabular}{|cc|}
\hline Constituent & $\begin{array}{c}\text { Concentration } \\
\text { (milligrams per liter) }\end{array}$ \\
\hline Calcium & 1,540 \\
\hline Magnesium & 599 \\
\hline Sodium & 4,840 \\
\hline Potassium & 360 \\
\hline Chloride & 7,850 \\
\hline Sulfate & 281 \\
\hline Fluoride & 0.69 \\
\hline Iron & 4.7 \\
\hline Manganese & 0.04 \\
\hline Silica & 60 \\
\hline Bromide & 1.3 \\
\hline
\end{tabular}

The increasing specific conductance observed in mid-May through mid-June corresponds to a period of elevated precipitation. The relation between specific conductance and precipitation at well WP10-85 would be better understood with a longer period of monitoring, but the available data are consistent with movement of the center of the salt plume toward and away from well WP10-85 in response to alterations in flow direction associated with changes in the amount of precipitation.

The abrupt decreases in specific conductance in the surface-water bodies associated with numerous precipitation events were not clearly correlated to decreases in the specific conductance of the groundwater, with the possible exception of ACL-1 during some individual precipitation events in late May, early June, and late September 2011. These decreases may reflect the effects of recharge from the CSSC.

\section{Dissolved Oxygen}

Dissolved oxygen (DO) concentrations in the DPR and CSSC showed similar trends during the monitoring period (fig. 30); however, DO in the CSSC was consistently lower than in the DPR and showed less variation. DO concentrations in the DPR typically were above 8 milligrams per liter ( $\mathrm{mg} / \mathrm{L})$, exhibited diurnal variations of up to $12 \mathrm{mg} / \mathrm{L}$, decreased several milligrams per liter in response to certain precipitation events, and increased overall from about $8 \mathrm{mg} / \mathrm{L}$ in May to about $12 \mathrm{mg} / \mathrm{L}$ in November 2011. The high DO concentrations and diurnal variations observed during much of JuneSeptember 2011 are likely due to DO production during algal photosynthesis and DO consumption during the decomposition of organic matter. DO concentrations in the CSSC showed diurnal variations of about $1 \mathrm{mg} / \mathrm{L}$, decreases of as much as about $7 \mathrm{mg} / \mathrm{L}$ following some precipitation events, and an overall increase from about $4 \mathrm{mg} / \mathrm{L}$ in May to about $7 \mathrm{mg} / \mathrm{L}$ in November.

DO concentrations in groundwater were consistently less than $0.5 \mathrm{mg} / \mathrm{L}$ at wells WS4-W1, WS4-W2, and WP10-85, and showed little variation through time (fig. 30). These data are further indication that surface-water and groundwater chemistry are substantially different in the focus area and that there is little or no rapid exchange of water between the systems.

DO concentrations in groundwater are too low to sustain Asian carps once they hatch (Duanne Chapman, U.S. Geological Survey, oral commun., 2013). It is crucial to the potential for interbasin spread by way of the groundwater pathway, therefore, that travel from the DPR to the CSSC be completed before the carps eggs hatch. Hatching typically occurs between about 15 and 65 hours after spawning at temperatures of 30 and $18{ }^{\circ} \mathrm{C}$, respectively (Murphy and Jackson, 2013).

\section{Implications of Water-Quality Data Regarding the Potential for Interbasin Spread of Asian Carps by Way of the Groundwater Pathway}

Temperature, specific conductance, and DO data collected during this investigation demonstrate that the surface water and groundwater in the focus area have distinctly different chemistry. Surface water tends to have high, highly variable temperature and DO and low specific conductance in comparison to groundwater. Groundwater tends to have low, fairly constant temperature and DO and extremely high specific conductance in comparison to surface water. The large differences in the chemistry of the surface water and groundwater in the focus area, coupled with the fact that substantial short-term changes in surface-water chemistry are not reflected (or not clearly reflected) in groundwater chemistry indicate that groundwater in the fractures within the focus area does not receive substantial, rapid recharge from the DPR or the CSSC, even during high-water events on the DPR that are coupled with low water on the CSSC. These data further indicate that Asian carps are unlikely to move from the DPR to the CSSC through secondary-permeability features in the aquifer, at least not rapidly enough to survive the journey. 


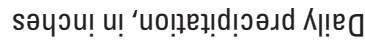

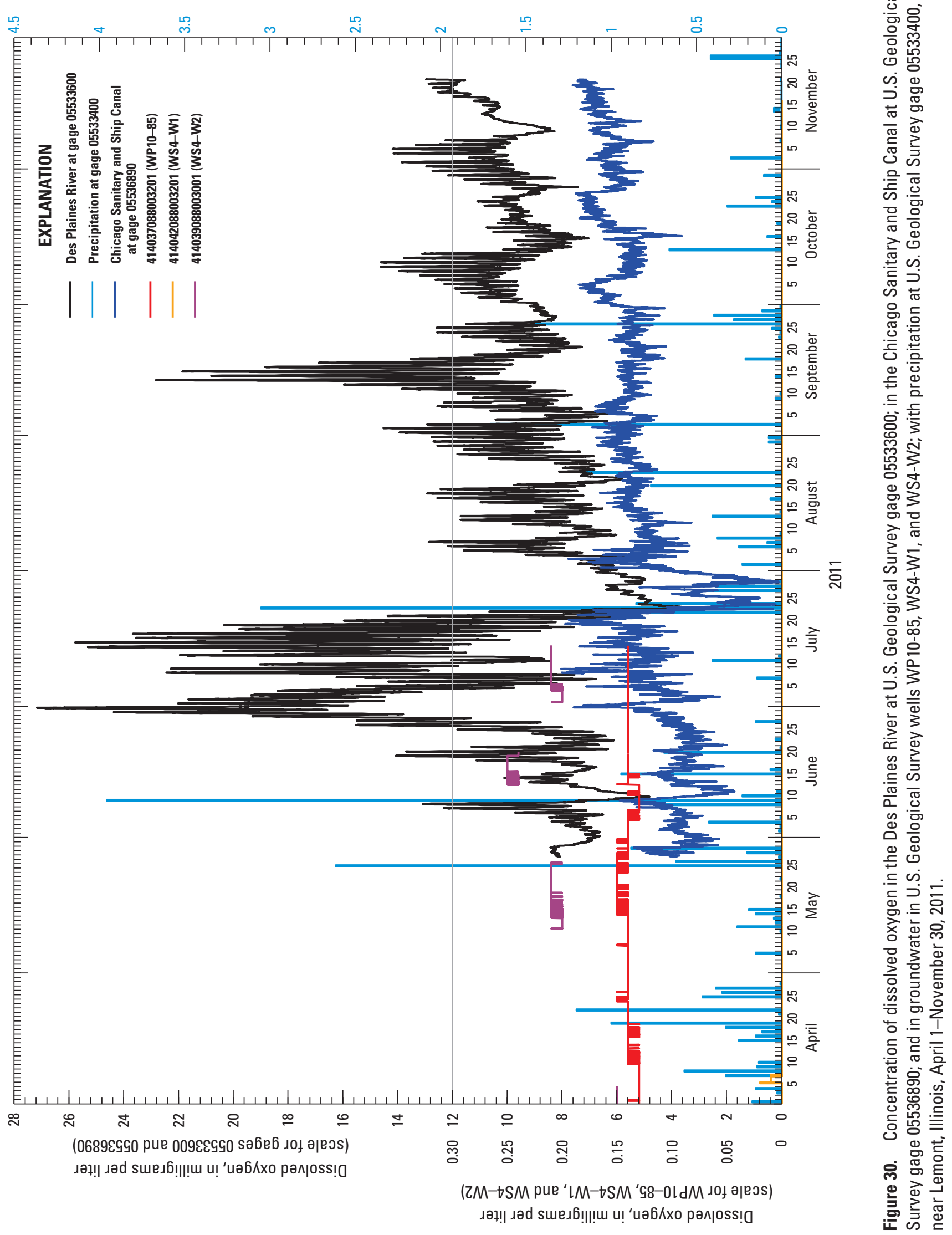




\section{Potential For Interbasin Spread Of Asian Carps By Way Of The Groundwater Pathway}

The potential for interbasin transfer of Asian carps from the IMC to the CSSC seems to be precluded by the Texaco dam, which appears to be an effective barrier to invasivespecies spread along the IMC under any likely hydrologic scenario. Should the Texaco dam be removed or compromised, the potential for invasive-species spread from the IMC to the CSSC by way of the groundwater pathway would need to be evaluated further in the area between the electric fish barrier and rock dam 1. However, the small height of the water column in most of the IMC limits the number of secondary-permeability features that could transmit flow between the IMC and the CSSC, and it is probable that paleosediment as well as recent sediment from the IMC has partly or completely filled these features if they are present. Additionally, sedimentation of the IMC itself has reduced the habitable area upstream of the electric fish barrier. However, should Asian carps manage to spread beyond rock dam 1, culverts between the IMC and CSSC could provide a travel pathway.

Interbasin spread of Asian carps from the DPR to the CSSC by way of the groundwater pathway in the area of interest requires (1) the absence of sediment on the bottom of the DPR; (2) a hydraulic gradient capable of causing the movement of water and the Asian carps from the DPR to the CSSC; (3) a continuous network of interconnected secondary-permeability features between the bed of the DPR and the walls of the CSSC through which the Asian carps can travel; (4) aperture of the secondary-permeability features sufficient to allow the free movement of the Asian carps, which in the case of Asian carps is greater than about 0.13 in.; and (5) sufficiently rapid travel time to allow the Asian carps to survive the trip, which in the case of Asian carps would be less than 2 days between spawning and hatching.

Evaluation of the sediment of the DPR, the geologic material between the DPR and the CSSC, and the geologic material intercepting the walls of the CSSC indicates no apparent potential for interbasin spread of Asian carps by way of groundwater flow in almost all of the area of interest, from about the midpoint between Kingery Highway and Lemont Road east to Stickney (with the exception of a small area near Kingery Highway where the bedrock is in contact with the DPR). This absence of potential for interbasin spread by way of groundwater results because the interconnected pore spaces in the predominately fine-grained sediments at the bottom of the DPR in this area are too small to allow the Asian carps to move beyond the river sediments, because bedrock is not in contact with the DPR in almost all of this area (and the CSSC in much of this area), and because the unconsolidated geologic deposits between the DPR and the CSSC in this area also have interconnected pore spaces that are too small to allow the Asian carps to move into the underlying fractured-rock aquifer.

From about the midpoint between Kingery Highway and Lemont Road to Romeo Road, most or all of the bed and bank of the DPR is in contact with bedrock and the waterlevel elevation in the DPR is several feet higher than it is in the CSSC, indicating the hydraulic potential for flow from the DPR to the CSSC by way of groundwater. Field geologic, sediment, DC-resistivity, and MBES surveys; fracture evaluation; and flow and water-quality profiles indicate that the focus area is the only place in the study area where a network of secondary-permeability features (in the form of vertical and horizontal fractures) potentially capable of serving as a pathway for spread of Asian carps from the DPR to the CSSC might be present.

Evaluation of lithologic, geophysical, water-level, flowprofile, and water-quality-profile data from the DPR, CSSC, and monitoring wells within the focus area demonstrates the presence of a permeable horizontal fracture that is hydraulically connected to the CSSC. The absence of this fracture in the wells located away from the CSSC indicates that this fracture does not extend to the area of the DPR. The fracture also has an observed aperture of about 0.08 in., too small to allow transport of a 0.13-0.27-in. water-hardened Asian carp egg. Continuous water-level and water-quality data indicate that although the hydraulic potential exists for water to flow from the DPR into the fractured part of the groundwater system, and from the fracture into the CSSC, this flow is not occurring in a timely fashion, even during high-water conditions on the DPR. The apparently limited hydraulic connection between the DPR and the fracture near the CSSC in the focus area appears to be due to the absence of secondary-permeability features connecting these two water bodies. Furthermore, groundwater-velocity estimates of about $10 \mathrm{ft} / \mathrm{d}$ obtained from evaluation of the borescope data indicate that even if there was good hydraulic connection between the DPR and the groundwater system, approximately 20 days would be required for Asian carps to travel the $200 \mathrm{ft}$ from the DPR to the CSSC in the boat slip by well ACL-1 under typical hydraulic conditions. In addition, water-quality data in the wells indicate that the groundwater in the focus area is a harsh environment for 
Asian carps. The groundwater temperature is in the range at which embryonic development ceases for bighead and silver carps ( 14 and $11.1^{\circ} \mathrm{C}$, respectively) (Chapman and George, 2011) during part or all of the monitoring period. The salinity of the water is above toxic levels for most juvenile Asian carps (Garcia and others, 1999; Zang and others, 1989) in parts of the focus area, and the groundwater is nearly depleted of oxygen. Therefore, multiple lines of evidence indicate little or no potential for interbasin transfer of Asian carps by way of the groundwater pathway in the focus area (or elsewhere within the area of interest) under the conditions that existed during the period of investigation. This interpretation could potentially be altered if data from potential vertical fractures in the focus area were available.

The minimal potential for interbasin spread of Asian carps by way of the groundwater pathway within the study area is further demonstrated by the results of the dye tracer study done on the DPR in November 2011. Because of technical and safety concerns, the tracer test was performed during conditions of decreasing, but approximately typical, stage and discharge (figs. 12, 13) rather than during a high-water event. Therefore, the test results indicate typical, rather than most rapid conditions for invasive-species movement and do not test near-surface flow pathways in the dolomite that could be active near the DPR when water levels are higher. However, the results of the tracer test, particularly in combination with the continuous water-quality data, are still applicable and provide additional data to indicate the low potential for interbasin spread through the groundwater.

Stage and discharge of the DPR decreased for the duration of tracer injection as the DPR recovered from the precipitation event that occurred November 7-10, 2011 (figs. 12, 13). Discharge at the injection site (fig. 5) was measured to be 912 and $840 \mathrm{ft}^{3} / \mathrm{s}$ on November 14 (at 1330) and 15 (at 0830 ), respectively. Discharge at gage 05533600 at I-355 was measured to be 994 and $873 \mathrm{ft}^{3} / \mathrm{s}$ on November 14 (at 1135) and 15 (at 1200), respectively.

Measurements of tracer concentration through time collected as part of this investigation indicate a 7.55-hour travel time from the injection point to DP-1 at Lemont Road (gage 0533500) (figs. 5, 31A), a distance of about $4.12 \mathrm{mi}$, resulting in a leading-edge velocity through that reach of $0.80 \mathrm{ft} / \mathrm{s}$ (table 8). Tracer movement from DP-1 at Lemont Road to DP-2 at I-355 (gage 05533600), a distance of $1.63 \mathrm{mi}$, took 1.75 hours, resulting in a leading-edge velocity of 1.37 feet per second (ft/s) through this reach. Tracer movement from DP-2 at I-355 to DP-3 at the Lockport Lock and Dam, a distance of $8.51 \mathrm{mi}$, took 8.67 hours, resulting in a leading-edge velocity through this reach of $1.44 \mathrm{ft} / \mathrm{s}$. These data demonstrate a consistent increase in the velocity of the DPR from upstream to downstream, which is a reflection of the increased downward slope of the DPR in these stream reaches (fig. 15).

Dye-concentration curves observed at sites along the DPR indicate that in spite of performing a 25.2-hour continuous injection, mixing and dispersion led to shorter, approximately 17.7 - to 19.6 -hour concentration "plateaus" at the downstream measurement sites on the DPR (table 8; fig. 31A). Under ideal, steady-flow conditions, these plateaus should have lasted for approximately 25 hours. The variability observed during the dye concentration plateau is likely a result of several factors. First, the general positive trend in the data toward higher concentrations at the end of the plateau period relative to the beginning of the plateau period is caused by the decrease in discharge in the DPR over the course of the injection and the maintenance of a near-constant injection rate throughout the 25.2-hour injection period. The highly variable concentration during the plateau periods at DP-1 and DP-2 (and to a lesser extent at DP-3) is likely caused by clogging of the injection nozzles at around 1200 and 1415 hours on November 15, combined with incomplete lateral mixing in the DPR. During these malfunctions, all efforts were made to ensure a constant delivery rate of dye through the remaining, unclogged nozzles. However, each time a nozzle clogged, the dye was not being delivered equally across the DPR width. In spite of being 4.12 (DP-1) and $5.75 \mathrm{mi}$ (DP-2) downstream of the injection site, the lateral mixing was not strong enough to redistribute the dye across the channel uniformly, resulting in fluctuations in the concentration at DP-1 and DP-2. Finally, the injection site was adjacent to an outfall of a small wastewater treatment plant. Any diurnal variation in discharge from the plant could have added variability to the concentration plateaus at the downstream sites. Although diurnal measurements are not available, the plant discharged 7.4, 6.9, 5.8, 5.8, and 5.8 million gallons per day (Mgal/d) on November 14, 15, 16,17 , and 18, respectively (Peter McGhee, DuPage County Wastewater Division, oral commun., 2012).

Dye tracer concentrations between 16 and 25 micrograms per liter $(\mu \mathrm{g} / \mathrm{L})$ were present in the DPR within the study area for approximately 24 hours during the test (fig. 31A). However, the dye tracer was not detected in water along the north (DPR adjacent) wall of the CSSC during sampling along 34 transects from about Kingery Highway to Romeo Road in the 72 hours following the start of tracer injection. Tracer was not detected at four monitoring points in the wetlands between the DPR and the CSSC approximately 44 hours after tracer injection began. Tracer also was not detected on the CSSC at 

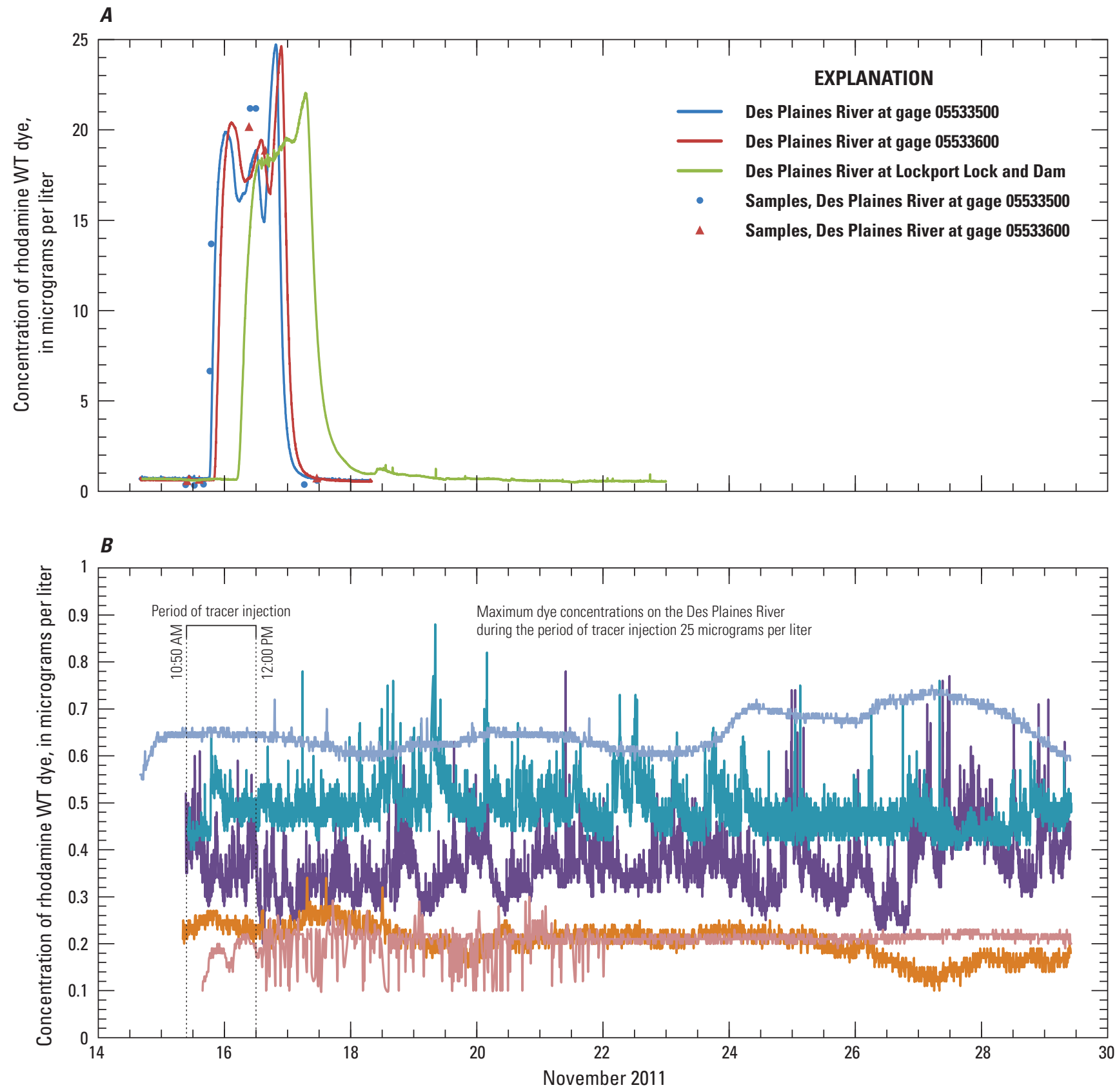

EXPLANATION

SC-1 (Chicago Sanitary and Ship Canal at gage 05568900)

SC-2 (Boat slip on Chicago Sanitary and Ship Canal near well ACL-1)

WP9-275 (well)

ACL-1 (well)

WP10-85 (well)

Figure 31. Concentration of dye tracer measured at selected locations and dates. $A$, The Des Plaines River at DP-1 (gage 05533500), DP-2 (gage 05533600), and DP-3 (Lockport lock and dam) near Lemont, Illinois, November 14-22, 2011, and B, groundwater at U.S. Geological Survey wells WP9-275, ACL-1, and WP10-85; in the Chicago Sanitary and Ship Canal at U.S. Geological Survey gage 05536890 (SC-1); and in the Chicago Sanitary and Ship Canal at the boat slip near well ACL-1 (SC-2) near Lemont, Illinois, November 14-29, 2011. Reported dye concentrations of less than 1 microgram per liter likely due to interference from turbidity. 
Table 8. Summary of dye transport observations on the Des Plaines River near Lemont, Illinois, November 14-28, 2011.

[*, background concentrations are false positives due to effect of turbidity on measuring device]

\begin{tabular}{cccccccccc}
\hline \multicolumn{7}{c}{ Injection start time: 10:50 am on 11/15/11; injection end time: 12:00 pm on 11/16/11 } \\
\hline $\begin{array}{c}\text { Station } \\
\text { name }\end{array}$ & $\begin{array}{c}\text { Location } \\
\text { (shown in figure 5) }\end{array}$ & $\begin{array}{c}\text { Distance } \\
\text { downstream } \\
\text { of injection } \\
\text { (miles) }\end{array}$ & $\begin{array}{c}\text { Time to } \\
\text { arrival of } \\
\text { leading } \\
\text { edge } \\
\text { (hours) }\end{array}$ & $\begin{array}{c}\text { Leading } \\
\text { edge } \\
\text { velocity } \\
\text { (feet per } \\
\text { second) }\end{array}$ & $\begin{array}{c}\text { Time to } \\
\text { trailing } \\
\text { edge } \\
\text { (hours) }\end{array}$ & $\begin{array}{c}\text { Peak } \\
\text { concentration } \\
\text { (micrograms } \\
\text { per liter) }\end{array}$ & $\begin{array}{c}\text { Plateau } \\
\text { duration } \\
\text { (hours) }\end{array}$ & $\begin{array}{c}\text { Background* } \\
\text { concentration } \\
\text { (micrograms } \\
\text { per liter) }\end{array}$ \\
\hline DP-1 & $\begin{array}{c}\text { Des Plaines River at } \\
\text { Lemont Road }\end{array}$ & 4.12 & 7.55 & 0.80 & 46.80 & 24.76 & 19.5 & 0.71 \\
\hline DP-2 & $\begin{array}{c}\text { Des Plaines River at I-355 } \\
\text { Des Plaines River near } \\
\text { Lockport Lock and Dam }\end{array}$ & 5.75 & 9.30 & 1.37 & 49.30 & 24.15 & 19.6 & 0.64 \\
\hline DP-3 & 14.26 & 17.97 & 1.44 & 96.47 & 22.08 & 17.7 & 0.66 \\
\hline
\end{tabular}

monitoring points SC-1 or SC-2 (fig. 31B) or in groundwater at wells ACL-1, WP10-85, or WP9-275 during continuous monitoring for 14 days after tracer injection on the DPR began (fig. 31B). Note that although the fluorometers are capable of detecting dye at concentrations of $0.01 \mu \mathrm{g} / \mathrm{L}$, the sub-microgram-per-liter "background" concentrations of dye reported as being detected by the fluorometers (table 8 ) are actually false values caused by the presence of turbidity in the water. This interpretation was verified by the high degree of correlation observed when turbidity values were compared with contemporaneous fluorometer readings at several sites (fig. 32) and the fact that low concentrations of dye were reported at several locations prior to the start of tracer injection or the possible arrival of tracer at the fluorometer (fig. 31). The tracer data indicate that water movement from the DPR to the CSSC by way of fractures and other secondary-permeability features in the groundwater system requires more than 14 days to be completed under approximately typical hydraulic conditionsa travel time that Asian carp eggs would not survive in the aquifer. Shorter travel times would be expected if movements were to occur during an extreme hydraulic event, but waterlevel and water-quality data collected during this investigation do not indicate rapid movement of water from the DPR into and through the groundwater system to the CSSC even during high-water events on the DPR.

Although it cannot be conclusively proven that unidentified groundwater pathways capable of allowing the interbasin spread of Asian carps are not present, the insights into the geology, hydrology, and water quality obtained from this investigation indicate that the data-collection efforts during this investigation, and especially during the later stages of the investigation, were targeting the optimal location - the focus area. If Asian carps were capable of spreading from the DPR to the CSSC by way of a groundwater pathway, that pathway is most likely to have been located within the focus area where the following conditions were present.

- The Silurian dolomite aquifer is in direct contact with both the DPR and CSSC.

- The Silurian dolomite aquifer is present and spatially continuous throughout the area between the DPR and the CSSC. Its continuity is not interrupted by erosion or the presence of unconsolidated materials.

- The Silurian aquifer contains a network of vertical and horizontal fractures.

- Permeable fractures in physical proximity to the CSSC are present in at least part of this area.

- Permeable fractures move sufficient water to induce measureable flow and changes in water quality in the CSSC.

- The DPR and the CSSC are as close to each other (near well ACL-1) as at any point in the area of interest.

The fact that interbasin spread of Asian carps by way of the groundwater pathway is not viable within the focus area is a compelling indication that it is not viable anywhere within the area of interest. 


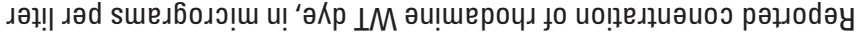

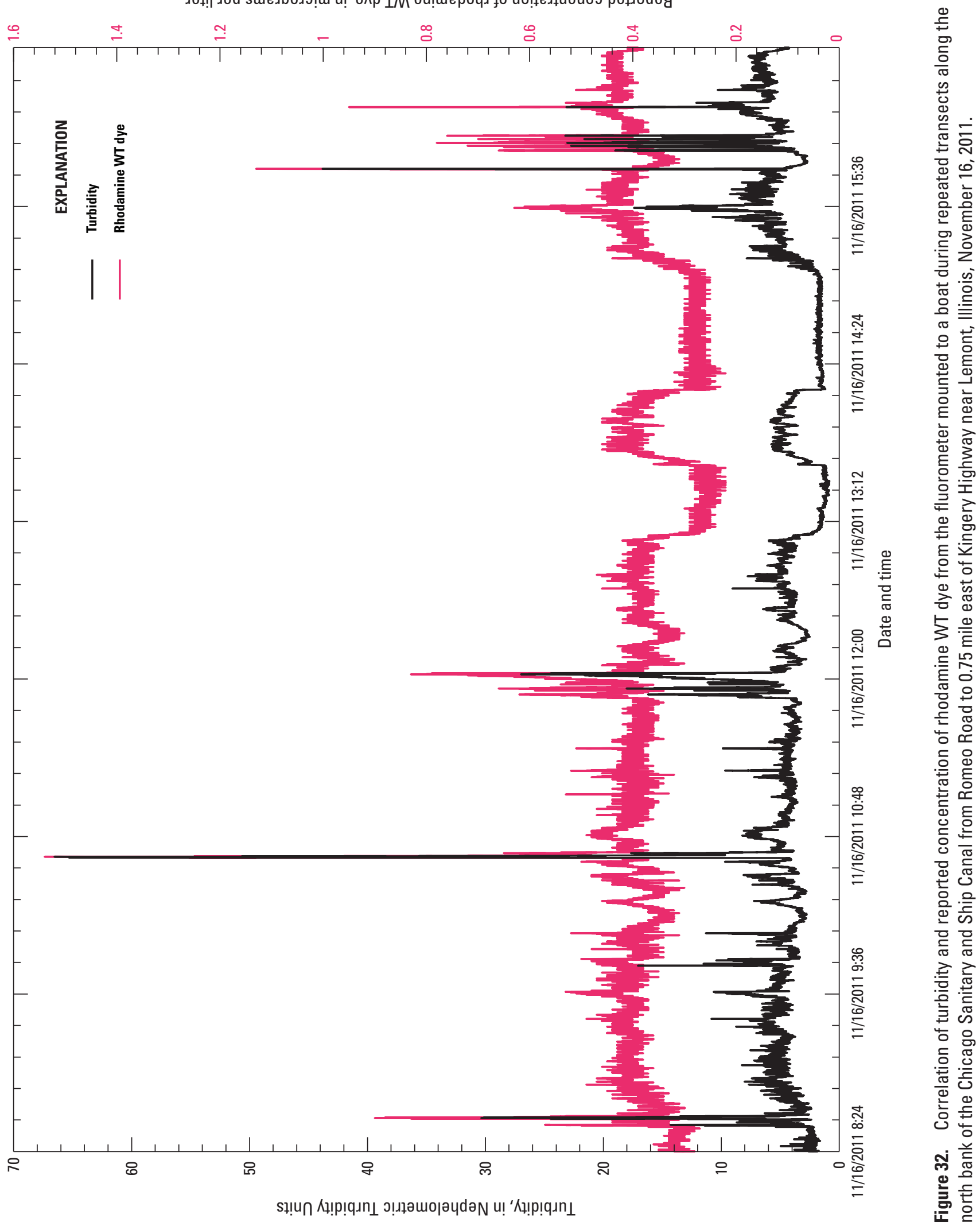




\section{Summary and Conclusions}

Bighead and silver carps are Asian carps that have traveled up the Mississippi River Basin to within approximately $30 \mathrm{mi}$ of Lake Michigan. These carps have the potential to cause substantial ecological and economic damage if they become established in the Great Lakes, so an electric fish barrier was erected across the Chicago Sanitary and Ship Canal (CSSC) to prevent them from spreading up the canal and into Lake Michigan. However, the Asian carps will have unimpeded access to the Des Plaines River north (upstream) of the electric fish barrier, an area where the Des Plaines River and the CSSC are separated by as little as $200 \mathrm{ft}$ of fractured dolomite. There are concerns that Asian carp eggs may be able to travel through saturated secondary-permeability features in the dolomite, circumventing the electric fish barrier. An investigation was done by the U.S. Geological Survey to assess the potential for interbasin spread of Asian carps, and other invasive species that may occupy this area in the future, by way of the groundwater pathway.

The spread of Asian carps to that part of the Illinois and Michigan Canal within the study area is unlikely because the Texaco dam and rock dam 1 serve as barriers to movement. If Asian carps do spread to the area of rock dam 1 in the Illinois and Michigan Canal, the potential for them to spread to the CSSC by way of the groundwater pathway is considered small because infilling of secondary-permeability features by sediment in the Illinois and Michigan Canal and Pennsylvanianaged sediments in the dolomite itself likely have blocked any potential connection with the CSSC.

During this investigation, the stage of the Des Plaines River typically trended toward a base level of about $584 \mathrm{ft}$ North American Vertical Datum of 1988 (NAVD 88) but increased by as much as about $6 \mathrm{ft}$ in response to snowmelt and precipitation events. The stage of the CSSC within the study area typically is maintained at about $576.7 \mathrm{ft}$ NAVD 88, but it typically was about $7 \mathrm{ft}$ lower than the stage of the Des Plaines River and could be as much as $16 \mathrm{ft}$ lower.

Surveys indicate that the bed material in the Des Plaines River primarily consists of coarse-grained aggregate and possibly dolomite in the vicinity of Kingery Highway. East of Kingery Highway, the bed sediment increasingly consists of fine-grained alluvium. From about 0.6 mi east of Lemont Road through the end of the study area at Romeo Road, the bed and bank of the Des Plaines River are in direct contact with exposed bedrock. Areas where the river is in contact with exposed bedrock are the most likely places for Asian carps to enter the groundwater system and were where most of the investigative effort was focused.

Vertical fractures were identified within the dolomite throughout the area of interest. However, most of the fractures had no measureable aperture or were filled with sediments. During field geologic surveys, open fractures were not observed to extend substantially beyond the walls of the Illinois and Michigan Canal or the CSSC.
A potentially extensive network of large horizontal fractures also was identified in the deposits of the Racine Formation. However, these fractures were determined to be unlikely pathways for invasive-species spread because the bedrock deposits containing these fractures were removed by erosion along the Des Plaines River, and the riverbed and riverbanks were in contact with unconsolidated deposits.

Several investigative techniques identified a hydraulically active, laterally extensive, horizontal fracture near the CSSC in the focus area west of Lemont Road at an elevation of about 546-552 ft NAVD 88. Wells drilled further away from the canal in this area to elevations of 517 and $524 \mathrm{ft}$ did not intercept any fractures. The fracture identified near the canal at an elevation of 546-522 ft has horizontal hydraulic conductivity values between about 150 and $620 \mathrm{ft} / \mathrm{d}$ and an estimated groundwater velocity of about $10 \mathrm{ft} / \mathrm{d}$ in a direction oriented about 217 degrees from magnetic north. It is unclear whether this fracture is a natural feature or results from excavation of the CSSC.

Water-level data collected in and near the focus area indicates the potential for water from the Des Plaines River and overlying wetlands to recharge the low-permeability matrix of the Silurian aquifer. Water then has the potential to flow from the aquifer matrix to the permeable horizontal fracture, and then from the fracture to the CSSC. Water-level data indicate that the fracture within the focus area is hydraulically well connected to the CSSC but not to the Des Plaines River or the wetlands.

The values and trends in temperature, specific conductance, and concentration of dissolved oxygen in the CSSC and Des Plaines River were similar during the period of monitoring but are substantially different from the values and trends in the temperature, specific conductance, and concentration of dissolved oxygen in groundwater in and near the focus area. These data indicate that the trends in groundwater quality, particularly in those parts of the aquifer where permeable fractures are present, cannot be attributed to rapid recharge from Des Plaines River or the CSSC to the groundwater system. This interpretation is supported by fact that dye tracer placed in the Des Plaines River was not detected in the groundwater wells located near the canal during 14 days of monitoring, an indication that water from the Des Plaines River requires more than 14 days to flow through the groundwater system under approximately typical hydraulic conditions.

Fracture data collected by previous investigators, direct-current resistivity surveys, field geologic and sediment surveys, stage data from the Des Plaines River and the CSSC, and flow and water-quality profiling on the canal indicated the potential for hydraulic interconnection between the Des Plaines River to the CSSC through the groundwater pathway and the potential viability of this pathway for interbasin spread of Asian carps. However, detailed geologic, hydraulic, and water-quality data (including tracer concentrations) obtained from monitoring wells, in combination with detailed hydraulic and water-quality data from the river and canal, indicate that interbasin spread of Asian carps from the Des Plaines River 
to the CSSC by way of transport through groundwater is unlikely. An interconnected network of secondary-permeability features large enough to transport Asian carp eggs does not appear to be present in the study area. Groundwater velocities, and groundwater quality in at least some parts of the study area, also are not conducive to the eggs being able to survive the journey.

\section{References Cited}

Asian Carp Regional Coordinating Committee, 2012, Asian carp monitoring and rapid response plan: Asian Carp Regional Coordinating Committee, interim summary reports [variously paginated].

Chapman, D.C., and George, A.E., 2011, Developmental rate and behavior of early life stages of bighead and silver carp: U.S. Geological Survey Scientific Investigations Report 2011-5076, $11 \mathrm{p}$.

Demissie, Misganaw, and Akanbi, A.A., 1994, Hydrologic and hydraulic analyses of the Illinois and Michigan Canal at Lockport, Illinois: Illinois State Water Survey Contract Report 576, $97 \mathrm{p}$.

Demissie, Misganaw, and Xia, Renjie, 1990, Feasibility of rehabilitation of the Illinois and Michigan Canal at Lockport, Illinois: Illinois State Water Survey Contract Report 492, 106 p.

Environmental Resources Management, 1990, Remedial investigation and feasibility study, Lenz Oil Superfund Site: Prepared for the U.S. Environmental Protection Agency, Chicago, Ill. [variously paginated].

Environmental Resources Management-North Central, Inc., 1992a, Remedial investigation report, Lenz Oil Service, Inc. site, Lemont, Ill.: U.S. Environmental Protection Agency, Project no. 0252 [variously paginated].

Environmental Resources Management-North Central, Inc., 1992b, Technical memorandum no. 3A, remedial investigation, phase 1, task 2, Lenz Oil Services, Inc. site, Lemont, Ill.: U.S. Environmental Protection Agency, Project no. 0252 [variously paginated].

Garcia, L.M.B, Garcia, C.M.H., Pineda, A.F.S., Gammad, E.A., Canta, J., Simon, S.P.D., Hilomen-Garcia, G.V., Gonzal, A.C., and Santiago, C.B., 1999, Survival and growth of bighead carp fry exposed to low salinities: Aquaculture International, v. 7, p. 241-250.

George, A.E., and Chapman, D.C., 2013, Aspects of embryonic and larval development in Bighead Carp Hypophthalmichthys nobilis and Silver Carp Hypophthalmichthys molitrix: PLoS ONE v. 8. no. 8, e73829.
Hill, C.S., 1896, The Chicago main drainage channel: New York, Engineering News Publishing Co., 129 p.

Hill, Libby, 2000, The Chicago River: Chicago, Lake Claremont Press, 302 p.

Jackson, P.R., Johnson, K.K., and Duncker, J.J., 2012, Comparison of index velocity measurements made with a horizontal acoustic Doppler current profiler and a three-path acoustic velocity meter for computation of discharge in the Chicago Sanitary and Ship Canal near Lemont, Illinois: U.S. Geological Survey Scientific Investigations Report 2011-5205, 42 p.

KPRG and Associates, Inc., 2004, Site investigation and interim remedial objectives report, IMTT, Lemont, Illinois: Prepared for the Illinois Environmental Protection Agency, Springfield, Ill., [variously paginated].

Kolar, C.S., Chapman, D.C., Courtenay, W.R., Jr., Housel, C.H., Williams, J.D., and Jennings, D.P., 2007, Bigheaded carps-A biological synopsis and environmental risk assessment: American Fisheries Society Special Publication 33, $204 \mathrm{p}$.

Murphy, E.A., and Jackson, P.R., 2013, Hydraulic and waterquality data collection for the investigation of Great Lakes tributaries for Asian carp spawning and egg-transport suitability: U.S. Geological Survey Scientific Investigations Report 2013-5106, 30 p.

Nicholas J.R., and Healy, R.W., 1988, Tritium migration from a low-level radioactive-waste disposal site near Chicago, Illinois: U.S. Geological Survey Water-Supply Paper 2333, $46 \mathrm{p}$.

Nico, L.G., 2010, Mylopharyngodon piceus: Gainesville, Fla., U.S. Geological Survey nonindigenous aquatic species database, revision date July 9, 2010, accessed February 28, 2012, at http://nas.er.usgs.gov/queries/FactSheet. aspx? speciesID $=573$.

Nico, L.G., Fuller, P.L., and Schofield, P. J., 2012, Ctenopharyngodon idella: Gainesville, Fla., U.S. Geological Survey nonindigenous aquatic species database, revision date January 19, 2012, accessed February 28, 2012, at http://nas.er.usgs.gov/queries/FactSheet. aspx? speciesID $=514$.

Patel, A.G., Glassner-Shwayder, K., and Eder, T., 2010, Halting the invasion-Maintaining health of the Great Lakes and Mississippi River basin by preventing further exchange of aquatic Asian carps: Environmental Practice, v. 12 , p. $342-356$.

Shapiro, A.M., and Nicholas, J.R., 1989, Assessing the validity of the channel model of fracture aperture under field conditions: Water Resources Research, v. 25, no. 5, p. 817-828. 
Solzman, D.M., 2006, The Chicago River (2d ed.): University of Chicago Press, 289 p.

STS Consultants, Ltd., 2002, Chicagoland underflow plan, McCook Reservoir, Illinois 50\% review design documentation report-Number 2, groundwater protection system: U.S. Army Corps of Engineers, Chicago District, STS Project 1-27354-ZH [variously paginated].

U.S. Army Corps of Engineers, 1978, Des Plaines River barrier subsurface drilling and sampling information: Chicago District Civil Design Section, 26 p.

U.S. Army Corps of Engineers, 2010, Subsurface investigation, dispersal barrier efficacy study-Overflow bypass: Chicago District [variously paginated].
V3 Companies, Ltd., 2008, Subsurface bedrock investigation Centennial Trail Prairie Marsh and Lockport Powerhouse Marsh, Calumet Service Area, Will County, Illinois: Unpublished report to Metropolitan Water Reclamation District of Greater Chicago [variously paginated].

Willman, H.B., 1971, Summary of the geology of the Chicago area: Illinois State Geological Survey Circular 460, 77 p.

Zang, Weiling, Wu Wang, Ling Ye, Zheng Yu, Guofan Ni, and Bin Zhao, 1989, Toxic effects of salinity (S ppt) on some freshwater fishes: Oceanologia et Limnologia Sinica, v. 20, no. 5, p. 445-452. [In Chinese with English summary] 
Appendixes 1-4 


\section{Appendix 1. Asian Carps in the United States}

\author{
By Terrance D. Hubert, Kim T. Fredricks, and \\ Mark P. Gaikowski, U.S. Geological Survey Upper \\ Midwest Environmental Sciences Center
}

Given the highly fractured nature of the bedrock in the area around the Chicago Sanitary and Shipping Canal (CSSC) and the proximity of the Des Plaines River to this canal, the possibility that those fractures are a route for Asian carps to move from the Des Plaines River into the canal and eventually enter Lake Michigan is a legitimate concern. The main objective of this literature review was to find information on the movement of carp eggs, larvae, or fry through rock fractures. In brief, information on movement of this nature was not found after an extensive literature search. The comprehensive overview of bighead and silver carps prepared by Kolar and others (2007) will be summarized in part here with pertinent new information included.

Asian carp invasion into the Great Lakes would have negative economic consequences to the region around waterways they invade by adversely affecting the commercial fishery. The larger commercial fish sought by fishermen become scarcer as their food supply is depleted. For example, in the waters of the State of Michigan, alewife is an important food source for Chinook salmon, which is an economically important sport and commercial fish. Alewife depend on plankton as a primary food source. If Asian carps become established in the Great Lakes and reduce the plankton population, alewife populations, as well as Chinook salmon populations, will likely decline (Clapp and others, 2010).

\section{General Overview of Asian Carps in the United States}

Asian carps, members of the family Cyprinidae, became established in the southern Mississippi River in the 1970s and 1980s and are currently expanding their range north toward the Great Lakes. There are four species of Asian carp in the United States: grass carp (Ctenopharyngodon idella), black carp (Mylopharyngodon piceus), silver carp (Hypophthalmichthus molitrix), and bighead carp (Hypophthalmichthys nobilis). This paper, however, will focus solely on bighead and silver carps.

Asian carps were introduced into the United States from Asia in 1973 to provide biological control of plankton blooms in the aquaculture industry and in wastewater retention ponds (Oregon Sea Grant, 2010). Both bighead and silver carp are now found in most of the Mississippi River system (Lohmeyer and Garvey, 2008).

The range of Asian carps in the United States has been expanding. In 2002, Asian carps were in the Illinois River within 60 miles (mi) (97 kilometers) (km) of Lake Michigan, and in 2009 a dead bighead carp was found within $43 \mathrm{mi}$
(69 km) of Lake Michigan (Patel and others, 2010). Asian carps are a significant threat to the Great Lakes (Cudmore and others, 2012). The water temperatures and the overall climate in the Great Lakes are similar to that of their native range in Asia and, given access to some Great Lakes tributaries, spawning and recruitment may occur (Kolar and others, 2007; Hansen; 2010). Asian carps have the potential to disrupt the ecosystem of the Great Lakes should they become established there. One primary concern is that Asian carps may become the dominant species in the tributaries of the Great Lakes and outcompete native species that are important sources of revenue for sport and commercial fishing industries worth approximately $\$ 7$ billion annually, according to the Great Lakes Fishery Commission (American Sportfishing Association, 2008).

\section{Biology and Life History}

\section{A. General Overview of Asian Carp Biology and Life History}

Asian carps can grow to a large size, and they are able to tolerate a wide temperature range and low oxygen levels. Asian carps are highly fecund, though their fecundity varies with age, body size, and condition (table 1-1; Conover and others, 2007; Clapp and others, 2010; Oregon Sea Grant, 2010). Asian carps feed mostly on plankton or invertebrates. The diet of Asian carps is varied, suggesting that they can easily adapt to environmental changes (Sampson and others, 2009).

Growth of Asian carps seems to depend more on the quality of the food than simply the quantity of the food. Silver and bighead carps stocked in lakes in Nepal that contained more quality phytoplankton and zooplankton grew larger than carp stocked in other lakes, according to a study by Rai (2000). In that study, larvae of bighead carp were longer and heavier after 3 weeks of eating Brachionus rubens.

\section{B. Bighead Carp}

\section{B1. General Description}

Bighead carp are gray on their dorsal surface and white on their ventral surface. They have a smooth keel and small cycloid scales, and gray/black spots cover their body (Jennings, 1988). Bighead carp have a disproportionately large head and mouth with a protruding lower jaw. Their eyes are placed ventrally so that they "look down" (Stone and others, 2000; Jennings, 1988). The mouth of bighead carp is large and toothless (Clapp and others, 2010). The digestive tract, which is 3 to 5 times the body length, consists of an esophagus, intestinal swelling, intestine, and rectum (Jennings, 1988).

Bighead carp can reach a size of 40 kilograms $(\mathrm{kg})$ (about 88 pounds) (lbs) and survive in a wide range of temperatures (Kolar and others, 2007). In studies on the Missouri River in 
Table 1-1. General characteristics of bighead and silver carps present in waters of the United States (Oregon Sea Grant, 2010).

[m, meters; kg, kilograms; ${ }^{\circ} \mathrm{C}$, degrees Celsius; mg/l, milligrams per liter; >, greater than; <, less than; $\leq$, less than or equal to]

\begin{tabular}{cccccccc}
\hline Species & $\begin{array}{c}\text { Total } \\
\text { length } \\
(\mathbf{m})\end{array}$ & $\begin{array}{c}\text { Weight } \\
(\mathbf{k g})\end{array}$ & $\begin{array}{c}\text { Sexual } \\
\text { maturity } \\
\text { (years) }\end{array}$ & $\begin{array}{c}\text { Fecundity } \\
\text { (eggs/female) })^{2}\end{array}$ & $\begin{array}{c}\text { Temperature } \\
\left.\text { tolerance } \mathbf{(}^{\circ} \mathbf{C}\right) \\
\text { [preferred] }\end{array}$ & $\begin{array}{c}\text { Oxygen } \\
\text { tolerance } \\
\text { (mg/L) }\end{array}$ & Diet \\
\hline Bighead & $>1$ & $\leq 40$ & 2 to 7 & $<800,000$ & $5-38[25]$ & 0.5 & Plankton \\
Silver & $\leq 1.9$ & $\leq 35$ & 3 to 4 & $<350,000$ & $0-40$ & 0.5 & Plankton \\
\hline
\end{tabular}

${ }^{1}$ Males typically reach sexual maturity 1 year before females.

${ }^{2}$ The values reported are the potential egg production for females. However, in the United States, these values are likely lower. Additionally, fecundity increases with age and weight.

2004 and 2005, the fish were not active at water temperatures less than 2 degrees Celsius $\left({ }^{\circ} \mathrm{C}\right)$ but were active at water temperatures above $4{ }^{\circ} \mathrm{C}$ (Kolar and others, 2007). In experiments conducted in Texas, young bighead carp that were acclimated to $23{ }^{\circ} \mathrm{C}$ water selected habitats with a mean temperature of $25.4^{\circ} \mathrm{C}$ and appeared to have a maximal thermal tolerance of $38.8^{\circ} \mathrm{C}$ (Kolar and others, 2007).

There is no specific information on the longevity of bighead carp in the United States (Jennings, 1988). However, two bighead carp taken from Lake Erie, Ontario, were reported to be between 8 to 10 years old and appeared to be in excellent health and growing at the time of capture (Morrison and others, 2004). Many bighead older than 10 years and a few older than 20 years have also been found (Duane Chapman, U.S. Geological Survey, oral commun., 2012).

\section{B2. Introduction into the United States and Current Range}

Bighead carp have been introduced worldwide as a food fish and were ranked fourth in worldwide aquaculture production (Stone and others, 2000), being actively cultured in at least 32 countries (Jennings, 1988). Bighead carp were imported into the United States from China in 1973 by a private fish farmer to be used in polyculture with channel catfish (Stone and others, 2000; Jennings, 1988) and also in 1974 by fishery biologists from Auburn University for research purposes (Jennings, 1988). Bighead carp were also stocked in several U.S. water bodies in an investigation of their use to remove excessive nutrients and algae from wastewater treatment facilities (Kelly and others, 2011). By the early 1980s, they were found in waters of the Ohio and Mississippi rivers, likely as a result of escapes from aquaculture facilities (Jennings, 1988). Bighead carp became established in the Mississippi River in the early 1980s and invaded the Illinois River system in the late 1990s (DeGrandchamp and others, 2008). They are now found in waters of 23 states (fig. 1-1) with established populations in the Mississippi, Ohio, Missouri, and Tennessee Rivers (Conover and others, 2007; USGS Nonindigenous Aquatic Species database, as viewed at http://nas.er.usgs.gov/, November 8, 2012). Currently the concern is that bighead and silver carps may be in the Chicago Area Waterway System (CAWS), which includes the Calumet River systems (see maps at the end of this Appendix 1 for location of CAWS) and is a major tributary of Lake Michigan. Should bighead carp enter Lake Michigan, they may outcompete native fishes and be nearly impossible to control (Clapp and others, 2010; Cudmore and others, 2012).

\section{B3. Feeding Habits}

Adult bighead carp are filter feeders, having gill rakers that are long and close together (Jennings, 1988). Their natural food source is zooplankton and larger phytoplankton (Ke and others, 2007). However, they may feed on detritus, aquatic insects, and blue-green algae if their normal diet is scarce (Stone and others, 2000; Conover and others, 2007). Because they lack a true stomach, they feed often and may consume up to 20 percent of their body weight per day (Clapp and others, 2010). More typically, bighead carp have been found to feed daily on amounts that match 7 to 14 percent of their body mass (Opuszynski and Shireman, 1993; Cooke and others, 2009). Copepods, despite their large size, were not as frequently selected, probably because of their ability to escape predation (Opuszynski and Shireman, 1993; Dong and Li, 1994). In general, algae consumption increased with the density of the algal population when algae were the only food available (Opuszynski and Shireman, 1993). Additionally, when gut contents were examined, they showed similar proportions of phytoplankton and zooplankton as that found in the water (Cremer and Smitherman, 1980), suggesting that bighead carp do not select one over another when both phytoplankton and zooplankton were available.

$\mathrm{Gu}$ and others (1996) used isotope analysis to determine the diet of bighead carp fingerlings and compare it to that of silver carp fingerlings. Their analysis suggests that the bighead and silver carp have over 50 percent overlap in their diets and that silver carp fingerlings may rely more on zooplankton than was previously thought. Competition between the bighead and silver carps has been studied as well. Ke and others (2008) found that bighead carp preferentially consume zooplankton, 


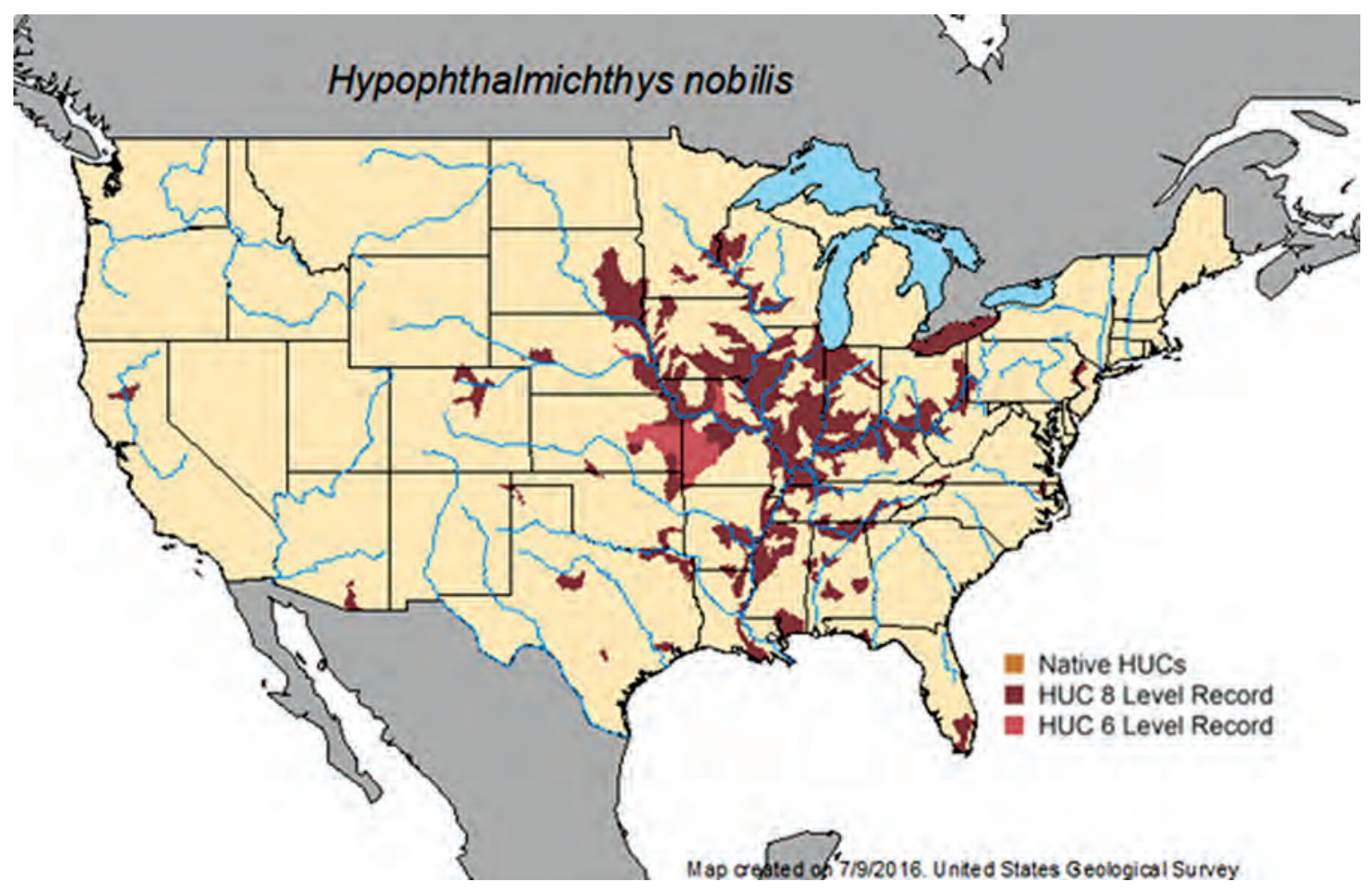

Figure 1-1. Current distribution of bighead carp in the United States (Source, U.S. Geological Survey Nonindigenous Aquatic Species database, http://nas.er.usgs.gov/queries/SpeciesMap.aspx?SpeciesID=551). (HUC, hydrologic unit code)

whereas the silver carp diet has a larger breadth of phytoplankton and zooplankton. When the two fish species are stocked together in low densities, they will both consume zooplankton; however, at high densities, their diets will shift to the niche that will allow the most efficient feeding, with bighead carp consuming zooplankton and silver carp consuming phytoplankton.

Bighead carp can grow rapidly under optimal conditions and can gain about a pound a month (Stone and others, 2000). Bighead (and silver) carp actively select their feeding area depending on plankton density or the presence of their preferred plankton species. They have many taste buds on the epithelia of their filtering organs and may use these to help select a feeding area (Dong and Li, 1994). Growth of bighead carp seems to be limited by food density as well as food quality. Growth decreased by 2.8 percent in a lake with low plankton density but increased by 2.3 percent in a lake with higher plankton density (Cooke and others, 2009). When plankton density was controlled but quality varied, carp were found to grow better in ponds that had larger amounts of digestible plankton compared to ponds that had large amounts of nondigestible plankton (Rai, 2000).

\section{Silver Carp}

\section{C1. General Description}

Silver carp are fish that have a subcarangid body. The head and dorsal surface are gray, whereas the sides of the fish are silver and the ventral surface is white. The ventral surface of silver carp is sharply keeled from the anal fin to the throat. The head of the silver carp is approximately one-third the length of its body (Conover and others, 2007). Its toothless lower jaw has a small tubercle, whereas the upper jaw is slightly notched. The intestine is long and convoluted with many loops, which is typical for fish that consume phytoplankton (Cremer and Smitherman, 1980; Kolar and others, 2007). In contrast to those of bighead carp, the gill rakers of silver carp are covered by a netlike matrix that allows the silver carp to more efficiently collect small phytoplankton from the water (Dong and Li, 1994). Their lifespan appears to be shorter out of their natural habitat, being about 5 years in the middle Mississippi River compared to 8 years in their native ranges (Williamson and Garvey, 2005). However, many silver carp in the Mississippi River have been aged at over 20 years old (Duane Chapman, U.S. Geological Survey, oral commun., 2012). 


\section{C2. Introduction into the United States and Current Range}

Silver carp were first introduced into the United States in 1973 by a commercial fish farmer, and by the mid-1970s they were used in municipal sewage treatment ponds, commercial fish production ponds, and swine lagoons in Arkansas and Illinois as biological controls to improve water quality (Conover and others, 2007; Clapp and others, 2010). They likely escaped from these ponds in the early 1980s and have now become established in waters of 16 states, including the watersheds of the Mississippi, Missouri, and Ohio Rivers (fig. 1-2).

Silver carp can tolerate a wide temperature range, with an optimal temperature range reported to be 26 to $30^{\circ} \mathrm{C}$. The upper lethal limit for young silver carp (3 to 28 days old) was found to be about $45^{\circ} \mathrm{C}$. Silver carp are able to tolerate low water temperatures well, as evidenced by survival in ponds that are near $0{ }^{\circ} \mathrm{C}$ in Alberta, Canada (Kolar and others, 2007).

\section{C3. Feeding Habits}

Young silver carp, up to 15 millimeter $(\mathrm{mm})$ total length, are obligate filter feeders. The food consumed by fry and fingerlings is strongly dependent on food availability ( $\mathrm{Lu}$ and others, 2002). The fry seem to select for size of food particle: they have been found not to feed on small particles less than
$<6.25$ micrometers $(\mu \mathrm{m})$, indiscriminately feed on mediumsized particles $(>6.25-11.25 \mu \mathrm{m})$, and prefer to feed on larger particles (>11.25-21.25 $\mu \mathrm{m})$ (Adamek and Spittler, 1984). Balasubramanian and others (1993) found that of three size groups of silver carp fingerlings - 1.2 gram (g), $5.4 \mathrm{~g}$, and $10.7 \mathrm{~g}$ - the 10.7-g size were the most effective at filtering bacteria from the water in a 12-hour period.

Studies done at the Marcalia reservoir near Lake Balaton in Hungary showed that silver carp prefer to feed on phytoplankton $>10 \mu \mathrm{m}$ and cannot take in phytoplankton smaller than $10 \mu \mathrm{m}$ because of the anatomy of their filtering apparatus (Vörös and others, 1997). Studies that compared silver and bighead carp diets to those of native filter feeders (bigmouth buffalo Ictiobus cyprinellus, gizzard shad Dorosoma cepedianum, and paddlefish Polyodon spathula) in the Illinois and Mississippi Rivers found the greatest dietary overlap between the Asian carps and gizzard shad. In contrast to bighead carp (439 to $1002 \mathrm{~mm}$ long), silver carp (261 to $798 \mathrm{~mm}$ long) tended to eat smaller prey (such as rotifers). Bigmouth buffalo and paddlefish tended to eat larger prey, and bighead carp and gizzard shad had a broader diet (Sampson and others, 2009).

As adults, silver carp are filter-feeding omnivores that consume both phytoplankton and detritus, though they seem to prefer phytoplankton. In one study, 97 percent of their diet was phytoplankton, and the remaining 3 percent was detritus

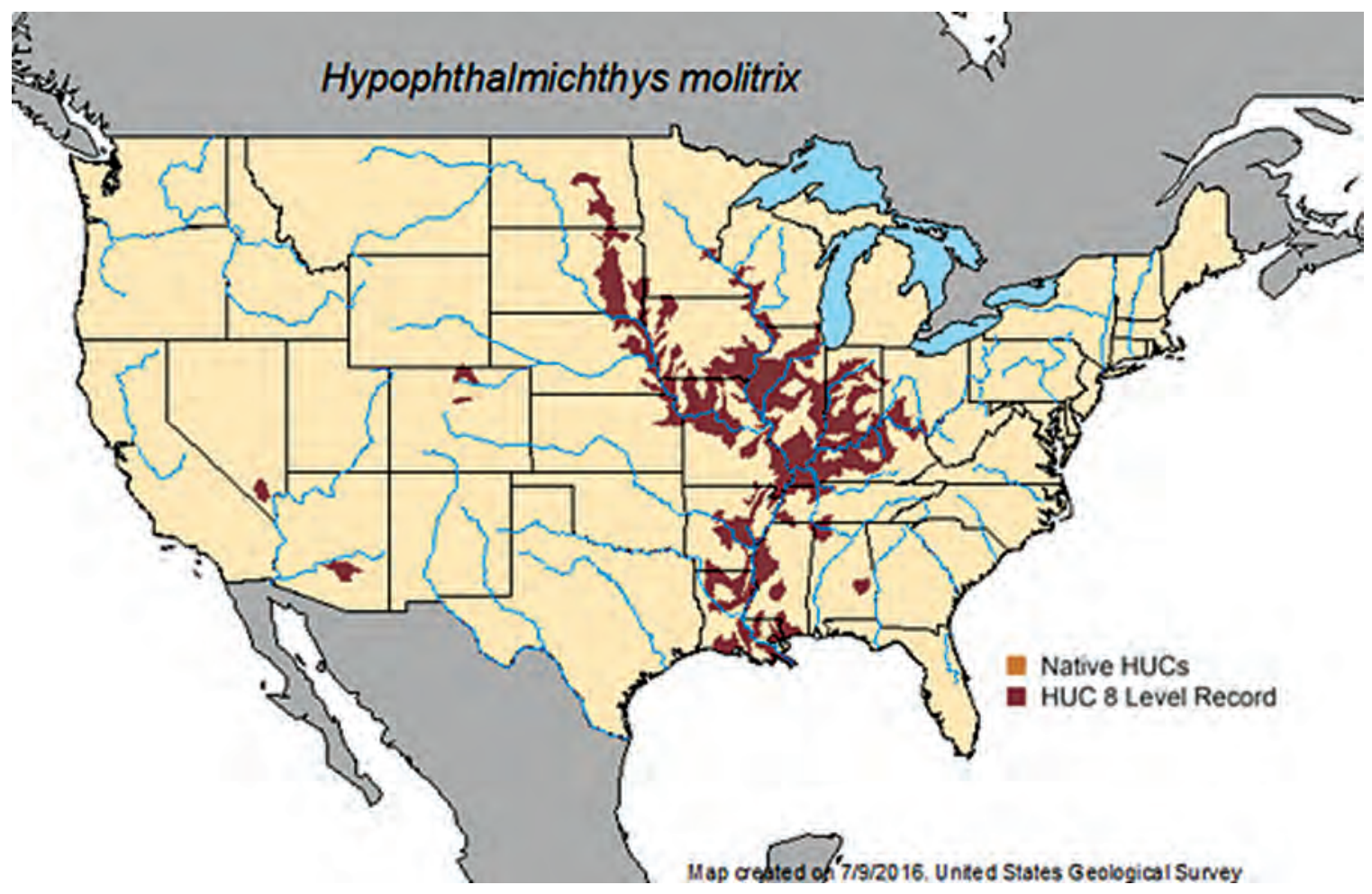

Figure 1-2. Distribution of silver carp in the United States (Source, U.S. Geological Survey Nonindigenous Aquatic Species database, http://nas.er.usgs.gov/queries/SpeciesMap.aspx?SpeciesID=549). (HUC, hydrologic unit code) 
(Adamek and Spittler, 1984). Adult fish also seem to select their food on the basis of particle size. Based strictly on size, there seem to be three different types of algae: non-available algae $(<10 \mu \mathrm{m})$, available-non-digestible algae $(>10 \mu \mathrm{m})$, and available-digestible algae $(>10 \mu \mathrm{m})$. Particles $<10 \mu \mathrm{m}$ were too small for the gill rakers of adult fish to trap, which makes such particles unavailable as a food source for those fish. In the gut analysis of adult silver carp, available-non-digestible algae were found in the greatest amount. This may cause that group of algae to be overestimated in importance. Conversely, available-digestible algae may be underestimated in the diet of silver carp because it is assimilated quickly in the gut (Vörös and others, 1997).

The gastrointestinal tract emptying time ranged from 10 hours at about $22{ }^{\circ} \mathrm{C}$ to about 108 hours at $4{ }^{\circ} \mathrm{C}$ (Bialokoz and Krzywosz 1981). Silver carp in the Missouri River were found to have full guts at water temperatures of $4{ }^{\circ} \mathrm{C}$, with a gut evacuation rate of 108 hours (Kolar and others, 2007). Larger fish may have slower evacuation times due to the longer intestinal length (Bialokoz and Krzywosz, 1981).

$\mathrm{Gu}$ and others (1996) used isotope analysis to determine the diet of silver and bighead carp fingerlings and found that silver carp may rely more on zooplankton than was previously thought. Their analysis suggests that the bighead and silver carp have over 50 percent overlap in their diets.

Three-year-old silver carp in Lake Paproteckie, Poland, significantly increased their size only during the spring and summer. In a study by Bialokoz and Krzywosz (1981), silver carp ceased to feed and growth rate was slowed at water temperatures $<15^{\circ} \mathrm{C}$. The authors estimated that $>90$ percent of the approximately 8-kg mass of food consumed by the test subject carp was consumed during the summer months.

\section{Habitats, Spawning Areas}

Spawning areas for bighead and silver carps are characterized by rapidly flowing, turbid water at temperatures between 18 and $30^{\circ} \mathrm{C}$ (Schrank and others, 2001). These sites are commonly found at confluences, among rocks in rapids, or behind sandbars or islands (Kolar and others, 2007). In the United States, there are reports of spawning by bighead and silver carps in the late summer and early fall based on collection of age- 0 fish in mid-August to mid-September in the Missouri River (Pfleiger, 1997). For spawning to occur, water temperature must exceed $18^{\circ} \mathrm{C}$ (Jennings, 1988) and water level must be rising (Conover, 2007; Kolar and others, 2007).

In both species, mating activity produces ripples on the surface of the water as the mating fish chase each other. In bighead carp, the male will often prod its head into the belly of a female, causing both fish to flip over, swim upside down, and release their gametes into the air. In silver carp, both males and females move to the surface of the water and release their gametes near the surface. If both species are present in the same river system, they will use similar spawning sites (Kolar and others, 2007).

\section{A. Bighead Carp}

Bighead carp reach sexual maturity in 3 to 4 years (Stone and others, 2000), though age at sexual maturity varies with environmental and climatic conditions. Fecundity of bighead carp increases with age and body weight (Jennings, 1988) and is directly related to growth rate (Verigin and others, 1990). An 18.5-kg female bighead carp can produce over 1 million eggs (Jennings, 1988). However, fecundity is often lower than this reported value in the United States. Bighead carp collected from the Missouri River in 1998 and 1999 averaged just over 226,000 eggs per female (Schrank and Guy, 2002). Spawning events may occur more than once per year. For example, Asian carp in the upper Mississippi River system spawned between June 4 and 10, 2005, and then again between August 19 and 22,2005 . Spawning coincided with rising discharge in both time periods (Lohmeyer and Garvey, 2008).

It has generally been believed that bighead carp have very specific spawning requirements, preferring large, turbid rivers and rising water for spawning, and that they do not spawn in still waters or small streams (Kolar and others, 2007). Yi and others (1988) reported that in their native Yangtze River, the carp used only 36 specific spawning sites. Once the water levels rise, the adults will migrate upstream to the spawning areas, which include rapidly flowing water (Schrank and others, 2001). Bighead carp spawn is released in rapids, in river channels, behind sand bars, and at islands at the junction of currents (Jennings, 1988). Recent work by Deters and others (2012) on the Missouri River suggests that the carp are not as selective and found evidence of spawning in nearly all reaches of the river examined, including the more sinuous parts of the river. There is also growing evidence that rising water is not a spawning trigger (Kolar and others, 2007; Coulter and others, 2013). Optimal temperature for reproduction of bighead carp is between 22 and $25.5^{\circ} \mathrm{C}$, and water temperature must be above $18{ }^{\circ} \mathrm{C}$ (Jennings, 1988). After spawning, bighead carp migrate to floodland lakes (Jennings, 1988). Water velocity to induce spawning must be greater than 0.8 meter per second (m/s) (Jennings, 1988).

\section{B. Silver Carp}

The age at which silver carp sexually mature varies depending on the water system and appears to be linked to water temperature (Kolar and others, 2007). Males can reach sexual maturity when they are 2 years old, but females do not become mature until years 3 or 4, around the size of $2-5 \mathrm{~kg}$ (Conover and others, 2007). In the Middle Mississippi River, silver carp seemed to reproduce 1 year earlier (by age 2) than in their native ranges in China.

Fecundity of silver carp, like that of the bighead carp, is high and increases with body size (Kolar and others, 2007). In a study done on the Middle Mississippi River in 2003, fecundity of 2 year-old silver carp ranged from about 57,000 eggs to 328,000 eggs (Williamson and Garvey, 2005). 


\section{Life Cycle and Early Development}

Eggs of all Asian carp are semi-buoyant and require flowing water to remain in suspension during development (Stanley and others, 1978; Jennings, 1988; Conover and others, 2007). The specific gravity of fertilized eggs for both bighead and silver carps has been found to be very low, about 1.005 , when they are fully water hardened after about 4 hours. Most of the decrease in specific gravity occurs during the first half hour. Contradictory to previous reports, larvae of both species were observed to not settle but to start vertical swimming immediately post hatch. Larvae were found to begin horizontal swimming (and start to appear in off-channel habitats (Deters and others, 2012)) just before gas bladder inflation, which occurs in silver carp at approximately 109 hours post fertilization at $22.5^{\circ} \mathrm{C}$ and about 160 hours at $19.5^{\circ} \mathrm{C}$ (Chapman and George, 2011).

Larvae of bighead and silver carps were sampled in pools 20-26 and in the open water of the Mississippi River near Chester, Illinois, in 2005, 2006, and 2007. Larval abundance increased in the spring when the water level was high and rising. Water velocity in the upstream section of pools was adequate for inducing spawning $(0.78 \mathrm{~m} / \mathrm{s})$, but velocity downstream of dams in the pools was lower $(0.52 \mathrm{~m} / \mathrm{s})$, especially in dry years of 2005 and 2006, and may have limited larval production (Lohmeyer and Garvey, 2008). In 2005 and 2006, which are considered to have been dry years, water-level management of the Upper Mississippi River limited the production of larvae of both bighead and silver carps. However, in the open stretches of the river, production of larvae was abundant. These larvae may then have moved into pools to replenish the downstream populations (Lohmeyer and Garvey, 2008).

\section{A. Development}

Chapman and George (2011) detail the developmental timeline for silver and bighead carps at a cold temperature and a warm temperature and provide a photographic atlas of the different developmental stages. In their study, the cold temperature was $20.1{ }^{\circ} \mathrm{C}$ for bighead carp and $19.6{ }^{\circ} \mathrm{C}$ for silver carp, and the warm temperature was $22.5^{\circ} \mathrm{C}$ for bighead carp and $22.3{ }^{\circ} \mathrm{C}$ for silver carp. As might be expected, both species developed faster at warmer temperatures but were significantly smaller at hatching in warmer water (Chapman and George, 2011). Both species also displayed strong vertical swimming upon hatch, and both species displayed horizontal swimming when the gas bladder developed (Chapman and George, 2011). In the wild, bighead larvae at hatch move downstream to areas of quieter water that provide a nursery area. The prolarval phase was found to end about day 3 post hatch, and larvae were about 5.5 to $6 \mathrm{~mm}$ long. Prolarvae are motile but typically carried by water currents (Jennings, 1988). The mesolarval stage, 4 to 5 days post hatch, is characterized by gill respiration and increased mobility where the larvae will swim to feed. At day 7, the larval fish begin to migrate along the shore. By day 20 to 28 , their paired fins are well developed, fin rays have formed, and they preferentially feed on zooplankton, especially Cyclops sp. (Jennings, 1988). When bighead larvae reach a length of 7 to $9 \mathrm{~mm}$, protozoa and zooplankton are their primary food source. They begin to eat phytoplankton at 18 to $23 \mathrm{~mm}$. In the postlarval phase, they develop scales at about day 30 and reach a body weight of 0.75 to $1.5 \mathrm{~kg}$ by year 2 (Jennings, 1988). More recent investigations conducted by USGS have better defined the relation between temperature and developmental rate (D.C. Chapman and A.E. George, U.S. Geological Survey, unpublished data).

\section{Threats and Invasion Risks}

\section{A. Effects on Invaded Ecosystems}

The unintentional introduction of Asian carps into waters of the United States has generally caused problems because Asian carps can alter the natural populations of phytoplankton and zooplankton, the effects of which ripple through other aquatic organisms. Kolar and others (2007) provide an indepth review of the literature concerning effects of the introduction of bigheaded carps on zooplankton and phytoplankton. For example, when bighead and silver carps were stocked into Lake Donghu, China, cyanobacteria and large daphnids decreased, allowing more of the smaller algae to grow (Tang and others, 2005). Similarly, mesocosms without bighead carp had higher levels of Daphnia compared to mesocosms with bighead carp (Cooke and others, 2009). Xie and Yang (2000) found that filter-feeding fish, including bighead and silver carp, caused an increase in the ratio of the predaceous cyclopoids to herbivorous calanoids in a Chinese lake from 1957 to 1996. Filter-feeding fish appeared not to affect the cyclopoids and their populations were, at times, enhanced.

Bighead carp can filter smaller particles out of the water if larger zooplankton are not available (Xie and Liu, 1994). When smaller particles are found in the gut of bighead carp, it suggests that food availability is worsening and that the lake ecosystem is at carrying capacity for the fish (Xie and Liu, 1994). Although bighead carp are not as efficient at capturing small algae, they can filter out some of them (Xie, 2001). Lu and Xie (2001) found that if there is heavy predation pressure on zooplankton by bighead and silver carp, those planktonic species that can recover quickly are more likely to survive.

Silver carp were intentionally stocked into Lake Kinneret in Israel to try to control phytoplankton. The amount of bluegreen algae did decrease, but the composition of the zooplankton communities also was altered. Furthermore, there was a decrease in zooplankton, likely the result of high predation pressure from silver carp (and other species). This allowed nanoplankton biomass to increase, which had a negative effect on the water quality of the lake, described as an "ichthyoeutrophication" process (Spataru and Gophen, 1985).

Diet preferences of bighead (and silver) carp can shift depending on density and competition for food. In China, 
bighead and silver carps were stocked into Meiling Bay of Lake Taihu to help control cyanobacterial blooms. When competition for food was low, both species fed on zooplankton. However, when competition was higher, the diet of silver carp shifted to phytoplankton. At lower densities, consumption of zooplankton might mitigate the carps' effectiveness at controlling cyanobacterial blooms (Ke and others, 2008). The unintentional introduction of Asian carp into waterways of the United States can have far-reaching ecological effects through food-chain perturbations. A major effect on the ecosystem as a result of bighead carp invasion is the potential to adversely affect native populations at all life stages (Conover and others, 2007). Because bighead carp feed primarily on plankton, which forms the base of the food web, the presence of bighead carp in waterways can adversely affect native populations of mussels, larval fish, and adult fish that also rely on plankton as a food source.

The ability of Asian carp to alter phytoplankton and zooplankton populations may also cause ecosystem perturbation through the reduction in essential lipids in native fish populations. Lipids play important roles in the physiology of fish and also indicate food sources upon which the fish depend. A recent study conducted in Pools 8 and 26 of the Mississippi River and the LaGrange Pool of the Illinois River found that overall lipid content in native fish, with the exception of bluegill, decreased when the native fish shared habitats with bighead and silver carps. Specific lipids of concern included heptadecanoic acid, eicosapentaenoic (EPA) acid, docosahexaenoic (DHA) acid, $\alpha$-linolenic (ALA) acid, arachidonic acid, linoleic acid, oleic acid, and stearic acid. Both EPA and DHA are critical to fish egg development and survivability. ALA is a precursor to EPA and DHA in invertebrates. Levels of EPA, DHA, and ALA decreased in native fish (exception bluegill) when they shared habitat with Asian carp. The lowered levels of these fatty acids have the potential to adversely affect the successful reproduction of native fish species (Steve Gutreuter, U.S. Geological Survey, oral commun., 2012).

In addition to the above impacts, silver carp pose a threat to human safety because they jump from the water when disturbed, particularly by the vibrations of motor boat engines (Conover and others, 2007). Such behavior has the potential to alter recreational activities on the water.

It is likely that the range of Asian carp will continue to expand. A study by DeGrandchamp and others (2008) examined the movements of bighead and silver carp in the Illinois River, an important link between the Mississippi River and Lake Michigan. They tagged 25 bighead carp and 21 silver carp in 2004 and 35 bighead carp and 32 silver carp in 2005 and released them into the Illinois River. They found that the fish mostly moved upstream from the point of release and that the movements correlated with the river stage, suggesting stage may be a cue for movement. Increasing water temperature was negatively correlated to movement, indicating that movement was more influenced by river stage. The carps' dispersal rate and range were comparable to the rates and ranges of movement of fish native to the Mississippi River. Both species seemed to prefer similar habitats and may coexist by partitioning food resources, bighead carp feeding more on zooplankton and silver carp feeding preferentially on phytoplankton. Both species tended to avoid the main channel, perhaps because of lower food availability and the energetic demand of living in rapidly flowing water. Additionally, both species tended to be found at a depth of $\leq 4 \mathrm{~m}$ (DeGrandchamp and others, 2008). This suggests that Asian carp occupy the same habitats as native fish and, once established, can likely outcompete them for resources.

\section{B. Threats if Range Continues to Expand}

A main area of concern is where the Des Plaines River parallels the CSSC (www.asiancarp.org). These two waterways are quite close for about $13 \mathrm{mi}$, especially around the area of the electric fish barrier (fig. 1-3). Hoffman dam, which is about 12 miles (mi) upstream of the electric fish barrier, may provide a suitable spawning habitat for Asian carps. Surveys done in the spring of 2010 found no eggs in the area, and no confirmed catches of Asian carp have been reported for that area. However, positive environmental DNA (eDNA) samples have been found in this part of the river (Ryan Jackson, U.S. Geological Survey, oral commun., 2011).

The Des Plains River flows for about $150 \mathrm{mi}$, from southern Wisconsin through northeastern Illinois. The Kankakee River and Des Plaines River combine to form the Illinois River, which generally flows southwest eventually connecting to the Mississippi River (Kozak and others, 2010). The close proximity of the Des Plaines River to the CSSC creates a potential avenue of spread of Asian carp from the Des Plaines River into Lake Michigan during a flooding event. Levees and fences (funded by the U.S. Environmental Protection Agency) were built between the river and the CSSC to prevent movement of juvenile or adult Asian carp between the two systems; however, larvae or eggs may still be able to traverse the fence during a flood event.

Another concern regarding this location is the numerous rock fractures reported in the bedrock that separates the Des Plaines River and the shipping channel, some of which are more than $0.5 \mathrm{~m}$ wide along outcrops at the streambanks and canal excavations. These fractures may provide a connection between the two waterways such that eggs, larvae, or fry can move from the Des Plaines River into the shipping channel and eventually reach Lake Michigan (Brammeier and others, 2008). The U.S. Geological Survey Upper Midwest Environmental Sciences Center conducted a comprehensive literature search with the ultimate goal of determining what has been published regarding movement of eggs, larvae, and fry of Asian carp and other fish species through rock fractures. An initial search conducted prior to focusing on movement through rock fractures collected all available information on Asian carps. The key terms used included "grass carp" or "black carp" or "silver carp" or "asian carp" or "bighead carp" and hypophthalmichthys, planktivore, and cyprinid. 


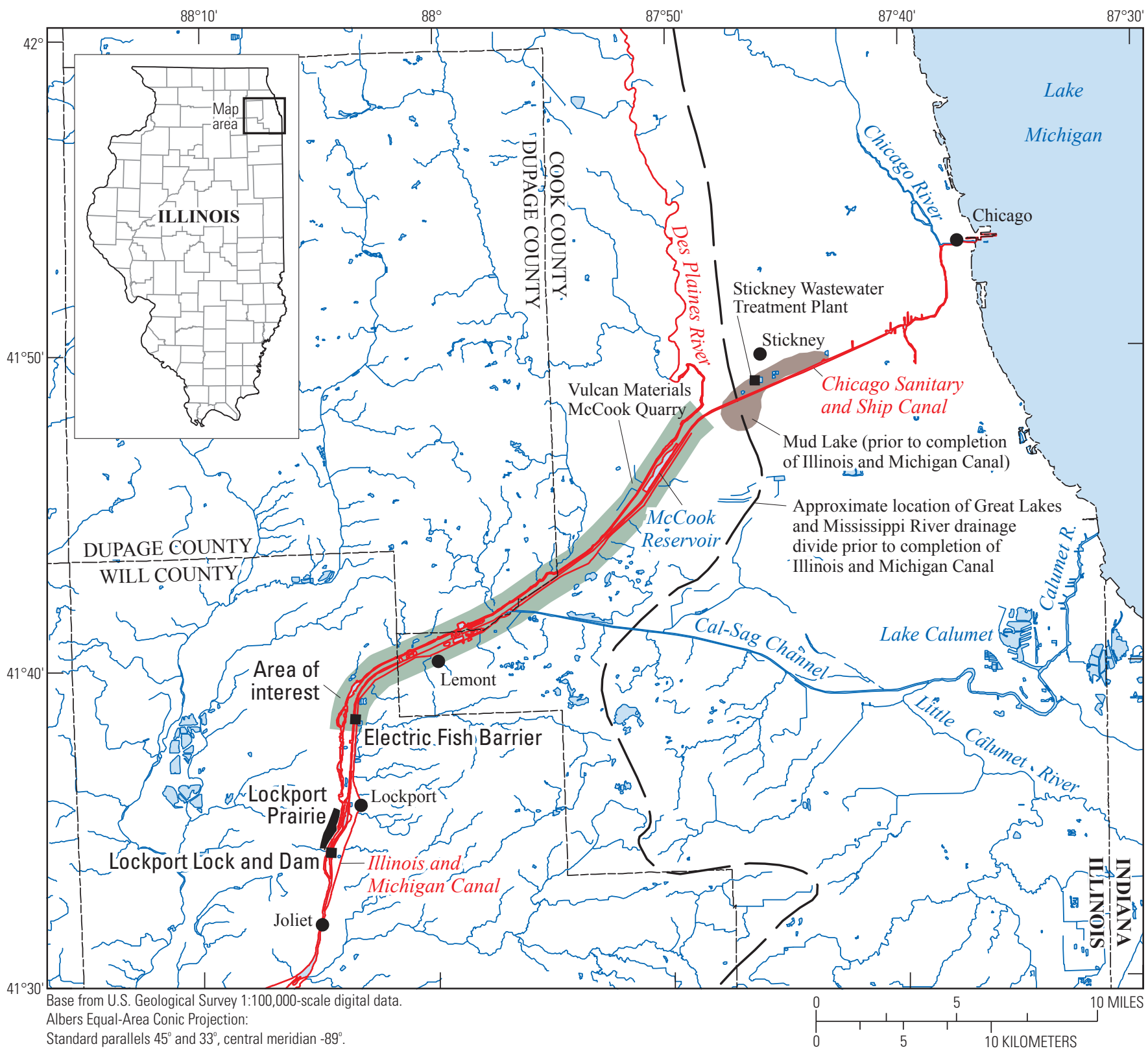

Figure 1-3. Location of the Des Plaines River, Chicago Sanitary and Ship Channel, and selected features in northeastern Illinois. Note the close proximity of the two waterways.

The databases searched were ISI Web of Knowledge and Cambridge Scientific Abstracts. This initial search found 412 articles and books related to the search terms. Reviews of abstracts for relatedness to the subject of Asian carp biology narrowed the list to about 62 of the references, which were obtained and read. No information was found specifically on movement of Asian carp eggs, larvae, or fry through rock fractures.
Because no information specific to Asian carp eggs or larval movement through rock fractures was found, a second expanded search was conducted to include other fish species using these databases: ISI Web of Knowledge, Cambridge Scientific Abstracts, EBSCO Host Databases, SCOPUS Abstract Database, and Bio-one Abstracts. Search terms included "prolarval movement"/crevices, "juvenile fish movement"/crevices, "juvenile fish movement"/fissures, "larval fish 
movement"/fissures, "larval fish drift," "larval fish migration," karst, "fish movement"/karst, "larval fish movement"/karst, and "rock fractures"/fish. That search identified one paper on brook trout (Salvelinus fontinalis) movement through a gabion barrier. In that study, marked brook trout were released into three streams downstream of rock-filled gabion barriers to determine whether such barriers would prevent their movement upstream. In two of the streams, no fish moved upstream. These gabions were filled with smaller diameter rocks. In the third stream, 18 of 86 marked fish (ranging in size from 81 to $224 \mathrm{~mm}$ ) were recovered upstream of the gabion barrier. One fish $(162 \mathrm{~mm})$ moved through the barrier twice, the second time during a low-flow year, suggesting the fish likely moved through the crevices in the barrier where silt and gravel had not filled them in (Thompson and Rahel, 1998).

A preliminary study of the karstic structure of the area between the Des Plaines River and the canal suggests that fracturing in this area has not occurred to an extent that would connect the two waterways. At most, the fractures extend inward about 10 feet, and the lowermost vertical extent of the fractures was down to the water surface (see main body of report). Another important consideration is that fry tend to be phototactic; that is, they are drawn to light. This is likely because they associate food with light. Insufficient research has been done on bighead and silver carp larvae to conclude that the larvae are phototactic. Based on available information, even if a connecting fracture did exist, it is unlikely that fry would move toward the low- or no-light conditions expected to be present in bedrock fractures (Duane Chapman, U.S. Geological Survey, oral commun., 2012). The distance between the river and the canal at some of the narrowest points is about 250 to 300 feet.

No search was conducted on eDNA moving through rock fractures. As of now, it is unknown whether eDNA could move through rock fractures. Current research using eDNA surveillance in the CAWS found DNA from both silver and bighead carps upriver of an electric barrier that was designed to prevent their movement upstream (see maps at the end of this Appendix). Though current eDNA methods do not provide conclusive evidence of the presence of a live organism, they do confirm the presence of the DNA of the target species. Various potential vectors of Asian carp eDNA and their capacity to move the eDNA are presently being evaluated (for example, a fish hitting the bottom of a boat might leave tissue adhering to the hull). The DNA of silver carp was detected in the Calumet Harbor of Lake Michigan, and DNA from bighead carp was detected in Lake Calumet within $13 \mathrm{~km}$ of Lake Michigan. On June 22, 2010, a commercial fisherman caught a bighead carp in the Calumet River only $4 \mathrm{~km}$ upstream from the nearest positive eDNA detection, which was above the electric barrier (Jerde and others, 2011).

\section{References Cited}

Adamek, Z., and Spittler, P., 1984, Particle size selection in the food of silver carp, Hypophthalmichthys molitrix: Folia Zoologica, v. 33, no. 4, p. 363-370.

American Sportfishing Association, 2008, Today's anglerA statistical profile of anglers, their targeted species and expenditures: Alexandria, Va., 216 p.

Balasubramanian, S., Rajan, M.R., and Raj, S.P., 1993, Bacterial filtration by silver carp (Hypophthalmichthys molitrix): Journal of Aquaculture in the Tropics, v. 8, p. 231-237.

Bialokoz, W., and Krzywosz, T., 1981, Feeding intensity of silver carp (Hypophthalmichthys molitrix Val.) from the Paproteckie Lake in the annual cycle: Ekologia Polska, v. 29 , no. 1, p. 53-61.

Brammeier, J., Polls, I., and Mackey, S., 2008, Preliminary feasibility of ecological separation of the Mississippi River and the Great Lakes to prevent the transfer of aquatic invasive species: Great Lakes Fishery Commission, p. 86-87.

Chapman, D.C., and George, A.E., 2011, Developmental rate and behavior of early life stages of bighead carp and silver carp: U.S. Geological Survey Scientific Investigations Report 2011-5076, 62 p.

Clapp, D., Mistak, J., Smith, K., and Tonelto, M., 2010, Proposed plan for the prevention, detection, assessment, and management of Asian carp in Michigan water: Michigan Department of Natural Resources, Management Plan for Asian Carps.

Conover, G., Simmonds, R., and Whalen, M., eds., 2007, Management and control plan for bighead, black, grass, and silver carps in the United States: Washington D.C., Aquatic Nuisance Species Task Force, Asian Carp Working Group, $223 \mathrm{p}$.

Cooke, S.L., Hill, W.R, and Meyer, K.P., 2009, Feeding at different plankton densities alters invasive bighead carp (Hypophthalmichthys nobilis) growth and zooplankton species composition: Hydrobiologia, v. 625, no. 1, p. 185-193.

Coulter, A., Keller, D., Amberg, J.J., Bailey, E.J., and Goforth, R.R., 2013, Phenotypic plasticity in the spawning traits of bigheaded carp (Hypopthalmichthys spp.) in novel ecosystems: Freshwater Biololgy, 9 p, doi:10.1111/fwb.12106.

Cremer, M.C., and Smitherman, R.O., 1980, Food habits and growth of silver and bighead carp in cages and ponds: Aquaculture, v. 20, no. 1, p. 57-64. 
Cudmore, B., Mandrak, N.E., Dettmers, J.M., Chapman, D.C., and Kolar, C.S., 2012, Binational ecological risk assessment of bigheaded carps (Hypophthalmichthys spp.) for the Great Lakes Basin: Fisheries and Oceans Canada, Research Document 2011/114.

DeGrandchamp, K.L., Garvey, J.E., and Colombo, R.E., 2008, Movement and habitat selection by invasive Asian carps in a large river: Transactions of the American Fisheries Society, v. 137, no. 1, p. 45-56.

Deters, J.E., Chapman, D.C., and McElroy, B., 2012, Location and timing of Asian carp spawning in the Lower Missouri River: Environmental Biology of Fishes, 13 p., http://dx.doi. org/10.1007/s10641-012-0052-z.

Dong, Shuanglin, and Li, Deshang, 1994, Comparative studies on the feeding selectivity of Silver carp Hypophthalmichthys molitrix and bighead carp Aristichthys nobilis: Journal of Fish Biology, v. 44, no. 4, p. 621-626.

Gu, B.H., Schell, D.M., Huang, X.H., and Yie, F.L., 1996, Stable isotope evidence for dietary overlap between two planktivorous fishes in aquaculture ponds: Canadian Journal of Fisheries and Aquatic Sciences, v. 53, no. 12, p. 2814-2818.

Hansen, M., 2010, The Asian carp threat to the Great Lakes: Washington D.C., Testimony to House Committee on Transportation and Infrastructure, Subcommittee on Water Resources \& Environment.

Jennings, D.P., 1988, Bighead carp (Hypophthalmichthys nobilis)_A biological synopsis: Biological Report, v. 88, no. 29,183 p.

Jerde, C.L., Mahon, A.R ., Chadderton, W.L., and Lodge, D.M., 2011, "Sight unseen" detection of rare aquatic species using environmental DNA: Conservation Letters, v. 4, no. 2, p. $150-157$.

Ke, Z.X., Xie, P., Guo, L.G., Liu, Y.Q., and Yang, H., 2007, In situ study on the control of toxic Microcystis blooms using phytoplanktivorous fish in the subtropical Lake Taihu of China-A large fish pen experiment: Aquaculture, v. 265, no. $1-4$, p. $127-138$.

Ke, Z., Xie, P., and Guo, L., 2008, In situ study on effect of food competition on diet shifts and growth of silver and bighead carps in large biomanipulation fish pens in Meiliang Bay, Lake Taihu: Journal of Applied Ichthyology, v. 24, no. 3, p. 263-268.
Kelly, A.M., Engle, C.R. , Armstrong, M.A., Freeze, M., and Mitchell, A. J., 2011, History of introductions and governmental involvement in promoting the use of grass, silver, and bighead carps, in Chapman D.C., and Hoff, M.H., eds., Invasive Asian carps in North America: Bethesda, Md., American Fisheries Society.

Kolar, C.S., Chapman, D.C., Courtenay, W.R., Housel, C.M., Williams, J.D., Jennings, D.P., 2007, Bigheaded carpsA biological synopsis and environmental risk assessment: Bethesda, Md., American Fisheries Society Special Publication 33, 204 p.

Kozak, J., Lant, C., Shaikh, S., and Wang, G., 2010, The geography of ecosystem service value-The case of the Des Plaines and Cache River wetlands, Illinois: Applied Geography, v. 31, p. 303-311.

Lohmeyer, A., and Garvey, J., 2008, Placing the North American invasion of Asian carp in a spatially explicit context: Biological Invasions, v. 11, no. 4, p. 905-916, doi:10.1007/s10530-008-9303-5.

Lu, Min, and Xie, Ping, 2001, Impacts of filter-feeding fishes on the long-term changes of crustacean zooplankton in a eutrophic subtropical Chinese lake: Journal of Freshwater Ecology, v. 16, no. 2, p. 219-228.

Lu, M., Xie, P., Tang, H.J., Shao, Z.J., and Xie, L.Q., 2002, Experimental study of trophic cascade effect of Silver carp (Hypophthalmichthys molitrixon) in a subtropical lake, Lake Donghu - On plankton community and underlying mechanisms of changes of crustacean community: Hydrobiologia, v. 487 , no. 1 , p. 19-31.

Morrison, B.J., Casselman, J.C., Johnson, T.B., and Noakes, D.L., 2004, New Asian carp genus (Hypophthalmichthys) in Lake Erie: Fisheries, v. 29, no. 8, p. 6-7.

Opuszynski, K., and Shireman, J.V., 1993, Food habits, feeding behaviour and impact of triploid bighead carp, Hypophthalmichthys nobilis, in experimental ponds: Journal of Fish Biology, v. 42, no. 4, p. 517-530.

Oregon Sea Grant, 2010, Aquatic Invasion! A menace to the West-Species guide, Asian Carps: 11 p.

Patel, A.G., Glassner-Shwayder, K., and Eder, T., 2010, Halting the invasion-Maintaining health of the Great Lakes and Mississippi River basin by preventing further exchange of aquatic invasive species: Environmental Practice, v. 12, p. 342-356.

Pflieger, W.L., 1997, The fishes of Missouri (2d ed.): Jefferson City, Mo., Missouri Department of Conservation, 372 p. 
Rai, A.K., 2000, Evaluation of natural food for planktivorous fish in Lakes Phewa, Begnas, and Rupa in Pokhara Valley, Nepal: Limnology, v. 1, p. 81-89.

Sampson, S.J., Chick, J.H., and Pegg, M.A., 2009, Diet overlap among two Asian Carp and three native fishes in backwater lakes on the Illinois and Mississippi Rivers: Biological Invasions, v. 11, no. 3, p. 483-496.

Schrank, S.J., Braaten, P.J., and Guy, C.S., 2001, Spatiotemporal variation in density of larval bighead carp in the lower Missouri River: Transactions of the American Fisheries Society, v. 130, p. 809-814.

Schrank, S.J., and Guy, C.S., 2002, Age, growth, and gonadal characteristics of adult bighead carp, Hypophthalmichthys nobilis, in the lower Missouri River: Environmental Biology of Fishes, v. 64, p. 443-450.

Spataru, P., and Gophen, M., 1985, Feeding behavior of silver carp Hypophthalmichthys molitrix Val. and its impact on the food web in Lake Kinneret, Israel: Hydrobiologia, v. 120, p. 53-61.

Stanley, J.G., Miley, W.W., II, and Sutton, D.L., 1978, Reproductive requirements and likelihood for naturalization of escaped grass carp in the United States: Transactions of the American Fisheries Society, v. 107, p. 119-128.

Stone, N., Engle, C., Heikes, D., and Freeman, D., 2000, Bighead carp: Southeast Regional Aquiculture Center, publication no. 438, 4 p.

Tang, H., Xie, P., and Hong, L., 2005, Changes in the phytoplankton community of Lake Donghu since the 1980s: Journal of Freshwater Ecology, v. 20, no. 3, p. 591-594.

Thompson, D., and Rahel, F., 1998, Evaluation of artificial barriers in small Rocky Mountain streams for preventing the upstream movement of brook trout: North American Journal of Fisheries Management, v. 18, p. 206-210.
Verigin, B.V., Shakha, D.N., and Kamilov, B.G., 1990, Correlation among reproductive indicators of the silver carp, Hypophthalmichthys molitrix, and the bighead, Aristichthys nobilis: Journal of Ichthyology, v. 30, no. 8, p. 80-92.

Vörös, L., Oldal, I., Presing, M., and Balogh, K.V., 1997, Sizeselection filtration and taxon-specific digestion of plankton algae by silver carp (Hypophthalmichthys molitix Val.): Hydrobiologia, v. 342/343, p. 223-228.

Williamson, C.J., and Garvey, J.E., 2005, Growth, mortality, and fecundity of newly established silver carp in the middle Mississippi River: Transactions of the American Fisheries Society, v. 134, p. 1423-1430.

Xie, P., 2001, Gut contents of bighead carp (Aristichthys nobilis) and the processing and digestion of algal cells in the alimentary canal: Aquaculture, v. 195, no. 1-2, p. 149-161.

Xie, P., and Liu, J., 1994, Phytoplankton, especially diatoms, in the gut contents and feces of two planktivorous cyprinids - Silver carp and bighead carp: Chinese Journal of Oceanology and Limnology, v. 12, no. 4, p. 308-315.

Xie, P., and Yang, Y, 2000, Long-term changes of Copepoda community (1957-1996) in a subtropical Chinese lake stocked densely with planktivorous filter-feeding silver and bighead carp: Journal of Plankton Research, v. 22, no. 9, p. $1757-1778$.

Yi, B., Yu, Z., Liang, Z., Sujuan, S., Xu, Y., Chen, J., He, M., Liu, Y., Hu, Y., Deng, Z., Huang, S., Sun, J., Liu, R., and Xiang, Y., 1988, The distribution, natural conditions, and breeding production of the spawning ground of four famous freshwater fishes on the main stream of the Yangtze River, in Yi, B., Yu, Z., and Liang, Z., eds., Gezhouba water control project and four famous fishes in the Yangtze River: Wuhan, Hubei Science and Technology Press, p. 1-46. (In Chinese with English abstract) 
Addendum 1. Asian Carp Regional Coordinating Committee (ACRCC) Monitoring and Rapid Response Work Group (MRRWG) Asian carp eDNA surveillance, December 28, 2010, to July 24, 2012-status maps.
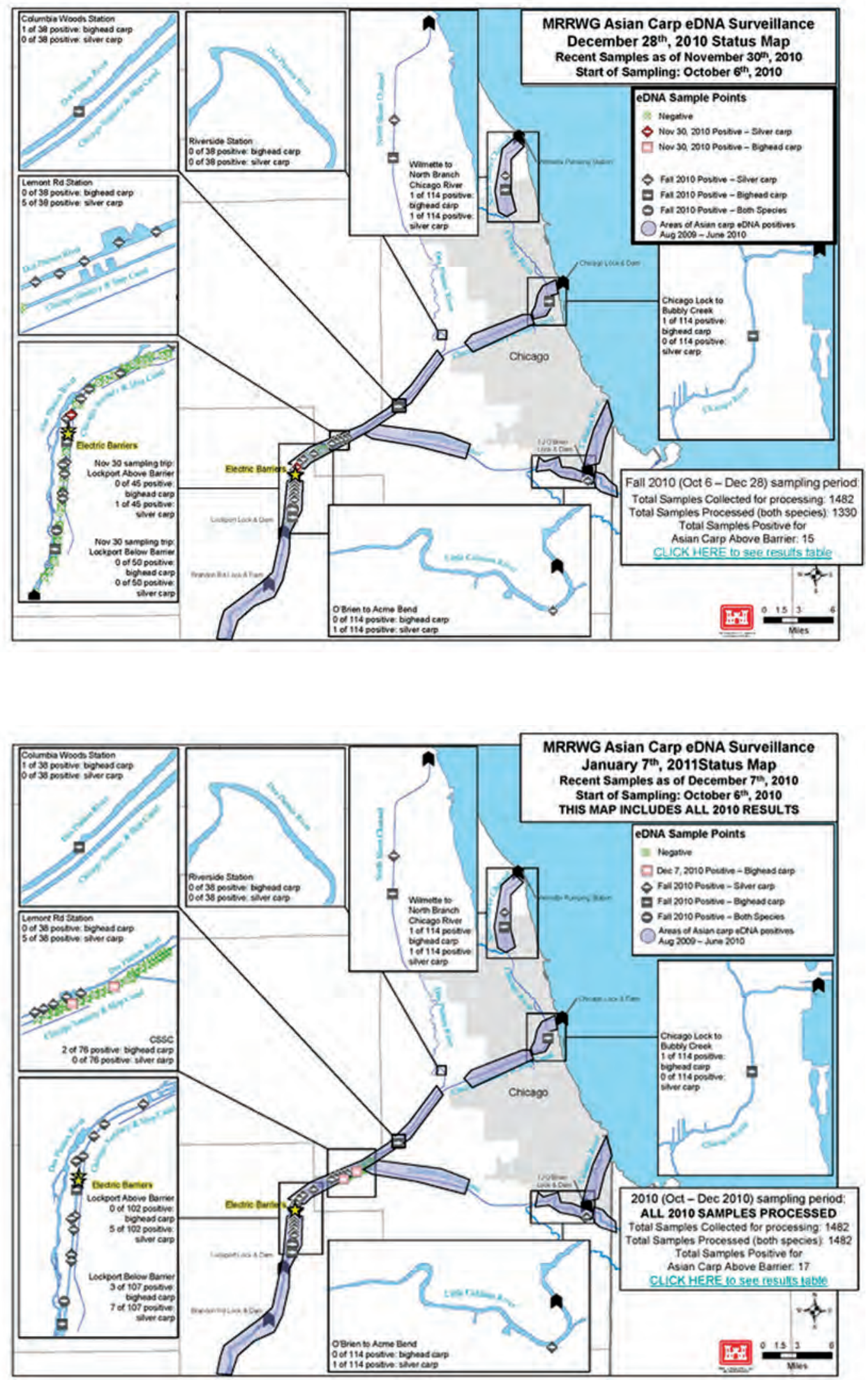

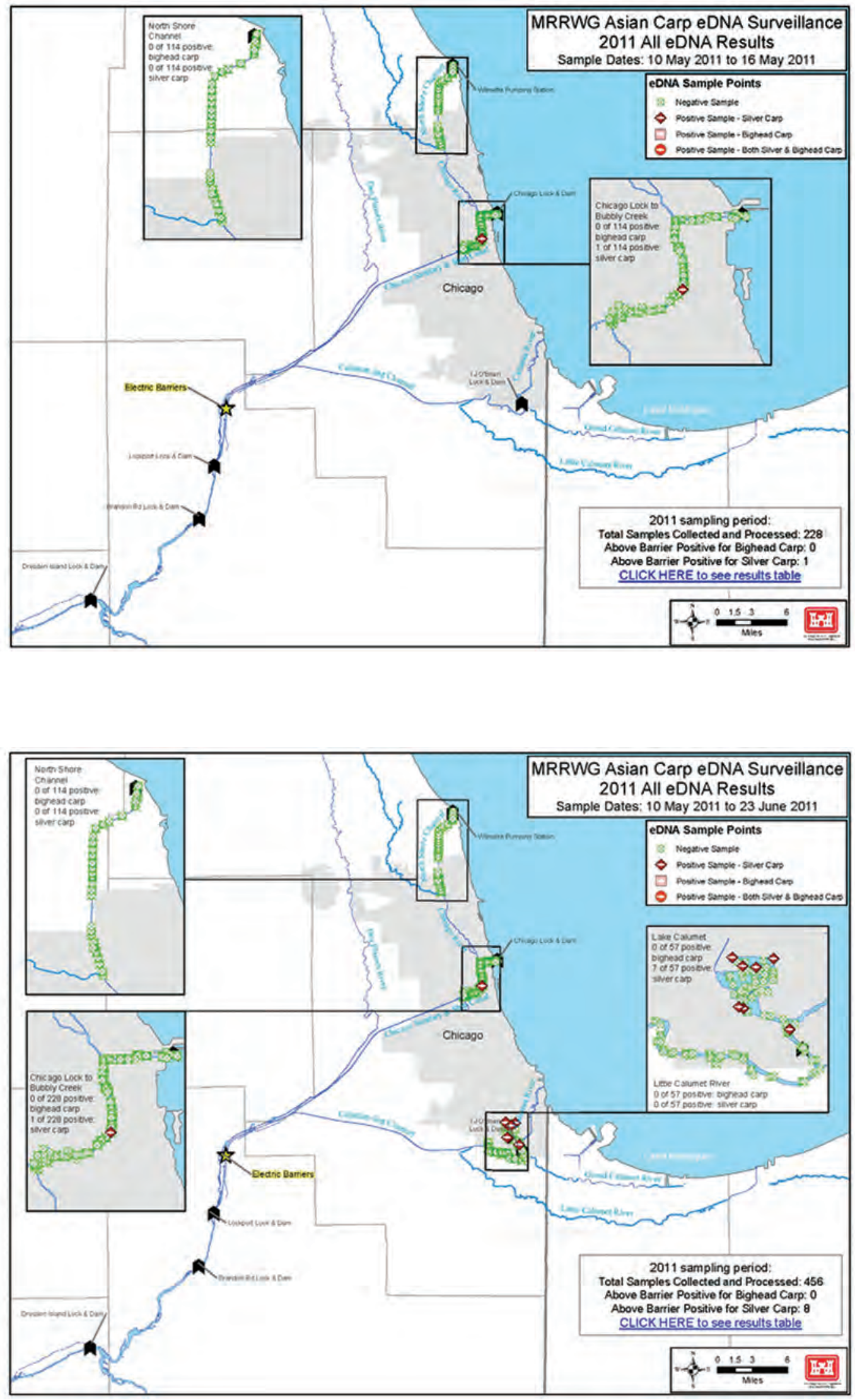

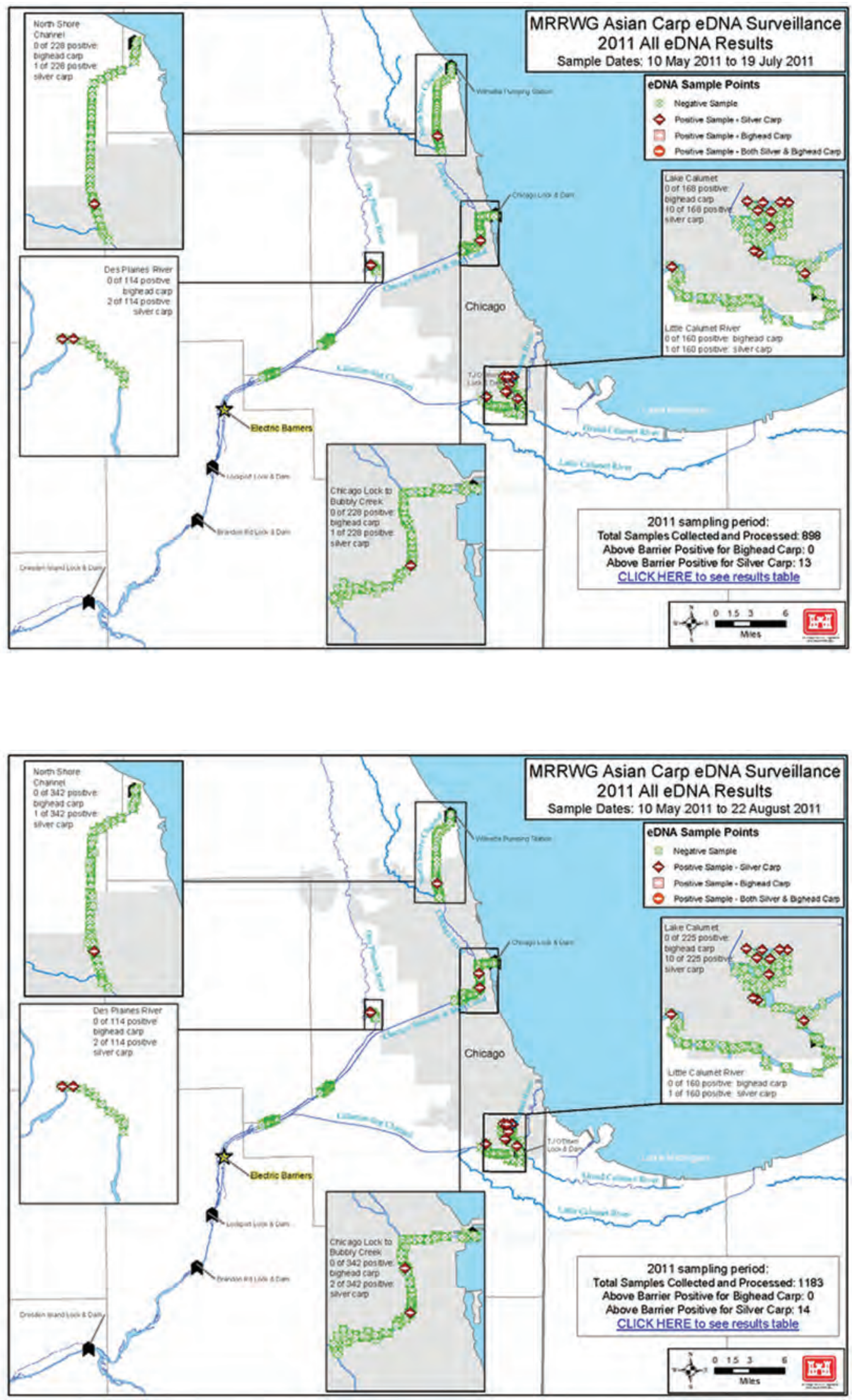

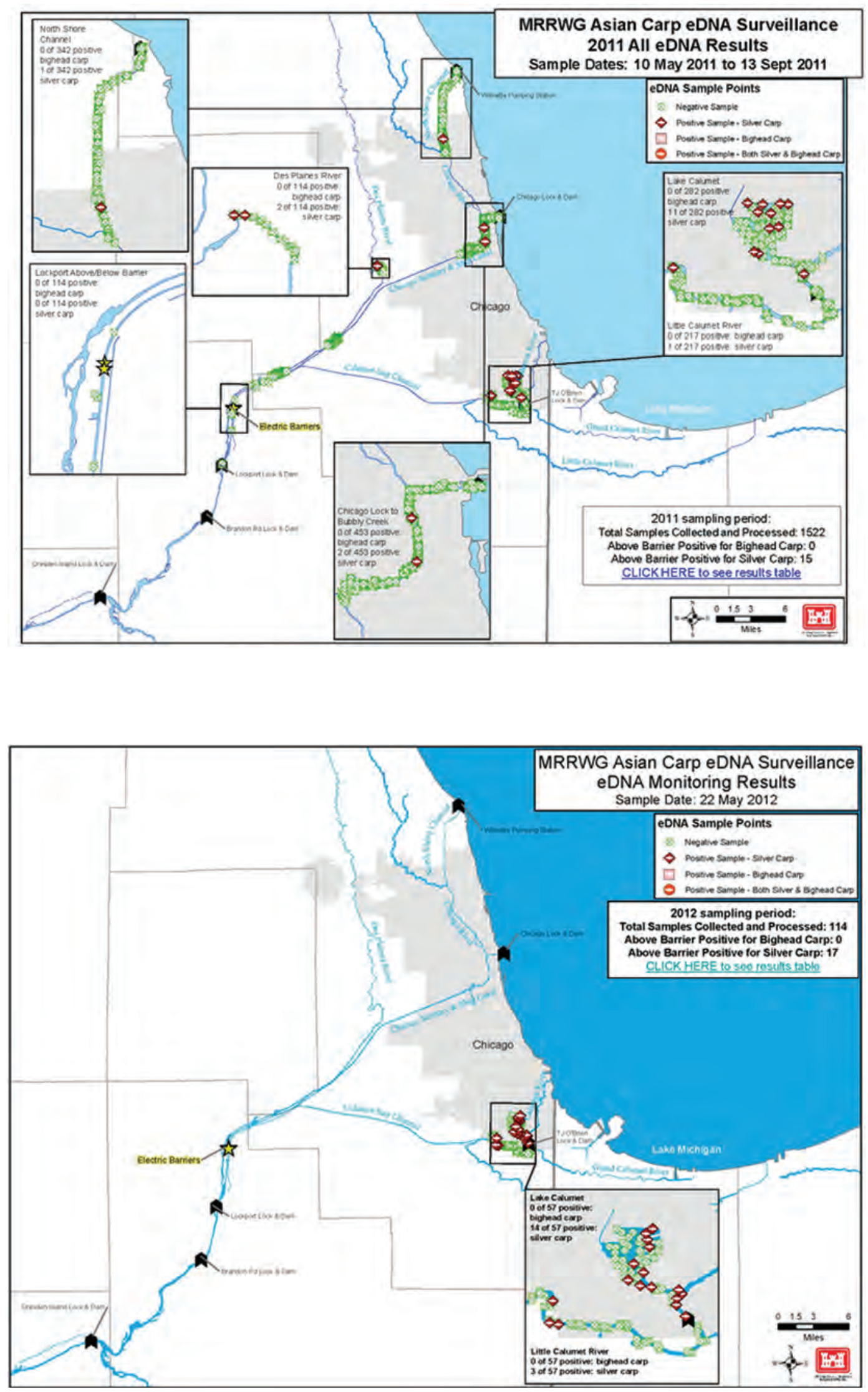

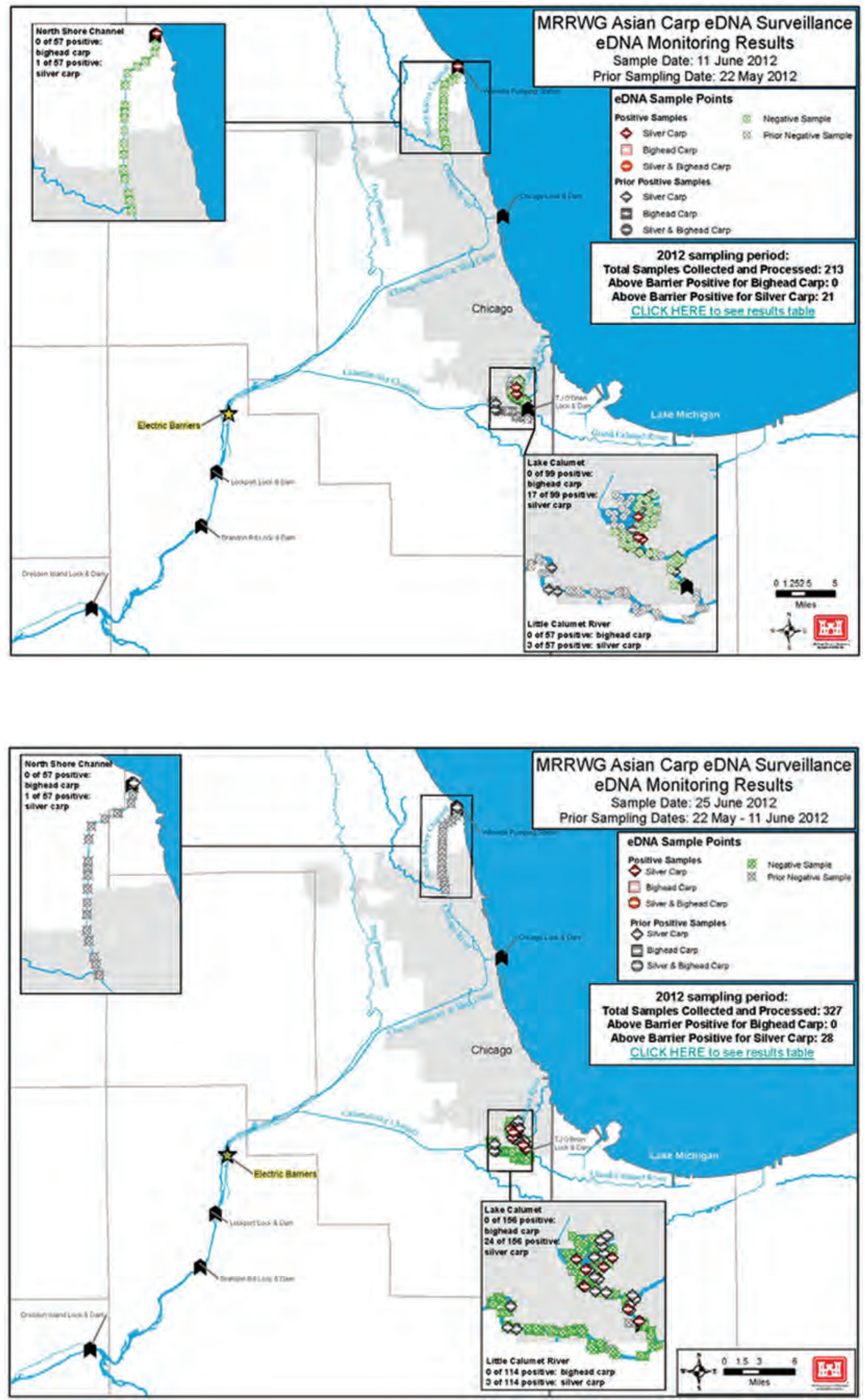


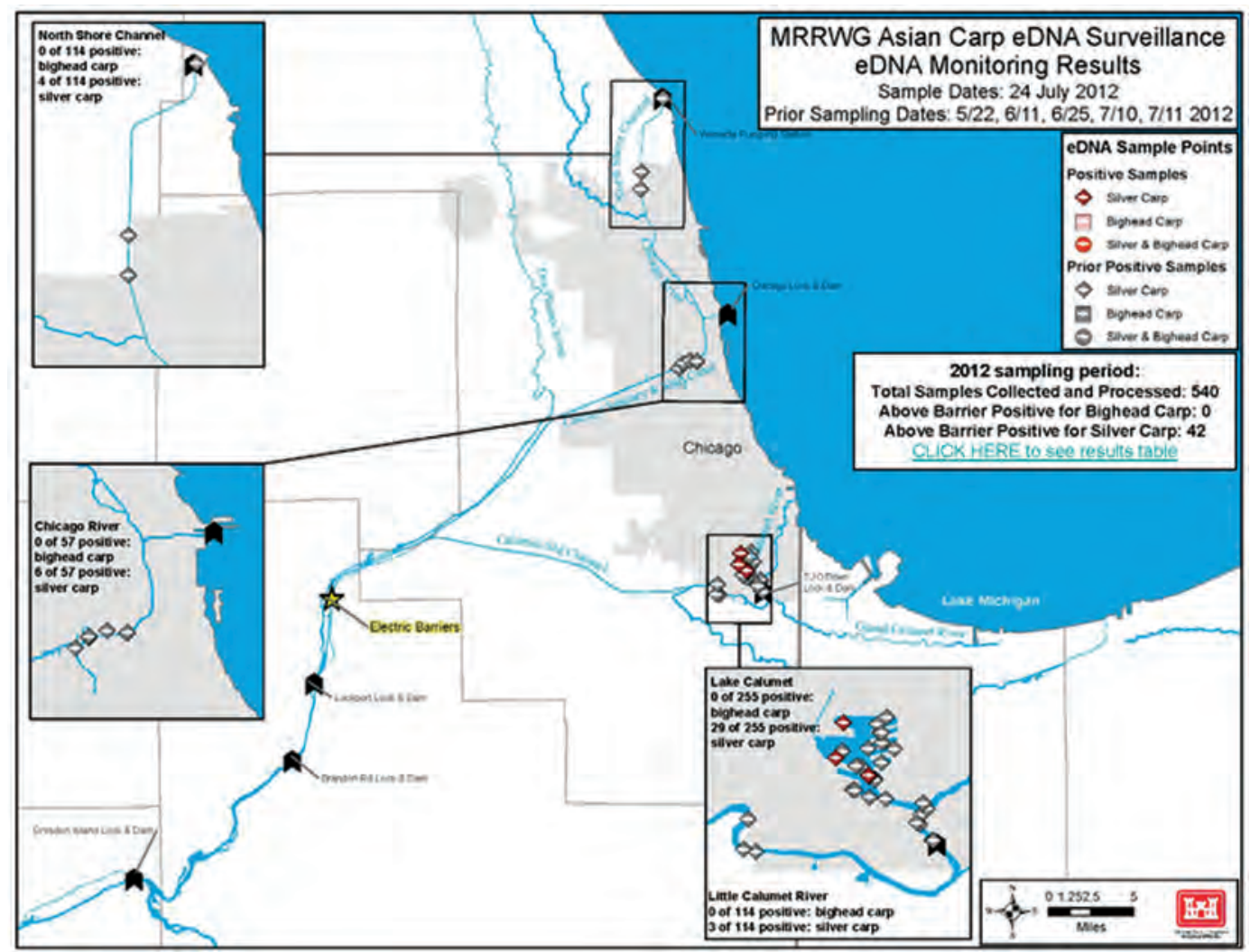


Appendix 2. Map, Profiles, and Cross Sections of the Main Drainage Channel of the Chicago Sanitary and Ship Canal, from Chicago to Joliet, Illinois (modified from Hill, 1896)

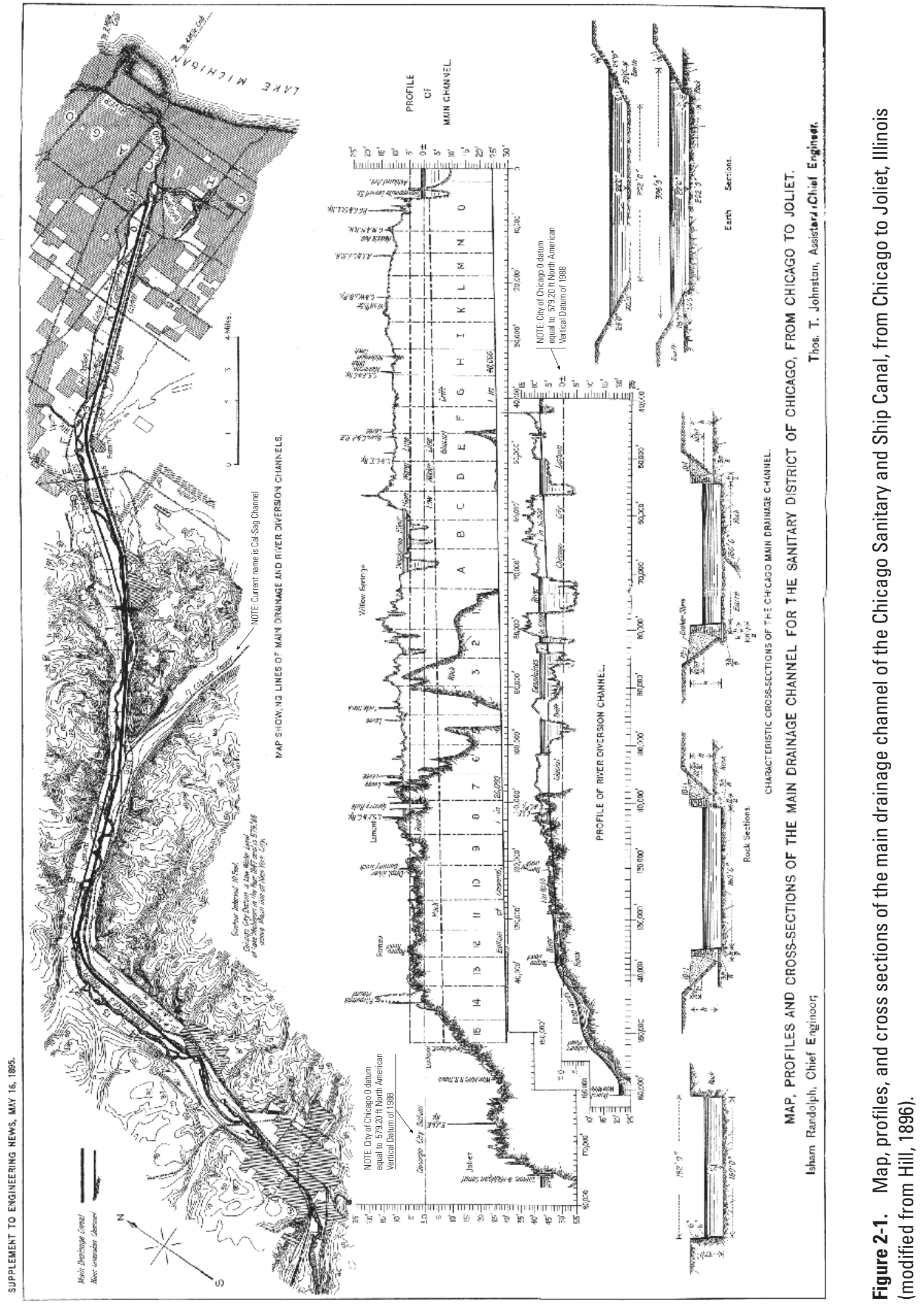




\section{Appendix 3. Methods of Data Collection and Analysis}

Various methods were used to characterize the geology, hydrology, sediment, and water quality of the Des Plaines River (DPR), Illinois and Michigan Canal (IMC), and Chicago Sanitary and Ship Canal (CSSC) during the investigation. The methods are presented in their approximate order of performance, which is summarized in table 1 in the main body of the report.

\section{High-Resolution Bathymetric Survey}

A bathymetric survey of the CSSC within the area of interest, including the boat slips off of the main channel, was done from February 25 through March 1, 2010, by personnel from the U.S. Geological Survey (USGS) and the University of Illinois at Urbana-Champaign. The purpose of this survey was to better define the minimum altitude at which fractures could feasibly hydraulically interact with the CSSC and to generate high-resolution bathymetric imagery of the walls of the CSSC for fracture characterization.

A RESON SeaBat7125-B multibeam echo sounder (MBES) instrument was used to complete the survey. This MBES is a shallow-water system with vertical resolutions on the order of 0.2-0.4 inches (in.) This MBES is owned and operated by the University of Illinois in cooperation with the USGS Illinois Water Science Center. The 7125-B is a dual 200/400-kilohertz-frequency system with only one sonar receiver and was used to measure the relative water depth across a wide swath perpendicular to the track of the survey vessel. A projector array on the sonar head transmits acoustic pulses into the water column, with reflections from the water column and bed being received on a phased receive array. The SeaBat 7125-B was operated at a ping rate of 25 hertz with 512 beams with a total across-track subtended angle of 128 degrees, permitting a swath width measurement of about 4 to 5 times the effective water depth (generally 100- to 125 -feet (ft) swath width in the CSSC). A combined motion and gyro sensor with inbuilt positioning (an Applanix POS/MV 320) provided full 3D motion and orientation data for MBES data processing, and a Leica 1230 RTK differential global positioning system (dGPS) with CORS GSM RTK outputs both a position (accurate to about $0.8 \mathrm{in}$. in the horizontal) and pulse per second, which was used to synchronize the sensors and remove all temporal latency in the MBES processing setup. The MBES system was mounted on the bow of a 19-ft boat during the survey. Sixteen spatially distributed sound velocity casts were collected during the survey to allow proper correction of the depths for variations in sound velocity with depth during data processing.

The MBES survey was done on the CSSC from Romeo Road to Lake Michigan and north along the North branch of the Chicago River (fig. 1 in main body of report); however, only the data from Romeo Road to about Gilbert Avenue/ South Willow Springs Road (fig. 2 in main body of report) were analyzed for this investigation. The water-surface elevation in the CSSC was approximately $577 \mathrm{ft}$ North American Vertical Datum of 1988 (NAVD 88) at the time of the survey but did vary throughout the survey. Water-surface elevations from five USGS streamgages on the CSSC were used in data processing to transform measured soundings to bed elevations (because of issues with using GPS elevation data). Data were processed with the software package Caris and exported as point cloud data (approximately 450 million soundings) to ensure there was no loss of resolution along the walls of the canal during gridding. Point cloud data were visualized by using both Fleudermaus and ArcScene for fracture identification. Anomalies in the walls of the canal that resembled fractures or fracture clusters were marked as targets during data review. The positions of these targets were then used as a data layer in Geographic Information System (GIS) analysis to determine whether they coincide with observations from other datasets collected for this investigation. In addition to fractures, the MBES data were used to identify locations of sediment mounds in the CSSC.

\section{Surface-Water-Quality Profiling}

Profiles of basic water-quality parameters (temperature, specific conductance, dissolved oxygen, $\mathrm{pH}$, turbidity, and depth) were collected in the CSSC from about Romeo Road to Gilbert Avenue/South Willow Springs Road (fig. 2 in main body of report) during February 25-26, 2010, and March 2-3, 2010. Parameters were measured with a boat-mounted YSI 6920 multiparameter sonde and at a sampling rate of 1 hertz. Data were georeferenced by using a Hemisphere Crescent A100 Smart Antenna dGPS receiver mounted on a mast above the sonde. Surveys on February 25-26, 2010, were completed in conjunction with the MBES survey of the CSSC, with the sonde mounted approximately $1 \mathrm{ft}$ below the water surface, thus yielding water-quality information on the near-surface part of the CSSC. On March 2-3, 2010, the sonde was attached to a 30-pound (lb) Columbus weight and suspended from a cable off a boom on the port side of the survey boat and towed at approximately $9 \mathrm{ft}$ below the surface of the CSSC throughout the survey reach $(9 \mathrm{ft}$ was chosen to ensure clearance above obstructions on the bed). During the towed portion of this survey, the survey vessel paralleled the north bank of the CSSC (the bank adjacent to the DPR) in an attempt to detect any anomalous water-quality distributions that may be associated with inflows of DPR-affected water. In both surveys, the main channel and boat slips were surveyed where accessible, and the surveys included periodic vertical profiles of water quality throughout the water column to document any stratified flow conditions. Both surveys included multiple profiles through the study reach to allow stationary point-source anomalies to be identified and differentiated from water mass 
variations advecting downstream in the canal. Water-quality data collected during this profiling are available to the public in the ScienceBase database (Jackson, 2016a).

\section{Fracture Location and Orientation}

Fractures and potential solution openings above the water surface were described at bedrock exposures along the walls of the CSSC and IMC and on the banks of the DPR during boat reconnaissance trips on March 17 and May 4, 2010. Fractures and potential solution openings in the exposed bedrock surface also were described during a foot survey within the study area between the DPR and CSCC and at the Great Lakes, Consumers, and SAG Quarries (fig. 2 in main body of report). Fracture descriptions included representative measurements of fracture orientations, along with approximated dip angles, apertures, and the spacing between fractures.

At about 90 spatially clustered locations, the orientations of 265 near-vertical fractures were measured by use of a Brunton compass. The results were plotted on a rose diagram by using one unit length per fracture and grouping the fractures in 10 degree sectors.

\section{Streambed Survey of Des Plaines River}

The composition of the materials at the streambed in the DPR was surveyed throughout the study area on March 17, 2010 , to identify areas where migration of particulates into the bedrock from the bottom of the DPR would be possible. For the survey, 1-in.-diameter polyvinyl chloride (PVC) tubing was used to "feel" the bed of the river from a boat platform and to collect a small sediment sample, if possible. The composition of the material at the streambed and the apparent bedsediment thickness were described. Samples typically were collected at about 0.25 mile (mi) intervals. The location of the point of data collection was determined by a handheld GPS. Sediment composition was also compared to visual observations of the streambank material, as well as descriptions of surficial geology mapped during construction of the CSSC (Hill, 1896) (Appendix 2).

The composition of the bed sediment in the IMC was surveyed in a more indirect approach than that of the DPR. Bankside inspections were made during various foot surveys, and imagery from Google EarthTM was reviewed. Foot surveys were done on March 30-31, 2010, and July 31, 2010, and included the majority of the IMC from about the Cal-Sag Channel to about 4 mi downstream of Romeo Road (fig. 2 in main body of report); reaches of about $1.5 \mathrm{mi}$ between Lemont Road and I-355 and about $0.5 \mathrm{mi}$ shortly upstream of Romeo Road were not inspected. Satellite imagery from June 30, 2010, was reviewed of the entire reach from the Cal-Sag Channel to about 4 mi downstream of Romeo Road.

\section{Direct-Current Resistivity Surveys}

Surface direct-current (DC) resistivity surveys were done during June 2010 by USGS personnel from the Illinois, Texas, and Kentucky Water Science Centers at five sites within the study area to identify the presence, location, and orientation of potential fractures in the dolomite bedrock. At site 3, a single profile was completed parallel to the DPR (fig. 3 in main body of report). At sites 2 and 5, one profile was completed parallel to either the DPR or the CSSC, and a second profile was completed between the DPR and the CSSC. At sites 1 and 4, one profile was completed parallel to the DPR, a second profile was completed parallel to the CSSC, and a third profile was completed between the DPR and the CSSC.

An STING R1 Earth Resistivity Meter (Advanced Geosciences, Inc., 2010) was used to collect voltage values across a Wenner-Schlumberger array (an electrode configuration where all electrodes are linearly spaced and the receiving electrodes are placed between the transmitting electrodes). The STING R1 was configured with four sets of multi-conductor cables, each cable having seven electrode terminals at 6 - $\mathrm{ft}$ spacing. Stainless steel electrodes were installed in the ground and connected to electrode terminals built into the multiconductor cables. Each electrode was geospatially referenced with coordinates collected from a real-time kinematic Global Positioning System receiver. The default parameters were used on the STING R1 for data collection, except that the maximum repeat was increased to 2 . A contact resistance check was run before each data collection to ensure that the electrodes were making a good connection with the earth.

The raw apparent-resistivity data were processed and inverted with topographic data by using the finite-element method with the smooth model inversion, or Occam's inversion, by means of an Advanced Geosciences, Inc., EarthImager 2D version 2.4.0 Build 617 (Advanced Geosciences, Inc., 2010). The default surface parameters were used except that the maximum repeat error was increased to 10 percent to account for the locations where contact resistance was higher than 1,000 ohms because bedrock was near the surface. Each profile was optimized to a resistivity value for the starting model instead of using the average apparent resistivity as the starting model. This was done by a trial and error process of selecting a resistivity value for the starting model, running the inversion, and documenting which resistivity returns the lowest percent error for the inversion.

\section{Water-Velocity Monitoring}

Synoptic measurements of water velocity of the CSSC were collected at selected locations identified by other investigative techniques as being areas where groundwater might be recharging to the canal. These measurements were made on December 7, 2010. A 1,200-kiloHertz TRDI Rio Grande acoustic Doppler current profiler was used to map water 
velocities in three dimensions from approximately $1.0 \mathrm{ft}$ below the water surface to approximately $1.5 \mathrm{ft}$ above the bottom of the CSSC. The instrument was configured for water mode 12, with 9.8-in. bins and a 0.83 -second sampling rate. Data were georeferenced by using a Hemisphere Crescent A100 Smart Antenna dGPS receiver (horizontal accuracy approximately $2 \mathrm{ft}$ ). Survey methods included (1) near-bank transects along both banks to capture velocity signatures from possible inflows from the canal walls and (2) transects encompassing suspected inflows to try to quantify total inflow discharge. The Doppler current profiler data are available to the public in the ScienceBase database (Jackson, 2016b).

\section{Well Installation}

Wells ACL-1, WS4-W1, WS4-W2, WP9-275, WP1085, and WP7-205 (figs. 2 and 4 in main body of report) were drilled into the dolomite bedrock for this investigation at locations where fracture analysis, DC-resistivity surveys, watervelocity monitoring, and surface-water-quality profiling on the CSSC indicated fractures might be present in the dolomite. Wells were drilled during December 16-21, 2010, by means of air-rotary and pneumatic hammer techniques. Surface casings for each well were installed to a depth of about $4 \mathrm{ft}$ into competent dolomite and secured with a locked well cap. Low-permeability grout was poured in the annulus between the surface casing and the borehole wall to prevent surface water from entering the well. The wells then were completed as 6-in.-diameter open holes in the dolomite to depths of about 60-70 ft, which corresponds to an altitude of at least $25 \mathrm{ft}$ below the bottom of the CSSC in the area where the monitoring wells were installed (table 3 in main body of report). Wells were developed by surging with air from the drill rig.

Lithologic logs were prepared by USGS personnel, who oversaw the drilling. Lithologic logs identified the lithology encountered at depth as well as the depth of hydraulically active features (or their absence) at the well.

\section{Location and Altitude Surveying}

Surveys to determine the location (latitude and longitude) and altitude of wells, DC-resistivity transects, and surfacewater gages were done with a Trimble 5600 Robotic Total Station and a Trimble R8 GNSS (Global Navigation Satellite System). The GNSS was used with support from Trimble Virtual Reference Station network. Location and altitude datums were North American Datum of 1983 (NAD 83) and NAVD 88, respectively. Altitude values were accurate to within $0.79 \mathrm{in}$. for resistivity transects and $0.39 \mathrm{in}$. for wells and gages. Latitude and longitude values were accurate to within 0.4 in.

\section{Borehole Geophysical Logging}

Natural gamma, 3-arm caliper, fluid temperature, delta fluid temperature, fluid resistivity, spontaneous potential, lateral resistivity, 16-normal resistivity, and 64-normal resistivity borehole geophysical logs were run in each of the wells drilled for this investigation (figs. 2 and 4 in main body of report) and wells FB-201 and FB-534 drilled by the U.S. Army Corps of Engineers (USACE) near the electric fish barrier (depths of 201 and $534 \mathrm{ft}$, respectively) (fig. 2 in main body of report). These logs were run during October and November 2010 and during February 2011 by personnel from the U.S. Environmental Protection Agency, Office of Superfund, Chicago, Illinois, using a Century System VI with USGS assistance.

Borehole camera logs were run in wells WP10-85 and WP9-275, and colloidal borescope logs were run in wells ACL-1, WP10-85, and WP9-275 in February 2011 by personnel from the USGS Indiana Water Science Center. The borescope log measures the velocity of colloidal particles at depth within a well, allowing the groundwater direction and velocity at that depth to be determined. Camera logging was attempted in well ACL-1 but could not be completed because of the high turbidity in the well.

\section{Aquifer Testing}

Horizontal hydraulic conductivity $\left(K_{h}\right)$ of the dolomite deposits was calculated by using data collected from slug tests in wells WS4-W1 and WS4-W2 as well as in test intervals isolated by use of packer assembly over the entire saturated thickness of wells ACL-1, WP10-85, and WP9-275 (fig. 4 in main body of report). The methods of data collection and analysis, as well as the $K_{h}$ values calculated, were reviewed and approved by the USGS. General procedures for the slug testing using a packer assembly are presented in Mills (1993). The data collection, data compilation, assumptions about aquifer conditions, analytical methods, and $K_{h}$ calculations pertaining to the aquifer testing performed for this investigation are available from the authors by request.

Slug tests involved instantaneous raising of the water level in the well by insertion of a solid PVC cylinder into the water column and measurement of water-level decline with time. Once water levels had returned to (or very near), hydrostatic levels, the PVC cylinder was removed from the water column, and water-level rise through time was measured. Water levels were measured on a logarithmic time scale by use of a calibrated 0 - to 15 -pounds per square inch $\left(\mathrm{lb} / \mathrm{in}^{2}\right)$ pressure transducer connected to a datalogger. A minimum of two tests were done in each well or packed interval, and the average value of all of the tests in a given test interval was reported.

Data from many of the slug tests displayed a continuous decline in water levels through time and were analyzed using the technique of Bouwer and Rice (1976); this technique was 
developed for use in unconfined aquifers with wells that fully or partially penetrate an aquifer. Water levels from some of the slug tests exhibited an oscillatory response, which was analyzed using the van der Kamp (1976) technique; this technique was developed for analysis of slug-test data from highly permeable aquifers in which the effects of inertia of water in the well dominate the aquifer response (underdamped case). A fully penetrating well in a confined aquifer is assumed for this technique. The aquifer storage coefficient was assumed to be 0.001 when aquifer transmissivity was calculated. This storage coefficient is probably representative of confined conditions where the water level is above the well screen. The thickness of the aquifer was assumed to be equal to the saturated length of the well screen when $K_{h}$ was calculated from the transmissivity values.

\section{Water-Level Monitoring}

Surface-water levels were monitored on a 15-minute frequency at USGS gage 05533600 on the DPR and on a 10-minute frequency at gage 05536890 on the CSSC from April 1 through November 30, 2011 (fig. 2 in main body of report). Groundwater levels also were monitored on a 15-minute frequency in wells WS4-W1, WS4-W2, WP10-85, and ACL-1 during at least part of this period (fig. 4 in main body of report). These data were collected to characterize the interaction between the DPR, the CSSC, and the groundwater system.

Water levels were collected by use of pressure transducers and dataloggers. The accuracy of the transducer measurements in the wells was checked by comparison to periodic manual measurements of depth to water collected by use of an electric water-level indicator calibrated to $0.01 \mathrm{ft}$. Manual measurements typically were recorded relative to land surface and repeated to ensure accuracy. The accuracy of the transducer measurements at the surface-water gages was checked by comparison to periodic stage readings collected by use of a wire-weight gage (gage 05533600) or a staff gage (0556890), both of which are calibrated to $0.01 \mathrm{ft}$.

Single measurements of depth to water also were collected above, within, and below test intervals isolated by use of a packer assembly in wells WP10-85, WP9-275, and ACL-1 during February 2011. Water levels were collected from the wells prior to packer inflation and from the test intervals periodically after packer inflation until water levels in each part of the test interval had approximately stabilized. Water levels were collected manually by use of an electric water-level indicator.

In addition, periodic synoptic measurements of water levels in wells WS4-W1, WS4-W2, ACL-1, WP10-85, and WP9-275 were collected manually by use of an electric waterlevel indicator from February 14 through November 14, 2011. Measurements on a given date typically were collected within an 8-hour period.

\section{Water-Quality Monitoring}

Water-quality monitoring was completed to help characterize the interaction between the DPR, CSSC, and the groundwater system. Temperature, specific conductance, turbidity, and concentrations of dissolved oxygen were monitored for this investigation on a 15-minute frequency at USGS gage 05533600 on the DPR and gage 05536890 on the CSSC (fig. 2 in main body of report) during most of the period from April 1 through November 30, 2011. Water-quality data were measured and stored by use of a YSI 6920-V2-2 sonde equipped with a YSI 6150 ROX optical dissolved oxygen sensor, a YSI 6136 turbidity sensor, and a YSI 6560 conductivity and temperature sensor. Raw data were manipulated, where necessary, to compensate for drift in the readings.

Temperature, specific conductance, or dissolved oxygen were monitored on a 15-minute frequency in wells WS4-W1, WS4-W2, WP10-85, and ACL-1 (fig. 4 in main body of report) during at least part of the period from April 1 through November 15, 2011. Water-quality data were measured and stored by use of a YSI 600OMS V2 sonde equipped with a YSI 6150 ROX optical dissolved oxygen sensor or YSI 6136 turbidity sensor and a YSI 6560 conductivity and temperature sensor or by use of an In-Situ Aqua TROLL 200.

Data collection, including sensor maintenance and calibration, was in accordance with USGS standard procedures (Wagner and others, 2006). Sensors, except temperature, were calibrated approximately monthly.

A water sample was collected from well WP10-85 on February 2, 2012, and analyzed for major ions. The sample was collected by use of a peristaltic pump, with the water intake set to the elevation of the fracture in the well. Analyses were done by the USGS National Water Quality Laboratory in Denver, Colorado.

\section{Dye Tracer Study}

A dye-tracer study was done by USGS personnel on the DPR and the nearby wetlands, groundwater, and CSSC during November 14-29, 2011. Although particulates such as carp eggs would not be transported in precisely the same way as dissolved dye, the dye tracer was used to determine the potential for water movement from the DPR, through the groundwater system, into the CSSC; to identify where this movement was occurring; and to determine the amount of time required for this movement to occur.

A calibrated dye injection system with redundant fluid-metering pumps was used to continuously deliver dye from injection tubing at three locations approximately one-fourth, one-half, and three-fourths of the width of the DPR channel at a flow rate of 17.9 gallons per day (gal/d) at each injection point (total $53.7 \mathrm{gal} / \mathrm{d}$ ). Injection was done at three locations to help ensure even distribution of the tracer in the river. Injection began at 1050 hours on November 15, 2011, and ended at 1200 hours on November 16. A total of 
approximately 57 gallons of rhodamine WT in a 20 percent solution was used in the study. The injection site was on the DPR near the northern edge of the study area (fig. 5 in main body of report) and was chosen for ease of river access and to ensure the tracer was well mixed across the river by the time it migrated to the focus area between Lemont Road and I-355.

Dye concentrations were measured every 3 or 10 minutes by means of Turner Designs C-3 and C-6 fluorometers with internal dataloggers at three fixed locations on the DPR (DP1, DP-2, and DP-3); in three groundwater monitoring wells (ACL-1, WP10-85, and WP9-275); and at two fixed locations on the CSSC (SC-1 and SC-2) (fig. 5, table 2 in main body of report). The detection limit for these fluorometers is reported to be 0.01 micrograms per liter $(\mu \mathrm{g} / \mathrm{L})$ (http://www.turnerdesigns.com/products/submersible-fluorometer/c3-submersiblefluorometer, accessed November 29, 2012). However, the fluorometer readings were affected by turbidity (fig. 32 in main body of report), and readings of less than about $1.0 \mu \mathrm{g} / \mathrm{L}$ were considered to have been influenced by turbidity and variability in background fluorescence rather than indicative of the detection of dye.

Measurements began prior to the arrival of dye at all locations (to ensure background concentrations were properly documented) and continued for 3-13 days after tracer injection ceased, depending on the location. Fluorometers were calibrated the day prior to the start of the study by using water from the site where the fluorometer was to be deployed to make the final dilution of the calibration solution. Fluorometers installed in the wells were deployed at the depths of hydraulically active fractures in each well. The fluorometer installed in the CSSC at the bottom of the ACL-1 slip (SC-2) was mounted to a weighted frame and deployed adjacent to the canal wall near a potential hydraulically active fracture on the canal wall. The fluorometer placed upstream in the CSSC (SC-1) was a C-6 fluorometer, and it was deployed at USGS gage 05536890 at a depth of approximately $10 \mathrm{ft}$ below the water surface in an attempt to document any dye infiltration upstream of this site.

In addition to the measurements at fixed stations, a survey boat equipped with differential GPS (Hemisphere Crescent A100 Smart Antenna) and a Turner Designs C3 submersible fluorometer was used to survey the spatial distribution of the dye in the CSSC throughout the study area. The fluorometer was installed in a fixed, downlooking orientation approximately $1 \mathrm{ft}$ below the water surface. Fluorometer readings were taken at a frequency of 1 per second. Data were acquired on a personal computer running the Turner Designs CFINS software extension for ArcGIS 10. This data acquisition software allows the $\mathrm{C} 3$ data to be georeferenced and plotted in real time as color-coded concentrations on a user-supplied base map. The data were logged in the CFINS program and stored as shape-files, and raw (ungeoreferenced) data were stored internally on the boat-mounted $\mathrm{C} 3$ and downloaded at the end of each shift (every 12 hours). Survey techniques were restricted to streamwise transects along the bank of the CSSC nearest the DPR in both the upstream and downstream direction. The boat survey crew followed the wall of the canal as closely as possible, including data collection in barge slips. Mooring of barges and active barge traffic restricted surveys in some locations and led to some contamination of fluorometer data by increasing local turbidity concentrations near the active vessels (fig. 32 in main body of report). Several vertical profiles were also made in target areas to ensure dye was not being transported near the bed without any surface detection. Dye concentration data collected in the CSSC during the tracer study are available to the public in the ScienceBase database (Jackson, 2016c).

A YSI 6920 sonde with 6130 submersible fluorometer was used to supplement the fixed-station fluorometer readings in the DPR and to survey the spatial distribution of dye in the channel of the DPR at DP-1 and DP-2. Additionally, this sonde was used to collect twice-daily depth and areal profiles of tracer concentration along the wall of the CSSC at the boat slip near well ACL-1.

Discrete grab samples of surface water and groundwater were periodically collected by use of a peristaltic pump at the fluorometer locations throughout the duration of the testincluding prior to tracer injection. The intake point for the polyethylene tubing that transmitted water to the pumps was taped to the base of the fluorometers deployed in the wells to ensure that comparable samples were collected. Samples in the DRP were collected near the middle of the channel. In addition, grab samples of water were collected from the wetlands between the DPR and the CSSC (WT locations in fig. 5 in main body of report). Dye concentrations in these grab samples were measured by a Turner Designs Model $10-\mathrm{AU}$ fluorometer to verify the concentrations measured by the fixed-station fluorometers and to supplement the area of data availability. 


\section{References Cited}

Advanced Geosciences, Inc., 2006, Instruction manual for EarthImager 2D version 2.1.0-Resistivity and IP inversion software: Austin, Tex., accessed November 1, 2006, at http://www.agiusa.com/files/pub/softwareproducts.shtml.

Bouwer, Herman, and Rice, R.C., 1976, A slug test for determining hydraulic conductivity of unconfined aquifers with completely or partially penetrating wells: Water Resources Research, v. 12, no. 3, p. 423-428.

Hill, C.S., 1896, The Chicago main drainage channel: New York, Engineering News Publishing Co., 129 p.

Jackson, P.R., 2016a, Water-quality distribution in the Chicago Sanitary and Ship Canal, USGS towed multiparameter sonde, Daily tow data files (Feb. 25-27, 2010 and March 2-3, 2010): U.S. Geological Survey data release, http:// dx.doi.org/10.5066/F7N877WG.

Jackson, P.R., 2016b, Acoustic Doppler current profiler velocity data collected in the Chicago Sanitary and Ship Canal in 2010 and 2011 in support of the interbasin transport study for invasive Asian carp: U.S. Geological Survey data release, http://dx.doi.org/10.5066/F7S180KR.

Jackson, P.R., 2016c, Spatial distribution of Rhodamine WT dye concentration measured in the Des Plaines River and the Chicago Sanitary and Ship Canal, Chicago, IL in November 2011: U.S. Geological Survey data release, http://dx.doi.org/10.5066/F7HH6H55.

Mills, P.C., 1993, Hydrogeology and water quality of the Galena-Platteville aquifer at the Parson's Casket Hardware Superfund site, Belvidere, Illinois, 1991: U.S. Geological Survey Open-File Report 93-403, p. 12-14.

van der Kamp, Garth, 1976, Determining aquifer transmissivity by means of well response tests - The underdamped case: Water Resources Research, v. 12, no. 1, p. 71-77.

Wagner, R.J., Boulger, R.W., Oblinger, C.J., and Smith, B.A., 2006, Guidelines and standard procedures for continuous water-quality monitors - Station operation, record computation, and data reporting: U.S. Geological Survey Techniques and Methods 1-D3 [variously paginated]. 
Geology, Hydrology, Water Quality, and Potential for Interbasin Invasive-Species Spread Near Lemont, Illinois

\section{Appendix 4. Detailed Geologic Assessment of the Bedrock Deposits}

The bedrock deposits of concern to this investigation are dolomite of Silurian age consisting of the Joliet, Sugar Run, and Racine Formations (fig. 6 in main body of report). Because the area of concern is along the crest and the eastern flank of the Kankakee Arch (Willman, 1971), these strata dip slightly to the east and southeast because of the eastward plunge of the arch. As a result, the Silurian deposits generally decrease in age and increase in thickness from southwest to northeast (figs. 4-1, 4-2). Differential erosion of the bedrock surface is superimposed on this trend, affecting the location of the bedrock deposits. Older units are present further to the east in the vicinity of the more eroded, topographically low Des Plaines River (DPR), Chicago Sanitary and Ship Canal (CSSC), and Illinois and Michigan Canal (IMC). Younger units are present further to the west in the less eroded, topographically higher areas away from these surface-water bodies.

Wells drilled in and near the study area for this and previous investigations penetrate a distinctive red dolomite and shale which is part of the Brandon Bridge Member of the Joliet Formation (fig. 6 in main body of report, fig. 4-2) (Willman and others, 1975). The elevation of the top of this deposit is about 10 feet (ft) below that of the bottom of the CSSC between Lemont and Romeo Roads. Because of its proximity to the bottom of the CSSC, the Brandon Bridge Member is the deepest stratigraphic unit of concern to this investigation. The Brandon Bridge Member is overlain by the Markgraf and Romeo Members of the Joliet Formation at wells FB-201 and WP7-205 and a small thickness of the Sugar Run Formation at the wells installed in the focus area (ACL-1, WP10-85, WP9-275, and WS4-W1) (figs. 4-1, 4-2, 4-3).

North of Lemont Road, the Sugar Run Formation thickens and is increasingly exposed along the walls of the CSSC. At the Consumers Quarry, the Sugar Run Formation appears to be about $10 \mathrm{ft}$ thick and constitutes the uppermost bedrock deposit (figs. 4-1 through 4-3) (Donald Mikulic, Illinois State Geological Survey, oral commun., 2010). At the Great Lakes Quarries approximately $0.25-0.75$ miles (mi) to the east, the Sugar Run Formation is overlain by approximately $20 \mathrm{ft}$ of Racine Formation, which is the uppermost bedrock deposit extending east through the area of interest (fig. 4-3).

Given the dip in these strata (about 15 feet per mile), the thickness of the Racine Formation deposits at the Great Lakes Quarries is anomalous, particularly when the thickness of the underlying Sugar Run Formation at this location may be as much as $30 \mathrm{ft}$. An escarpment exhibiting vertical displacement features was observed at the former location of the DPR in this approximate area (Bannister, 1868), indicating that faulting may be the cause of this anomalous thickness.

\section{Secondary-permeability Network}

The secondary-permeability network in the dolomite deposits within the area of interest includes vertical and inclined fractures (referred to as "vertical fractures" in this report) (fig. 7 in main body of report) as well as sub-horizontal fractures (referred to as "horizontal fractures" in this report), joints, solution openings, and perhaps a vertical fault. Singly or in combination, these secondary-permeability features are potential conduits for movement of Asian carps and other invasive species, so their location, orientation, and extent within the study area need to be characterized.

The presence of large, areally extensive secondarypermeability features in the bedrock deposits is well documented (see front cover). Fractures in the bedrock are large enough - and extensive enough - to provide water supply to several commercial and municipal entities near the area of interest. Zeizel and others (1962) reported solution cavities "tens of feet in dimension" at a location near the DPR in southwest DuPage County. Marge Bynoe (Argonne National Laboratory, written commun., 1982) described large volumes of water flow attributed to drainage from a solution cavity in the dolomite at Argonne National Laboratory (fig. 2 in main body of report). Rock cores collected by the U.S. Army Corp of Engineers (USACE) during construction of the Cal-Sag Channel and for environmental investigations within the area of interest indicate the presence of horizontal bedding-plane fractures with apertures as large as $2 \mathrm{ft}$ (Nicholas and Healy, 1988; Environmental Resources Management-North Central, 1990, 1992a,b; KPRG and Associates Inc., 2004).

\section{Horizontal Fractures}

Horizontal fractures in dolomite deposits are often the result of solution openings that have developed through geologic time as a result of the concentration of water movement, and rock dissolution, along lithologic boundaries. It is important, therefore, to consider the potential role of lithology in the development of horizontal fractures within the study area.

The purity of the deposits and thick-bedded to massive character of the Romeo Member of the Joliet Formation is likely to inhibit development of solution-related fractures (fig. 6 in main body of report). However, an extensive chert horizon that occurs in the middle part of the Romeo Member might affect dissolution of the adjacent deposits. The argillaceous deposits in the Brandon Bridge and Markgraf Members of the formation also could impede vertical water movement and contribute to secondary dissolution along bedding planes.

The Sugar Run Formation, with its well-bedded, even texture and dense character, is not likely to be strongly conducive to the development of secondary solution features. However, the upper part of these deposits may have thin but prominent argillaceous partings that might contribute to limited to moderate secondary dissolution. 


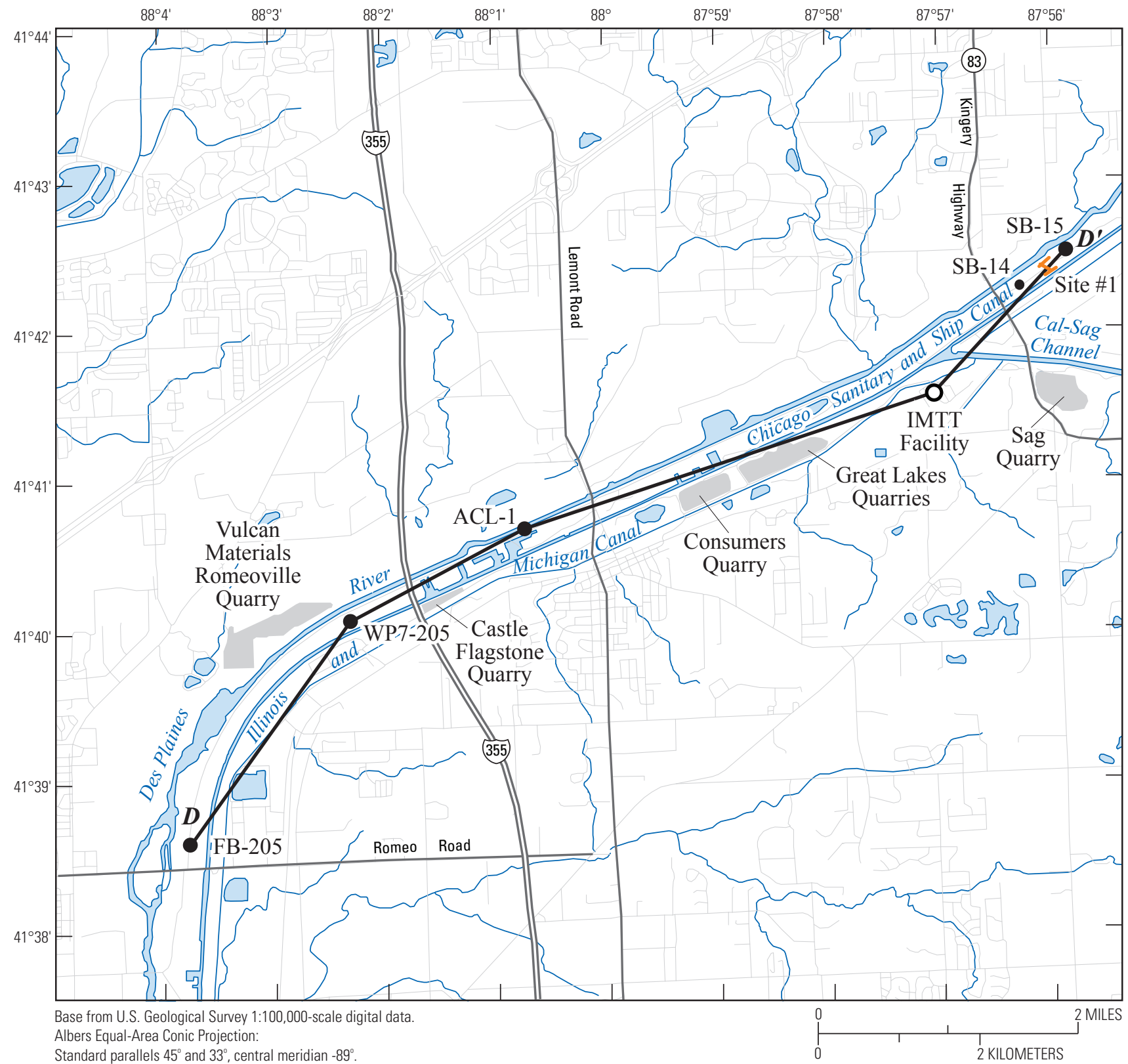

EXPLANATION

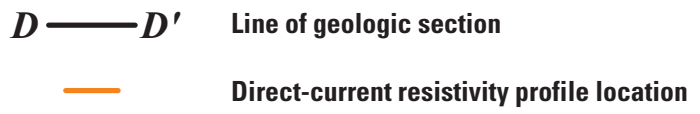

ACL-1 Well location and identifier

Figure 4-1. Line of geologic section D-D' and points of geologic interest near Lemont, Illinois. 


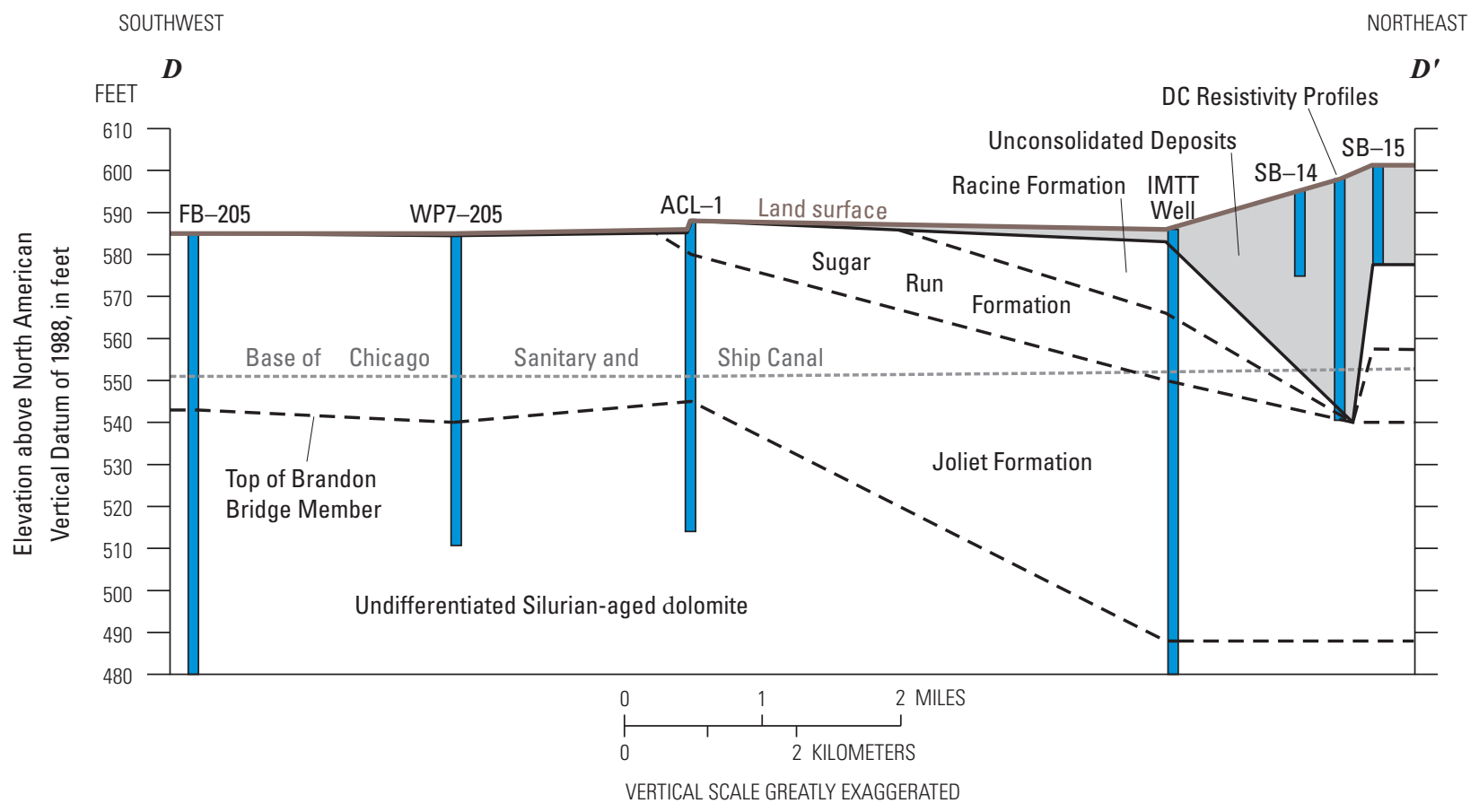

Figure 4-2. Generalized geologic section D-D' near Lemont, Illinois (line of section shown in figure 4-1).

The argillaceous inter-reef deposits that compose parts of the Racine Formation contribute to their high susceptibility to secondary dissolution. The impedance to vertical flow of water caused by argillaceous partings and thin dolomitic shales in the unit likely contribute to the strongly enhanced and widely extensive solution observed along bedding planes in this deposit. Additionally, a cherty horizon that occurs near the base of the unit can affect solution of the adjacent bed deposits because this horizon can be rubbly and, thus, relatively permeable.

Previous investigators (Nicholas and Healy, 1988; KPRG and Associates Inc., 2004) identified several "sub-regional to regional" horizontal fractures at elevations of about 525, 550, 565, and $577 \mathrm{ft}$ North American Vertical Datum of 1988 (NAVD 88) along bedding planes within the Racine and (possibly) the upper part of the Sugar Run Formations at the Red Gate Woods site and at about 561, 570, and $575 \mathrm{ft}$ near the IMTT facility (fig. 2). The fractures can extend hundreds of feet in outcrops along the northern side of the DPR valley and may be continuous for more than a quarter mile.

Because the elevation of the bottom of the CSSC in the area of interest is about 551 to $554 \mathrm{ft}$ NAVD 88, the horizontal fractures in the Racine Formation between about 550 and $577 \mathrm{ft}$ are of special concern to assessing the potential for interbasin transfer by way of the groundwater pathway. These fractures are at the proper elevation to intersect the walls of the CSSC near the Red Gate Woods and IMTT sites and could be extensive enough to also intercept the DPR, or to intercept vertical fractures or solution openings that intercept the DPR.
However, the preponderance of the data collected for this investigation indicate that these fractures are absent from part or all of the area between the DPR and CSSC within the study area due to a combination of factors:

1. The Racine Formation is absent from the topographic lowlands near the DPR and CSSC in the western half of the study area (fig. 4-3).

2. The MBES surveys did not indicate a substantial (greater than 1.2-inches) horizontal fracture near the bottom of the CSSC (near $550 \mathrm{ft}$ ) or at $565 \mathrm{ft}$ along the CSSC in the area near Red Gate Woods or elsewhere within the study area. The other regional fracture that is at the proper elevation $(575 \mathrm{ft})$ to intercept the CSSC could not be observed by the MBES because it was above the maximum height the MBES could measure on the CSSC wall (about $571 \mathrm{ft}$ ). The MBES could not measure above about $571 \mathrm{ft}$ because the elevation of the water surface on the CSSC (about $577 \mathrm{ft}$ ) combined with the 120-degree swath angle of the MBES precluded shallower measurement. Therefore, the presence of a fracture intercepting the wall of the CSSC at $571 \mathrm{ft}$ cannot be discounted.

3. The elevation of the bedrock surface (fig. 8 in main body of report) indicates that these fractures have been removed by paleoerosion along the DPR in most of the area of interest east of DC-resistivity survey site 2. From Romeo Road to about the western part of 


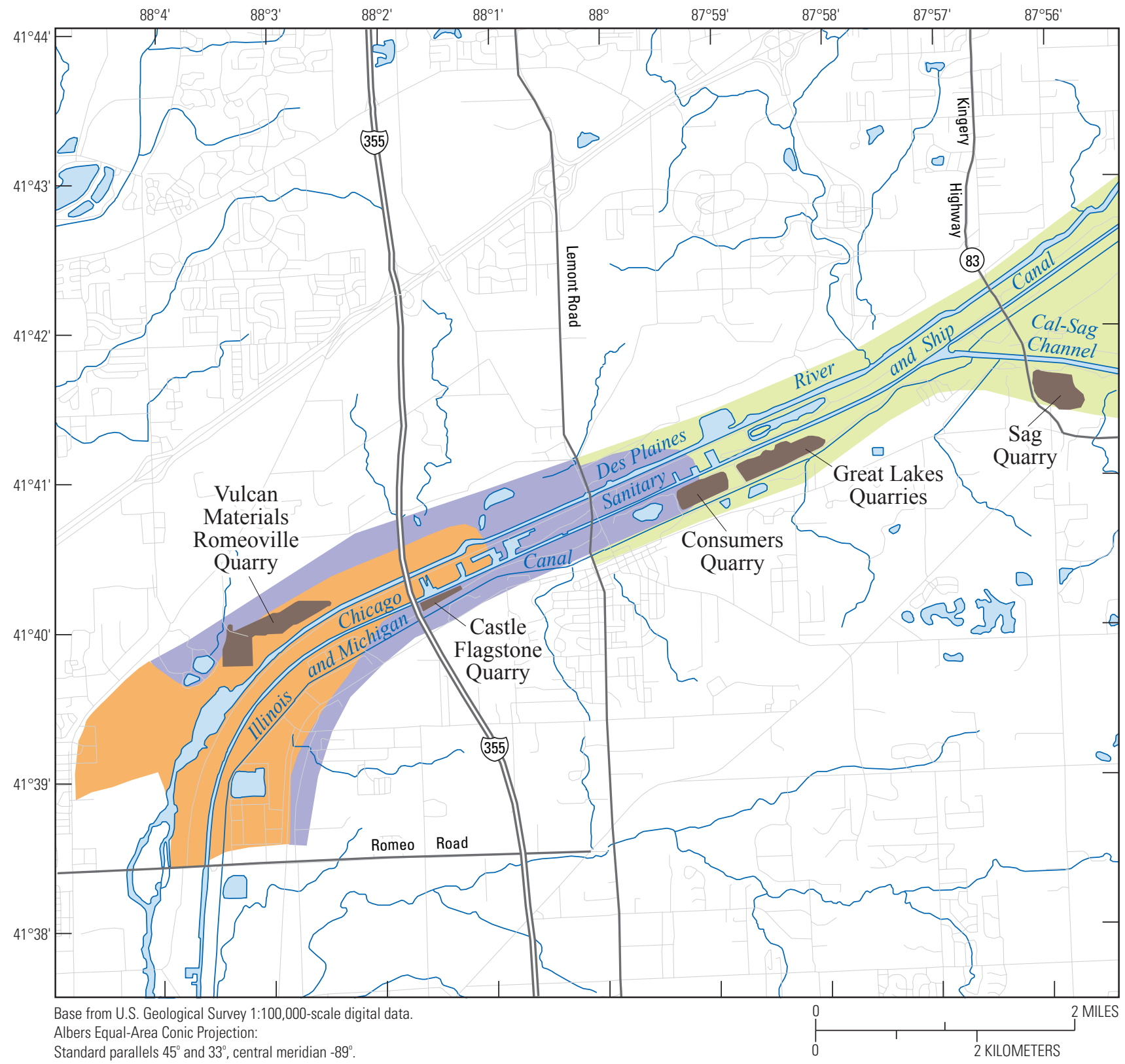

EXPLANATION

Surficial bedrock geology

Racine Formation

Sugar Run Formation

Joliet Formation

Figure 4-3. Surficial bedrock geology in the vicinity of the Chicago Sanitary and Ship Canal near Lemont, Illinois (modified from Vierling, 2001). 
DC-resistivity survey site 2, the elevation of the bedrock surface between the DPR and the CSSC exceeds $580 \mathrm{ft}$ NAVD 88 (appendix 2) but is about 2-6 ft lower near the DPR. From survey site 2 to the area near the confluence with the Cal-Sag Channel, the bedrock surface varies from about 550 to $583 \mathrm{ft}$ NAVD 88 and is about $11 \mathrm{ft}$ lower near the DPR. The elevation of the bedrock surface increases to more than $580 \mathrm{ft}$ west of Kingery Highway. From Kingery Highway east to the area of DC-resistivity survey site 1, the bedrock surface at the CSSC is consistently about $540 \mathrm{ft}$ along the DPR but varies from about 540 to $570 \mathrm{ft}$ near the CSSC at DC-resistivity survey site 1 . The bedrock surface at the CSSC decreases east of survey site 1 and is below the bottom of the CSSC from about Gilbert Avenue east through the rest of the area of interest (fig. 2 in main body of report).

Further characterization of horizontal fracture networks within the study area was done by using DC-resistivity surveys, in addition to field surveys and lithologic and geophysical logging of wells. These data indicate that substantial horizontal fractures are absent from the bedrock between the CSSC and the DPR, except at DC-resistivity survey site 4 (fig. 3 in main body of report).

At site 4, potential horizontal fractures are indicated near the DPR in the southern part of cross section A- $\mathrm{A}^{\prime}$ (figs. 3 and 9 in main body of report) below about $550 \mathrm{ft}$ and potentially extending to the CSSC at about 563-571 ft (figs. 3 and 9 in main body of report). Site 4 also is near the area where field surveys identified a horizontal fracture along the wall of the CSSC at $578 \mathrm{ft}$ NAVD 88 (fig. 7B in main body of report). However, lithologic and geophysical logging from the wells near site 4 indicates that the only fracture in this area is the thin (aperture less than 0.20 inches) horizontal fracture present between about 545 and $552 \mathrm{ft} \mathrm{NAVD} 88$ at wells ACL-1, WP9-275, and WP10-85 (figure 4 and table 3 in main body of report). This fracture is within the Joliet Formation. The location of the fracture bears no obvious relation to a lithologic change in the dolomite, and no fractures were identified in nearby wells WS4-W1 and WS4-W2. Because the elevation of the fracture is similar to the elevation of the bottom of the CSSC (about $551 \mathrm{ft} \mathrm{NAVD} \mathrm{88),} \mathrm{and} \mathrm{because} \mathrm{the} \mathrm{fracture} \mathrm{is}$ present only in the wells within about $55 \mathrm{ft}$ of the CSSC, the fracture may have resulted from construction of the CSSC. Regardless of its origin, the fracture does not extend from the CSSC to the DPR. For Asian carps to move from the DPR to the CSSC through the fracture, it may need to intersect vertical fractures that also intersect the DPR.

\section{Vertical Fractures}

An orthogonal set of vertical fractures was indicated in the dolomite of the Racine Formation at the Vulcan Materials Quarry in McCook (fig. 1 in main body of report), with primary fracture orientations of N. $48^{\circ}$ E. and a secondary orientation of N. $46^{\circ}$ W. (U.S. Army Corps of Engineers, 1999). A third fracture set oriented about N. $15^{\circ} \mathrm{W}$. also was indicated. Fracture spacings of the first set were 1 per $2-10 \mathrm{ft}$; spacings for the second set were about 1 per $10-50 \mathrm{ft}$. The spacings of both sets were indicated to be highly variable, with gaps between fractures of up to $500 \mathrm{ft}$. The northeastward trending fractures were described as normally tight but more likely to contain water than the fractures with a northwest trend, which were described as normally dry and often filled with clay, particularly near land surface. Other assessments of fracture orientations in area of interest also indicate two predominant near-vertical fracture sets with orientations similar to those at the McCook Quarry near the McCook Reservoir (range N. $26^{\circ}$ E. to N. $65^{\circ}$ E. and N. $62^{\circ}$ W. to N. $35^{\circ}$ W.), the Red Gate Woods site (mean orientation N. $40^{\circ}$ E. and N. $50^{\circ} \mathrm{W}$.), and at the former Castle Flagstone Quarry (mean orientation N. $37^{\circ}$ E. and N. $65^{\circ} \mathrm{W}$ ) (Foote, 1982; Nicholas and Healy, 1988; STS Consultants, Ltd., 2002). These orientations are also similar to the mean orientation of 265 vertical fractures measured during this investigation along the walls of the CSSC, IMC, and DPR and in several of the quarries in the study area $-\mathrm{N} .35^{\circ} \mathrm{E}$. with a secondary orientation of N. $65^{\circ} \mathrm{W}$. Because the DPR, IMC, and CSSC have a northeast-southwest orientation within most of the area of interest, the northwest-trending fractures would be the most likely conduits for invasive-species movement because they would be the shortest, most direct transfer route.

Field and MBES surveys from for this investigation indicate that approximately 150 observed and potential vertical fractures were located along the walls of the CSSC (figs. 10A-H in main body of report). These fractures were present from about the Red Gate Woods site to Romeo Road but were most numerous between about Romeo and Lemont Roads. The field surveys indicate that the bedrock exposed at that land surface between the IMC, CSSC, and DPR and the bedrock exposed in outcrops along the DPR (bedrock was about $2 \mathrm{ft}$ above the water line at the time of the field survey) contained vertical fractures that had no measureable aperture. Most of the vertical fractures identified at bedrock exposures along the walls of the CSSC and IMC also had no measureable aperture. Five vertical fractures with measurable apertures (a few inches to about $10 \mathrm{ft}$ ) were observed along the walls of the CSSC and IMC near Romeo Road (figs. 10B and 11 in main body of report), where they are excavated into the Joliet Formation, Romeo Member. However, these large, open vertical fractures appear to close up completely within $10 \mathrm{ft}$ of the walls of the IMC and CSSC.

Many of the large, open vertical fractures seem to be associated with paleokarst sinkholes in the dolomite at and near the CSSC. These sinkholes are infilled with Pennsylvanian-age clastics (fig. 11E in main body of report), resulting in minimal or no open space through which particulates (including carp eggs) could move. The large apertures associated with these features along the walls of the CSSC and IMC may be due to erosion of the paleosediment in the fractures that were exposed by canal construction 
(Donald Mikulic, Illinois State Geological Survey, oral commun., 2010). Other large, open vertical fractures terminate in unaltered bedrock just above the water surface (fig. 11D in main body of report), indicating that they may have initially developed along local planes of weakness associated with closed near-vertical fractures in the bedrock and widened as the result of canal construction, which included use of explosives; damage from contact with barges; and erosion and weathering associated with near-surface flow, freeze-thaw cycles, and chemical interaction with the canal water.

The absence of an extensive network of large vertical fractures in the dolomite bedrock between the DPR and the CSSC in the study area is supported by the results of the DC-resistivity surveys and geophysical logging in the monitoring wells (fig. 4 in main body of report). The DC-resistivity surveys identified potential small vertical fractures at survey site 5 and two potential small to large vertical fractures or fracture clusters near the CSSC at survey site 4 (figs. 3 and 9 in main body of report) (Andrew Teeple, U.S. Geological Survey, written commun., 2010). The survey data indicate these fractures may have penetrated to depths of as much as $100 \mathrm{ft}$ and have spacing in excess of $100 \mathrm{ft}$. However, fractures (vertical or horizontal) were not encountered during geophysical logging in wells WP7-205, WP4-W1, and WP4-W2, which were located to intercept the vertical fractures indicated by the DC-resistivity surveys. Vertical features also were not indicated (horizontal fractures were) during geophysical logging in wells ACL-1, WP10-85, and WP9-275, which are near the CSSC at survey site 4 (fig. 4 in main body of report). Vertical features were not indicated at DC-resistivity survey sites 1,2 , and 3.

Closed fractures with no aperture, large fractures infilled with clastic particles, and fractures associated with canal construction are likely to be incapable of transmitting particulates such as carp eggs between the DPR or IMC and the CSSC, either alone or in combination with horizontal fractures. Most or all of the vertical fractures identified in the study area do not appear to be substantial pathways for invasive-species transfer. However, the existence of such a pathway, particularly below the water line of the CSSC or in areas outside of the DC-resistivity surveys, cannot be ruled out.

\section{Faults}

Stratigraphic evidence suggests the possibility of a fault with notable vertical offset in the vicinity of the Great Lakes Quarries (Bannister, 1868; Donald Mikulic, Illinois State Geological Survey, oral commun., 2010). If present and not infilled with sediment, the fault would likely extend between the DPR, CSSC, and IMC and occur as a zone of rubble, which could act as a conduit for interbasin transfer of Asian carp eggs and fry into the CSSC. However, no fracture or rubble zone across which there was displacement in the rock (the definition of a fault) was observed at the DPR, CSSC, or IMC during field or MBES surveys done for this investigation.

\section{References Cited}

Bannister, H.M., 1868, Geological survey of Illinois, Cook County: Springfield Ill., State Journal Stream Press, v. 3, p. 241-252.

Environmental Resources Management-North Central, 1990, Remedial investigation and feasibility study, Lenz Oil Superfund Site: Prepared for the U.S. EnvironmentalProtection Agency, Chicago, Ill. [variously paginated].

Environmental Resources Management-North Central, Inc., 1992a, Remedial investigation report, Lenz Oil Service, Inc. site, Lemont, Ill.: U.S. Environmental Protection Agency, Project no. 0252 [variously paginated].

Environmental Resources Management-North Central, Inc., 1992b, Technical memorandum no. 3A, remedial investigation, phase 1, task 2, Lenz Oil Services, Inc. site, Lemont, Ill.: U.S. Environmental Protection Agency, Project no. 0252 [variously paginated].

Foote, G.R., 1982, Fracture analysis in northeastern Illinois and northern Michigan: University of Illinois at UrbanaChampaign, M.S. thesis, 193 p.

KPRG and Associates, Inc., 2004, Site investigation and interim remedial objectives report, IMTT, Lemont, Illinois: Prepared for the Illinois Environmental Protection Agency, Springfield, Ill. [variously paginated].

Nicholas J.R., and Healy, R.W., 1988, Tritium migration from a low-level radioactive-waste disposal site near Chicago, Illinois: U.S. Geological Survey Water-Supply Paper 2333, $46 \mathrm{p}$.

STS Consultants, Ltd., 2002, Chicagoland underflow plan, McCook Reservoir, Illinois 50\% review design documentation report-Number 2, groundwater protection system: U.S. Army Corps of Engineers, Chicago District, STS Project 1-27354-ZH [variously paginated].

U.S. Army Corps of Engineers, 1999, Design documentation report, Chicagoland underflow plan, McCook Reservoir, Illinois: Chicago District Civil Design Section [variously paginated].

Vierling, P.E., 2002, A short interpretive treatise of the preglacial geology of the lower Des Plaines River valley in northestern Illinois: Chicago Portage Ledger, 45 p.

Willman, H.B., 1971, Summary of the geology of the Chicago area: Illinois State Geological Survey Circular 460, 77 p.

Willman, H.B.; Atherton, Ellwood; Buschbach, T.C.; Collinson, Charles; Frye, J.C.; Hopkins, M.E.; Lineback, J.A.; and Simon, J.A., 1975, Handbook of Illinois stratigraphy: Illinois State Geological Survey Bulletin 95, 261 p.

Zeizel, A.J., Walton, W.C., Sasman, R.T., and Prickett, T.A., 1962, Ground-water resources of DuPage County, Illinois: Illinois State Geological Survey and Illinois State Water Survey Cooperative Ground-Water Report 2, 103 p. 

Prepared by USGS West Trenton Publishing Service Center.

For additional information, contact:

Director, Illinois Water Science Center

U.S. Geological Survey

405 N Goodwin

Urbana, IL 61801

or visit our Web site at: http://il.water.usgs.gov 


\section{递}

